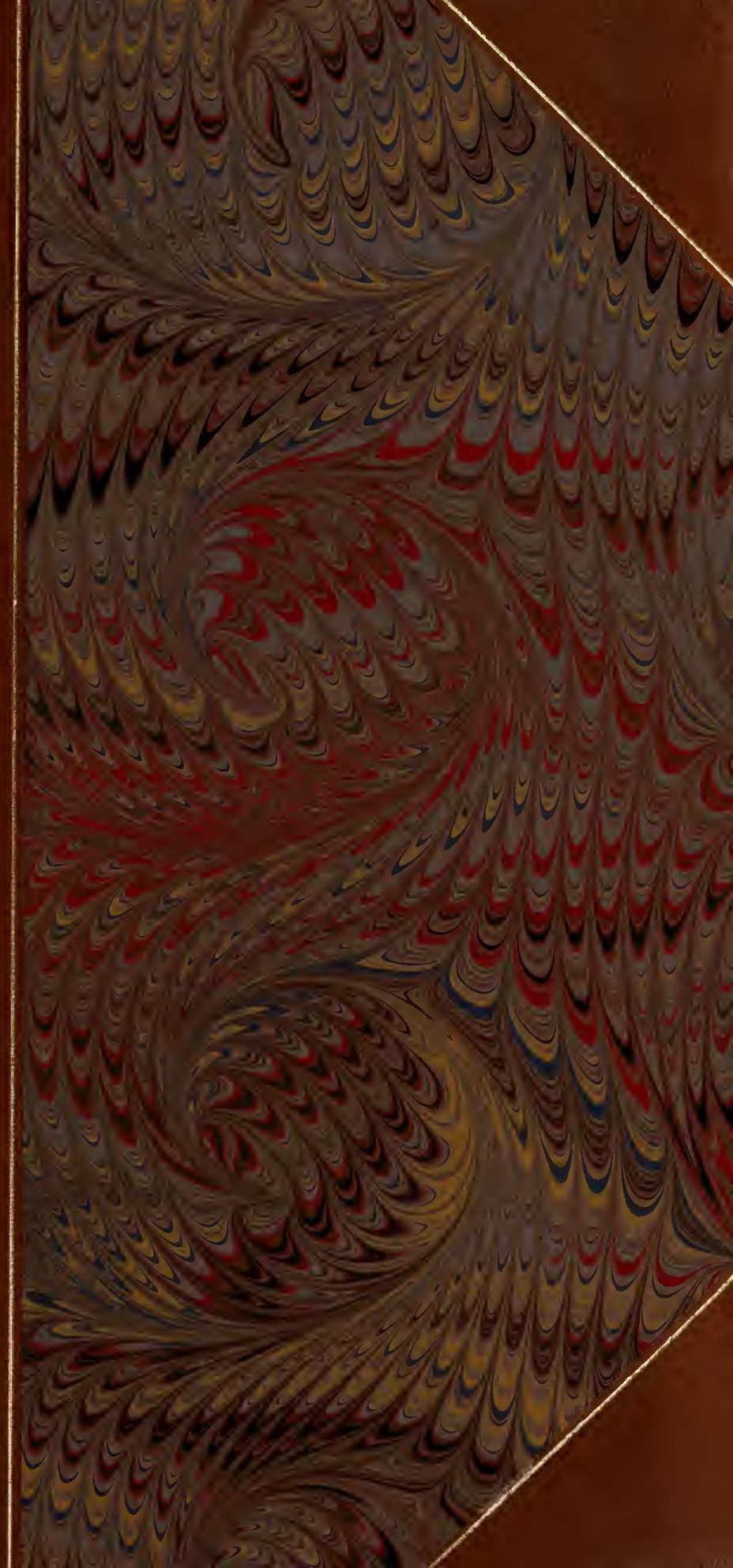




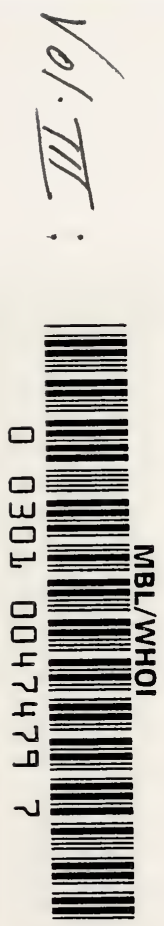
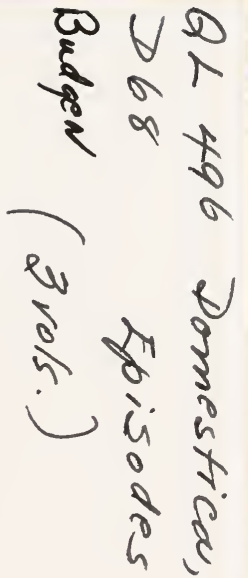

$x$

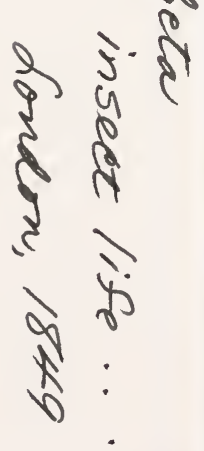









\section{EPISODES OF INSECT LIFE.}






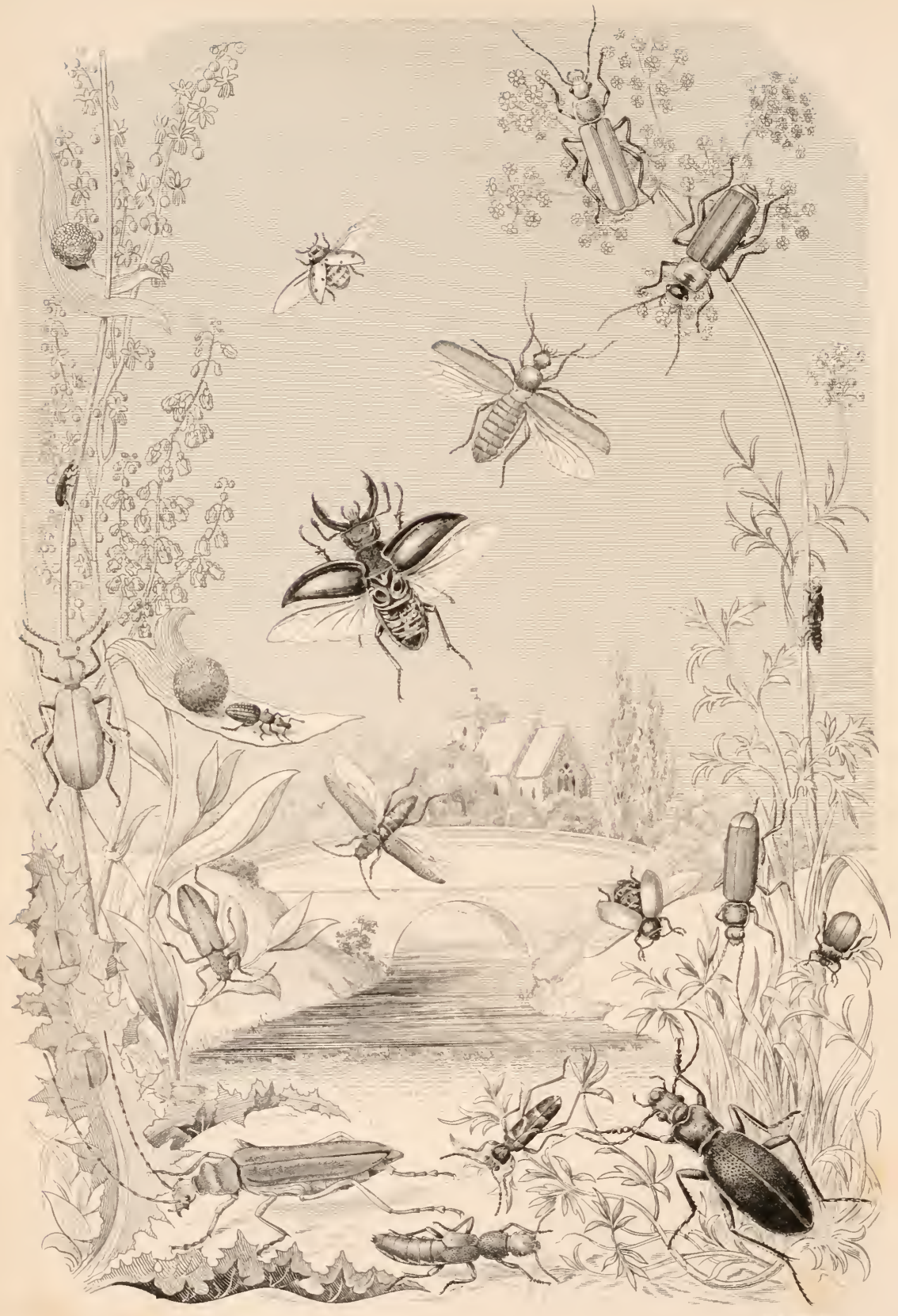


- Frederick Clarkson, NEW YORK.

\section{E P I S O D E S}

\section{OF \\ I N S E C T L I F E.}

BY ACHETA DOMESTICA, M.E.S.

Bu:

Third Series.

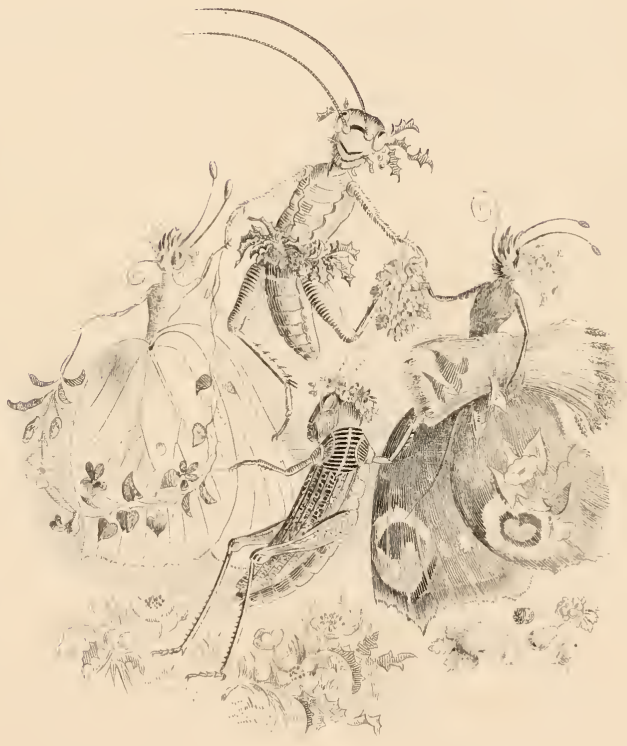

$$
\text { L O N DON : }
$$

REEVE AND BENHAM, HENRIETTA STREET, COVENT GARDEN 15.51 . 
ol $26-68$ 29:me t"

A2170 


\section{PREFACE。}

The accomplishment of an undertaking (provided, of course, its object be not reprehensible) is always a subject of satisfaction, and must be so especially in a book begun with hesitation and much diffidence of success, occupying considerable time in completion, and dependent on public favour for completion at all. Of this description has been the task (albeit a pleasant one) involved in the present volumes, which their author cannot send forth in a threefold form without again adverting, and with due sense of obligation, to the condition last named-the friendly favour so essential to their appearance as a whole; scarcely less so than the genial influence of season and sunshine to the appearance of a perfect insect developed through its triple stages.

In making the above comparison, it is far from being intimated, that the third and final portion of the work now 
finished is possessed, like the imago of a butterfly, of any superiority over its preceding parts. Thus much only can be said for it-that as an insect, of what sort soever, is sure to become an object of increased interest to those who have followed it through its progressive stages, so it is hoped that the ensuing series, making up the entire of an entomological year, may be read with increased relish by those who have followed it through its progressive periods:-this, because with all that pertains to natural knowledge "l'appétit vient en mangeant."

To the same class of subjects belongs yet another merit, noticeable here because most sensibly felt, both by those that write and those that read, when they come to the conclusion of a book devoted to any one of them. In a sustained work of fiction, or even in one on an historic theme sedulously explored and vivificd con amore, a writer may often entertain, in common with his readers, a feeling of regret at having done with the persons and scenes of his own creation, or such as have become familiar in their recalment from the depths of the past; but it is never thus with the objects drawn from the world of nature. With these neither writer nor reader are ever called upon to part. They may have done, the former 
with presenting, the latter with having them presented, under some certain form, but to both, when once endeared by awakened interest, they are ever present, and for ever assuming new aspects to engage thought and kindle affection-adoration. Completed works on natural subjects? There are no such things! The most scientific of them is but the commencement of " a story without an end ;"- - the least so (this among them) is but an invocation to begin and read it! 



\title{
CONTENTS
}

\author{
AND
}

\section{DESCRIPTION OF ILLUSTRATIONS.}

\section{Jrontispiere.}

\section{BEETLES IN GENERAL.}

In assemblage of Beetles, most of which are deseribed or mentioned in Episodes of the two former or present series. (See, especially, 2nd series, p. 81 , \&e.)

On the plant of Meadow Sorrel (Acetosa pratensis) to the left, are two small Brown Treevils (Curculionida), with their globular eocoons attaehed to the sagittate leaves. Aseending by the stalks of the same plant is the Cardinal Beetle (Pyrochroa coccinea); and immediately below, two of the pretty little green "Tortoises" (Cassida equestris), which are found commonly on the leaves of thistles. The elegant Musk Beetle (Ceramby. moschatus), a Rove Beetle (Staphylinus olens), and a beetle of the family Lepturide, form the trio on the left and middle of the foreground, of whieh the right-hand comer is oceupied by one of the common Ground Beetles (Curabide). Dinectly above, head downwards, is the beautiful green and red Malachins bispinosus, allied to the Blister Beetle, and, one on either side of it, a pair of Chrysomelide (Golden Apples). Above, on the stalk of the umbelliferous Earth-nut (Bunium) is a small black Staphylinus; and on the blossom above, two speeies or varieties of the predatory beetles with soft elytra, of the family Telepho- 
rida, of which another, on the wing, is ascending towards them. T'o the left, above, flies a Seven-spot Ladybird (Coccinella septem-punctata). About the centre of the picture is a Stag Beetle (Lucanus cervus) on the wing; and below, one on the leaves of the Water Scorpion-grass (Myosotis palustris), the other descending towards it, are two of the Brassy-green Donacie, such as are found frequently ou aquatic plants.

\section{september.}

\section{LOVERS OF PLEASURE.}

The insects in this Vignette are of the allied families Achetide, Gryllide, and Locustide. On the bank, beside its nest-hole, is a Field Cricket (Acheta campestris). On the elover-leaves opposite sits a female Grasshopper (Gryllus), with her sword-shaped ovipositor. Ascending the grass above is one of the small green Locustida, common in damp) meadows; and flying upwards in the centre is the Acrydium (or Locusta) subulatum, a species with very small elytra, figured in Curtis's ' 13ritish Entomology'.

"Thou dost dance and thou dost sing."

A pair of Gryllida, Anacreontic types and patterns of supreme happiness.

\section{PARASITES:}

On a Currant-leaf in the foregronnd lies a caterpillar of the Magpic Moth (Abraxas grossulariata), which has been picreed by a small Iehneumon (Microgaster glomeratus), black, with yellow legs, of which a magnified figure appears flying upwards on the left. Its parasitic larve, having fed upon the juices of the eaterpillar, have deserted its body, and spun around it their ovate silk cocoons. Above these, descending on the right, is the large common Ichneumon (Pimpla manifestator); and high in the corner opposite aseends another large speeies, black and orange, of the genus Ophion

" The Puss, in its grealness, a prey to parasites."

Wealth and grandeur, in likeness of a "Puss Caterpillar" (a prince amongst its fat fraternity), at once drained and incensed by parasitic satellites of the tribe Ichnetunon . . . . . . . . . . . . . 
37. JACK O' LANTERN IN ARMOUR.

A Mole Cricket (Gryllotalpa vulgaris) is the illustration of this Episode, which consists of a tale founded on the supposed luminosity of that insect

\section{"The phantom light suddenly fell."}

The mailed and handed and luminons insect, in the knightly semblance it assumed to the eye of "Tombstone Tim"

\section{INSTINCTS OF MATERNITY.}

In the foreground is an Earwig (Forficula vulgaris), surrounded by her brood as a hen by her chickens. Above, on the leaf of a rose-bush, is an outdoor Spider (a beantiful species, white with crimson markings), keeping guard over her numerous eggs, enveloped in a covering of bluish silk. The leaf behind her has been converted by her industry into a nest, from which, with her eggs, she is supposed to have been dislodged. On the wooden pale opposite is the excavated nest, with enclosed cocoons of a mother "Carpentress," amongst the solitary wasps (Eumenes), who is flying up towards it. On one of the leaflets of the rose above it, is a Leaf-cutter Bee (MLegachile centuncularis), employed in excision of one of the circular picces used in the lining of her nest; and above, flies auother of the same "Upholsterer" craft . . . . . . . . .80

"Admire the dexterity of the Leaf-cutter Bee."

A Maternal "Upholstress" shaping the material of her leaf-lined nest, which, in form of a cradle, is represented near her . . . . . . . .97

\section{FATHER LONGLEGS AND HIS FAMILY.}

On the grass, to the left, is one of the common brown Crane-flies (Tipula oleracea), distinguished as a female by her pointed ovipositor. In flight, above, is a male of the same species, and below, in the earth, another, in its state of grubhood, employed in devouring the grass roots, on which, in its earliest stage, it is accustomed to feed. On the right, above, is a handsome Crane-fly (Ctenophora), with black and yellow markings and plumed antennæ

"How vast (to an emmet) its stupendous elevation!"

A spacious platform and commanding observatory for crecping millions 


\section{Ortober.}

40. THE SCARABAUS AND ITS MODERN WORSHIPPERS.

Ascending the tombstone to the right, is the Churchyard Beetle (Blups mortisaga), listinguished by its intense blackness. Next, on the ground below, is a small, black, shining Dung Beetle (one of the Histerida); and adjacent, a pair of black and orange Necrophlori, notable for their industry in interment of animal remains. Climling the grass above, is the Silpha quadripunctata, a black and yellow feeder upon carrion; and in descending flight, lessened by distance, is that most common of beetle seavengers, the Dor, or Clock (Geotrupes stercorarius) . . 110

"The Scarabcus, an amasser of filth, fit emblem of mammonworship."

The Dung Beetle, set up on high for the adoration of the sordid

\section{INSECT DIRGE-PLAIERS.}

Eutering at the open easement, appear the head and shoulders of a Death'sheal Moth (Acherontic Atropos). The table below is oceupied by two Deathwatch Beetles (Anotium tessellutum and A. pertinax), while :mother (Anolium striatum) is creeping up the wall above. All three are drawn much larger than life . . . . . . . . . . . 12

"Phantoms foot it to the Deatluxatch drum."

A dance of death got up, at Superstition's bidding, to the beat of the dreaded Deathwateh

\section{SHORT LIVES AND LONG.}

'The insects chosen for this Vignette are such as afford examples either of longerity, of brevity of existence, or of great disproportions in the length of its several stages. The Brown Weevil (Curculio), a feeder on leeared rood, at the right hand corner, gires an instance of longevity, contrasted by the brief duration of the Ephemeral Day-fly (Bactes), which rises upwards on the left. In this Ephemera there are two insteal of (as in E. culgata) three filaments, proceeding from the extremity of the body. Ou the right, is a comnon Cockchafer (Melolontha vulgaris); another of the same species, just arrived at maturity, is pushing apwards from the grass; while a third, ret in its stage of larva, is 
exhibited in the ground beneath. In this, its form of imperfection, it cxists within the earth for several years, living in the air as a perfect insect for perhaps a fortnight. On the oak-leaf to the left are two leafgalls, one exhibiting its enclosed grub-a long liver, as compared with the little Gall-fly (Cynips Quercus folii), which is seen in upward flight above

"The threads of insect life are variously apportioned."

The Parce meting the lengths of insect existence, allowing them the shortest measure in their perfect and brightest stages . . . . . . . . .159

\section{STARS OF THE EARTH.}

On the right, creeping down the bank, is a common Glowworm, the wingless temale of a beetle (Lampyris noctiluca) which is seen descending from the corner opposite. Beneath, crawls a luminous or electric Centipede (Scolopendra electrica): and near, in the centre of the foreground, is one of our native (lick Beetles (E/aterida), not (as represented by mistake) a luminous insect, but closely allied to, and much resembling, the FireHy (Eluter noctilucus) of the West Indies and South Ameriea . . 160

"Liquire we the uses of the Glowworm's lamp?"

It here supplies to a studious fairy the purpose of the midnight oil

\section{\$2ubentber.}

\section{INSECT HOVEMENTS.}

The examples of slow and swift-footed beetles here given, are the Oil Beetle (Proscarabaus vulgaris), laborionsly creeping up, and the Tiger Beetlc (Cicindela campestris), rapidly descending the sandy bank. Below, is a fast walker, almost rumer, among hairy caterpillars, and above, on a lime-tree twig, sits the stately larva of the Lime Hawk Moth (Smerinthus Tilia), like the rest of its Sphinx-like brethren, slor -footed and averse to motion. The two flies are of a flower-resorting species, called vibrating (Scioptera vibrair), which are distinguished by red heads, scarlet eyes, black-tipped wings, and that quirering or vibrating motion to which they owe their name 


\section{"In the swift Tiger and slow Oil Beetles, see the fabled hare and tortoise."}

The rapid Cicindela, diverted from its course by the sight of insect prey, exemplifies anew the old adage, that " the race is not always to the swift" 201

\section{FOR THOSE IVHO ARE NOT OVER-NICE.}

All the insects of this group, excepting one, consist of Plant Bugs (Pentatomida, Capsida, \&c.) of varied form and colour. The dark, long-bodied insect creeping up the palings, is the Reduvius personatus, a bug itself, but an enemy, especially in its stage of larva, to our domestic horror Cimex lectularizs. The Plant Bug, on a branch of Sonthernwood below, is remarkable for a pair of singularly-shaped antenne, and its wings (not shown in the figure) are of a beautiful riolet-bluc: the general colour of the insect is a dark olive

"Steeds of mettle and muscle, for a steeple-chase in camest."

If chases such as these were never calendared in graver fashion-if, as here, the vaulters were but Fleas-the chase but "coming off" on paper, the horse might leap for joy, the man rise higher, that is, to bis proper place, as an animal of reason and humanity

\section{STORY OF AN OGRE.}

The insect Ogre here represented is the fieree and wily grub of the Ant-lion (Formica Leo). On the fragment in the foreground it is shown in dcformity uuveiled, and more backward is seen one of the cleverly-constructed pitfalls in which it is accustomed to lie buried, all but its extended jaws, for the entrapment of its prey. The globular object towards the left is the puparium, or pupa-case, of this remarkable creature, itself remarkable for the smallness of its size, as compared with that of the imago (winged insect), which is shown in process of emergement from it. It its perfect expansion, it soars above-the Ant-lion Fly complete

"Together with the ball they lift her on their shoulders."

The Formic heroine (a eaptive Aut) escapes from the clutches of the Ant-lion Ogre, by concealment in the hollow ball (pupurium) of the monster's own weaving . 
47. PAINTING, CARIING, AND GILDING.

The inseets assembled in this Vignette afford only average specimens of Nature's deeorative skill, but serve to illustrate the three modes above mentioned of insect adornment. In the Moth Caterpillar, with its goldfineh colours (scarlet, yellow, blaek, white, and brown), resting on a braneh of elm, we have an example of gay painting wanting permanenee. This latter quality is supplied in the Ruby-tailed Wasp (Chrysis ignita) on the paling. Above, are two larvæ (pseudo-caterpillars) of the Currant Saw-fly (Nematus Ribes), their skins of greenish-yellow, stndded witl raised dots of shining blaek. On the nettle-stalk adjacent lrangs the gilded ehrysalis of a Tortoiseshell Butterfly (Vanessa Urtica); and above, flying upwards, its superior wings laden with seeming gold, is one of the little Moths (Tineida) eome of eaterpillars which feed on the bark of Bireh-trees. Also inseribed in mimic gold is the Greek $\gamma$, whieh gives name to the larger Moth (Plusia gamma), seen on wing beneath the flower-head of Knapweed (Phrygia nigra), seated on whieh, her closed pinions "freaked" on their reverse, not with gold, but silver, is a brown Fritillary (Argynnis Adlippe). The ouly speeimen of insect Carving for which room has been here found, is one of the sculptured eggs of the $\gamma$ Moth on a leaf of Knapweed

"You shame our trumpery daubing!"

Acheta throws down his pencil in despair at the inimitable perfection of his living patterns

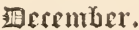

\section{SPIDERS IN TITEIR ANALOGIES WITH OTHER ORDERS OF CREATION.}

The two Spiders on the top of the wall are of the tribe called "Hunters," as opposed to "Sedentaries," or such as construet snares and sit within or beside them. That on the right, with zebra-like stripes, is the Salticus scenicus; opposite, is a nearly resembling speeies; and climbing the Wall-flower, is a beautifully-coloured geometric Web-Wearer . . 276

"Where are snare-setters existent but amongst human animals and Spiders?"

The Man Bird-eatcher emulated in his trade by the Spider Fly-cateher 
On the canal in front are several insects and objects of insect fabrication, such as might have been suggestive to man of the Art of Navigation. Nearest, on the right, rowing itself down the curreut, is a Boat-fly; on a line with it, to the left, the egg-boat of a common Gnat; and betwixt them, the raft of a raft-making Spider, bearing its constructor. Closer to the rail appears the diving-bell of the Diving Water-Spider. The case at the back is oceupied by rarious specimens of inseet skill, and a few of the tools employed in their construction. On the lowest shelf, to the right, is the nest of the Mason Bee, with its hole of entrance; cells, the work of a similar insect, appearing in the mortar of two detached pieces of wall placed behiud it. Next to these, in the compartment adjoining, is a fragment of sand-stone, in which are screral nests of Mason Wasps, with the leaning or curved towers raised over them in process of excavation. Beside these, is a picce of wood tumelled, for her nurseries, by a Violet Carpenter Bee, each divided into eells by partitions of cemented sawdust, and stored with heaps of pollen. The perforatious in the wood are openings to passages which communicate with the eclls. Next in order, is anuther specimen of the same; and nearer to the left is the nest of another bee Carpenter, also tunnclled in a piece of wood, but divided by partitions of clay, instead of sawdust. The first object to the right, on the shelf above, is the cell, as constructed in earth, of an Earth-Mason Caterpillar. It is open, to show the interior, which is smooth, and lined with silk for the comfort of the chrysalis which lies withiu. Next, on a piece of wood, and composed of detached fragments of the same material, is the cocoon or eell of at caterpillar of the Puss Moth. The next is that of a Goat Moth-the winter abode of its long-lived larva in the heart of a tree ; - a portion of the wood wherein it is imbedded, being cut away, shows its fabric, a cloth-like substance of mingled silk and raspings of wood. On the upper shelf of all are three tools, used by insect artificers. To the left are the powerful toothed jaws, constituting chiscl, plane, and forecps of a Mason Wasp. Next, in the centre, is the compound tool, consisting of an anger and a pair of files, used by the Tree-hopper, to make grooves in branches for recption of her eggs; and to the right, is a portion of the saw used by Saw-flics for a similar purpose . . . 296 
"We challenge all the nations."

Insect artizans, whose tools of divine adaptation, and works divinely guided, defy, unpresumingly, all human competition . . . . . . . 33:3

50. TWO THINGS OF DIFFICULT DEFINITION.

The subject of this Vignette is the Parsonage House at Barham, Suffolk, of the late venerable and lamented Mr. Kirby, the distinguished author, in conjunction with Mr. Spence, of the well-known 'Introduction to Entomology,' and of one of the 'Bridgewater Treatises.' The Wasp in the foreground, employed in cutting off the wings of a fly, with a view to its more convenient transport, is illustrative of an anecdote given by Dr. Darwin, and quoted by Kirby, in his observations on two classes of insect activities-those prompted solely by Instinct, and those guided by apparent Reason . . . . . . . . . . . . . . . . 33

"More ways than one of getting at the bottom of a secret."

A portly Humble Bee, one too bulky for entrance at the spring door of the Snapdragon, leading to its nectary, bores a hole at the bottom of the floral cask to obtain its honeyed wine . . . . . . . . . . 357

51. THE SPIRITS OF HEARTH AND HOME.

A trio of common Cockroaches (Blatta Germanica), commonly misnamed Black Beetles, are the invaders of the kitchen here represented . . 358 "Memory, painter of the past, let us invoke thee."

Acheta, in a review of past stages, traces the development of his own imago, his present self 



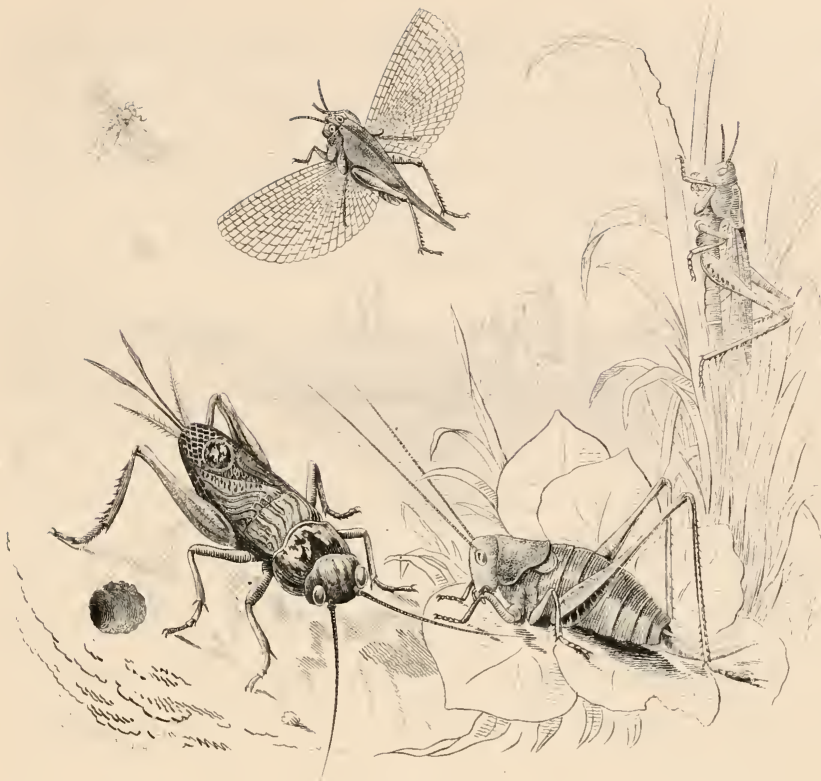

LOVERS OF PLEASURE.

"The joys of earth and air are thine entire, That with thy feet and wings dost hop and fly : Aud when thy poppy works, thou dost retire 'To thy carved acorn-bed to lie.

"But ah! the sickle!-golden ears are cropped,

Ceres and Bacchus bid good-night;

Sharp frosty fingers all your flowers have topped, And what scythes spared, winds chase off quite."

Differenc nations would seem to have as opposite ideas about happiness as about beauty. The Japanese, for instance, have selected that half-dead liver of centuries, the tortoise, to figure their idea of perfect enjoyment, while a 
Grecian poet chose the grasshopper, so eminently a creature of life, living through every hour of its single summer, as a representative of surpassing bliss, deserving the apostrophe of

"Happy insect! what can be

In happiness compared to thee?"

But know you not, says the entomologist, that these lines of Anacreon have been only by error and mistranslation assigned to the English grasshopper, at cost of the Grecian tree-hopper, to whom they properly belong? True; but if we examine, somewhat entomologically, the well-known ode commencing with the above couplet, we shall perhaps find that each of the attributes, real or figurative, which it assigns to the classic songster of the tree, suit as well, and some of them much better, our rustic songster of the grass.

We may notice in the first place, that the tree-hopper, called by the Greeks Tettix, by the Latins Cicada, received also from the former the title of "Earth-born,"-a title lofty in its lowliness, because it was an implied acknowledgment from men of $\Lambda$ thens and of Arcady of a common origin with themselves - an admission that the insect was their brother, sprung (as they fabled) from the earth, their common parent, -whence, also, they wore golden tree-hoppers in their hair. The Grecians would have learnt, however, by a little closer observation, that instead of springing full-formed from the ground, as their goddess Minerva full-armed from the parental head, the infant tree-hopper was accustomed to emerge 
from the egg within a protecting fissure in some lofty branch -a groove formed by its mother with instinctive foresight, aided by efficient tools wherewith the Great Parent of all had furnished her. "Earth-born," therefore, was a term by no means applicable to the tree-born Tettix; whereas, to our grasshopper, who first emerges into life within a nest excavated in the ground, it is not, in a limited sense, inappropriate.

To return now to our ode.*-

"Happy insect! what can be

In happiness compared to thee?"

This felicity, without pretending to decide on its comparative or positive amount, we may fairly suppose to be tolerably equal with the hoppers of the tree and of the grass.

"Fed with nourishment divine,

The dewy morning's gentle wine,

Nature waits upon thee still,

And thy verdant cup does fill;

'Tis filled wherever thou dost tread,

Nature's self thy Ganymede!"

This may be said no less truly than prettily of both our summer minstrels, only with reservation. Both, doubtless, take a similar delight in quaffing the "morning's gentle wine," the one, from the emerald salver of a leaf, the other, from the golden chalice of a buttercup; but, as vegetable feeders, both of no mean appetite, this " nourishment divine" 
would, by itself, serve them only poorly; witness for our grasshopper,
" the juiey leaf to which he elings, And gnaws it like a file;

The naked stalks which wither by

Where he has been erewhile."

And as for the trec-hopper, one of the uses of the gimletlike tool with which it is provided is said to be that of tapping trees, after the manner of housewives' tapping birches for their sappy wine. $-\Lambda$ propos of feeding: a certain species of tree-hopper has been observed to display a curious kind of instinctive sagacity. These insects, which resort to the ash-trees of Sicily, are said to bore holes in the bark, and, when the manna has oozed out, to return and carry it away. Hence their name of "Mannifer"a" in the Limnæan system.

\section{"Thou dost dance, and thon dost sing, Happier than the happiest king!"}

The first line may serve, in a measure, both for Grecian Tettix and for English grasshopper. If, however, the comparative merits of their dancing be adjudged according to the wonder rather than the grace of their performances, the "pas," we fancy, must be given for once to the British artiste, who, showing a leg of proportions far more muscular than that of the foreigner, can execute a surprising vault of his own length two hundred times repeated. On the other hand, as regards song, the singer, or, as some modern 
critics* have disrespectfully called him, the squaller, both of ancient Greece and modern Italy, must be allowed, if power and shrillness be the criterions of excellence, to carry it hollow over our native serenader.

Be it noticed, however, by the way, that neither foreigner nor native are vocal, but, in reality-instrumental performers. Thus considered, the grasshopper is as a shepherd with his Pandean reeds, or pipe and tabor, and the treehopper, by all accounts, as a deafening bagpiper-his shrilly clamour audible, it is said, at a mile's distance.

As for being "happier than the happiest king," the poet might have chosen, we imagine, a happier expression to express the supreme felicity of his monarch of the trees,-supposing, that is, the amount of happiness comprised within the golden circlet of a crown to be no bigger than philosophers, and poets also, have usually considered it.

Royalty is not, however, what it was; and now that, in company with Belle-Dame butterflies, $\uparrow$ a king or queen can flutter in the mountain breezes, or take flights of pleasure across the seas, they need not (at least for lack of liberty) envy the verdant reign of a roving grasshopper. And yet we know not; for as majesty casts off its gilded fetters of state, the impertinent " million" would cast off, in proportion, its

* Dr. Shaw, \&c.

$\uparrow$ Belle Dame, Painted Lady Butterfly (Cynthia Cardui). A butterfly of range most widely extended; frequently also crossing seas. 
own fetters of subjection; and now, in these autumn days of royalty, when diadems have fallen, and some, like autumn leaves, are trembling, we must perhaps say still, as was said even while monarchy was in her summer prime,

\section{"Uneasy lies the head that wears a crown!"}

To return now to our insect monarchs of the tree and of the grass.-

"All the fields which thou dost see,

, All the plants belong to thee!

All that summer hours prodice,

Fertile made with early juice ;

Man for thee doth sow and plongh,

Farmer he, and landlord thou!"

In the undisputed range of their several territories, whether of foliage or of grass, our two appropriators may be reckoned much upon a par; though he of the tree can certainly, from his loftier position, boast of a wider and more absolute command. For this reason (considering both as kings) King Treehopper may be also, if not the happier, the safer of the two.

As for the labours of man being made subservient to the insect's use, this certainly is a distinction which belongs much more properly to the grasshopper, the "landlord," if you will, of our meadows and our corn-fields, until at midsummer, or in harvest (his position reversed) he finds himself a tenant, forcibly ejected at the point of scythe or sickle.

"Thou dost innocently joy,

Nor does thy luxury destroy." 
Here let us stop and compare, as applied to both our revellers of the summer, the dictum of poet and the evidence of naturalist.

First for judgment on the tree-hopper. The insect of Anacreon might and may possibly be of more innoxious character; but we are told by Stoll, that the common species of Tettix or Cicalla, what he calls "La Cigale Vieilleuse," does infinite injury to trees, especially to plantations of coffee, * by boring grooves and holes in the smaller branches, both for the deposition of eggs and for extracting juices.

Now, Mr. Grasshopper! Are thy "joy" and "luxury" the joy and luxury of perfect innocence? On ocular evidence dost thou stand condemned. Each notch in the verdant, much more the withering blade, is as a mouth opened against thee in mute accusation. True, we hear and read but little of thy misdemeanors, while those of "the fly," + and " the wireworm," $\ddagger$ and "the grub," $\$$ are trumpeted loudly forth, and figure infamously in the 'Newgate Calendar' of the indignant farmer. Yet do we suspect, that where thou and thy merry companions most abound, even in the meads of England, the mouthfulls of the cow must lack moisture, and the crops of hay lack weight; and when we read of thy continental fellows caught in hand-nets by the bushel, what must we think of the amount of mischief committed, or likely to have been wrought, by the combination of their jaws! But, however

* At Surinam.

+ Aphides of the hop, so called.

$\ddagger$ Larva of the Click Beetle.

§ Larra of the Cuckehafer. 
deep the damage they effected, direful was the penalty they had to pay; - when boiled, and their green coats reddened, like those of lobsters or of shrimps, they were served up, a friand repas, a dainty dish, to porkers. Returning again to our theme:

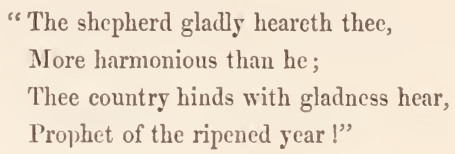

The Grecian lyrist, and the Grecian shepherd, and the Grecian hind, were all accustomed, doubtless, to welcome with becoming joyfulness the earliest strains of their summer treehopper, which, however intrinsically harsh, would seem, in their ears, full fraught with melody, as singing of verdure present, and of golden stores to come, wherein they were each to have his portion. So with our grasshopper; - - his petty larcenies overlooked or forgiven, his merry chirpings might sound, perhaps, no less cheery of promise in the ear of English peasant, were it not, alack! that they can meet so seldom with cheerful echoes in his heart.

We know not how it was with the Damons and the Phillises of our golden age (if they, or it, ever existed save in fable); but in these, our iron times, what shepherd or what hind (of poets we say nothing) can have an ear for chirp of merry grasshopper, or song of joyous bird, or bleat of playful lambkin, when the cry of starring children follows him each morning from his sorry threshold, and each evening meets him 
on return? and what to him, if repeated in summer's blithest accents, the "prophecy" of a "ripened year," when in its harvests, save their labour, he knows he is to bear no part of fair proportion?

The poet to the tree-hopper thus concludes:-

"To thee, of all things upon earth,

Life is no longer than thy mirth;

Happy insect! happy, thou

Dost neither age nor winter know ;

But when thou 'st drunk and danced and sung

Thy fill, the summer leaves among,

Sated with thy summer feast,

Thou retir'st to endless rest."

This will do alike for the tree- and the grasshopper, since, with both, a short life and a merry one is the allotted condition of being, extended only, we believe, to a few weeks of summer or early autumn. Neither they, their leaves, nor grass, nor "flowers," are much exposed, therefore, to those "frosty fingers" deprecated for the gryllus by the Cavalier Lovelace (writer of our prefatory lines), who, with true cavalier philosophy (only a variation on the Greek Epicurean), thus concludes his address to the English grasshopper :-

"Poor verdant fool! and now green ice; thy joys,

Large and as lasting as thy perch of grass,

Bid us lay in 'gainst winter rain, and poise

Their floods with an o'erflowing glass."

Auacreon's hopper of the tree and our British hopper of the grass may now surely be allowed to share between them the former's celebrated ode, and the palm of happiness and song. 
Our sketch comparative may possibly have excited in some of our readers a desire to compare for themselves the persons and the merits of our insect professors of the "joyeuse science;" but this, with the tree-hopper, is no easy matter. The Tettix of ancient Greece, and Cicada of ancient and modern Italy, has a place indeed amongst British insects, but it has been rarely seen in England, and only, we believe, in the New Forest, whose shades, however, would not seem to have resounded with its song. Allied insects there nevertheless are, of English birtl,-_some of them pretty, some of form remarkable, but none very likely to attract attention, for lack of size and song. There is, however, one species to be seen universally on hedges and in gardens all through the summer, which, in shape and make, will help to give a notion of the true Cicada. Though the person of this diminutive treelopper, at least before it attains maturity, is screened in a siugular manner from common observation, there is scarcely an iusect of more easy discovery when once we have penetrated the mystery of its white veil. Who has not noticed, about the time of the cuckoo's welcome advent, the leaves of hawthorn, hazel, woodbine - the leaves, in short, of almost every common shrub and plant in hedge and garden-begiuning to be besprinkled with frothy masses, which they know, probably, by the familiar appellation of 'cuckoo-spit'? Piuning on this nume their faith as to its nature, few people, perhaps, have crer taken the trouble to ascertain, as to the latter, the 
accuracy of their notions. Let such do so now by examination for themselves, and they will find, imbedded in the centre of each frothy "flocon," a little green, black-eyed insect,* from whose body the froth is none other than a secretion, intended, it would seem, to cover and protect its wingless infancy. If removed by violence, this frothy veil is gradually renewed; but as its little wearer approaches maturity it becomes curtailed and thinner. Then is our time, if we wish to acquire from this Tom Thumb of tree-hoppers some slender notion of his comparatively gigantic relative, the Grecian Singer, to pluck him, with leaf and branch, from his native tree, and set him up under a glass for inspection or exhibition. The veil of froth having shrunk to a film, we shall then discern, as each part of the insect emerges from a previous skin, first, a large, flat, frog-shaped head, with eyes set wide apart; then a triangular neck- or shouldcr-piece, flanked by small protuberances, which might seem apologies for wings; and, lastly, a short annulated body, pointed at the extremity. Six legs, of which the hinder pair, more strong and lengthy than their fellows, bespeak endowments of a leaping character, will complete, to all appearance, the somewhat grotesque figure of our little tree-hopper, or frog-hopper, as he is more generally called. But, though thus unveiled and thus uncased (his skin, perfect even to the legs, left behind him in silvery emptiness, like a shadow of his former self), we shall yet have to wait a little longer

* Tettigonia, or Cicada spumaria, C'uckoo-spit Frog-hopper. 
before we can behold him altogether a thing complete. He lacks not wings, only his wings want expansion; but, after about ten minutes, occupied in their unfolding from out the little shoulder-knots which yet encase them, will appear, in readiness for flight, two large transparent pinions, defended outwardly by a pair of less delicate texture. When the latter have put on their colours, most often variegated brown and white, behold a final and ample finish to the exterior of our frog-hopper, who, as soon as released from crystal durance, will afford, in an agile spring, half-flight, half-leap, an ocular demonstration of the fitness of his name.*

The first change of this little leaper (that, namely, from larva to pupa) was effected under cover of its frothy veil ; but this transition was only a moult, and not involving, as when a caterpillar becomes a chrysalis, a change of outward formthe pupa of the frog-hopper, retaining the legs, retains also the activity of the larva; nor in the third and final development is there, as we have just seen, much alteration of external shape, except the expansion of wings, before concealed. Such is the nature of insect transformation (so called) throughout the order Hemiptera, to which both tree- and frog-hopper belong; and such it is, also, in the order Orthoptera, of which the grasshopper, the cricket, and the locust are all distinguished, but sometimes confounded, members.

One mark of distinction in the family of Gryllida, or true * See Vignetle to 'Inscet Minstrelsy,' vol. ii. 
grasshoppers, as separate from that of locusts, consists in the length of their antennæ, which are always as long, often longer than the body, while those of the Locustide are generally shorter by one-half. In grasshoppers, and not in locusts, is also seen, sometimes, a sharp, sword-shaped instrument, projecting upwards from the linder part of the body. This appendage, peculiar to the female insect, is her tool for opening the earth and depositing her eggs within it; hence the French appellation of "sauterelles à sabre."

One of the largest and most conspicuous, both for size and song, of our native grasshoppers, is the "Large Green ;"* with rather a sharp head, large prominent eyes, ample wings, and slender antennæ as long as the body. This noble of his tribe is not an unfrequent resorter to hedges and marshy places; and, though his green armour may easily escape observation, his loud chirping can hardly fail to attract notice, especially amidst the general silence of the feathered choir, in the songless months of August and September. Favoured, however, by this pervading stillness, together with the long antennal ears wherewith nature has furnished him, he catches, presently, the sound of an approaching footfall, and ceases the music which might betray the secret of his lurking-place.

The above grandee of grasshoppers, as well as his more insignificant brethren, is in the frequent habit of filling up idle pauses between his music and his meals by a sort of

* Acrida viridissime. Vignette to 'Insect Minstrelsy.' 
seeming rumination, which many have considered an actual chewing of the cud; whereas it is opined by others, that, instead of ruminating, like Mistress Colly, the Sieur Gryllus thinks of nothing but of licking, like Miss Grimalkin, his superb whiskers (otherwise antennæ) and his paws, -an operation performed, by the way, with a tongue not at all dissimilar in shape to the unruly member boasted by ourselves. Whether or not chewers of the cud, grasshoppers are, decidedly, croppers of the grass; but we are assured, on good authority, that they now and then are nothing scrupulous in the variation of such Brahminian fare, by taking, as a relish, some innocent little inscet of a kind differing from themselves; still worse, that when made fellow-prisoners (hard pressed by hunger or confinement) they have been known to commit the cannibal enormity of devouring one another - an example being given wherein one of the gentler sex (which, by the way, among insects is usually the fiercer) was the doer of the deed. But, worst of all!-horror of horrors!- we have it on excellent evidence, how that a certain great green grasshopper (one of the sort just described) on being bottled up together with his orn leg (accidentally detached), did make a hearty meal off that late portion of himself. The reverend naturalist by whom this unnatural act is recorded, performed, himself, what in some prejudiced opinions might appear a crowning feat of horror. He followed the example of the Acridoplagi, and pronounced, on experience, the large green 
grasshopper of England to be "an excellent condiment." One species of gryllus, called the "Carnivorous,"* is indeed (as the name imports) even more of an animal than a vegetable feeder, as divers other insects, especially caterpillars, have discovered to their cost.

This, as well as the green, is a large handsome sort; but few people, to look at the insignificant size and sober colouring of most of our British grasshoppers, would expect to find amongst foreigners of their tribe, Asiatic, African, and American, some of the most splendid and curious of insects, rivalling even the Lepidoptera in the size and colouring of their wings-of which some are ocellated, or eyed, others leaf-like, others combining under one the singularity of the leaf insect with the bright hues of an eyed butterfly.

The Cricket, like the grasshopper, has long slender antennæ, but is distinguished from the latter by a thick roundish head, instead of one more or less pointed.

The most generally known of the Achetida, or Cricket family, in England, are those called the "Domestic," the "Field," and the "Mole." The singular form and habits of the last will be noticed in another place; and we have long ago described briefly the most salient points in the character of the fire-side chirper. His country cousin of the field is, like himself, known much more generally by sound than sight; $\dagger$ for, being of a shy, unsocial temper, it is not often

* Acrida verrucivora. $\dagger$ See Vignette. 
that we can get a peep (except by stratagem) at his black, gold-striped, shining jacket, or at the more duskily-coloured and more portly person of his female partner, who wears the pacifie sword of a "sauterelle c̀ sabre." No sooner are these timid little animals warned by their long antennal ears, directed to all quarters like those of a hare, that footsteps are approaching, than, forthwith ceasing their ehirp, they pop down into their holes among the grass, at the mouths of which they usually take up their stations.

After having essayed in vain to dislodge them by the spade from their subterranean eitadels, it was found by Mr. White that the insertion of a straw or pliant bit of grass would probe the windings of their eaverns, and bring to upper air the poor disquieted inhabitants. In a somewhat similar manner French children are said to fish for field crickets with long lines of horsehair, baited with an ant.

Early in March, the field cricket, with wings as yet eovered in their cases, and so enveloped till the month of April, opens his cell's mouth, and, sitting at its entrance, sings, or, to speak more correctly, plays through the summer days and nights, on to August, when all trace of him, audible and visible, disappears, with the obliteration even of the entrance to his late abode. The field ericket, like the grasshopper, is accustomed to fill up pauses in his music, by licking, erer and anon, his feet and whiskers with his rounded tongue, which, together with his jaws, is of course employed also, at other 
intervals, upon something of more edible description, in the way of breakfast, dinner, or supper. With most naturalists he has the reputation of being altogether a carnivorous animal -a snapper-up of unwary flies, and a feeder upon luscious caterpillars; others consider his staple food, as well as that of his domestic relative, to be entirely of a vegetable description; but the fact would seem that, as with our own convenient appetites, the families both of grasshopper and cricket can accommodate their taste to circumstances.

The family of Locusticle (locusts), though, as before noticed, often confounded with that of Gryllida (grasshoppers), are distinguishable from them by the inferior length of their antennæ, which are generally shorter by half than the body; also, by the absence in the female insect of the sword-shaped instrument employed, where given, to inter eggs within the ground.*

That prince of insect destroyers, the Migratory Locust, has appeared occasionally in Britain, also in the environs of Paris, as well as in southern Europe; but it is in Asia and Africa, chiefly in Barbary and Egypt, that the locust armies are known as mightiest of insect scourges. To give here any copied account of their destructive operations comes not within our province, any more than (happily!) within theirs our fertile isle of Britain. As regards the desolating mischief, and the ordered mode of their warfare in the East, none need want 
for information, when (to say nothing of the journals of modern travellers) they may turn in their Bibles to a more graphic description of the locust march than ever pen of traveller put to paper.

England produces various Locustide, insignificant in amount of destructiveness and size-inconspicuous, also, with regard to colour; but there are certain foreign insects of the same tribe whereon nature has been most profuse of ornament; their wings, as in some of the exotic grasshoppers before mentioned, displaying the most splendid combinations of colour, not enamelled, as in some brilliant beetles, nor laid in mosaic, as in the butterfly, but dyed, as it were, through the transparent or semi-transparent substances of the wings or wingcases, which, in this tribc, are technically called tegmina.

For beautiful figures of these superb insects, we may refer our readers to the elegantly illustrated works of Stoll and of Madame Merian.

We must say good-bye for the present to our grasshopper and the "Epicurean" fellows of his order, but not without a concluding word or tro on their singular fitness to represent the low sensual enjoyments of us, their " earth-born" and earthy fellow-beings. If not the happiest, they are all certainly among the idlest of insects,-eminently players, as distinguished from those which mingle work and play together; and if we adhere still to the naturalist's division of their tribe into its three distinct families of grasshopper, cricket, and 
locust, we shall perceive the closeness of their analogy to three several classes of worldly pleasure-seekers.

First, there is the grasshopper, which we look upon as a playful, harmless creature;-and so, by comparison, he is. His appetite is not vitiate and depraved, like that of his housebred cousin, Cricket, nor inordinately rapacious, like that of the wide destroyer, Locust. He and his enjoyments are simply rustic, and, as such, comparatively pure; but still he is a mere creature of idle pleasure. His life is neither a pattern nor a type of anything beyond low animal enjoyment. He labours to no prospective end, like the ant and the bee; although possessed of wings, he rises to no aerial flights, like the beetle and the butterfly. His active porwers are exerted chiefly to satisfy his appetite or escape immediate danger, and, unlike those winged insects which were once but worms, he ends existence in a form but slightly altered from that in which it was begun.

These dwellers in the grass are no unfitting representatives of a multitude of dwellers in the country.

Of what description may these be?

It needs not to specify their usual callings or positions in society. We shall simply ask if there are not, among country residents, a large proportion of harmless, sociable, good sort of people, who are, nevertheless, mere lovers of pleasure, inasmuch as they live only for the gratification of the moment;-persons who, dwelling in the midst of all that is fresh, and green, and VOL. III. 
beautiful, take, with the grasshopper, their animal delight therein, but, never converting the delights of nature into matter of mental store and profit, resemble not the bee, who doubles, by an internal process, the value of her floral sweets ; people who disport themselves amidst the fields, and live upon their products, but whose thoughts, never raised to the Divine Source of the beautiful and the good, admit of no parallel with the flights of the butterfly towards the source of day, resembling rather the leaps from one blade to another of the heedless grasshopper, who never cares to rise upon his ample wings into the bright blue sky above him.

Come we next to the Cricket - the fire-basking, thirsty, greedy, always feeding, never-fattened "Acheta domestica," or House Cricket.

But, stay! what are we about? Are we not committing moral suicide? stabbing our own reputation through the lanky sides of the little animal we have chosen for our repre. sentative? Nay, not so, altogether. There are two sides of a parallel, as well as two sides of a medal; and, if you will turn, Reader, to our opening paper, you will find that we have placed ourselves, as might have been expected, on the brightest.

We may observe, also, that our insect emblem is described as (although a domestic) a country cricket,-a partaker, as such, of country pleasures-a resorter to sunny banks in summer, as well as glowing hearths in winter; whereas a cricket, townborn, town-bred, and an exclusive dweller in brick and mortar, 
must be here understood to symbolize those lovers of pleasure, deeper dyed than the last referred to, who are immersed in metropolitan delights.

Of the town-bred cricket, artificial heat and glare make up the favourite atmosphere. Night is his day-noise his expression of enjoyment. For ever seeking, and, when found, for ever feasting upon, aliment of the grossest kind, and apparently foreign to his nature, yet is he (as a quaint old writer marvels) "wondrous lank and void of superfluity." No less thirsty than voracious, he is always drinking, yet always dry, until his thirst be quenched (as often happens) by the death which overtakes him in the water-pot or milk-pan.

Is not such a creature a fit image of the votaries of town dissipation? of those who convert night into day-who are for ever craving after unwholesome and unsatisfying pleasures, for ever thirsting after glittering delusive streams, which either, as with Tantalus, forsake his lips, or drown him in their souldestroying depths?

Thirdly, and finally, we have a class of pleasure-seekers, compared with which the two last-mentioned are harmless and innocent, in about the same proportion as the grasshopper and the cricket, when compared with the all-destroying locustand of these the locust only is the proper emblem.

Let us follow rapidly a locust march of destruction; let us see their troops in terrible array (though as yet in their wingless youth), pressing forwards — forwards - "running like 
mighty men-climbing the wall like men of war-marching every one on his ways, and not breaking their ranks"*entering houses-filling up streams and water-trenches, the dead bodies of their vanguard serving as bridges for the rear of their army to pass over-and putting out fires lighted in vain to oppose their progress. A temporary halt ensues; then, in a more perfect form-still of destructiveness-the now winged legions rise, darkening the sun, and again forwardsforwards with the wind-rapidly pursue their course, "the land as the garden of Eden before them, and behind them a desolate wilderness." $\dagger$ On, on they go, sceming to follow only the instinct of their own voracious appetites or the force of the driving wind; but an unseen power-the power that guides alike the sweeping whirlwind and the puny insect-is conducting their course, and leading them to self-destruction. Impelled scawards, they fall, and perish in the waters.

With only a trifling change of terms, the above description of the locusts' march would scrve nearly as well to depict the destructive progress of those lovers of pleasure who stand in direct opposition to such as are lovers of God. In their terrible progress, singly or in congregated troops of iniquity, what obstacle can oppose their headlong course? To attain the object of their selfish appetites, what social barrier will they not climb over? what domestic privacy will they not invade? what pure stream of felicity will they not pollute?

$$
\text { * Joel, ii. } 7 \text { - } \quad+\text { Joel, ii. } 3 .
$$


what household fires will they not extinguish, leaving desolate hearths and homes behind?

But that Power, who by the bridle of instinct conducts the migratory locust to perish in the wares, has set bounds also to the career of the locust of society. He is not impelled irresistibly, like his insect prototype, to his own destruction; but if he turn not from his course he is borne by the current of rice into the gulf of perdition.

The analogy between locust legions and lovers of guilty pleasure holds good even after deatl. Cast up by the sea, and left upon the shore-a bank of corruption-the insect remains infect the air, and complete by pestilence their previous work of destruction. And so, when swept by death from the face of society, the moral locust fails not to leave behind the ill odour and pestilential influence of corrupt example.

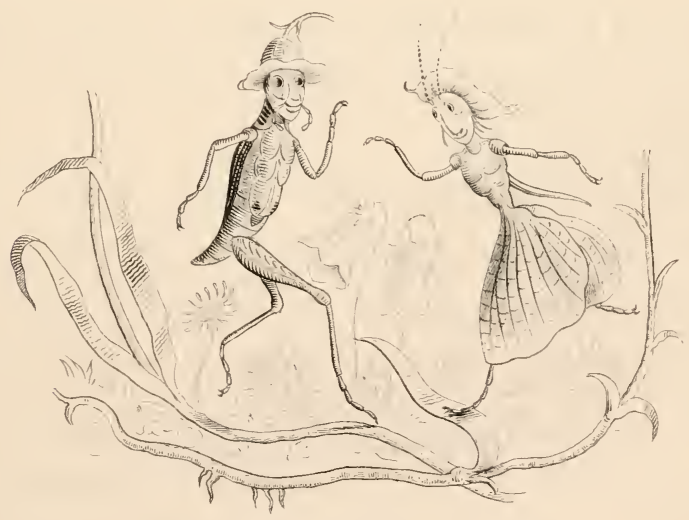

Thou dosf dunce and thau dost sitng!" 


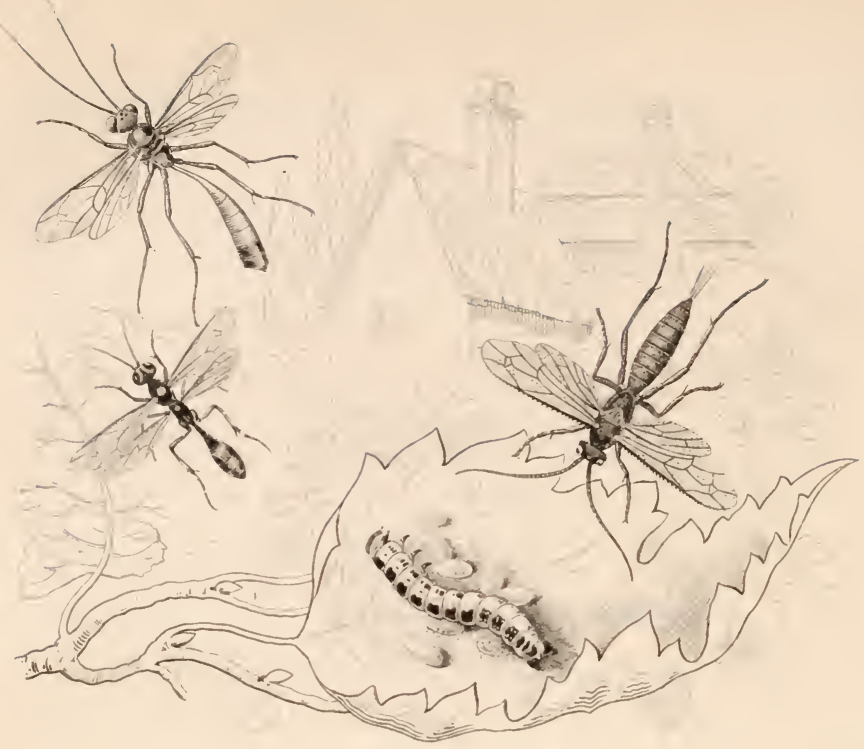

\section{PARASITES.}

The better fed, the longer kept."

There is a certain destructive tribe of insects which may be seen everywhere; and they may be seen not only now, but at almost every season.

The varied species of insects which compose this tribe differ widely both in magnitude and in strength; but they are, one and all, according to their power, active, prying, and destructive. They are specious in outward form, but they are for ever watching opportunities to make breaches in the citadel of life, that they may introduce therein, sometimes a single assassin, sometimes a murderous host, 
which sap its foundations, and bring it, sooner or later, to destruction. The above description (that of parasitic insects) applies almost as exactly to those destructive spirits whose name is Legion, which are for ever seeking the life of the soul; generally, in the first instance (as with their insect prototypes) assailing it singly, but, wherever successful, making way for a multitude of vices, sprung from the original, to complete the work their parent has begun. Our business is not with parasitic vices (except our own), but with parasitic flies. The analogy, however, betwixt the two affords so striking a text of one homily of nature, that, though pointed out before,* we note it here, as a comparison to be kept in view, extended, and applied, while we trace the proceedings of a notable few amongst the most insidious of all insect destroyers of insect vitality.

Icluneumon is the name generally applied to the parasitic race of which we have been speaking. There are, however, various insects of parasitic habits which are not properly ichneumous, though the name, as signifying pryers, does not ill befit them.

The original ichneumon of antiquity was, as most people are aware, no insect at all, but a little four-footed animal, a pryer after, and devourer of, crocodiles' eggs, on which account it was adored by the deifying people of Egypt as among their benefactors; and amongst ours we are bound, certainly, to rank its insect namesakes, prying, as they do, 
for our benefit, after caterpillars in the egg as well as in maturity.

But the extensive value of ichneumons, as a check upon caterpillar depredation, may be best estimated by their numbers, of which we may form a tolerable notion when we hear of above 1,300 species* in Europe only, some so minute "that the egg of a butterfly is sufficient for the support of two [individuals] until they reach maturity; others so large that the body of a full-grown caterpillar does not more than suffice for one." $†$

Aristotle is said to have first applied the name of Ichneumon to the wasp; and certain wasps there are, betwixt whom and ichneumon-flies, properly so called, there is not a pin to choose, as regards their prying parasitic habits. The ichneumons belong also to the same order (that of Hymenopter $a$ ) as wasps and bees; both, spite of their relationship, among the objects of their treacherous attack.

Of this distant kinship there are outward traces in the four transparent wings, and in the slight wasp-like attachment of the ichneumon's breast and abdomen, also in its prevailing colours of black and orange; but the ichneumon, whether a dwarf or a giant of its family, has a figure of such peculiar cut as to make it easy enough, when acquainted with one, to recognize a hundred of his name. We may know them by their long narrow bodies, so convenient for prying and poking into holes and corners, as well as by their long, flexible, jointed horns,

* 'Naturalist's Library.'

† Kirby and Spence, Introduction. 
so continually on the vibrate as to have procured for their possessors the appellation of Musca vibrantes. With these organs* (supposed to combine the uses of feelers and of ears) our pryers are to be seen for ever exploring, both by touch and hearing, the places and the living subjects best suited to receive their eggs.

Cuckoo-flies is another appellation by which ichneumons are distinguished, because, like the cuckoo, they are accustomed, lazily, intrusively, dishonestly, and cruelly, to deposit their eggs in stranger nests-sometimes within stranger eggshells-sometimes within the bodies of stranger grubs and caterpillars, either in their infancy or when they have attained their growth. For execution of these her nefarious practices, the female ichneumon is provided with a very conspicuous instrument, tail-like, seeming composed sometimes of one, sometimes of three divergent hairs, but consisting, in fact, of a single ovipositor, or borer, with a sheath longitudinally divided and opening like a pair of compasses. The nicest adaptation marks this curious instrument, which, according to the different species and habits of its possessor, is employed to pierce, sometimes only an exposed egg, sometimes the skin of a grub, caterpillar, or chrysalis, and sometimes through defences strong and deep, coverings of silk, or wood, or clay; and, according to these varied requisitions, it is shorter or longer, thinner or thicker, stiffer or more pliant. In one large 
and common ichneumon, ${ }^{*}$ easily known by her black body, red legs, and smoke-coloured wings, spotted at the base, this taillike appendage reaches unto inches, sometimes nearly three - a length, extreme, as longer than the body, but not superfluous, seeing that its office is often to penetrate, and that through a barrier of clay, down to the very bottom of deep nest-holes in walls or sand-banks, those, usually, of the mason wasp, wherein, to the destruction of the hapless nestling, its rightful occupant, it leares behind the fatal deposit of a parasitic egg.

If the maternal mason has, according to custom, provisioned her nest, she has only, in providing for her offspring, furnished a ready store for its cuckoo-like destroyer. In thus invading the nurscry-fortress of a marauding, life-destroying wasp, we may view the proceedings of this long-tailed ichneumon, however cruel, with some indulgence on account of their retributive character. Not so, however, with the doings (to all appearance, barbarous in the extreme) of various other species towards the quiet, peaceful caterpillar,-insect-warl, a most innocent member of socicty. We know, however, only too well, that in its relation to ourselves the caterpillar holds a somewhat different position, and, having acknowledged already the services of Mother Ichneumon in reduction of the caterpillar crew, we must not quarrel, we suppose, with her mode of effecting this desirable end. Let us see now-though no 
very pleasant thing to look upon or think of-the way in which she often goes to work upon a poor devoted devourer of the leaves of cabbage, one of the commonest of all caterpillars, whence spring one of the commonest of all butterflies-the Large White* of the garden.

While stuffing its variegated doublet of green, black, and yellow, with vegetable pulp, a small ichneumon, a little fourwinged imp, with black body and yellow legs, pounces on its back, flourishes her tremendous egg-inserting weapon, and, seeking therewith the caterpillar's most vulnerable part, plunges it, now here, now there, between its rings, leaving, with every puncture, a "thorn in the flesh," soon to be the living prey of a brood of devourers.

The victim of this infliction bears all with a most astonishing degree of quietude; and, without any outward signs of the visitation which has befallen it, continues to discuss its cabbage with apparently the same relish as before, and utterly unconscious that, while seeming to feed only itself, it is in reality supporting the surreptitious progeny which Mother Ichneumon has so cunningly committed to its involuntary keeping.

Thus strangely supported, the infant or grub cuckoo-flies attain their growth, and so, to all appearance, does their unfortunate fosterer, the caterpillar. According to instinctive custom, the latter, then deserting its cabbage, betakes itself, perhaps in July or Angust, to the sheltering coping of a garden wall, or cross-bar of a paling; places where, in the 
common course of nature, it is accustomed to discard the caterpillar and put on the chrysalis form. But Nature has, in this case, been ovcrruled (we may be certain, as always, by the wise permission of her Great Master), the tiny ichneumon having been employed as the agent of her defeat.

We have happened, perhaps, to see a caterpillar, visited as just described, ascend its wall or paling. In a day or two, perhaps in a few hours, we see it again, still a caterpillar, and alive, but reduced almost to an empty skin, while heaped around it is a mass of little oval cocoons of yellow silk. By some people these might be taken for the catcrpillar's eggs; by others, for a specimen of its own spinning; and they might suppose, moreover, that it had worked so hard as well-nigh to work itself to death; but no such thing-the yellow silken cases have been spun by the little brood of parasites, which, having simultaneonsly deserted the poor shrunken body of their fosterer, have thus shrouded themselves for safe attainment of the winged perfection which she (poor blighted promise of a butterfly!) is never to attain.

One most noteworthy circumstance in the above and other parasitic infestations of a similar kind, is the avoidance, by the ichneumon devourers, of every vital part of the caterpillar deroured, whose living juices are requisite for their support.

Incipient moths, as well as butterflies, are continually being defrauded of their winged estate through the agency of ichneumon, and sometimes other parasites. 
The black and yellow "Magpie"* of the currant, while in the form of a black and yellow caterpillar, is often to be seen in the same wasted predicament as its fellow-sufferer of the cabbage, and, like that, surrounded by the silken cocoons of its destroyers: or, supposing it arrived at its second stage, that of a black and yellow chrysalis, its progress is equally liable to be arrested ere it attains its third.

Such a chrysalis we have sometimes gathered with the currant or plum leaves, to the back of which they are often, in July, to be found attached by a slight silken net-work. Our object in thus plucking them from their native trees has been to watch them through the curious process of emergement; but, lo! when we have been looking for a magpie moth, curious to behold, though seen before, the gradual expansion of her large white wings, with the gradual coming out of their black and yellow speckles, nothing has come out at all but au ugly black devil of an ichneumon-fly.

We are not sure whether, in the above instance, the "Magpie's" destroyer first attacked it while a caterpillar, or after it became a chrysalis. Numerous, at all events, are the various aurelian covers which serve only to conceal, perhaps one, perhaps an assemblage of surreptitious lurkers of ichneumon form, or, if differing in shape, of ichneumon habits.

During last August, we had six of the golden chrysalides of the little tortoise-shell butterfly all suspended to a cluster of 
nettles which we had planted in a flower-pot for the provision of their caterpillars. From two of the number appeared duly, in all their bright array of black and scarlet, blue and gold, the insects to be naturally expected; from the third issued a brood of small ichneumons. Of the fourth, fifth, and sixth, the "gold coats" assumed a questionable blackness, and being hence led to examine how they might be filled, we found, instead of the wrinkled wings and folded members of butterfly occupants, three little brown barrels within each, which we presently recognized for the pupæ of two-winged flies; and from these accordingly came forth nine as ordinary-looking little animals of that description as were ever set eyes on buzzing in a window,-distinguished, howerer, by their parasitic origin from the household herd.

The see by the above instances, which might be multiplied by hundreds, how precarious the prospects not only of the future moth or butterfly, but also of the expectant collector; and let not the tyro in their pursuit vainly flatter himself that, because the chrysalides he possesses may have been exhumed from earth, and are still buried in his boxes, or are enshrouded in silk, or encased in wood, they are slumbering in safety to adorn his cabinet; for vain, in numerous instances, will prove the caterpillar's ingenuity, and labour, and instinctive care, and vain, also, the collector's every precaution to guard against the intrusions, somehow and at some time effected, of the insidious race Ichneumon. 
Even with a group of insect eggs, guard them as we may, we can never be certain that some parasitic occupant has not possessed them before ourselves. Kirby tells us of ichneumons so minute as to occupy, between two, one egg of a butterfly; and Bonnet speaks of the same confined receptacle as affording board and lodging to several of these tiny interlopers. When told that out of sixty eggs of the emperor moth, not one was found exempt from their intrusion, we may imagine the large proportion of caterpillars nipped in the embryo, as well as in their growth, by parasitic enemies. Amongst these, all are subject to attack by similar destroyers of various size proportioned to the bulk of their victims, from the minute grub of the leaf-miner, to the bulky caterpillar of a puss-moth or a sphinx; and commensurate with this wide extent of damage to the caterpillar crew, is, of course, the benefit to the vegetable world and the human race, through these parasitic agents, which, while emblems of evil, are thus made instruments of good.

Though the gay and beautiful order Lepidoptera thus holds a dangerous pre-eminence as an object of parasitic attack, it is not alone the butterfly and moth which are often robbed by the same agency of their last estate and brightest inheritance.

We have seen already how a common ichneumon, with a tail-like ovipositor of prodigious length, is accustomed to assail, in the deep nest-hole of a mason wasp, the infant progeny of an insect of its own order, that of Hymenoptera ; and 
we shall briefly notice, now, the invasion of an infant asylum of somewhat similar construction, wherein, however, a parasitic wasp is the aggressor, and a solitary carpenter bee the maternal guardian, whose cares are often rendered nugatory by its cunning.

The waspish lady (in this case the agressor) is, however, we can tell you, Reader, a wasp of no common order; but one which, for beauty and splendour, has never met her match in the waspish world, nor her superior, perhaps, in the whole world of British insects. You must surely have sometimes seen lier, a perfect living jewel as she is! with head, breast, and shoulders all thickly set with emeralds, outshone only by the ruby-red and burnished gold which mingle in her fiery tail. You must have seen, and certainly have noted, such a notable as this, when alighted, according to her wont, in the hottest summer sunshine, upon posts and railings; but you may not know her by the names either of "Chrysis," of "Golden Wasp," or of "Ruby-tail Fly ;" or even if you know her names, you may not be acquainted with her business-her business, that is, upon posts and railings. Never suppose that she so often visits these uninviting, flowerless, dry localities, merely to bask in the sultry sunbeams, or challenge them to outshine her golden splendour. No; this creature, in her glorious array, is bent on glorious mischief. You may, one day, happen to perceive, on the same post as that chosen for her station by the golden wasp, a hole bored in the wood, and 
you may also possibly see its borer, in the shape of a little bee mother, of the carpenter craft, who with infinite pains and labour has chiselled out with her jaws a nursery tumnel, divided it into cells, and stored it with provision for her you 'g. But, ah! that bejewelled ruby-tailed pryer has also watched her in her tender labours, which she will take good care to convert, if possible, to the benefit of her own waspish offspring. Only behold her (like a fiend in angel's guise) lurking to effect her purpose. She has deserted her sunny post, and hides her glittering form under the covert of some neighbouring leares,--her glowing eyes fixed, though, all the while, upon the nest of her humble cousin Bee. She has seen her return, her thighs laden with the golden pollen which she has been collecting for her nestlings' store; but still, it wants completion, and she (poor busy mother!), meaning shortly to return, repairs once more to a neighbouring garden, to load herself again with sweet provision. But no sooner does she issue from her nest-hole, than the wily parasite darts from behind her screen, her dazzling body and glittering wings flash for a moment in the sun, then suddenly are lost in the dark perforation of the tunnelled bee's nest. Woe then to its hapless tenants! They may feast awhile upon the sweets provided by maternal care; but they will feast and fatten only to be devoured by a grub of the golden wasp, who, in her visit to their nest (fatal as it is brief), has deposited an egg, or eggs, from whence will issue all this murderous mischief. 
While the infant bee, deep in its perforated cell, is exposed to dangers such as these, the embryo gall-fly sleeps not a whit more safely within its pulpy or woody globe, pierced, often, to the centre, by the egg-inserting instrument of a gall ichneumon. Even the little aphis, or plant-louse, cannot escape, through its minuteness, from the punctures of an ichneumon parasite proportioned to itself ; and the aphides' archenemy, the ladybird, while yet an aphis-eating larva, is preyed upon in turn by a parasitic consumer.

The student of insect economy will meet continually with resembling instances of parasitic usurpation, at which, till acquainted with its true character, he may often be disposed to wonder almost as much as the early naturalists. Some of these, not a little puzzled by such strange procedures as that of an ichneumon from the egg of a butterfly, or from the nut or apple of a gall-fly, attributed the mystery, for which they wanted a key, to the occasional insufficicncy of Dame Nature's producing power, causing her, at times, when she had planned a magnificent butterfly, to turn out only a vulgar fly.

All the parasites above noticed, if not ichneumons, are, be it remembered, flies-parasitic flies,--either four-rringed, of the order Hymenoptera, or two-winged, of the order Diptera. They are all, also, when arrived as perfect insects at their winged estate, liver's upon vegetable food, - for themselves, usually, mere harmless sippers of honey. Only in the parental character are their cruel and parasitic propensities developed, to be 
exercised either on living subjects, affording at once a cover for their eggs and nourishment for their young, or else upon those stranger nests wherein is to be found both shelter and a store of living prey suitable for the same purposes. The sufferers in these cases are all also immature, being still either in the first or second stage of existence.

But there are certain other insect parasites (chiefly wingless, and of the order Aptera) which are parasitic entirely for themselves,-perfect insects which infest others, perfect also. Of such are the Acari, or mites, with which all, who have ever noticed the commonest of black beetles, must have sometimes seen them covered, as well as their pretty cousins the gold green chafers of the rose. The humble bee is another not un. frequent sufferer from somewhat similar infestation, which is said, moreover, to rob, occasionally, the merry grasshopper of his juices, if not of his enjoyment. 'These, however, with other parasitic tormentors whose visitations extend to bird, and beast, and man, may be looked on more properly as a part of the vermin crew, not now the subject of our notice.

Enough, too, of insect preying upon insect. But before we have done with parasites altogether, we must say a concluding word or two of insects as now and then preyed upon by plants. We are told by physiological botanists, that plants with few and small leaves depend chiefly for their food upon the soil ; those with many and large ones, more upon the atmosphere; and in the Chinese air-plant we have the phenome- 
non of a vegetable living entirely on air. There are also vegetable parasites (such as the dodder, \&c.) which are supporterl solely at the expense of other plants. But who would expect to find in a vegetable an appropriator of animal food, and that from an insect subject? I I t such would seem to be the case with several Cryptogamous, or mushroom-like plants, which have been found growing, in Guadaloupe, on wasps, * also upon hawk-moths and chafers. $\dagger$ These regetable parasites begin, it is said, their destructive operations on the bodies of the living animals, and continue them, like the grubs of ichneumons, till their victims' death.

In our own country, bees and humble-bees are supposed, sometimes, to have a species of mucor, or other fungi, growing on them, though it is thought, by some, that the adhering stamina of flowers may have been mistaken for such parasitic sprouts. By Mr. Kirby these vegetable parasites are considered to arise from moisture, which, accumulating on the insect while in a state of torpidity, may afford thus a bed or seed-plot for these mushroom-like excrescences of a diseased nature.

We began our sketch of parasitic insects by pointing to their moral analogy with parasitic vices; and now, having traced, though slightly, the round of their vampyre-like proceedings, we will only take notice of one other resembling feature, thereby suggested, which will serve, at least, to make * By Mr. Ricard. $\dagger$ By Dr. Mitchell. 
both ends of our subject meet. What are the prevailing characteristics of those animate receptacles which we have seen to be chiefly selected by the prying ichneumon for the fatal in. trusion of her eggs? What but sensuality and inertia? as exemplified in the crawling devouring caterpillar or the dormant chrysalis. And do not these creatures represent exactly the very states, the moral soils, wherein the seeds of vice are usually introduced by the sower of evil? Thus does the Book of Nature teach us, in living characters, what our books of copy repeat so often, that "Idleness is the root of all evil," or, in the words of an old moralist, "The broom that sweepeth clean all good thoughts owte of the howse of the mynde, making it fitt to receave the seven devills.”*

\section{* 'Nugæ Antiquæ.'}

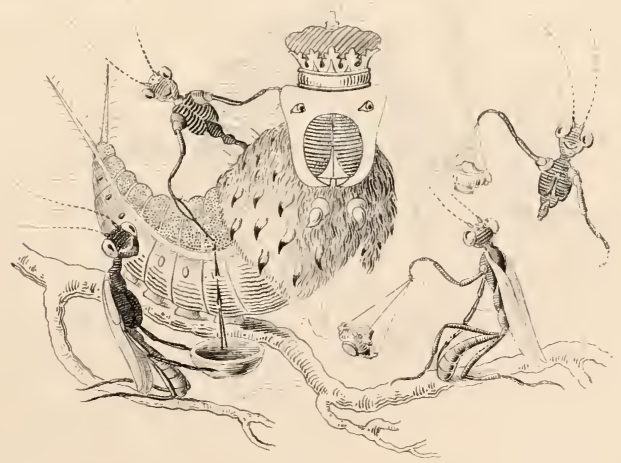

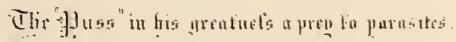




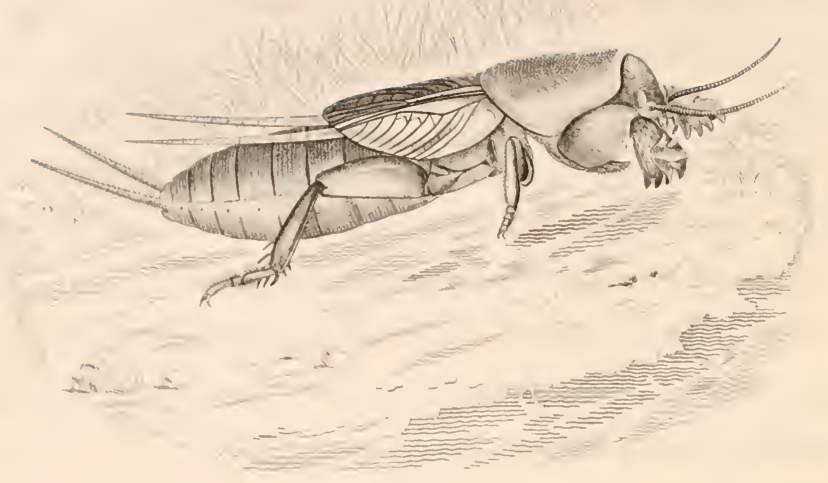

\section{JACK O' LANTERN IN ARMOUR; OR, TOMBSTONE TIM.}

A COUNTRY TALE.

"Pale lights upon that tomb were scen, And miduight roices heard to moan." --Scorr.

The church of our native village stood upon a high eminence overlooking a marshy valley; the village itself being a good mile distant, seated on the opposite bank of a narrow stream which wound through the damp meadows intervening. Although most decidedly a country church, and a very old one, there was a something about ours which gave it anything but 
that air of snug, peaceful rusticity, usually belonging to such edifices. True, it had its venerable yew-trees, and its ivymantled tower ; the latter composing, in fact, nearly the entire building; for the original body of the church having fallen to decay, its place had been supplied by a very small, barn-like erection, so low, and so disproportioned to the massive fragment it adjoined, as to be almost lost amidst the high and numerous surrounding monuments.

Such was the spiritual watch-tower of our parish; but, truth to tell, it was only rarely that the voice of our spiritual watchman was heard resounding from its walls; for once a fortnight only was his cry uplifted, and that in no very awakening strain, in the ears of the few souls which then gathered together, serving to animate (but only by halves) the little cold body of our neglected church.

The churchyard was in keeping with such an edifice; -in other words, nothing could be worse kept. The cutting blast of winter was the only scythe that ever mowed its graves, or swept its moss-grown pathways; but, in truth, from yellow leaves they hardly wanted clearing, for one solitary stunted elm was the only deciduous thing which told in autumn of departed springs and summers, except the graves of children and of those who had been gathered in their prime.

No wonder that our village churchyard was no favourite resort, and that its odour of sanctity was not inviting. No wonder that few by choice would pass through it after dusk, 
and that those who were so compelled had at times heard strange sounds and seen strange sights. Though thus lonely and deserted, never, by all accounts, was resting-place so unquiet; and there was one tomb, in particular, held in the worst possible repute. This, which was by far the most ancient and conspicuous monument of the whole mouldering assemblage, was that of a certain knight, who bore, in the reign of our eighth Harry, the unknightly appellation of Timothy Tomkins. It had once stood within the body of the church; but after that had fallen, and been replaced by the little modern substitute before mentioned, Sir Timothy and his Lady - at least their representatives lying in cold state outsirle the tomb-were fairly (or foully) turned out of doors.

In revenge, perhaps, for this insult paid to their mortal remains, strange pranks were said to be plared at the midnight hour by this ancient couple; but, according to the legend of the tomb, the disquietude of those to whom it was erected had its origin in causes much deeper and more remote.

If correctly represented in their monumental effigies, never were pair worse matched (in outward figure) than Sir Timothy Tomkins and his spouse. The knight was of size diminutive ; except his head, absolutely dwarfish; and with a protuberant shoulder, which emulated the tuft of Prince Riquet. His lady, on the contrary, was carved in fair proportions, showing, as the two lay together, like the smooth felled trunk of a poplar, "tall and straight," by the side of a 
dwarfed, and stunted, and distorted yew-tree, or oak pollard.

As the story went,- - the lady, bound against her will to so unsightly a yoke-fellow, come of a stock also much inferior to her own, tossed the yoke altogether from off her fair proud neck, and, when Sir Timothy, who in a little casket carried a bold big jewel of a heart, was away on military service, showed favour to a handsome paramour. The little knight, who loved his lady, and was nothing prone to jealousy, was said to have stolen away from the English army, then engaged in border warfare, riding fast and far one summer's night and day that he might innocently surprise his lovely dame. On the eve of St. John he arrived at home, where his presence was of course something less welcome than he fondly believed. The lady, however (her first confusion past, and entirely overlooked), cheered the heart of her little lord with unwonted smiles. In lover-like guise she walked with him by the midsummer moonlight, beside the winding stream, overlooked, in those days, by the knight's stately halls, as in these by his stately tomb; and there, in the midst of her basilisk fascinations, gave him, with her own fair hands, a treacherous push into the water, from which, encumbered by his armour, he never rose. None but the cruel lady, her paramour, and a single page, intimidated for a time to silence, ever knew of Sir Timothy's stolen, ill-starred visit to his home; Rumour, with her thousand tongues, assigning as many false causes for his 
sudden disappearance. His widow, whose lover was soon afterwards killed at Flodden, mocked the memory of her hapless spouse by numerous masses and a stately tomb, to which ber own name and effigy were afterwards appended.-So went the tale.

Though generally neglected by day and avoided by night, there was one inhabitant of our village by whom the old church, churchyard, and, above all, the Tomkins' tomb, were once regarded with a reverence and love which cast out fear. This was an old man named also Tomkins, then sexton of the parish, and cicerone to the parish church, which, on account of its high antiquity, was now and then visited by persons of antiquarian taste from an adjacent watering-place.

Old Tomkins remembered the church in all the integrity of its ancient body,-remembered the Tomkins' monument standing under the canopy of a fretted roof, when (as the very gem of his sepulchral cabinet) he used to exhibit it to strangers, and relate its gloomy legend, cmbellished by himself, and all with a pride in nowise lessened by the coincidence of his own family name with that of the murdered knight; and it was, perhaps, chiefly to encourage and keep up the notion that he was descended from the same stock, that he was proud also to borrow the christian appellation of Sir Timothy for the first little grandson (also godson) who came into the world to receive it.

But somehow or another, the ill-fated little knight's name seemed to carry with it its fatality. Father, or mother, the little 
Timothy never knew, having lost both while in his cradle; wherewith he was transferred to the roof of his grandfather, the sexton. Partly, perhaps, as the inheritance of a consumptive mother, partly from the bad nursing of an ill-paid hireling, the boy soon showed symptoms of a weakly constitution, followed by deformity and stunted growth,-afflictions, especially the latter, whereby he acquired one point of personal and increasing resemblance to his knightly namesake, and with it also a fresh liold, not only on the love, but even on the pride of his grandfather.

So long as the old man lived, the orphan never felt the want of a mother's love or a father's protection. He, the little Tim, and the great monument of Sir Timothy, were the two things on earth to which the old sexton's heart most fondly clung. The decaying tomb which it was his pride to keep clear of moss and weeds, and the sickly child whose fragile life was hardly supported by his care, seemed in his mind to be more closely connected than by name. All the orphan knew he had learnt from his grandfather, who, playing the schoolmaster after his own fashion, had taught him first his letters, then his lessons, from the tombstones; and rewarded his diligence by telling him, as they sat together in the churchyard in summer, or over their scanty fire in winter, tales of wonder, all gathered from the graves; at the head of which, and engraven by repetition, there always stood foremost the legendary story of Sir 'limotlyy and his wicked lady. 
No wonder, with such teaching and with such almost sole companionship, that as years went on and the aged man sank down towards second childhood, the sickly, decrepit child seemed to grow up (though he grew but little) into old age. In countenance, in step, in speech, he was never young; he was as unable as unwilling to join the sturdy villagers in their joyous sports ; and when, on rare occasions, he chanced to come among them, although he was as gentle and harmless a creature as ever drew breath, the timid of the crew would keep aloof and eye him with distrustful looks, while the bold and bad jeered at his deformity, and gave him the nick-names of " $\mathrm{My}$ Lord" and "Tombstone Tim."

When about fifteen, Tim lost his grandfather,-his only friend. The office he had performed for so many, another did for him ; the lowly bed of the late sexton being made, by his own particular desire, between that of his son and daughter (the orphan's parents) and the grand old monument which had been the pride of his life,- - at all events, of his latter years. All through the progress of his gradual decline and last illness, poor Timothy had been the sole and tender nurse of him who, through the previous course of his own feeble, blighted days, had been his only supporter; and the thin, weak, effeminate hands, unfit for the mattock and the plough, were well suited to prop the head and smooth the pillow of declining age.

For the last fourteen years,-from the period nearly when his orphan grandson had been thrown upon his charge, old Tom. 
kins had been in the habit of consigning to a little box all the odd shillings and sixpences given him from time to time by strangers to whom he had shown the church and monuments; and though of late hardly pinched, nothing would tempt him to take a penny from this little hoard, which he had set aside as the orphan's portion.

The casket in which the good sexton kept this precious treasure was suitable to his calling, as well as to the means by which it had been got together. It was a small oaken box made out of the fragments of an old coffin, and rudely carved in imitation of his favourite Tomkins' Tomb. An hour or two before he died, he put this box, with its contents, amounting then to eleven pounds three shillings and sixpence, into Tim's hand; and gave him, with his last blessing, a charge (though this was little needed) to keep in decent order three humble graves,- - those of his young parents, with that of their old father so soon to be dug beside them; and, above all, never to neglect the ancient monument of lis namesake, Sir Timothy Tomkins.

Though the orphan boy felt, desolately, that with his last relation and friend he had lost the only home of his solitary heart, he still continued to abide beneath the roof under which he and his grandfather had, as lodgers, occupied a room for many years. The old woman whose miserable cottage they had shared was still glad enough to receive from the boy the weekly stipend so long paid by his grandfather, with an addition for 
his board, which did not witness very highly for the nicety of her conscience. But hard as was the impost-harder, too, than poor Tim knew for-he contrived for some time to defray it out of his own earnings, without having to lay an abstracting hand upon his little legacy in the "Tomkins' Tomb," which it was his pride as well as prudence to keep as long as possible untouched.

For some years he had got occasional employment in tailoring; and now that he liad no longer to attend upon his helpless old relative, he stuck closer than ever to his sickly occupation.

It was early spring-time when old Tomkins died; but it was only from the window of the little garret where he sat and plicd his needle that Timothy could breathe the sweet morning air, or listen to the love-song of the birds. From this window, however, which looked towards the church, he could distinguish the Tomkins' Tomb as it towered abore its fellows; and his eye, thus guided, could rest exactly on the spot adjacent, where lay the three graves of those to whom he (who had now none to love him) had once been dear. And to this spot, when crening came and released him from his sedentary task, did he constantly repair; and while other youths of his own age, strong, and healthful, and hopeful, congregated to play at cricket on the common, or repaired, by twos and threes, to fish in the stream, or to shoot rooks in the tall elm-trees near it, poor Tim was to be seen climbing slowly and painfully up the 
steep pathway which led to the lone churchyard; and those who took the trouble to watch him further could always discern the outline of his slight, deformed figure, seated close by the great monument, as that, and every object on the hill's summit, rose clearly defined against the western sky.

Hours later, the few who passed hurriedly through the ill-reputed cemetery would be sure (whether they knew it or not) to have at least one living companion within its gloomy precincts, in the person of "Tombstone Tim." Some had seen him there by the light of the moon-some by the glimmer of the stars-and others declared, with a mysterious look, that when all the sky was dark, they had seen him quite as well by the blue glare of the dancing corpse-lights, which were vouched by many to illuminate, after a certain hour, the monument of the murdered and the murderess.

As stories such as these mixed up, in strange association, our poor young Knight of the Shears with the supernatural terrors and legendary crimes connected with his departed namesake, the Knight of the Spurs, he got looked on by the simple villagers with more than ever of suspicious repugnance. No one could deny that he held communion with the dead;-not alone his habits, but his very looks bespoke it. Since the old sexton died, his face had been growing paler-his large eyes more sunken - his thin hand more transparent-his husky cough (a churchyard cough in verity) more hollow. All shrunk from his presence: the young, because he was so 
unlike themselves-the old because he forced them to remember the place to which they were hastening. But the youth seemed likely to precede them. His daily labours, so close and solitary-his evening rambles, so late, so damp, and dreary, acting on his feeble frame, were not without their inward effects as well as outward tokens; and he grew so much worse that he was obliged to give up both his work by day and walk by night, and, what he thought worst of all, to open his strong box-the mimic Tomb of the Tomkinses-in order to satisfy the demands of his old landlady, now further augmented by her charges as nurse. As for doctor, Tim had none; and, owing perhaps to this deficiency, he once more rallied, and, as the days lengthened, seemed to gain strength and spirits in proportion. He was quite able, he said, to resume work; but this was now easier said than done, for the village tailor, by whom he had been employed, had taken an apprentice during his illness, and no longer required the services of his late assistant. Timothy was not, however, utterly cast down. Of his monumental remains were still left the sum of four pounds, and he determined (if possible) that this should not be reduced much further.

One fine morning in June-it was that of St. John's dayhe set out very early, that he might walk, often resting by the way, to the nearest market-town, about four miles distant, to make inquiries after a new employer. After many failures, he at last succeeded in meeting with a master-tailor who, being 
short of hands, promised him work for at least several ensuing weeks; and, after staying for a few hours to produce a satisfactory specimen of his handiwork, poor Tim, towards evening, wended his way homewards, with a lighter heart than had once been his since his last old friend had been taken from him.

The balmy air, the evening calm, the hay-fields through which he passed, and where his rest upon the hay-cocks seemed a sweet elysium,-all these common enjoyments, which yet to him were rare, had a healing effect upon his wounded spiritnow, too, under the reaction of recovery from sickness; and, without pointing to a single defined object, hope seemed, for once, to have taken him by the hand.

When he reached home he found his landlady at her supper, of which she more graciously than usual invited him to partake; and when Tim showed her his bundle of work, and told her his success, there was an appearance of satisfaction in the old woman's wrinkled forbidding face, which looked so much like interest and sympathy, that it went direct to the heart of the poor friendless lad. At that moment of unwonted hopefulness he could less than ever suspect aught of ill, and, crabbed and hard and grasping as he had ever found her, he tried to think that, after her own peculiar fashion, she was, after all, a friend to him. Wishing her a kind good-night, he soon went up to his garret, meaning to go to bed early, and yet earlier to begin the work he had brought home. But before going to rest he had a little business with the Tomkins 
Tomb,-not (this evening) with that in the churehyard, but with his grandfather's miniature model of the same.

He had reluctantly subtracted in the morning from his four pounds remainder, two shillings, with one of which he dis. charged his only debt to his landlady, putting the other in his pocket with the key of his treasure-box. Now this shilling, which he had brought home again, he thought he would return to where it had been so long entombed, and, with this intent, looked for the oaken box, in the cupboard where he had inadvertently left it. To his surprise and consternation it was gone. He rummaged despairingly and vainly in the few other hiding-places his little room afforded; but it was gonequite gone!

He hastened down to tell his loss to the old woman. She was gone too-out to a neighbour's; and in an agony of distress and impatience Tim was turning to remount the ladder stair, and look again where he had vainly looked before, when, on passing close to an old walnut-tree chest of drawers, which occupied one corner of the kitchen, he nearly stumbled over something on the brick floor, and on picking it up found it to be a bit of his missing box-one of the carved pinnacles from off a corner of the miniature tomb. The blood rushed for a moment into Tim's pale face, which then grew paler. It was she, then, his firend, who had robbed him of his little all!

He trembled, and, quite overcome by alarm and vexation, following on the fatigue and excitement of the day, sank into 
the dame's arm-chair ; and there, with the bit of wood still in his hand, sat waiting, yet dreading her return. But she came not; and after an hour spent in a fever of distress, and uncertainty what to do,- -trying against conviction to think the old woman innocent, and not bearing-scarcely daring-to tax her with guilt,-too restless to sit there longer or return to his own chamber-or to endure within doors the sultriness of that midsummer night-Tim, without reaching down his hat, hurried from the cottage.

He had not been long gone when the old woman returned. The moon being late, it was nearly dark when she came in; and soon after her cuckoo clock struck ten. This was an hour after the time at which she had been generally accustomed to go to bed-always in the summer-time without a light;-but on that particular evening she loved not the darkness.

If she had been a fine lady she might have fancied herself nervous; being only a poor creature, she felt herself queerdreading she scarce knew what, and trembling she would not know why. With shaking hand she plied her steel and tinder —was long in kindling a light-and, when she had succeeded, thought it burnt blue. She had gone out partly for the sake of other people's company, and, now she was at home, did not like her own. To improve it, she thought for a moment of calling in the aid of a certain domestic spirit (the only spirit she did not dread) encased somewhere in the walnut-tree chest, which consisted, besides the drawers, of a sort of cup- 
board ; but something withheld her, and, as if afraid to move, she sat crouching in her great arm-chair. On that night her old deadened senses seemed all at once restored to more than youthful acuteness; but solely for her torment. She generally troubled others by her deafness; but she was now troubled herself by excess of hearing. The monotonous ticking of her clock, though it seemed louder than ever heard before, did not drown the tapping of the death-watch which came at intervalstick, tick, tick-from the bottom of the walnut-tree drawers. Her sight, by day, was very dim; but by the glimmer of a rush-candle, and without spectacles, she saw,-and as she saw it her blood curdled on that midsummer night, and her knees and toothless jaws both knocked together-she saw-plain as she had ever done at noonday-gliding in at the closed door, the figure of the old sexton, her thirteen years' lodger, wearing the same brown coat and red handkerchief in which she had last seen him in that kitchen, before he took to the bed on which he died. Silent, and without a sound, the apparition passed her, and stood (she knew it, though she could not see it) by the walnut-tree chest behind her chairthat chest which his own hands had fashioned for her use. But what was his business with it now? What had he come to find? She had the key in her pocket; but she heard it turn in the locks behind her. She heard and saw no more ;fear, which had seemed to sharpen, now benumbed her senses.

* $*$ * $*$ * $*$


During the early part of her terrible vigil a wandering thought would now and then cross the mind of the old sinner, that if she lived to see the morning she would restore the orphan's stolen treasure; but as the paroxysms of her palsied fear grew more violent, this resolve, if such it could be called, became more vague, and, when fear had reached its height, was lust altogether in unconsciousness. By the time the birds began their morning twitter, the dame had, in some degree, recovered; but her mind, tinctured before with age's imbecility, lad been hurried by the terrors of that night to the very verge of fatuity.

At the voice of the milkman, and the clatter of his pails, she hobbled to the cottage door, but without the mug, in which, for her own and her boarder's breakfast, she usually received her quarter-pint.

"I say, dame," said the man, on her returning with the milk-pot, "where's your young snip, Tombstone Tim?"

It was a strange question, that. Who had ever before thought, or cared, or asked about poor Tim?-and the query was put with a look of meaning which seemed to say that the inquiry was made for something more than merely to receive information. The old woman might have had perception enough remaining to notice this; but whether she had or not, she by no means liked the question, and it was repeated twice before she answered, "Tim? why, lauk-a-day, he's a-bed, I suppose."

VOL. III. 
Perhaps she really thought so; but the milkman wouldn't let her rest. " $\mathrm{Ah}$ ! but do ye know where he was last night? 'cause if ye don't, old gal, I'll tell ye."

"Where?" cried the dame, eagerly clutching at the unan's jacket with her skimny hand.

"Why, may be I'll tell ye, may be I won't," said the young fellow, enjoying her anxiety. "Well, then, he was up yonder" (pointing towards the churehyard) ; "that's nothing by common, to be sure; but there was something else last night very particklar besides. I can't say I seed it myself, but Joe, my brother, did, and that's the same, as he was a-coming home just on twelve o'clock, from Farmer Jones's hay-harvest supper. Well, as he come through the churcliyard, he tried (he says) as hard as ever he could to turn his eyes right away from little Sir Timothy and his big wicked wife; but somehow, for all that, he couldn't help seeing them, all in the light of a power of them corpse-candles as danees about the old moniment. Plenty, to be sure, has seed them afore; and there, close by, on old 'Tomkins's grave, sat Tombstone Tim-and that was nothing out of the common either; but what do you think, dame?"- (and here the speaker laid hold of his auditor's shrivelled arm) " what do you think? a-sitting close aside the little atomy, with one hand on his hump and t'other round his bit of a body, quite fatherly-like, as he used when he was alive, sat old Tomkins hisself, in his brown coat and red handkerchief. And now I'll tell ye something else"- 
The blue watery eyes of Dame Huggins were fixed intently, though vacantly, on the narrator of this tale of wonder; and the diminutive milk-pot, held in her shaking hand, was fast shedding its contents on the threshold of her door, when the sound of many voices-to which, however, the listener seemed deaf-suddenly arrested the voice of the speaker. Just then, turning into the village from the meadows between that and the church, appeared a little crowd of people, who, making their way towards the cottage, rapidly approached.

At the head of the party came a tall strapping fellow, whom the milkman presently recognized as his brother Joe, the ghost-seer of the previous night. This man was the bearer of some burthen,-of what nature was at first indiscernible; but it soon became evident, as he drew near, that he was holding in his arms, with as much ease apparently as a woman bears an infant, a seemingly lifeless body. The group stopped when it reached the door of the cottage, where for a moment we must leave it, to account for its arrival.

Joe, having slept off his panic of the previous night, had repaired early that morning to the meadows to cut grass by the side of the river, which was at that time low. By that part of the stream which wound below the church hill, he had perceived, half-way down the bank, which was there steep and rugged, a crutch-stick, and being led by this to look further, discovered lying below, half in the water, half among the rushes, the person to whom evidently the stick belonged. He 
had fallen on his face; but the shrunken figure and misshapen shoulders confirming the testimony of the crutch itsclf-all told at once that it was "Tombstone Tim."

Had it been a stranger in any such predicament of perilany one, in short, but the person in question,-Joe would have been at his side in half a second; but when he saw who it was, a sickly qualm came orer the heart of the stout countryman. In what ehurchyard company had he secu Tim the night before? What had brought him to where lie was that morning? Joe put the two questions together, and gave himself an indubitable answer, to the effect that the ghosts and evil spirits with which "Tombstone Tim" had been so long in fellowship had at last led him to destruction, perhaps entered into him bodily, and driven him down that steep place to perish in the waters.

In such persuasion, no wonder that tall Joe hesitated ere he brought himself into closer contact with one who, if not then, must have been so recently "possessed;" but Joe was a kind, good-hearted fellow; he remembered not alone the parable of the Legion, but that also of the Good Samaritan, and feclings stirring within him stronger even than his superstitious fears, brought him presently down the bank. He called Tim by name, no answer was returned; shook him by the arm, no morement followed; turned him gently over, and saw a white motionless face, with a dark red and blue cut over the cheekbone, received, Joe doubtless suspected, from the hand of 
some ghostly enemy. "The lad (thought he) is certainly dead; but there's no knowing, and I can't leave him here to fetch a neighbour and I able to carry him home myself."

So, though he nothing liked it, and would rather have carried on his brawny back a Daniel Lambert than the shadow of the man now before him, he lifted his light yet onerous burthen, and trudged onwards, whistling as he went to keep up his courage, till, joined on the way by stragglers, he reached the cottage of Dame Huggins. We have already brought him with his escort to her door.

Had he carried such a burthen home to any other house in the whole village, there would have been shrieks and sobs, humry and confusion; but here there were none of these. It was only the body of Tim, the fatherless, motherless, friendless boy who had abode so long like one dead among the living, and spent in the graveyard so much of his existence-living among the dead. 'There was no frantic alarm, no melting tenderness for him ; but among the collected and fast-increasing crowd, there was no lack of conjecture and wonder and words -nor of shuddering fear and even repugnance-as Joe's history of the morning and partly of the night was passed eagerly from mouth to mouth; and while the bystanders were all thus busy with their tongues, not one anong them-not even the women-stirred hand or foot to give aid,-if aid might be aftorded to the unconscious object of all this silly, ganing, heartless curiosity. 
Joe, however, grew impatient under his burthen; besides, he would have had something done even for a devil in distress. For about the twentieth time he called on Dame Huggins to open the door, which was now shut-to behind her; but there she stood with her back against it, looking vacantly on and muttering and smiling. "The devil's in the woman!" exclaimed Joe. "Why, dame," once more he repeated, "why don't ye let us in, to carry the lad, dead or alive, up to his own bed?" But he might as well have spoken to the door itself. Shoving her aside, he tried to open it; but from the outside this was no easy matter. "The window, then !" cried Joe; and calling his brother, the milkman, to his assistance, he and his senscless encumbrance were presently through the low casement, up the ladder-stair, and Tim deposited upon his wretched bed.

What was done next? This is a query which we shall now, perhaps, best answer in our own proper person, inasmuch as we took upon us to do it then, practically, as one amongst the many spectators and few actors in the scene above described. We had been out betimes that morning for the purpose of seeking some early-flying moths, when, returning past the cottage of Dame Huggins, we, fell in with the assemblage round her door, and were, of course, led to augment it, but only just previous to the moment when Joe effected an entrance at the window. We knew little about the dame, except her general character as a hard, griping, cumning old 
woman-a reputed hoarder, yet the most notorious hedgebreaker in the neighbourhood,--and as for her lodger (so rarely abroad in daylight), we had scarcely seen him; though we had heard and often smiled at the popular prejudice which associated, in more than resemblance of name and person, the crippled young Tomkins with the dwarfish effigy on the Tomkins' Tomb. But as we saw him that morning, with his distorted form, his shrunken legs as they dangled powerlessly over the stout sinewy arm of his athletic bearer, which more than equalled them in size-lis pale face resting on the tall countryman's shoulder, looking paler as contrasted with a countenance ruddy with health and exercise, and more ghastly from the wounded cheek and dark matted hair clinging to the temples, the countenance rigid as in death, and stamped with one expression-that of perpetual suffering, heightened only by accidental pain;-as we saw the poor youth thus, our heart smote us for not having seen and known more of him before. Ah! it told us, then our butterfly rambles and researches occupy us overmuch, and have made us think too little of this our afflicted neighbour! But this was a time, not for thinking, but for acting; and, seeing there was no one of all the lookerson disposed to make a single effort towards saving the life which (if not extinct already) hung trembling on a thread, we despatched a boy in the crowd for the nearest surgeon; and finding the old mistress of the house utterly incapable of thinking or doing anything, we took possession of her kitchen 
-roused up the dying embers-employed some of the female neighloours (ready enough, now their first panic was over, to do kind offices even for "Tombstone 'lim") to heat water, warm blaukets, do all, in short, that could be done, in the doetor's absence, for the recovery of the half-drowned boy. But it was not till the surgeon came, and applied means of revival more powerful than ours, that poor Tim once more opened his eyes on the living world, with which he had so little concern. He threw a glance round his usually lone garret, now so unwontedly occupied; but the look seemed to convey no image to his mind, and before night he was in the delirium of a burning fever.

During the course of a long subsequent ilhness, we need hardly say that young Tomkins wanted for nothing in our power to procure him. He could not be removed, but his wretched unfurnished dormitory assumed an aspect of comfort its occupier had never known. One good woman of the village so entirely got over her superstitious fears of "Tombstone Tim" as to attend on him by night as well as day; her watch being, however, not unfrequently relieved by a more awkward but as kind a nurse in the person of "tall Joe," who evinced an uncommon interest in the poor " possessed," whom he had helped to rescue from the Evil One's power.

As for Dame Iluggins, she seemed to have sunk into a state of complete fatuity, though, like a machine, she still regularly plied her daily occupations,-bought from the village shop and 
exactly paid for her penurious provision-gathered and, if possible, stole her sticks-boiled her pot, and crept into her bed. For all other purposes of use or intercourse her mind was what people are accustomed to call "quite gone," though, to judge from her continual mutterings by day and moanings by night, it seemed still-much to her discomfort-to hold within her some sort of uneasy presence. One day, as if by accident, she entered Tim's chamber; but the moment he caught sight of her, he shrieked and was so strongly agitated, that good care was taken in future to prevent a repetition of her unwelcome visit. Often, however, in his feverish ramblings did he address her, imploring her to give him back a something she had taken from him, though she might keep, he said, all the money, and he would never tell his grandfather nor yet Sir Timothy.

These incoherent words, with others to a similar purport, often repeated during our frequent visits to his bedside, first awakened our suspicion that the orphan boy had been robbed by his sordid old landlady.

As Tim slowly recovered the powers of his mind, he would often use expressions of grateful regret at his inability to pay anything for all that was being done for him. We, of course, did our best to quiet him under this his honest distress; but, as connected therewith, we learnt the story of his lost treasure, with its casket, the little Tomkins' Tomb; also his reasons for believing them in the dame's kecping; though of this he 
entreated us to say nothing, as he shonld be sorry, he said, for her to get into trouble on his account. We were devising, nevertheless, some quiet means of sifting this matter to the bottom, with a view to recover, if possible, the lad's little property, when we were spared in an unlooked-for manner the trouble of taking any measures for the purpose.

The dislike and alarm evinced unconsciously by poor 'Tim on occasion of Dame Huggins's single visit to his sick chamber, seemed (to jurlge by her subsequent proceedings) quite recip. rocal. Both in the time of the old sexton and since his death, she had always slept in the upper room contiguous to that of her lodgers; but on the very day of the above occurrence she carried her bed downstairs, making her nightly lair thenceforward in a corner of the kitchen; an arrangement which none opposed, as it left her former room open for the more convenient occupancy of the woman who attended upon Tim. One night (it was that directly following the lad's disclosure to us of his loss and his suspicions) he was sound asleep-his murse watching near, or possibly asleep too,-when she was suddenly startled by a loud noise as of a heary fall below. 'Tim started, but did not wake. The woman, listening, thought she heard a moaning, and then, taking up the rushlight, crept softly down the ladder-stairs into the kitchen. There a sight presented itself which sufficiently explained the previous sounds. On the brick floor, near the walnut-tree chest, lay the old woman; and close by the same receptacle 
was placed a chair, on which apparently she had just been standing in order to reach one of the topmost drawers. In one of her hands was firmly clenched a key. She was still showing faint signs of animation; but on an attempt of the nurse to remove her to her bed, life departed with a heavy groan. The key, which even in death had remained locked in her cold grasp, was given to us the next morning by Tim's attendant. It was that of the wainut-tree chest; and no long period elapsed before we were enabled to avail ourselves of this unlooked-for means to ascertain the truth of the lad's suspicion about his stolen property. On the drawers being searched, there assuredly, in the one at top, was found the miniature model of the 'Tomkins' Tomb, with the lock forced off and one pimnacle deficient. There was no deficiency, however, in the remnant of 'Tim's legacy, which, as reduced to the three pounds eighteen shillings he had left in the box on the morning of St. John's day, remained there still; nor was this all, for in the same receptacle was found an old canvas bag, containing a hundred and ten golden guineas-the old woman's hoardings,-and on this was pinned a paper whereon was scrawled, in tremulous, misshapen characters, but sufficiently legible, the inscription — "This is for Timothy Tomkins."

While under a visitation of compunctious fear-perhaps, also, of old 'Tomkins's upbraiding ghost-she had doubtless been urged to indite this compensatory document. To judge 
by the colour of the writing, also by the pewter inkstand found recently used, she hat penned it only on the night of her death, and had probably been attaching it to the canvas bag just previous to her accident. After locking the drawer, perhaps her old head had swum giddily, and, catching at the key to save herself, it had parted from the lock, and accelerated her fall.

It was with no small degree of satisfaction that we took possession of this treasure trove, for the benefit of our young friend, only awaiting a seasonable hour for imparting to him the recovery of his grandfather's little bequest, with the mulooked-for addition of a rich legacy. It may here be noticed, that the tardy justice of Dame Huggins to "'Tombstone Tim" involved no known wrong to any of her kith and kindred, of whom (if existing) nothing was ever heard, or likely to have been diseovered.

It was some time before we learnt from Tim the mysterions means by which he had been spirited away from the churelıyard to the spot below, where he had been rescued from a watery grave. He had never himself adverted to the subject, and we had feared. to agitate his weakened mind and weaker frame by any questions regarding those illusive impressionsperhaps terrors - in which we believed the realities of St. John's night to have had their source. A little incident therewith connected led at last to the satisfaction of our curiosity. 
Almost as soon as Tim had been able to think of anything, he had recollected the job of work brought home from the market town on the morning of his misadventure, and according to his desire it was sent back untouched, with an account of his illness. One day, however, when approaching towards recovery, he received from the master-tailor a message to the effect, that a packet of new buttons given him for use had not been returned with the other articles. Then, and then only, did Tim call to mind, that instead of being wrapped up with the clothes, these had been put, when delivered to him, in his coat-pocket, and, as they were not there to be found, might have fallen out, as he thought, on occasion of his own abrupt descent down the bank of the river. In this case, they might possibly be yet recovered, and however spoilt, they they would serve, at least, as evidence of the manner of their loss and the honesty of the loser. On this occasion the active services of tall Joe were again in requisition; and, on the evening of the tailor's inquiry, he trudged off (after his work) to search the bank, examine amongst the rushes, and sound, as far as might be, the mud of the stream, which, owing to dry weather, was still low.

Just as Joe had departed on this errand we happened to call in on our young convalescent, who told us the history of the buttons, and was led thence, partly by his own voluntary retrospects, partly by a few pertinent queries, to relate to us entire that of his ever-to-be-remembered Midsummer eve, 
beginning from the moment when, in a fever of distress at the discovery of his loss and the old woman's treachery, he had left the cottage. For what purpose did he go? He knew not, except that he could not bear to stay within; and having not a single friend living in the village, or anywhere, to whom to impart his trouble, whither should he bend his steps but to where habit led him-to the place where all his friends departed were assembled-to the churchyard? But let us try to give the substance of lis narrative-if sulstance we may call what seemed composed entirely of shadows-in his own, or nearly his own, words.

"When I got there," said he, " the church clock had just gone nine; it was rather dark, but I could hare found my way blindfold to the old place, grandfather's grave, beside father's and mother's, and close agen the grand moniment. I was sore tired-foot-weary and heart-weary-so I throwed by my crutch and laid me down along the turf. My face was aburning, as well it might, with trouble and with shame, to think that I had lost the last thing as ever he give me-his own work he was so proud oll, and the money he had put by for me-and it was a-burning too with anger (God forgire me!) to think that she to whom he had always been so kind and neighbourly-that she could rob me of my all. But when I laid my cheek upon the grass, all wet with dew, it felt pleasant and fresh to me, and the tears, that wouldn't come before, fell free and soft-like, and the ache at my heart grew 
easier. Oh! I had come out a miserable, forlorn cretur; but as I lay there I felt altogether changed and happy. I seemed to have got home, and to be along with dear friends, who, without my telling of them, knowed all my troubles, and, because they were angels, would forgive me all my faults. I heard the folks a-laughing and shouting as they came home from Farmer Jones's haying supper; but I seemed to feel happier than they; and when I knowed by the sound of their voices and the clapping of the churchyard gate that they had passed through, I was glad to be left alone agen with them as had once cared for me and were loving of me still. And so I laid resting, how long I can hardly tell, when other things more strange but not so happy came over my mind. May-be I had fell asleep and they were dreams; but I don't know-they were much more liker to reality. I don't remember getting up, yet I seemed to be a-sitting instead of laying on grandfather's grave; and, though it was quite dark, seeing right opposite, as plain as in day-time, the grand old moniment. Then, all of a sudden, I thonght the image of Sir Timothy raised itself right on end, and, gliding from off the top of the tomb, came and sat itself down beside me-its cold white face looking into mine. 'Tim, my name-fellow' said he (for it seemed more liker Sir Timothy hisself than only his image); 'Tim,' said he, 'I love thee for the sake of thy grandfather-a fine old fellow who did good service to dead men, and highly respected my name and moniment; but Tim, thou 
shalt do me greater service. He took a pride in preserving youder empty mockery of a tomb; but thou shalt have interred my unburied bones. Nerer yet have they rested in holy ground, or had Christian burial, and therefore do I haunt this scene of my mockery and murder. Y'es, most foully was I murdered, and by her.' He pointed as he spoke to the image of his lady, which was then laying alone upon the moniment. 'But come, Tim, eome! the night is fast waning, and 1 must show you before cock-crowing where my bones are laid.' Is he said that, he rose, and gripped my arm so tight with both his hands, all covered with stone armour, that I felt as if he had almost turned me into stone too; but yet I tried to shake him off, and that, as I suppose, awoke me. I hardly know, indeed, whether I had slept or not-all I had seen appeared so real; but at that moment I seemed to be aware that I was not sitting up, but laying just as I had thrown myself down on grandfather's grave. Then I did get up, and looked round me. I could sce the old moniment before me then, just as usual, with both Sir Timothy and his lady laying at top, side by side; but as the moon had only just got up on the other side of the church, the part where I stood was all in darkness, and the moniment and the images, coming agen the sky, looked as if they were cut out of black marble instead of white. While I was looking, all of a sudden, a rising from the ground, appeared a bright moring light. It was just like the corpse-candles I had seen often enough before, a flitting now here, now there, 
like wandering ghosts, among the graves; but that night there was only one, and it seemed bigger and brighter than any I had ever noticed. For awhile, it seemed to flutter like over the long grass, so that I could see every blade; then on the path, where it showed the churchyard beetles a crawling from their holes; then, high and higher, it rose to the top of the moniment and hovered right over Sir Timothy's stone face; and then I saw, as plain as I can see you now, that he turned his great white eyes towards where I was sitting with a look as if he wanted to remind me of what he told me in my dreamthat is, if it was a dream at all. I expected next to have seen him sliding off the tomb ; but there, all but his rolling eyes, he laid quite quiet. But it wasn't so, however, with the light, for that now suddenly came right up to me, then as suddenly went back,-stood still a minute, then returned as if inviting me to follow, - and follow I felt I must, lead wherever it would. I couldn't keep my eyes from off it; and my legs (lame and weak as they are) seemed to carry me after it of their own accord. I suppose, when I got up, that I must have took my crutch from off the ground, as it was found beside me; but I didn't seem to need it, for away we went-that brave corpselight and I-over the grave hillocks-yet I never stumbledthrough the churchyard-gate; but I don't remember that I stopped to open it, or heard it slam-to behind me,-and away down through the meadows below-all in a mist with the heavy dew-down, down, towards the river. I knowed we VOL. III. 
were getting nigh it-that wonderful light and $\mathrm{I}$,-but go where it would, through water or fire, I felt bound to follow it ; and to the brink of the water, leastirays to the top of the bank, we had got; and the light stood still, and kept hovering over a stump of alder. And there, as it rested, I could see for the first time that it was no common corpse-light after all, nor yet a wandering star; but that it had a shape-the very shape of Sir Timothy hisself, dressed as he lays upon the moniment -and all 'luminated by the glitter of his coat o' mail. I could see even to his hands, all cased in armour, and one of them was stretched out, as he pinted with his finger to the stump of alder just at the water's edge. There was no mistake in what I saw, though it was only for a minute. Then that awful little cretur suddenly fell, and light and all vanished away. I felt myself falling too; a loud noise sounded in my ears; lights, not one, but a hundred, danced before my eyes ; and the next time I opened them, it was here-only in my bed-looking at the faces of strange, kind friends,-yours, good sir, and others that God, of his goodness, has raised up to comfort me."

This was Tim's story. It was scarcely ended, when we heard the sound of nailed shoes upon the stair; a knock followed at the chamber-door, and "tall Joe," returned from his errand of seeking for the lost buttons, stood before us.

There was an air of importance, with a knowing look of satisfaction, in his honest face, and his mouth was tightly 
screwed up as if to keep in some bit of intelligence bursting to come forth.

"So, my lad, you 've found them!" But Joe shook his head, put his hand in his jacket-pocket, dived, and fumbled long, as though on purpose to keep us on the tenter-hooks of curiosity, and at last drew forth a-something-coated with the river mud, from which it had been just exhumed. It proved to be an iron hand,-a small rusty gauntlet, in which something rattled loosely as Joe threw it on the table.

"Oh! it's Sir Timothy's !-the very same," screamed Tim, stretching forward to take it, then recoiling as if with terror.

Without his superstitious awe, but with an interest and curiosity other certainly than merely antiquarian, we took it up for our own examination. It was undoubtedly an iron gauntlet, of the same style and fashion as the suit of armour represented in Sir Timothy's monumental effigy ; and, although the metal was nearly eaten through with rust, part of a skeleton hand of the smallest possible masculine proportions yet remained within.

The discovery of this ancient relic was at least a curious coincidence, following as a sequel on Tim's tale; and the discovery itself was followed up by a further one near the same spot (by the river-side and under the stump of alder) of other corresponding pieces of armour, with other of their wearer's bones. This looked certainly much like a verification of the legend of the 'Tomkins' Tomb, and seemed no less a confirmation of 'Tim's 
dream, and his dreamy chase, led by the phantom light; at least Tim, you may be sure, thought so; and when (as was fitting) the discovered bones, whether of the little knight or of some other little man, were duly deposited in the churchyard, the namesake of Sir Timothy verily believed that he had been made the happy instrument of giving rest to his wandering spirit. Let this have been as it may, there was no denying but that from the hour nearly of young Tomkins' birth there had been kept up a strange sort of comnection between the defunct knight and his namesake of low degree; and even still it seemed existent, for with the poor remains (supposed) of Sir Timothy seemed interred the worst troubles of Tim.

His bodily frame continued, of course, weak, his constitution feeble, and all might read in his prematurely aged face that he was not likely to reach the full age of man-lie had had already the days of "labour and sorrow" which are usually appended to our three-score years and ten. Yet from that memorable night of the longest day, when he followed the single "corpse light," as if it were the star of his destiny, even to the brink of destruction, his hitherto dark and gloomy and solitary life became comparatively bright and social. "Tall Joe," his preserver, continued, ever after, his warm friend and sturdy protector whensoever needed, and became his fellowlodger, with the good woman who had nursed him through his illness, and who afterwards tenanted Dame Huggins' cottage. The fund furnished by that worthy's compensatory 
bequest, with the small remainder of his monumental legacy, was kept up by occasional work at his old employ, and, subsequently, by the profits of a little day-school, which, with some unrequited labour, brought lim also pleasures he had never known. From an object of the children's dislike and fear, he came, as they knew him better, to be one of their respect and love; and this opened his heart to feelings more connected with the sympathies of life, more youthful, too, than ever had been his in his own childish, but most unchildlike days-when his first ideas, his earliest instruction, even his scanty recreations, were all comnected with inmates of the " narrow house," and derived from one of its keepers. Instead of his spectral visits to the churchyard, when only the owls and bats and beetles were on wing, under the cold blighting moonbeams, he loved, when his daily employ was ended, or before it was begun, to seek the woods and meadows, to drink draughts of life in the morning air, and take warm baths in the summer sunset.

But let it not be thought that when "Tombstone Tim" became thus numbered with the living, he ever forgot his reverence of, or duties to, the dead. Amidst the general neglect which pervaded our churchyard, Tim's labours of love were always conspicuously visible upon the three humble sods where rested his parents and grandfather, the old sexton, whose example and last injunction he failed not to follow by the most scrupulous attention to the Tomkins' Tomb. 
“ A strange tale!" say our readers. "We don't believe a word of it." Perhaps not; but, after all, there's nothing so very strange about it, except a little strange coincidence, such as occurs too often to deserve the appellation.

"But the strange light?" What then? Who has not seen or heard of ignes fatui - Jack o' Lantern and his hundred cousins? "Well, but what have Jack o' Lanterns to do with insects?" More, perhaps, than you think of. And now read the following passage, "whereby hangs our tale," and which may serve, moreover, with those who have not read it before, to cast one new light, amongst various others, on Jack o' Lanterns in general, as well as that in particular of "Tombstone Tim."

It is related by Mr. Kirby, that to a friend of his, then (in 1750) a curate in Cambridgeshire, a Mole-Cricket* was once brought by a farmer, who informed him that one of his people, secing a Jack o' Lantern, pursued it, and knocked downthe insect in question. An ignis fuluus is also described by Derham as seen flitting, insect-like, about a thistle, a corroborate observation as to the nature, in some instances, of such a light.

The luminosity of the mole-cricket not being generally known, is no proof of its non-existence, other light-bearing insects being capricious and uncertain in the illumination of their lanterns. The mole-cricket is altogether a rery curious 
creature, and it is recommended by the naturalist Curtis, to those who are fond of petting "mice and such small gear," that they should rather keep some of these singular insects, with a probability of being rewarded for their pains by some interesting discovery as to their imperfectly-known economy, perhaps, also, as to the above point of their supposed luminosity. We might literally behold in it " a meteor tamed," and thus assign to it, with certainty, a place among other natural causes which help to elucidate those wandering lights which have led astray both philosopher and fool. This singular cricket is common in some counties of England, especially Hants and Wilts; and its structure, with what is known of its economy, furnish one amongst instances without number, of admirable adaptation of means to purposed ends.

The mole-cricket is, as its name imports, an extensive, and, where found in kitchen-gardens, a destructive burrower,working underground like a field-mouse, and throwing up ridges, though no hillocks, like the mole. To fit him for this subterranean mode of progression, he is furnished with a chest powerful as a battering-ram, aided by fore feet like those of a mole, hand-shaped, and mailed like a warrior's glove.* His wing-cases are small, but a pair of ample wings cnable him to cleave the air as well as earth; and to the above powers he adds, in the opinion of Curtis, that of cleaving the waters also-swimming by the resistance of the wing- 
cases and chest. His usual food consists of potatoes, with roots of grass and other plants, varied, probably, with the partially carnivorous appetite of his family, by underground insects, as well as flies. The nests of these crickets consist of subterranean chambers, situate most frequently near the banks of rivers. One of these, constructed near the banks of a canal, and laid open by the deep incision of a mower's scythe, is described by Thite of Selborne as " a pretty chamber dug in clay, of the form and about the size it would have been if moulded by an egg, the walls being neatly smoothed and polished. In this little cell were deposited about a hundred eggs of the size and form of caraway comfits, and of a dull, tarnished white colour. The eggs were not very deep, but just under a little heap of fresh mould, and within the influence of the sun's heat." Mr. Remmie notices a difference of colour between the above and some eggs of the same insect in his possession, which were " translucent, gelatinous, and greenish." He observes, further, that, " like the eggs and young of other insects, those of the molecricket are exposed to depredation, and particularly to the ravages of a black beetle, which burrows in similar localities." The mother cricket, therefore, defends her nest " like a fortified town, with labyrinths, intrenchments, ramparts, and covered ways. In some part of these ontworks she stations herself as an advanced guard, and, when the beetle ventures within her circumvallations, she pounces upon him and kills him."** 
Now, ye carpers and cavillers at our story, we assure you, that however far we may indulge ourselves by flights into the realms of fancy, we never knowingly play towards you the part of an ignis fatuus, misleading you by false allusions into the swamps of error regarding the realities of nature.

Supposing the mole-cricket to be really luminous, we shall find in its location, its mode of flight, its coat of armour -above all, in its mail-clad hands of human form-a close correspondence with the wandering "corpse light" of our Tim, who, with the enlargement and heightening furnished by his excited mind, might not very umnaturally have mistaken a mole-cricket for the apparition of a dwarfish knight.

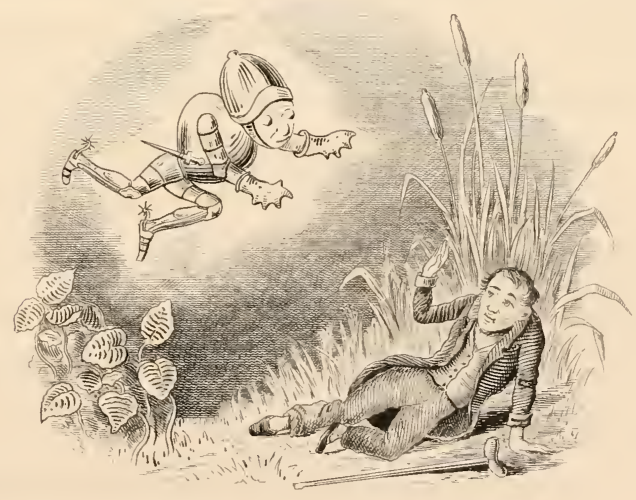

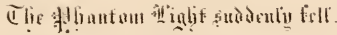




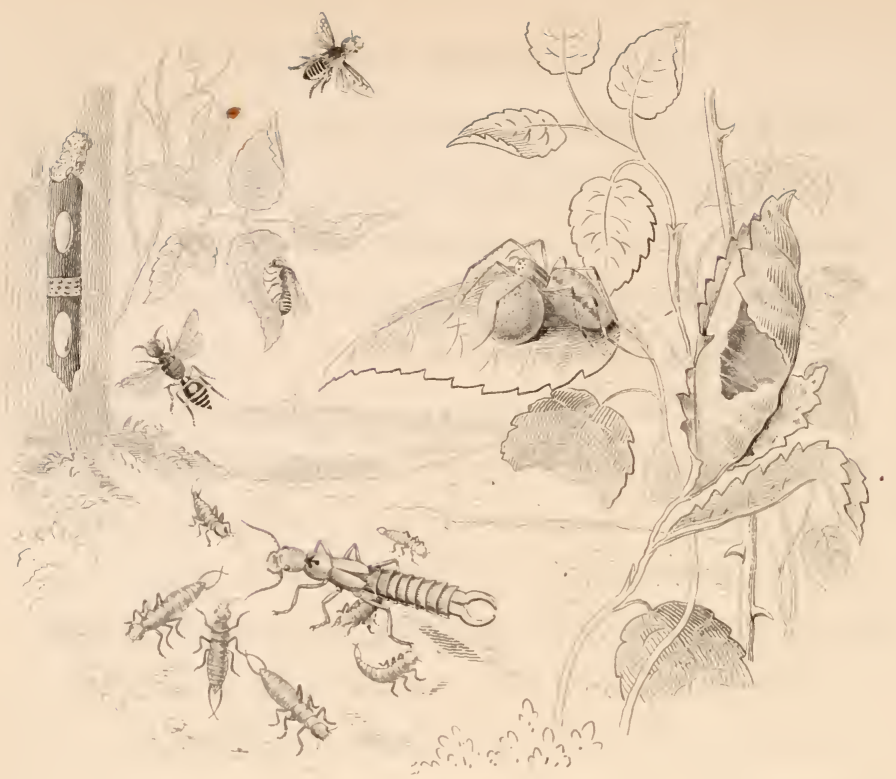

INSTINCTS OF MATERNITY.

THE POPPY BEE

Royal cradles, lined with down, By plume surmounted or by crown!

There's a chamber in the earth, With a cradle in that dwelling,

Furnished for a humble birth,

Yet all your workmanship excelling,

Far as the lily's robe of gold*

Outshone King Solomon's of old.

* The orange or golden lily of the East-the same as that of Guernsey, the roots of which are said to have been first planted by shipwreek on the shores of that island. 
Crimson tap'stry lines the wall, Crimson curtains graceful fall

Round the tender nurseling's bed; And beside it, heaped on high, Luscious food, from flow'rets shed, Waits his wants-a rich supply. Say, by whom this chamber drest? Who can be its looked-for guest?

None but soft maternal care Such a nursery could prepare ;

Yet when the nurseling opes his eye,

Earth alone might seem his mother,

For around, beneath, on high,

Vainly would he seek another:

His is far, in fields of air, While he bursts to being there.

Perhaps she sips her honied pleasure, Forgetful of her infant treasure.

Yet blame her not, ye lady mothers !

She is but a Poppy Bee :

Only mind that ye and others

Do your duty well as she, -

Who, by loving foresight guided,

For her offspring's wants provided.

The implied censure of our concluding lines is one which we really believe few mothers, either lady or lowly, need appropriate; for if there be one virtue more prevailing than another with high and mean, civilized and savage,-nay, even with bad and good,-we should say it was maternal tenderness. What, however, is observed by the worthy Fuller, with regard to the performance of more enlarged charity, may be, in some degree, applicable also to those charities which "begin at lome," and 
flow from that fountain-head of all virtues-a mother's heart. The old divine tells us that " the best disposed [to bounty] may need a remembrance;" quaintly adding, "I am sure the nightingale which would wake will not be angry with the thorn which pricketh her breast when she noddeth."”

Now, as some "nodders" there doubtless are, even on the maternal nest,- some who, possessing, perhaps, all the tenderness of the dove, think it sufficient merely to keep their nestlings warm, and display none of the wisdom of the serpent in providing for their future wants-those, especially, of the hungry mind; to such parents a few patterns of laborious activity exerted prospectively for their offspring's welfare by mothers of the insect race, may serve as gently pricking "thorns," while to others they may be pleasant to look upon as a cluster of wild roses, gathered in a soil which they may have little expected to produce them.

The subject of our opening lines-the Poppy Bee-belongs to one of those solitary, that is to say, not social, tribes which, from their ingenious manner of fitting up or furnishing their nests, have acquired the name of "Upholsterers," or "Leafcutters;" the peculiar designation of "Poppy" being derived from the material employed for her work by this particular species. It is doubted by Kirby and Spence whether the poppy bee is a native of Britain ; but the author of ' Insect Arehitecture** is almost certain of having scen the nests of 
her species in Scotland. We shall give from the latter an interesting description of a tunnelled nursery, formed, and liung, and furnished by one of these little maternal artificers.

" One of these holes is about three inches deep, gradually widening as it descends, till it assumes the form of a small Florence flask. The interior of this excavation is rendered smooth, uniform, and polished, in order to adapt it to the tapestry with which it is intended to be hung, and which is the next step in the process.

"The material used for tapestry by this insect upholsterer is supplied by the flower-leaves of the scarlet field-poppy, from which she successively cuts off small oval pieces, seizes them between her legs, and conveys them to the nest. She begins her work at the bottom, which she overlays with three or four leaves in thickness, and the sides have never less than two. When she finds that the piece she has brought is too large to fit the place intended, she cuts off what is superfluous and carries away the shreds. By cutting the fresh petal of a poppy with a pair of scissors, we may perceive the difficulty of keeping the piece free from wrinkles and shrivelling; but the bee knows how to spread the pieces which she uses as smooth as glass.

"When she has in this manner hung the little chamber round with this splendid scarlet tapestry, of which she is not sparing, but extends it even beyond the entrance, she then fills it with the pollen of flowers mixed with honey, to the 
height of about half an inch. In this magazine of provisions for her future progeny she lays an egg, and, over it, folds down the tapestry of poppy petals from above. The upper part is then filled in with earth.."*

Who but must admire the skill and ingenuity of this little upholsterer? But admirable as is her work, and interesting its design, it stands most distinguished from that of various other insect artizans by the singular showiness of the material she selects for conversion to her purpose. What can be her inciting motive to its choice is a question which, until we can exchange identity for a moment with some poppy bee, we can never expect, with certainty, to answer.

Perhaps the pliability and size of the poppy petal may alone cause her to regard it as best adapted for her intended drapery; but she sometimes lights, doubtless, on other flower-leaves with the same requisites for her purpose, though never, it would seem, converted to it.

Perhaps the poppy's brilliant scarlet may please her taste,an endowment of which, as displayed in their highly-finished and decorated works, the author above quoted considers that insects may not be entirely destitute. It seems, indeed, very likely that, of taste, considered as a perception of the beautiful and the pleasing, insects and other animals may possess a much larger share than man, in his exclusiveness, is accustomed to allow them ; though we alone can boast (and with no great * 'Insect Architecture.' 
reason) of that taste of Protean character, more properly termed fancy.

Her flights of oddity, and whim, and extravagance, and folly - how wofully would they disturb the harmony and beanty, the aptness and simplicity, which pervade and give a divine impress to every instinct-guided fabrication !

To return, for a moment, from our own slight digression to the poppy bee, we have only to remark, that, if " pride of the eye" be consulted at all in her proceedings, it must be that of her own eye only-not that of her offspring's, which, when opened on the darkness of its earth-roofed chamber, can hardly be cognizant of the splendour (even if unsullied) of its scarlet hangings. By other senses than that of sight it is directed, doubtless, to the surrounding honied store maternally provided for its use.

Another industrious member of the "upholsterer" craft, and one which, as a common native of England, may be more easily observed in carrying on her business, is another little bee called the Rose Leaf-cutter.

From June to August, there are often to be found on rosetrees certain leaves out of which have been cut one or more pieces of circular or oval form, and that with as much smoothness and regularity as if with a pair of scissors.* These excisions are, in fact, evidences indubitable that the scissor-like jaws of the bee sempstress have been busily at work, and, by 
watching quietly at hand, it is not unlikely that we may see the industrious little body busy at her cutting out. To follow her as she carries her work home, may be more difficult, at least on some occasions,-but not on all, as her chamber and designed nursery may happen to be in a gravel-walk, an old wall, or an old post, - as likely to be close by as far off. Be it where it may, it consists generally of a cylindrical excavated hole, of which the site once discovered, the interior art and mystery may easily be brought to light by help of a spade or other adapted instrument. In truth, though, to disturb thus the labour of love exercised by this little artizan, would give us pain hardly to be balanced by gratified wonder at the skill and neatness wherewith she has fitted up her leaf-lined nest.

We mean not to say, indeed, (and what lover of entomology would be credited if he did?) that tenderness would be certain, in our own case, to master curiosity on discovery, for the first time, of a leaf-cutter's abode, or on other the like occasion; but those from whom the maternal upholsterer is likely to meet with more consideration, may obtain, without invading her nursery, a very excellent notion of the style of its fitting up. This they may acquire from pages much more accurately descriptive than ours; $*$ but in the meantime we may briefly tell them how that, having excavated or found her hole (a cavity in ground, or wood, or wall, of from six to ten inches decp), she proceeds to construct within it, of the pieces of leaf she

* Réaumur; also 'Insect Arehitecturc.' 
cuts off, several cells, of the shape and about the size of a thimble, which she inserts successively, the bottom of one into the mouth of that below it. It takes from nine to twelve pieces of leaf to complete each single cell, and as each is finished, she stores it with a rose-coloured conserve made chiefly of pollen and honey collected from flowers of the thistle. When to this magazine of sweets is superadded the egg from whence its future consumer is to spring, the provident provider of the store covers in the whole with three more pieces of leaf cut in a circle as truly accurate as compasses could describe; room being left above this cover for insertion of a succeeding cell, our "upholsterer" thus proceeds till her nursery tunnel is completely fitted up.

Well might the gardener of Réaumur, on accidentally unearthing such a work of wonder as this nest of the leaf-cutter bee, suppose it, in his ignorance, the work of some magician!

As compared with the petals of the poppy, the leaves employed by the leaf-cutter (those sometimes of the mountain ash and birch, as well as rose), are materials of somewhat stubborn texture, herein enhancing the skill of their employer. It would seem, however, that pliability and thinness are qualities somewhat regarded and most wonderfully discerned by the little artist in question; for we have noticed, in more than one summer, the smooth, delicate, tender leaves of a dark variety of China rose, almost scalloped by the circles and ovals of her excision, while the foliage of the "cabbage," close by, has 
been left untouched, as if too coarse and common for her purpose.

The wool or down of pubescent plants, such as rose campion and cat's-ear, sharen off and "rolled up like a ribbon" for convenient transport, is used by another rather common species of solitary bee, to compose, not the lining or compartments, but the exterior covering of her nest, which is plastered within, and provided, like those before mentioned, with a store of suitable provision. Naturalists are somewhat at rariance as to this insect's mode of operation, it having proved a matter of difficulty to trace her to her nest.

Bee "carpenters" and bee "masons"-all working with maternal views, and named, like the "upholsterers," from the character of their labours-show no less ingenuity and perseverance in the employment of their more solid materials. The masons construct their nests, some with sand, some with earth and mingled chalk, some with earth and wood, uniting by gluten their grains or fragments.

The carpenters chisel their cells out of posts and palings a little softened by decay; and a nest of this description has been found, when cut open by a curious observer, ${ }^{*}$ to consist of a tunnel excavated in the wood, and divided by thin partitions of clay into five or six compartments, each with its supply of pollen for the single inhabitant who is to emerge from the egg deposited therein. $\dagger$

* Rennie, 'Insect Architecture.'

† See Vignette. 
Besides these, there are bee "miners," which, as their name imports, excavate galleries, for their nurseries, in the earth.

In all these varied operations, performed for a like purpose, the maternal bees, unlike the mothers of the feathered race, have to perform their tasks entirely unassisted by their idle consorts, who are never the partners of their toil.

These female artizans amongst solitary bees, have sisters in nearly all their crafts amongst the solitary wasps, many of which latter work no less expertly than the former in their different styles of maternally-designed architecture.* Nor are these waspish mothers a whit behindhand in providing for their nestlings' necessities, only showing their fiercer propensities in the nature of the food provided-which, in place of a heap of pollen, is usually a pile of flies or gnats, and sometimes, as in the case of the wasp " mason," a spiral column of living caterpillars, or a brace or two of live spiders.

On these, the number of which is nicely calculated to meet his wants, the young cannibal is nourished up to perfect wasphood, unless, spite of his mother's labours so cunningly protective, he himself fall a prey to the usurping offspring of some ichneumon-fly, who, more clever still, has contrived, cuckoo-like, to lay her egg within the nest he occupies.

One species of mason wasp, mentioned by Bonnet, approaches nearer than any of the above to the feathered race in her mode of supplying her young, for instead of enclosing at once within

$$
\text { * See Vignette. }
$$


her nursery larder a store sufficient to supply the future exigencies of its inmate, she, from time to time, carries thither a living caterpillar, opening and reclosing the nest for her entrance and exit.

The above are only a few instances, chosen from a multitude, which display extraordinary degrees of ingenuity, industry, and sagacity, exerted, prospectively, by insect mothers for the welfare of their progeny; but from the very circumstance of their care being of this prospective nature, and displayed, for the most part, towards as yet inanimate objects, we may not be disposed to view it, as with the larger animals, and birds, in the light of an implanted affection, but look upon it rather as a cold mechanical instinct, blindly followed for an end of which the agent can have no perception.

To a certain extent, this view may be no less applicable to the maternal offices of the feathered race and quadrupeds during the limited duration of their parental cares, tenderly and beautifully as these are exercised;-only, however, to this certain degree, because, under circumstances of unusual excitement, of danger or bereavement, the mothers of the brute creation are accustomed to display signs of feeling, solicitude, and suffering, quite distinct from, and over and above, that measure of instinctive care requisite for the rearing of their offspring, and very much akin, at least in appearance, to that surpassing love which warms the heart of a maternal parent of the human race. 
The hen, the cat, the lioness, and bear, also the whale, furnish familiar examples of such affection superadded to instinct; and parallel demonstrations of the like endowment are not wanting, though generally overlooked or disallowed, in some tribes of the insect world.

The prospective skill and care exhibited by solitary bees and wasps in the construction of their nurseries is probably, as with birds in the building of their nests, entirely of an instinctive character ; but we must assign, surely, one of a higher description to certain other features of insect maternity, with a few of which we shall conclude our imperfect sketch.

As in the instances of the quadrupeds above named, this love of offspring does not seem the most strongly developed in the mild and gentle of the insect tribes-such as are considered to represent the grazing animals, - but in those, especially, of fierce and predatory habits, as the cruel spider, the devouring water-scorpion, the already-noticed murderous wasp, and the, occasionally, cannibal earwig-the cats, sharks, bears, and tigers of the insect crew.

It might not so much excite our wonder to find the large feathery wings of the soft and beautiful butterfly, or those of the downy moth, spread, dove-like, over their eggs or infant broods, to hatch or cherish them. These, indeed, are not without their maternal instincts wonderfully displayed. The butterfly deserts her delicate repast among the flowers to deposit her eggs on the (to herself) uninviting cabbage, which is 
to support her progeny; and the moth, in one or more instances, * strips the down from her own body to defend her brood against the winter's cold; but if we want a parallel to the patience, the care, and affection of a brooding hen, we must look for it in the harsh, sharp, linear form of the earwig. De Geer tells us (his observations being confirmed by later naturalists) that she absolutely sits upon her eggs, as if to hatch them, and guards them with the greatest care; if scattered, collects them one by one into a heap, then resumes and assiduously maintains her sitting. When hatched, her nestlings, like those of a hen, creep under her, and are thus sometimes brooded for hours by the mother insect. $\dagger$

We have had an opportunity of observing for ourselves the brooding care of these insect Partlets, as exemplified in one which we transported from her nest beside a stone, and committed, with half a dozen of her white progeny, to the keeping of an inverted glass. Knowing that, in spite of an occasional penchant for a living subject, the usual food of earwigs consists of flowers, we put a blossom of dandelion into our pri. soner's coop of crystal-a piece of consideration for which we were amply repaid by seeing Mother Earwig commence, fortllwith, upon one of the yellow petals, which, directly afterwards, was attacked, at the bitten edge, by the tender jaws of one of her surrounding brood, thus led, apparently, to the repast which she seemed to have prepared for their more easy discussion.

* That of the Gipsy Moth; also the Gold-tail.

$\dagger$ See Vignette. 
The field-bug, also, we are told, conducts her large family of thirty or forty, as a hen her chickens. She never leaves them, and as soon as she begins to move, all the little ones closely follow, assembling, whenever she stops, in a cluster round her. De Geer, having cut off a branch of birch (a tree she inhabits) with one of these families, the mother showed every symptom of uneasiness : instead of inmediate flight she never stirred from her young, but kept beating her wings incessantly and rapidly, for the purpose, evidently, of protecting them from danger.

The egg-bearing water-scorpion displays even more attachment for her eggs than birds, for she never leaves them until hatched, carrying them always in a cluster on her back. The cochineal insects, of which one species affords the well-known dye, protect their eggs by covering them with their own lifeless bodies. Some of these little animals, with their eggs thus curiously guarded, and imbedded in a white cottony secretion, are to be found on grape-vines, too commonly for the gardener, especially near London. The hawthorn furnishes, in another coccus, another instance of frequent occurrence, in which the body of the mother insect, dried to a silvery grey skin, is to be seen protecting from winter's cold a multitude of her orange-coloured eggss.

The two habitudes last named, bear, certainly, most of the instinctive character, but at all events they are poetic in idea. Perhaps, however, none of the maternal traits above noted are 
so strongly marked as those wont to be exhibited by a species of spider common under clods of eartli, and often seen carrying her egggs in a white silken bag fastened to the end of her body. "No miser," says Kirby, " clings to his treasure with more solicitude than this spider to her bag. She carries it with her everywhere. If you deprive her of it, she makes the most strenuous efforts for its recovery. If you restore it, her actions demonstrate her joy. She seizes it, and with the utmost agility runs off with it to a place of security.

"When the proper time arrives, she makes an opening in the bag for the young to come forth, when they run in clusters on her back and legs ; she carries them about with her, and feeds them till able to help themselves." **

Bonnct's relation concerning an individual of the same species affords a striking parallel to those often recorded of cats, tigers, and bears, when robbed of their young. To put her affection to the test, he threw her into the pit of a large ant-lion, in the sand. The fierce creature seized her bag, when she struggled till its fastening gave way. She then regained it with her jaws, but by superior strength he pulled it into the sand, into which, rather than forsake her treasure, she suffered herself to be dragged also. Bonnet forced her from it, but, though repeatedly pulled away, she would not leave the spot. Many other species of the spider race have shown themselves scarcely inferior in maternal attachment.

* Introduction to Entomology. 
After instances like these, who can do otherwise than admit, with the amiable and enlightened Sharon Turner, that "in some insects the mother animal has those sensibilities of regard, care, anxiety, attention, watching, and protective guardianship, and that desire to feed and foster the young race which is to succeed the parental one, which the male has not been intended to possess and does not exhibit." The same author declares, that he considers "the mother as complete in the ant as in the whale."

Now with reference to ants, as well as social bees and social wasps, we must here notice, that though in them the maternal instincts and affections are developed, perhaps, even more powerfully than in any other insect tribes, it is with this remarkable difference, that, instead of being implanted chiefly in the parent herself, and that generally for a short period, they reign paramount, through life, in the working population of the ant-hill and the hive, with which, in fact, love of their young forms the very mainspring of activity.

But even here-as if this tender affection were always designed to be the distinctive characteristic of the female sexwe find that the "workers," on whom (though no mothers) devolve all the cares which usually belong to maternity, are none other than females, though of structure imperfectly developed.

We have particularly noticed in another place the curious practice of the mother ant in self-divesting herself (as a matron throwing off the gayer garb and habits of her maidenhood) of 
the ample wings adapted only to encumber her when about to enter on the duties of maternity-amongst others, the construction of nurseries within the earth. This labour she is accustomed to perform unassisted by the workers (who, in fact, are not in existence to assist), upon the foundation of a colony; but, as this becomes peopled, the duties of nursing the rising generation, feeding them, defending them, carrying them out for air and sun, \&c., \&c., devolve upon the latter.

The mother wasp also, as sole foundress of a colony, has also to labour hard for herself and infant family, till the latter affords a supply of workers to lighten or relieve her of her burdens. The queen of the hive is, for her part, much too great a personage to put her royal claw (or jazo) to any such menial occupations, her only business being to people her kingdom, indulge her appetites, and receive the devoted homage of her subjects. Amongst bees, therefore, the workers are the sole nurses of the infant community, which receive from their dignified mother no tokens of love or care,-which she would have, indeed, to divide amongst so many, that the smallest particle of attention could scarcely be bestowed on each. A family consisting of from seventy to a hundred thousand, all born within the compass of about two years, may be certainly allowed to exonerate their mother from any maternal office, save that of their introduction into the world; and, as contrary to what is usually the case with progenies of royal descent, that of the queen bee is destined to become 
the prop of the state, instead of only being supported by it, it is but just and proper that their infancy should be confided (Spartan-like) to the care of public nurses.

We see, therefore, that the royal mother of the hive, when she thus willingly relinquishes all property in her numerous progeny, fulfils as completely the duties of her exalted station, as head and parent of a nation, as the solitary poppy bee, the parent of humble private life, when, with prospective tenderness and care, she labours, herself, for the support and preservation of her single nurseling. Thus, with those varied developments of maternal instinct and affection exhibited in the insect world-as in all its ways, and works, performed under the directing guidance of Him who cannot err-all is harmonious, consistent, and adapted to its purposed end.

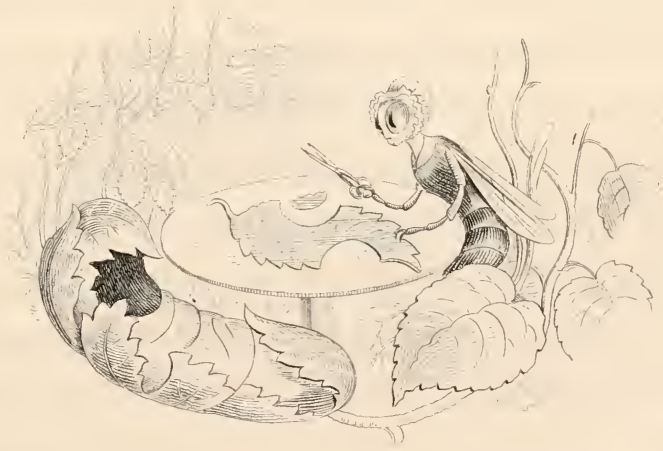

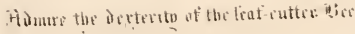




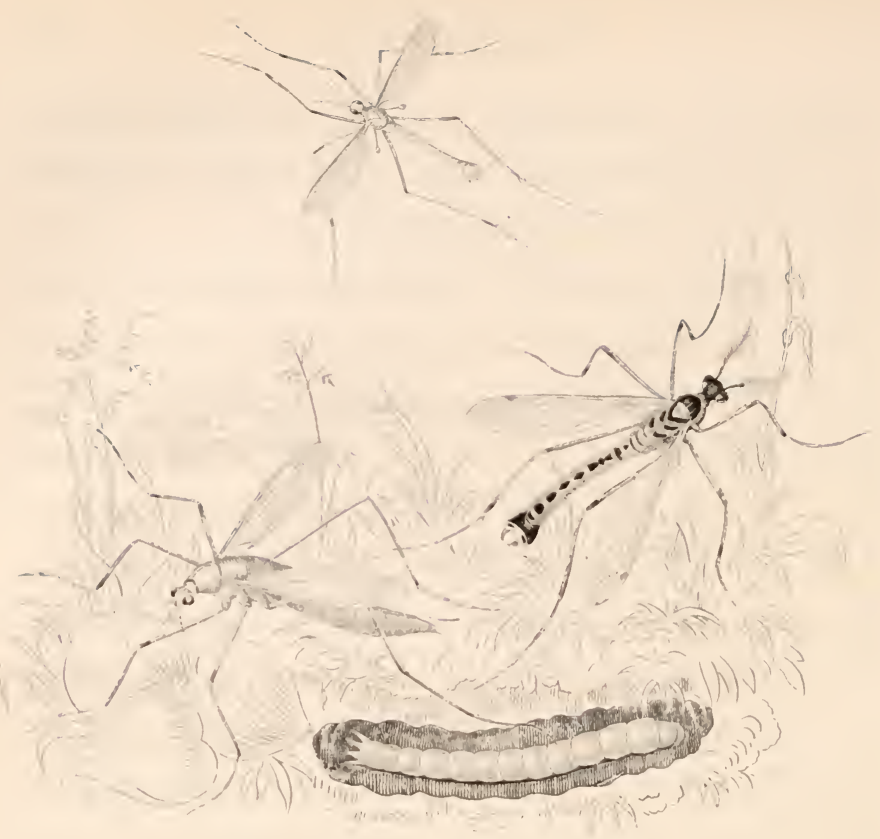

\title{
FATHER LONGLEGS AND HIS FAMILY.
}

\author{
" The so-called superfluities of nature \\ Are growths but fancied, sprung of Ignorance."
}

Next to the butterfly and the ladybird, we may perhaps assign a place, among the insect familiars of our childhood, to that ungainly skipper best known to us, wheresoever we may meet him-"upstairs or downstairs or in my lady's chamber"-as "Old Father Longlegs."

Our book-learning may have possibly made us acquainted with him, since, under the more refined epithet of Tipula, or a Crane-fly; but call the creature by what name we may- 
"Tipula," “Crane-fly,” “Jenny Spinner," “Tailor,” or "Daddy Longlegs," it was nothing but his legs which made him, in our childhood, an object of wondering notice; and it is at this prodigious length of shank that some grown-up people may be apt to wonder still; to wonder also for what purpose it was given; to wonder, thirdly, why the legs, which seem in truth hardly to belong to their owner, fall off so readily; and to wonder, lastly, at the unimpaired activity which he is accustomed to evince under the loss of one or more of his six unstable supporters.

Now, with reference to wonder the second and inquiry the first-that, namely, about the use, to its possessor, of an extra length of limb-no very probable solution is likely to present itself while we merely look at Father Longlegs when we happen to encounter him on stairs or in chambers, which, whether "my lady's" or "my lord's," are places where, in fact, he has no business-where he is nothing but an intruder-a stranger -and where, like other awkward creatures in strange society, he is never to be seen to the best advantage. But let those who would have a shrewd guess at the use of his ungainly members, take a peep at Mr. Longshanks when he is at home in his own element and in the indulgence of his own habits; for which purpose they can hardly do better than accompany us, this fine September evening, to some pleasant meadows watered by a running stream.

Here then we are, with the sun about to set in all his 
glory; and here is our long-legged acquaintance in his glory too, and full of glee amidst a crowd of his companions; now rising blithely on the wing-now footing it featly over the blades of grass, be they low or be they high, by the help of his convenient pins, used like stilts to over-top all impediments, and to prove to us, lookers-on, that stilts were given him for something, and for something better than idly to fan the dust of "my lady's chamber," as he waves them up and down in his rest of seeming restlessness upon wall or ceiling. As we look, now, on the movements of Father Longlegs, we seem to see clearly that long legs were given him because his proper business, exercise, and pleasure require him to make his way, not over level ground, but over high, uneven grass.*

Our stilted walker is now upon the wing, and, as he rises into air, we perceive another of the apparent uses of his lengthy legs. We notice now, that in the act of flying lis two fore legss are lorizontally pointed forwards, while the four hinder are stretched out in an opposite direction; the one forming the prow, the other the stern, of his trim-built vessel, in its voyage through the ocean of air.*

We see in this, his manner of aerial progress, an additional fitness of our Tipula's name of Crane-fly, and are forced to confess that the crane-fly has reason to glory in the length of his legs; but why he is so remarkably apt to lose them is a thing which remains rather less apparent to our comprehension. 
If we were disposed to seek moralities in the regions of fancy, we might suppose that this extreme fragility of the limbs of Father Longlegs was intended to keep him humble, reminding him of the slight tenure of bodily endowments, and thereby teaching him not to "ride too high a horse" over his more lowly creeping insect brethren; or, to suppose a purpose something nearer probability, we might suggest that since it is better to lose part than all-better to leave a leg behind than to part with life-that this very fragility of limb was given to the Father Longlegs by way of preservative, when he happens to be laid hold of by boy, bird, or spider. But not to pursue further such speculative notions, we shall close our observations on the crane-fly's shanks, by one other, founded on the indisputable fact, that with his singular aptitude to lose them is combined an apparent indifference about their loss, even more remarkable. This, with the like instances of seeming obtuseness to suffering from outward injuries, exemplifies a natural provision, of which (exposed as are insects to innumerable mutilations) it is not at all difficult to perceive the kind and merciful intent.

Spite of his long skipping strides and rapid flight, few insects fall, indeed, into more frequent jeopardy than the cranefly and his Tipulidan brethren, which, besides a host of more open enemies, are not without their fox-like destroyers. Taking now the circuit of our meadow, we find the hedges beset thickly with the nets of geometric spiders, each with its 
cunning artificer suspended, head downwards, in the centre, or else beside it, half hidden by a leaf, so as to watch, unseen, its eagerly desired victims. And see! a single crane-fly, a deserter from the stilted phalanx on the grass, rises, sweeping towards the hedge, and (silly or short-sighted little animal!) unconscious of the warning tokens-heads, wings, legs, of murdered or mutilated comrades which bedeck the net of the spider-touches the circles of the fatal maze. It trembles to its centre, and from her leafy ambush out rushes the grim destroyer.

Hapless Father Longlegs! not by the leg art thou this time entangled, for then, with a leg minus, thou mightest have proceeded on thy flight; but by the wing thou art fast holden, and, struggle as thou mayest, before thy regardless fellows have finished their sunset gambols, thou wilt be reduced to nothing but a headless, wingless, legless trunk, occupying, in the grasp of thy sleek, fat-bodied murderess, the centre of her terrible snare.

So here is an end of Father Longlegs; but he lives always in others of his race, about whom there is still something to be observed worth noting, albeit not quite so noticeable as their giraffean supporters.

If any of our friends will take the trouble to look narrowly at the next Longlegs, rested conveniently for inspection on wall or window, they will perceive (what perhaps they never saw before) two curious little appendages, like drumsticks, placed 
behind each wing; for what purpose it may puzzle them to tell. These instruments, which are by no means peculiar to the Tipula, but possessed also by the common house and other two-winged flies, are called poisers, and, as their name imports, are considered to balance the body and render the flight more steady, serving (as says Derham*) "to the insect, as the long pole laden at the ends with lead does to the rope-dancer." The same naturalist tells us, that "if one of these be cut off the insect flies one side over the other and falleth ;" and another, who supposes them air-holders, found that a Tipula deprived of both could not fly at all.

Of these same appendages it has also been suggested, that, by their employment as veritable drumsticks beating on the wings, they may assist in the production of that buzzing sound, to account for which has puzzled not a few philosophers. But however this may be with the two-winged band in general, the little knobbed articles, to which we are now directing special notice, are not thus employed, seeing that it cannot be said of the crane-fly, as of some other fliers, and of that celebrated lady "with rings on her fingers and bells on her toes," that "the 'longlegs' makes music wherever he goes."

Those who behold the crane-fly only in its proper personin the elevated maturity of its stilted supporters-must not suppose it has been always thus exalted above its fellows, nor must they imagine it to have grown by degrees to its present 
stature. Be it remembered, that perfect insects never grow ; and to commence from the beginning the life of a Father Longlegs, we must go back upon a period when he had not a leg to boast of; when he and his skipping comrades, now giving double life, by their gymnastics, to the grass they sport in, were all buried underneath it in the form of legless, wingless grubs, * doing their best, by gnawing at its roots, to deprive this very grass of its own quiet measure of vegetable vitality. In fact, these harmless-looking idlers are accustomed, in their state of infancy, to play very serious pranks, though neither by daylight nor by moonlight, under cover of the suffering herbage. Exactly in reverse of the fertilizing influence of fairy footsteps, they turn the green sward brown by invisible workings, quite as withering as were once esteemed the fabled mischiefs of the brownies themselves; and it is not unlikely that to those, or other the like imaginary agents, was often ascribed, in days of yore, the occasional cutting off of hay-crop promises by the trenchant jaws of crane-fly devourers in their grubhood.

But the longlegs himself is harmless? Why, no ; inasmuch as he, and his long-legged mate, are the parents of these verdure-blighting imps.

If we look at the slender bodies of different Tipula of the same species, we shall perceive that some of them are truncated, or as if cut off at the end, while others are finished by a sharp, 
awl-like point.* Now this pointed instrument, which always belongs to and betokens a hen among these insect cranes, she employs, under direction of prospective instinct, to bore the ground for deposition within its bosom of her numerous eggs. From these, which have been compared to grains of gunpowder, issue in due season the verdure-blasting trains, which, devouring the roots below, give to the herbage above the appearance of being scorched by fire, or even totally consumed; as in an instance, adduced by Mr. Rennie, of an acre of ground at Blackheath, which he saw in the summer of 1828, " stripped of grass and everything green, as if pared off from the surface" by the full-fed larvæ, then about to assume their second form of pupæ. $\dagger$

Réaumur, who describes resembling effects from the like insect causes, in Poitou, opined that these destructive little animals are earth-eaters, causing injury to roots only by disturbance of the ground. This supposition is admitted by the naturalist before named to have some confirmation in the fact that certain species of Tipula feed, as grubs, upon the vegetable mould in hollow trees; but, amidst different opinions, it would seem still a questionable point, whether the lanky limbs of Father Longlegs are to be considered as most of earthy or of rooty derivation.

But upon whatsoever nourished through its first estate, the Tipula, when it ceases to be a grub, leaves off grubbing after

* See Vignette.

† 'Insect Transformations,' p. 254. 
earthy roots or rooty earth, in the midst of which it how ever quietly remains; while under the encasing form of $p u p a, *$ the long legs, with all accompanying members of the "coming" fly, are brought by degrees to their full measure and perfection. Before, however, this important epoch quite arrives, our Father Longlegs, now a long fellow in a sack, seeming through a load of superincumbent earth to smell the air, contrives, cleverly, to work himself upwards, not merely to the surface of the ground, but to an inch or two above it of upright elevation. Thus supported by surrounding blades and stalks of grass, comes forth, at length, in all his disproportioned, yet appropriate lengthiness of limb, the Tipula, alias Crane-fly, alias Tailor, alias Jenny Spinner, alias Father Longlegs, whose long history we thus end just where we began it.

Pupa-cases, such as above described, either occupied or vacant, may sometimes be seen in scores amongst the herbage where crane-flies are abundant. The practice of these, in wriggling themselves towards or above the surface, whether of ground or tree, wherein they have been imbedded, is one frequently exemplified in the pupæ, or chrysalides, of various insects, whose delicate wings would otherwise be injured in the bursting from their temporary tombs. One amongst thousands, this, of those nice provisions of Providential care, such as cannot but excite our love and admiration.

Besides the common Tipula, there are others of nearly 
resembling size and figure, but much more gaily coloured. One of these* sports, instead of the sober russet-grey of Father Longlegs, an extremely handsome uniform of black and orange-yellow, black-tipped wings, and plumed antennæ of imposing length and beauty. This, with others of the more distinguished few of the Longleg family, is only likely to be met with singly, sporting beside woods and hedgerows, never in troops over grassy meadows; and even their grubs, with birth-places less lowly than the common herd, generally first see the darkness, not in subterranean vaults underground, but in the hollow chambers of decaying trees.

There is a certain little fly, with a bright orange-coloured body, rounded and fringed wings, and feathered antennæ, belonging to the Longleg family, but compared with which the "Father" of it is a perfect giant. As with his Robin Hood relative, the rapacions propensities of this Little John are all exercised in early life-the period, namely, of his grubhoodwhen he "sows his wild oats" by committing excesses on our cultivated crops of wheat. While these are yet in bloom he revels on the pollen of the florets, and leaves, in the deficient or withered grain, serious tokens of his destructive presence.

So extensive, in a multiplied form, are the injurious operations of this tiny midge, that he and his companions in mischief have acquired general notoriety, under the name of " the Wheat-fly." $\dagger$

* Ctenophora ornata.

† Cecidomyia Tritici, Kirby.

VOL. III. 
Besides the above, there is a mixed multitude of small Tipula, or long-legged flies, much resembling, and often confounded with, the gnat; though the common gnat is sufficiently distinguished by the singular transformations of its aquatic larva, described already in 'A Life of Buoyancy.' In their last and perfect stage, many, however, of these Tipulidan flies, or gnats, are full as buoyant as those to which the latter appellation more properly belongs: like them, they are often alert and joyous, while other insects are dead or dormant; like them, fly unwetted in the shower, and often, like them, dancing in the winter shade, hold, in defiance of the gloomiest season, their "mid-day sports and revelry."

But it is not with such diminutives that we should conclude handsomely our notice of the line of Longlegs. Let us return instead to the stilted "fathers" or mothers of the tribe, with a random guess at the derivation of one of their incongruous appellations. Why they should be called "Tailors" we cannot tell, unless, as animals made up of legs, they may be considered but as fractions-ninth parts, perhaps, of an insect. Why creatures never known to spin a thread should sometimes also be named "Jenny Spinners," was, to us, no less a mystery, till, on a summer's day, its possible solution flashed upon us. We were sitting in a shady lane, when, on the turf that bordered it, what should appear but a single Mother Longlegs-neither flying nor walking, but whirling and spinning round in a strange eccentric manner; her wings 
and fore legs beating the air, her hind ones bent at their angles so as to let the end of her pointed body, which was held bolt upright, come in contact with the ground. Here, then, was our "Jenny Spinner," not thus spinning for amusementmerely to make herself, like a votary of the waltz, drunken with delight,-but gravely spinning mischief to the grass. With the united points of her sharp shining forceps she was gimletting the turf, and in every hole dropping one or more, perhaps, of her grain-like eggs, germs minute of future longlegged spinners, which, to an atom multitude of surrounding creepers, were to be as ostriches to wrens-as camelopards to field-mice !

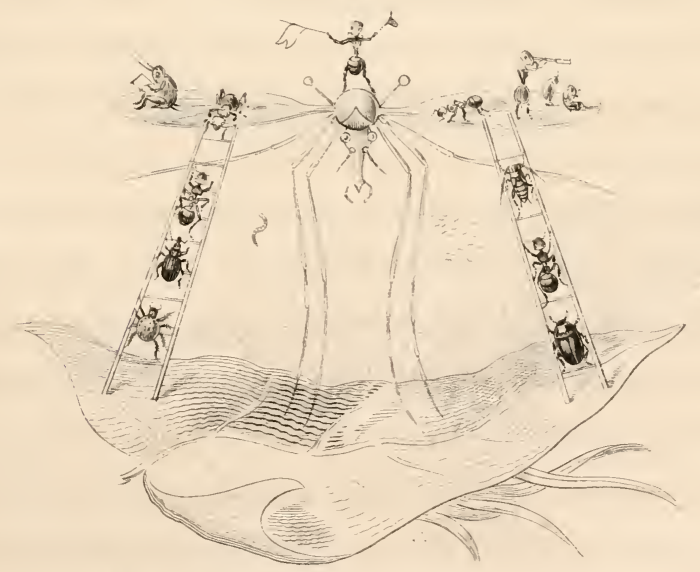

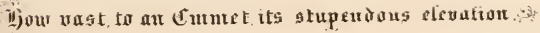




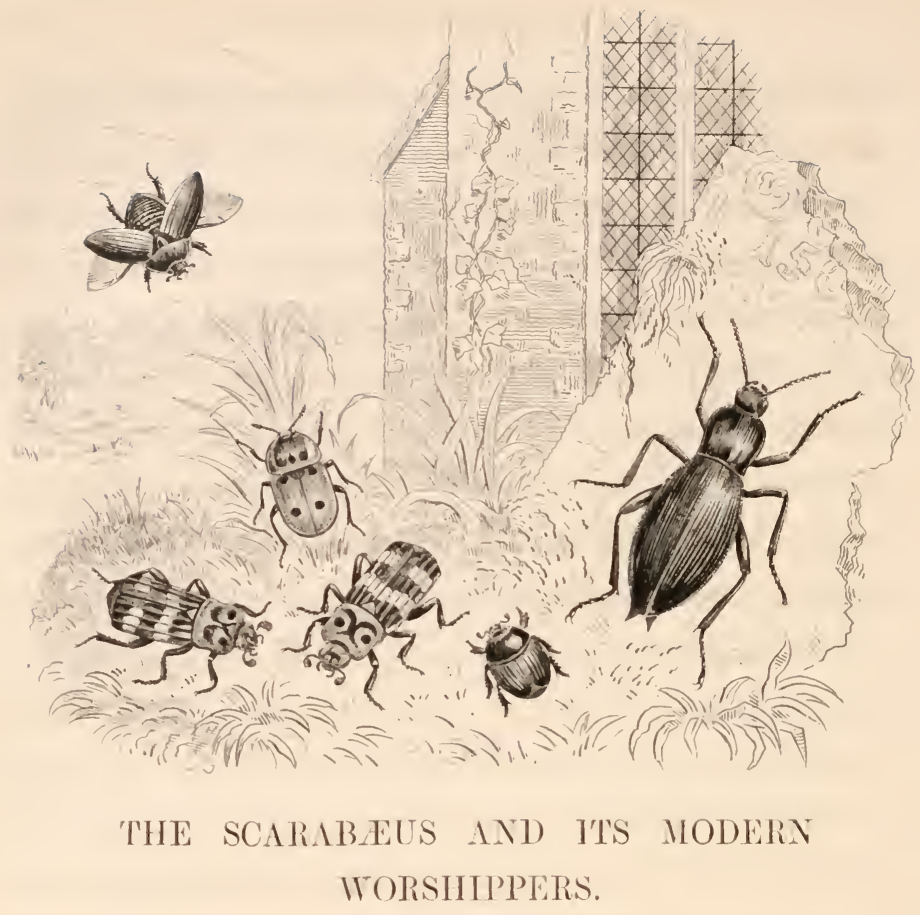

"Like to those balls which sordid Bectles roll, Infusing into them their dunghill soul."

Wiat a striking contrast is there between the two insects which figure most conspicuously in the annals of antiquitythe butterfly and the dung-beetle! The former was regarded by the ancients as an emblem of the soul, the latter was made by them an object of the soul's worship. The one, all beauty, vivacity, and buoyancy; having no business in life but pleasure-no habitation but among the beautiful flowers, 
and breathing the perfumed air of summer. The other, in form dark and repulsive, in habits dull and laborious; its abode beneath the earth, or within the loathsome substances which cumber earth's surface, and its favourite atmosphere one of steaming fetidity thence exhaled.

Yet this, the Scarabcus sacer, or Sacred Beetle, was the creature which the wise and civilized Egyptians imaged on their sepulchral monuments, enclosed with their embalmed bodies, carved on their lofty columns, inscribed on their astronomical tables, looked on as symbolic of the world, and of the glorious sun,-nay, adored as a visible deity!

What lamentable darkness! we are ready to exclaim, looking back with contemptuous pity on the beclouded ignorance from whence we have emerged; even though the learned tell us that under the above and other seemingly the most absurd of Egyptian superstitions, was veiled a hidden wisdom. The priest-ridden, hood-winked "million" saw, however, it is probable, nothing more in their Apis, their Ibis, and their Scarabæus, than a beast, bird, or insect god, so regarded on account of some beneficial or formidable quality, exciting gratitude or terror; the priests themselves only viewing them in a more refined sense as symbols of the Deity, in one or other of His divine attributes. In the Scarabæus the male insect closely resembles the female, and, contrary to insect usage, is accus. tomed to participate in her labours. On these accounts it has been supposed that the Egyptians, not distinguishing between 
the individuals of each sex, imagined that the Scarabæus was of both combined, and, under this mistaken notion, adopted it as an appropriate emblem of a self-created and supreme First Cause ; and whenever, therefore, they desired, in their hieroglyphic writing, to designate a being self-produced, or to express an idea of a birth, a father, or the world, they represented a Scarabæus.

This insect was also more especially the symbol of their goddess Neith, whose attribute was supreme power in governing the works of creation, and whose glory was considered to be increased rather than diminished by the presence of another porrer named Phta, the Creator. Neith and Phta, thus considered as two attributes of one spirit (the third being Cneph, or Divine Goodness), are, in their combination, further represented by the supposed union of both sexes in the Scarabæus. As typical of Neith, the insect was carved or painted on rings, and worn by soldiers, in token of homage to that Power which disposeth the fate of battles. It was also thus worn, and otherwise employed to designate a warrior, from the manly bearing connected with its supposed paternal birth; and, sculptured on astronomical tables, or on columns, it expressed the Divine wisdom which regulates the universe and enlightens man. Other symbolic meanings were attached to the Scarabæus, founded on certain peculiarities in its habits and external form.

The modern representative of the Scarabaus sacer (imported from Africa into southern Europe) is the Pill-Beetle, so named from its practice of moulding round pellets of dung, depositing 
an egg in each, and then, by the assistance of the lind legs and extremity of the body, rolling them backwards into a deep hole, previously excavated for their reception. If one of the insects finds itself inadequate, alone, to the performance of this task, it is accustomed to call in and obtain the assistance of one or more of its fellows. This, certainly, is a habit sufficiently remarkable to attract attention from the least observant, and, as one of Nature's uncommon wonders, it formed, in times of superstition, a convenient peg whereon to hang a tissue of embroidered fiction. The Egyptians, accordingly, were wont to regard these insect labours as symbolizing those of Osiris and the Sun; the balls of dung were exalted into types of the world, and, the beetles being supposed to push them always from east to west, for twenty-eight successive days, their movement was made also to represent that of the habitable globe. To carry out this symbolic scheme, the Scarabæus (reckoning five joints to each of its six feet) was said to have thirty fingers, corresponding with the number of days in each sign of the zodiac; while, to complete the analogy, the six notches or angular projections of the insect's head were likened to the rays of the sun.*

Add to all these imputed characteristics, that of youth, annually renovated, and we have the Scarabæus of antiquity; a creature which, however wortlless in its fancied attributes, was

* Latreille, 'Annales du Muséum,' 1819. 'Des Insectes peintes ou sculptés sur les Monumens de l'Egyptc.' 
highly valuable in its real usefulness as an insect scavenger, and in this capacity was to the full as worthy of being held sacred as the snake-devouring ibis, the egg-eating ichneumon, or the man-eating crocodile.

The Scarabæus was never, that we know of, made in England a recipient exactly of divine honours; yet would it appear that this, or a beetle of similar habits, held no mean place in the estimation of one at least among our ancestors, and in times comparatively recent. Mouffet, one of the fathers of entomology, is loud in praise of its virtues, which (according to him) should serve as a stimulant to every good quality, -should invite to labour, temperance, prudence, justice, modesty, and should teach man contentment, by showing lim how a beetle can luxuriate in a bed of dung, just as well as in a bed of roses. How justice should have a place in this catalogue of virtues to be learnt from beetle practice, puzzles us, we confess, to discover; nor may it be worth the trouble of inquiry. Perhaps it would better suit our purpose to see whether this once worshipped and lauded Scarabæus has sunk, in these modern times, into utter disregard; or whether amongst those who, perhaps, know him not by name, there may not be found a considerable number who, inasmuch as they follow his ways, may be said still to worship his image.

Where, at all events, shall we find a better emblem, if not a better god, for the busy of the money-making, money-loving world, living immersed in filthy lucre, than the dung-abiding 
beetle? Like it, are they not for ever toiling, from rise to set of sun, to amass and roll together their corrupt riches? And for what purpose? Not to diffuse, but to bury them, even as the beetle, in the earth of their sordid selfishness. Sometimes, like them, they may amass also for the benefit of offspring-offspring, perhaps, with inherited instincts for sordid accumulation - chips of the old block, who, when they come after, continue to roll on, in the same useless heaps, the same filthy lucre, which in wide and generous distribution would become as manure to fertilize the soil.

Verily, shade of Sir Thomas Gresham, thou princely merchant! save but for respect for thee, and for the remnant of noble traders which, with the baser sort, are now wont to assemble in the modern halls surmounted by thy ancient grasshopper, we would even tear down that classic, youthful, rural, mirth-loving insect, and set up, in its stead, a gigantic Scarabæus, which, stripped of its fabulous, but clothed in all its veracious attributes, would be, of all symbols, most appropriate to surmount a temple of Mammon.

But if we spare the grasshopper, we would venture to suggest, for the edifice in question, another Scarabæan finish, which, however little ornamental, might be of infinite use. On some conspicuous station, grinning grimly at the grasshopper (the Athenian emblem of perpetual youth), we would elevate a great black effigy, not of the Scarabaus sacer, but of the "churchyard beetle," in the form of a huge vane, so that, whenever 
an anxious merchant, whose "mind is tossing on the ocean," shall look eagerly upward to "know where sits the wind," he may be reminded, by an emblem of mortality, that the ship Death, for which, perhaps, he is booked an early passenger, may be coming from the north or south, or east or west, and that sooner than any one of his expected argosies.

The sacred beetle of Egypt is not a native of Britain, and only of Europe as naturalized in its southern countries from the neighbouring continent of Africa. It is only, therefore, in insect collections that the Scarabæus proper can be seen in its own desiccated person. Figures thereof, both sculptured and painted, are, however, always on view with the Egyptian antiquities in the British Museum,-some smaller than their original, others of gigantic size,-but they are said to be, in general, pretty correct representations of the thing intended.

But though we have not a Scarabceus sacer in the list of our indigenous beetles, we have an insect greatly resembling it in form, as well as habits, which may be met with almost everywhere, and on every day from Nareh to October. This is no other than the "great dor," or "clock"-the "shardeborne beetle" of our immortal Bard,- - that which, on summer and autumn evenings, so often with drowsy lium wheels lumbering past us, or bangs up right against us.

Like the Scarabrus, this clock-beetle* is, in figure, broad, and short, and clumsy. His forehead has none, indeed, of those

* See Vignette: Clock Beetle, Geotrupes stercorarius. 
sun-like rays,-in plainer language, none of those vandyked notches which distinguish that of the Egyptian, but it is adorned, like the latter, with a pair of horns,* finished by laminated or leafy tips. Black, in both insects, is the prevailing hue, at least on the upper side; but in our cor, the wing-cases are tinted on their margins with bright violet, while the legs and whole of the under surface are cased in armour of steely blue, glossed with green and purple. The exterior, indeed, of this dweller in defilement is far from unpleasing, and he is remarkable, as well as others of his tribe, for absence of all unsightly traces of his habits or resorts.

To look at the unsullied polish of his mail, one might suppose him risen, like the green gold-chafer, from a bed of roses; whereas, being a true Scarabæus in nature, if not in name, there is little doubt, when we see him in his evening flight, of his having left recently a bed of very opposite description-a bed, in short, of dung-wherein, through the live-long day, he has been reposing; or whereat, like his Egyptian prototype, he has been hard at work, helping, perhaps, his partner to roll masses for enclosure of her eggs, or to bore holes for their reception.

The drone of the dor-beetle was once taken as a prognostic of fine weather, and is esteemed by some people, although a harsh, yet by no means an "undelightful hum." 'To us, associate though it be with warm and guiet evenings, there is 
always a sort of sadness in its sound, perhaps because it reminds us of Gray's 'Elegy,' perhaps because, being most often heard towards autumn, it comes like a requicm of departing summer.

Allied to the above, as belonging to the useful company of inscet scavengers, are the "Burying Beetles,"* so called from their being accustomed to perform the office of grave-diggers to defunct frogs, birds, moles, "mice, and such small gear," whose bodies would else cumber the ground more extensively. A common species of this serviceable family of the Coleopterous order is a pretty-looking insect, considerably smaller than the "great dor," and easily distinguishable from that and other black beetles by two broad scalloped bands of decp orange-colour painted across its black wing-cases, which are a good deal shorter than the body, and have the appearance of being truncated, or abruptly cut across the ends. The thorax, head, and legs are of a deep black, also the body; the latter fringed at the sides and articulations with yellowish hairs; the antennæ knobbed and foliate at the tips.

We must inquire now into the " burying beetle's" motive of incitement to its laborious occupation of interment. It is not certainly the promotion of our sanitary benefit that the creature has in view; neither, we suppose, has respect for the dead or their families much to do with its burial of animal remains. The incentive to the work is not to be found in mere 
love of labour, nor yet in love of self, but is, in fact, like the mainspring of various other insect actions, of a parental character. Its eggs being first committed to the carcase, the beetle then proceeds to commit that to the earth, in order that, thus protected from predatory birds and foxes, it may afford provision for her young, as soon as, in the shape of larvæ, they come into existence. This most curious practice of instinctive sagacity was first noticed by a foreign naturalist, M. Gleditsch, who, having observed the mysterious disappearance of moles, laid upon the beds in his garden, discovered that beetles were the agents of their inhumation, effected for the purpose above named. To watch their proceedings more narrowly, he put four of these insect grave-diggers into a glass vessel, half filled with earth, on the surface of which were laid two dead frogs. Of these, one was interred in less than twelve hoursthe other on the third day. He then introduced a dead linnet, on which the beetles were speedily engaged. They began their operations by pushing out the earth from under the body, so as to form a cavity for its reception: and it was curious to see the efforts which they made, by dragging from below at the feathers of the bird, to pull it into its grave. The male, having driven the female away, continued to work alone for five hours. He lifted up the bird, changed its place, turned and arranged it in its grave, from time to time coming out of the hole, mounting on the carcase, treading it underfoot, and then again retiring below to draw it to a greater depth. At 
length, wearied apparently with this incessant labour, he came forth and laid his head upon the earth beside the bird, without the smallest motion, for a full hour, as if to rest; then again crept under the earth. The next day, in the morning, the bird was an inch and a half below the surface of the ground, and the trench remaining open; the corpse seemed as if laid out upon a bier, surrounded by a rampart of mould. In the evening it had sunk half an inch lower, and in another day the work was completed, and the bird covered. Other dead animals being added, the four beetles, in fifty days, interred no less than twelve bodies in the narrow cemetery allotted for their work.*

Of a sepulchral character in unison with the above, but of associations much more gloomy as connected with ourselves, is the bectle of the churchyard, $\dagger$ our proposed pattern for a vane on the Exchange.

This dark, ill-favoured, ill-scented, and, in the eye of superstition, ill-omened insect-whose proper name (Blaps mortisaga) savours of mortality as strongly as its common, though not popular appellation-is one of those creeping things from which whenever, in its favourite haunt, it happens to cross our patl, we turn instinctively away, even as we are wont with other, the like mementos, come they in what shape they may. "To smell to a turf of fresh earth," says an old writer, "is

* M. Gleditsch, quoted by Kirby and Spence; also in 'Iusect Architecture.'

$\dagger$ Blaps mortisaga. See Vignette. 
wholesome for the body; no less are thoughts of mortality cordial to the soul." Cold cordials they are-bitter and distasteful; but for this none the less salutary; and plenty of us life-lovers, besides the sordid worshippers of the Scarabæus, require their assistance for our moral health. The ancient Egyptians, through their mingled haze of light and darkness, were able to discern the wholesomeness of not forgetting they were mortal, and, to prevent it, were in the habit of introducing an image of Death in the midst of their festal scenes. This was well enough, as might be the churchyard beetle on a temple of Mammon. The mind, however, soon grows blind to what the eye is accustomed to behold; and we doubt if the individual who kept his coffin under his bed, thought, after awhile, at all more frequently than the rest of us how soon he might become an occupant of the narrow house. As with the employments of the undertaker and the grave-digger, "custom" would bestow on all these intended prickers to reflection "a property of easiness." For this reason, the most awakening, perhaps, of all such remembrancers, are those which, like the churchyard beetle, in its living form, come upon us unawares, crossing suddenly our sunny summer pathways.

The sepulchral locality in which the Blaps mortisaga is usually met with, may serve, of itself, to enable those unacquainted with insects to give a pretty shrewd guess as to its character and occupation. It may also be distinguished as one of the blackest of all black beetles, its funereal sable being 
totally unrelieved by those tints of green, and blue, and violet, or even brown, which, in most others of its tribe, serve to enliven their prevailing sombre hue. In form, this haunter of cemeteries is rather long and slender, both the body and the wing-cases, by which it is quite covered, terminating in a tapered point. The antennæ are jointed in their whole length, but are destitute at their extremities of foliated knobs.

The churchyard beetle is an inhabitant of cellars as well as cemeteries, also of underground kitchens and other dark damp places. With all its associations of mortality, this insect is remarkable for length and tenacity of life. One was found to survive three years of "total abstinence" from food; another, a whole night's intoxication - at least, immersion in vinous spirits. Connecting this strange vitality (paralleled only in the insect world) with its gloomy resorts and goule-like habits, one can hardly wonder that the beetle of the churchyard should have been held by the observant ignorant as an object of dread as well as detestation.

Amongst beetle families of Scarabæan habits, are several foreigners of gigantic size, and of forms remarkable for various horn-like excrescences; and some of the like peculiarities on a smaller scale are observable in a few of our own dung-frequenting Coleoptera. Of these, one ${ }^{*}$ exhibits a recurved horn projecting from the centre of its shield; while the forehead of another is adorned with a pair of cornuted appendages 
resembling exactly those of a bull, from whence its name of Onthophagus Taurus.

This and others of its family, as chiefly vernal insects, have been designated as "agreeable," despite of their unpleasing habits.

There is another set of little leaping beetles, called IIisterida - also spring visitants - whose exterior is really much more prepossessing than their resorts and practices would lead one to expect. Some of these present us with exceeding pretty specimens of nature's sculpture; and, from their habit of contracting the legs and antennæ immediately upon being alarmed or touched, resemble, when thus indrawn, a carved seed (usually black, or black and red) rather than a carved insect. Hence derived are their familiar names of "Pill" and "Horse-bean beetles."*

Of these, some are workers in the same unsavoury substances as the dor or clock; but a peculiar office usually allotted to this tribe is to commence the destruction of dead carcases by piercing through their skins, on which the Hister is a feeder, thus making a way for its fellow-labourers in the work of clearance.

Flies are usually the next agents of consumption, followed by a host of other beetles, of which the rearward force is composed of such as exhibit a peculiar penchant for dry bones.

Amongst the latter are those called Dermestida, accustomed, 
like the Histerida, to draw in their legs and simulate death on being touched : while, acting as their assistants in discussion of bones and other desiccated remains, there come (in the form of larva) certain other consumers. These, when they arrive at their maturity as pretty little coloured beetles* (some black and grey and red), accustomed to frequent flowers and fragrant places, we should hardly suspect of the unpleasing but useful habitudes of their earlier days. These also put on death's semblance to escape death or danger.

Let us take now a general and conclusive view of the grand company of beetle scavengers, as instrumental to the benefit of mankind. We must have seen already the importance of their operations, even as we have slightly sketched only a few of them, and as performed only on the narrow theatre of our native soil, and must have noticed also the wondrous order observable in their sanitary works. But it is requisite to look farther-to cast an eye orer the whole habitable globe-before we can perceive, in anything like its true extent, the magnitude and method of insect agency, - that, especially, of beetles, as assistant to carrion-birds in the business of removing offensive objects. In this survey, there becomes apparent one beneficent provision of Nature (more properly of Nature's God), which cannot but excite our admiration,- that, namely, of the geographical distribution of insect scavengers, as observed always to be in exact accordance with the need for

* Of the genus Anthrenus. 
their services. In temperate climates, where decomposition from atmospheric causes moves at so slow a rate as to require adventitious aid, their number is large; in hot and arid atmospheres, as in the Pampas of South America, where a carcase becomes dry almost before putrefaction, and where travellers can make a fire of a dead horse, they are comparatively rare.

Contemplated thus under their aspect of usefulness, much of our very natural repugnance to the gloomy habitudes or unclean propensities of the beetle Scarabæus and its indefatigable fellows, must give way to thankfulness that such creatures exist; also to admiration of that nice endowment of adapted sensations, faculties, and powers, which direct and enable them to do, in our behalf, the bidding of their Creator.

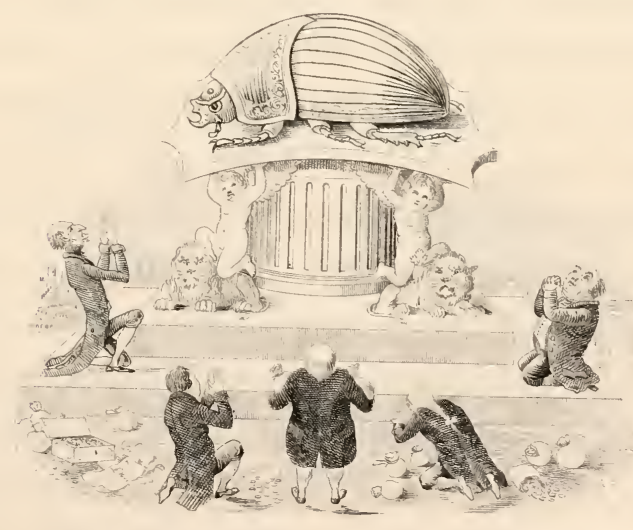

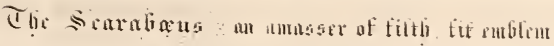
at Itl umuran-usorstip. 


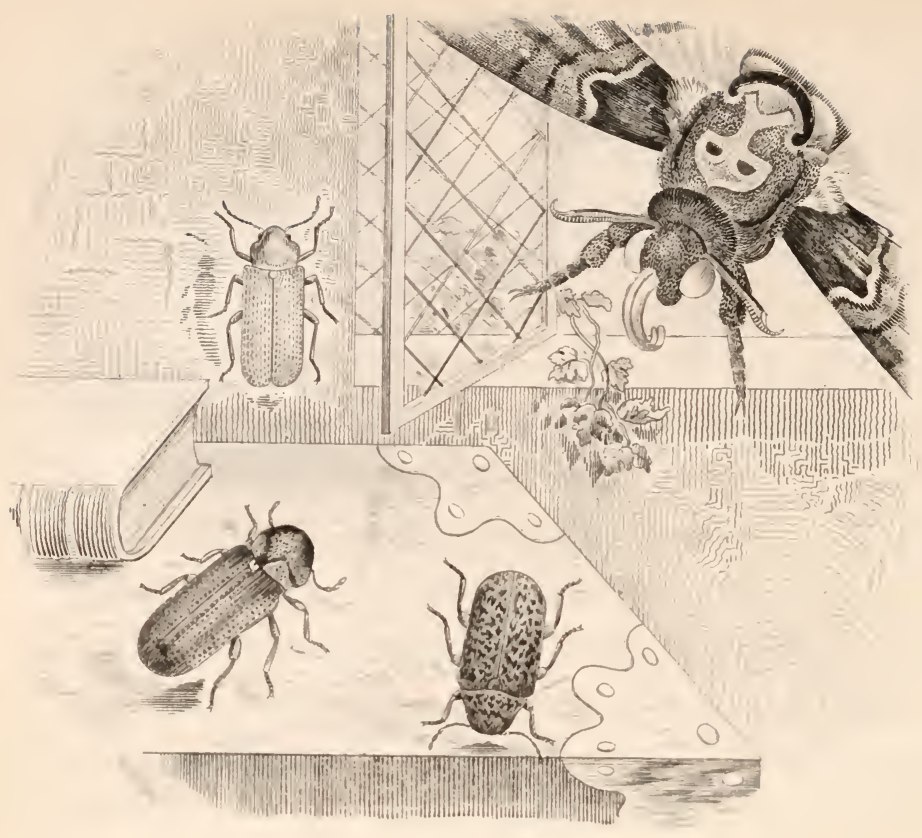

\section{INSECT DIRGE-PLAYERS.}

"Dreamed I, around us viewless spirits dwell,

To tume our minds and consccrate our thoughts."

Ix the joyous spring-time we devoted a few words to insect Minstrelsy (that of the joyous kind), with its associate sounds, real or fancied; and, as set in motion by their spirit-stirring influence, we imagined "a dance of life" made up of associate images mingling in a merry maze before the mental eye. But where are the cheerful things of earth without their gloomy counterparts? where the budding springs without their fading autumns? and in this, the autumnal season, let us see if there 
is not to be found a choir of insect musicians whose dirge-like strains are well suited to the departing year; each with an appropriate accompaniment of gloomy or boding sounds, audible, perhaps, only to the mental ear, yet with power sufficient to get up a dance, not of life, but of death,- to set in motion a train of shadowy phantoms, which take hands, and foot it, not "featly," but with due solemnity.

It must be owned, however, that such mortuary music, of which the key-note may be struck even by an insect or a bird, is getting out of date, having had its day-more properly its night-with all but very children, infant or adult. Superstition, after scaring good and bad, high and low, for centuries, has, in these modern days, been scared herself by the advancing daylight of science. From baronial hall, and turret chamber, and gloomy corridor, and winding stair, she has descended to the cottage, or been kicked down to kitchen and kitchen company; and even here begins to totter, sore buffeted by missiles from the penny press. Showing symptoms of age as well as degradation, the hearing and sight of her antiquated ladyship have grown dull, ceasing, as of yore, to magnify the volume and the import of boding sounds, with their awful phantasmagoria of shadowy shapes. But before both Superstition, and the performances of which she was once the frequent getter-up, quite sink for ever from their last and lowest stages into the pit of oblivion, let us just take a passing look at the giant terrors which even insect dirge- 
players have had, and in some cases may still have, the power to create.

$\Lambda$ t the open window of her solitary kitchen, half lighted by this Oetober moon, half by a flaring candle, sits All-work Deborah at her tea. Why, suddenly arrested in its prophetic orbit, does the tea-cup, in the very turn of fortune, drop, shivered, from her shaking hand? Why does her tallowy dip, dip at once into darkness? What is the wailing cry that salutes her startled car? Is it the voice of a screech-owl from the barn, or the squeal of a mouse from the cupboard? No! It is the shrick of some gloomy night-flicr, which, entering at the casement, has put out the candle, and deposits its dusky form upon the snow-white dresser. Deborah can only dimly discern it by help of the moon. "Oh, for a light! My swcetheart for a light!" she inwardly ejaculates; but the evening is warm, the grate is cold, and the damsel dares not stir.

$\Lambda$ length, however, in some way or another-whether by aid of embers or of lucifer, not Deborah herself could ever tellthe candle is relit; she could only testify that its flame burnt blue. With trembling hand she places it on the dresser, to "show up" the characters of her alarming visitant, who ever and anon continues to salute her with its mournful wail.

Deborah is a country girl, and has therefore learnt, of course, to distinguish betwixt a butterfly and a black beetle; and she thought, till this awful moment, that she knew, quite as well, the difference between a brown moth and a spirit, black, 
white, or grey. That the thing upon her dresser is a moth, of size prodigious, the candle seems to tell her; but there, as it lies, vibrating its dingy pinions in unison with its dismal cry, somewhat else seems to tell her that it is no moth at all, or a moth of most strange unnatural behaviour, not at all to her liking. Whether to rid herself by fair means, or by foul, of her unwelcome quest, "that is the question." By alarming, to drive away, she might bring the creature in her very face, or on her very back ; better at once to "end it." So Deborah screws up her courage,--seizes on a knife,-approaches with a murderer's step her now quiescent vietim, and with a dexterity, under existing circumstances, perfectly miraculous, severs its head from its body. Then, as though a coffin had popped from out the grate, bounds the plump person of Deborah from the dresser with a piereing scream. Most marvellous!-most horrible!-She hears again, louder and more doleful than before, that melancholy cry, and it is the moth's bodiless head, or headless body, from whence it issues. Snap!-like her jack-chain in the morning, had gone the spring of Deborah's wound-up courage; but now desperation solders it together, and, after a stop, her bodily machine is once more in motion towards the dresser. She lifts the candle-holds it nearer to the object, the now twofold object of her terror-she looks-she listens-perhaps her ears, or eyes, or hand, had played her false;-but, no! they and her murderous weapon had all been true:-here lies the 
head, there the body,-and, sure enough, too, the head still wails as if in suffering, and the body heaves, and the dark wings quiver, as if in indignation. But it is not alone these quivering pinions which impart a motion like their own to Deborah's whitened lip. It is not even the wail of that disserered head which causes her heart to beat like a muffled drum, in accompaniment of its plaintive pipe ; but she seesshe sees, plain as the effigy on Master Thomson's new tombstone-right on the creature's back, between its shoulders, another head-an eyeless skull-magnified, by terror and consciousness of cruelty, into size above the human. Poor Deborah beholds no more-she has scen and heard too much, and falls, plump as her person, on the kitchen floor. There her mistress, after having by reiterated peals broken the parlour bell, was the first to find her. In due time, this veracious tale of wonder was gathered from the domestic's lips; and in the mutilated object of her alarm, was discorered the decapitated corpse - of a Death's-head Moth.

Next, in the power of raising superstitious terror, and, as more common than the last, an agent of creating it more extensively, comes the "Death-watch," that pocket time-piece of the grisly monarch, heard, not seen, whose measured ticktick-gives warning of its master's soundless footsteps. What hollow echoes are awakened by this monotonous midnight music ! Screwing down of coffins-rattle of earth above them -toll of the funeral bell-salute the trembling ear; while 
correspondent phantoms-sheeted corpse and shrouded skeleton-start into lifeless motion before the glaring eye. Such, as seen and heard through the magnifying haze of ignorance and twilight, or heard only in the dead stillness of the midnight hour, are the death's-head moth and the death-watch beetle.

Let us now inspect them in a calmer and clearer manner.

First, for the Death's head - the Sphinx or Acherontia Atropos of the entomologist. And here, in the largest of British moths, we have a beautiful insect of richly variegated plumage, -bird-like in magnitude - the "wandering bird" of Poland.

In the upper wings, which, when expanded, cover an extent of nearly five inches, the prevailing hues are very dark, but elegantly disposed in waves and shades of brown and black, broken by a few lighter clouds, and one small white spot near the centre. The secondary pinions, of less sombre colouring, are of a deep ochreous yellow, barred with black; a livery in which the massive body is also attired. The head and thorax are dark, and it is on the back of the latter that the insect bears its dreaded badge, the death's head, to which it owes its name, figured in yellowish grey upon a sable ground.*

The power possessed by the death's-head of emitting sound (a gift rarely, if at all in any other instance, bestowed upon its race) gives to this singular moth another fancifully imputed attribute of the supernatural; and the character of its voice, if voice it may be called,--loud, shrill, and wailing,-invests 
it with an accordant tone of evil augury. However fanciful its prophecy of ill to others, the lament of this unusually complaining creature would seem to be a real expression of being ill at ease itself, since, according to Réaumur, when "shut up in a box, it cries; when caught, it cries; and when held between the fingers, it never ceases crying."”

Naturalists have been sorely puzzled and widely at variance as to the organs producing this frequently-employed voice. One supposes it to proceed from the body; another thinks it is produced by friction of the chest upon the abdomen, the wings having nothing to do therewith; a third, tout an contraire, supposes he has discovered the organs of sound in a pair of scales at the wing's base, played upon by the action of the pinions themselves.* Réaumur opined that the cry proceeded from the insect's hearl, its immediate source being the friction of the palpi against the tongue. Passerini, Dumeril, and Duponchel have traced the origin of the sound to the interior of the insect's head; from which, according to the statement of the latter, the sound continues to proceed on separation of the body.

let later than all the above varied opinions, and only accordant with one, comes that of Mr. Denny, according to which, the true organs, producing the death's-head's melancholy strain, are two large moveable horny scales, at the bases of the upper wings, fixed on the thorax, and covering each a 
small aperture, which is also a horny substance. In proof that the vibration of these scales causes the sound, it is stated that during its emission they, only, are in a state of strong vibration, while all other parts of the insect may be at rest.

There is another singularity, noticed by Curtis, in the history of the death's-head moth, which presents another curious correspondence with its funereal character. One of these moths, on bursting from the chrysalis, which is always found buried in the earth, was observed by the above naturalist to be enveloped, to the head, limbs, and antennæ, by a fine membrane, like tissue paper, which dropped off as these gradually unfolded-even as a shrouded body, on bursting from the tomb, might cast off the cerements of the dead.

The wings of the above specimen, as usual on emergement, were not larger than a finger-nail; but the insect having: speedily placed itself in a position to admit of their hanging down, they were soon injected with air or fluid, and in two hours perfectly expanded. The "Death's-head," of which the female is the largest, excels in size, not only every British, but, with the exception of the "Peacock," every European moth.

September, or the present month of October, is the season, usually, when the Acherontia Atropos assumes its winged form, and may be found, occasionally, resting in day-time upon trunks of trees, or, attracted by the taper's light, visiting our houses, where their phantom forms are, now, much oftener weicomed for their rarity and real beauty than dreaded for 
once imputed terrors. Only to the people of the hive (as we have elsewhere noticed) have the terrors of the death's-head any real foundation, when, as the "Bee Tiger," he carries dismay into the waxen city, and, under cover of his awestriking voice, he pillages, with impunity, its honied stores. Although, as such felonious act is sufficient to testify, the Acherontia Atropos is a prodigious lover of honey, he is not provided with the long tubular trunk wherewith the true hawkmoths are accustomed to rifle flowers, having in its stead only a thick, stiff, short proboscis ; more convenient, therefore, for insertion into comparatively shallow cells than into deep nectaries. The antemne of the Ackerontia are also short,another distinction from the Sphinxes, with which it used to be, but is not at present, classed.* Hidden under some shady covert from "the garish eye of day," the death's-head is accustomed to take wing in the evening and morning twilight. It is usually a solitary visitant; but a common attraction has sometimes brought together companies of its kind. So large a number are said, for instance, to have been once drawn to a lantern on board a vessel at anchor on the coast of Devon, that a dozen were hunted down by the sailors. If they had known the character of their game, we doubt if our honest tars (superstitious as they once were, and still, to a degree, remain) would not have cared less to have been boarded by a dozen Frenchmen. Stephens makes mention of four being 
captured out at sea. The ignorant fears excited by these remarkable moths have assumed, in different countries and times, various forms of absurdity. In the Isle of France, as we are told by St. Pierre, the dust from off the wings of the death's-head was believed to cause blindness, merely by flight through an apartment.

Invested, through the mortal emblem on its tabard, with the imaginary office of herald to the Fates, disease and death were anticipated in the wake of its heavy pinions, or thought to be announced by its mournful cry. A whole sisterhood of nuns could be terrified by the apparition of a single death's-head within their holy precincts; and a parish priest, desirous to work by terror on the consciences of his flock, could find for his purpose a powerful instrument in the appearance of this harmless insect, which, in the year 1730, was described by a curé of Bretagne, as "revêtu de tout ce qu'une pompe funèbre offire de plus triste." Even its wings appeared to his deluding or deluded fancy, to be "marquetées comme une espèce de drap mortuaire."

The educated bigots, who lived in the days of Réaumur, could hardly help being, themselves, comparatively enlightened as to the natural causes of certain phenomena looked on before as the work of devils or of sorcerers, such as the shower of blood at Aix in 1608, discovered to be the production, not of demons, but of butterflies. But nothing made these tyrants of the soul more angry than the boldness of adrancing science, 
threatening, as it did, to rob them of a monopoly of bugbears, sprung of ignorance,-to wrench from their grasp a varicty of rusty weapons, such as they had been used to wield for the subjugation of minds yet darker than their own. Thus wrote, in 1735, the journalists of Trevoux, in comment on another shower of sanguine hue, like the one of 1608, and occasioned, like that, by discharges from butterflies on emergement from their chrysalides. "Le public a toujours droit de s'alarmer; il est coupable: ct tout ce qui lui rappelle l'idée d'un Dieu vengeur n'est jamais un sujet faux, de quelque ignorance philosophique qu'il soit accompagné." Truly a precious doctrine of darkness and distortion! and who can read it without being thankful that with us, at least, the reign of superstition, as a reign of terror, is near its close? Some superstitions one may venerate, others one can scarce help loving; but such as the above-such as would derive, even from the most beautiful and innocent of God's creatures, ideas of an avenging Deity, instcad of an all-merciful and beneficent Creator -thank Heaven, such inculi have nearly taken flight!

The caterpillar of the death's-head moth is one of the largest and most beautiful of its tribe, and presents, in its brilliant colouring, a striking contrast to the lugubrious colouring of its perfect form. It is of a fine yellow, obliquely barred by seven green stripes on each side, with intervening lines of blue and black spots. It has the pointed tail-like horn common to hawk-moths, and is enduwed, moreorer, as in 
its perfect state, with the gift (boasted, we believe, by no other caterpillar) of a voice; for it is said by Kirby that if disturbed, it draws back rapidly, and emits a loud noise, which may be compared to the crackle of an electric spark. Its favourite food is furnished by the leaves of the jasmine and potato; and, with the increased cultivation of the latter, the death's-head has become of late years less scarce than formerly. The caterpillar is said to feed also on hemp, elder, and the woody nightshade. It is mentioned in the "Cambridge Chronicle' of September 1846, that Mr. Denuy took twenty of the full-grown larvæ from off a tea-tree, growing on the top of a house at the back of Downing-terrace, all of which he successfully reared into splendid specimens of their kind.

These caterpillars, as well as various others, are apt to elude the search of the collector by taking refuge during daytime from the sun's rays and the darts of iclmeunon-flies, not merely under the leaves they feed on, but in the earth beneath them. To the same bed they retire towards the end of August or beginning of September, and, forming therein their smooth untapestried chambers, put off their gay attire for chrysalidan covers. From these, as we have seen, they burst in autumn, harbingers of wintry death, at least to the vegetable world.

The ominous Deatll-watch, when drawn from its hidingplace in old perforated floor or wainscot, picture-frame, cliest, or black-lettered volume, comes forth (a mouse from a mountain of fear!) a tiny beetle of some quarter of an inch in 
length, and in its prevailing hues of grey and brown resembling the colour of the time-worn wood, whose decay they help (especially in their grubhood) to accelerate. That alarming " tick," to which at midnight many a timorous heart has beat in unison, is generally to be heard first in May, and on to autumn, by day as well as night, and, being considered analogous in purpose to the "call" of pairing birds, has, in rcality, as little of ominous about it. The sound is not vocal, but consists of a series of quick successive beats, produced, usually, by the striking of the insect's mailed head upon the hard substance whereon it may be standing, or into which it has penetrated, most likely, while a grub. Some have supposed the grub itself to be the drummer, but, if this sometimes be the case, the perfect beetle is a drummer too, various accurate observers having been eye- as well as ear-witnesses of its performance.

There are various species of these ticking, or more properly beating, beetles, of the genus Anotium, of which a marked characteristic is the concealment, nearly, of the licad beneath the thorax. Amongst these, two noted drummers are distinguishable by their uniforms-in other words, by the markings of their wing-cases,-which in one ${ }^{*}$ are striated, in the other $\dagger$ tessellated. Another, of a plain dark brown (Anolium pertinax), frequent in holes of old wood, has long been famous for its pertinacity in simulating death, and for displaying a 
seeming indifference to torture, comparable only to the American Indian. De Geer affirms, upon experiments which it needs not to repeat, that "you may maim, pull limb from limb, or roast over a slow fire this pertinacious creature, and not a joint will move in token that it suffers. A curious instance, this, of the unconquerable power of an instinct implanted for self-preservation."

However insignificant in their imputed attributes, these wood-boring beetles are by no means despicable in their actual proceedings. Where abundant, not only chairs, tables, and books have been reduced to powder, but even buildings have suffered from their combined agency. Curtis mentions the roof of King's College, Cambridge, having been seriously damaged by their operations, and thinks that the same species (the Anobium tessellatum) has been known to cut through sheet-lead. He had himself seen tinfoil perforated by the grub of another species, also an underminer of floors, a destroyer of herbariums, and of ship-biscuit.

Besides the above, there is another insect death-watch, in the ear of the vulgar of very similar and, doubtless, confounded sound, although, in the eye of the naturalist, it is a piece of living mechanism of make and structure altogether different. This is no ticking beetle, but a ticking wood- or timber-louse - a Termes, allied to those far-famed destructives, the white ants of Africa and Southern Europe. Mr. Rennie thus describes it:- "It is not so large as the common louse, but 
whiter and more slender, having a red mouth and yellow eyes. It lives in old books, the paper on walls, collections of insects and dried plants, and is extremely agile in its movements, darting by jerks into dark corners for concealment. It does not like to run straight forward without resting every lialf second, as if to listen or look about for its pursuer, and at such resting times it is easily taken. The ticking noise is made by the insect beating against the wood with its head; and it is supposed by some to be peculiar to the female, and connected with the laying of her eggs." **

The ticking of this apterous death-watch, instead of being repeated at intervals a certain number of times (usually from seven to eleven) as that of the beetle, is continued, like a veritable watch, without intermission.

Such is the living main-spring of the death-watch when taken from out its wooden case; and though all its terrors vanish on bcing brought to light, it is easy enough to account for their origin in connection with place, time, and circumstance.

Most heard in old (perhaps haunted) houses, proceeding from wainscot or from bed's head, perhaps from picture-frame of grim old portrait, as if the "tick, tick," of the invisible time-piece issued verily from the laced fob-pocket of some buried ancestor; or heard, possibly, with creeping awe, to proceed, "tick, tick, tick," from the elm-wood of a coffin 
before consigned with its mute tenant to the earth ; heard, too, by night-wakers, the sick and the solitary, or night-watchers keeping their vigil beside the dying or the dead,-who can wonder that, with such concomitants, the hearts of the ignorant should have often, and may sometimes still echo, fearfully, the beat of the death-watch? And, perhaps, with all our little knowledge, our own might, under the like circumstances, do the same.

Thus much for the wailing pipe and monotonous tabors of our "Insect Dirge-Players."

It has sometimes been objected, that in leaving no holds for superstition-in pulling her down from every dark corner, where, bat-like, she still clings-we clip at the same time the lightsome wings of fancy; that in correcting popular errors, we lessen the number of poetic associations. But it is not so, at all events, with associations of the brighter kind. To bring examples from our present subject, the mind emancipated by knowledge may cease to feel terror from the performances of our "Insect Dirge-Players;" but does it, in its freedom, respond less gladly to the more cheerful strains of "Insect Minstrelsy"? If we may not, properly, continue to designate as a "song," or as a "chirp," an instrumental sound produced by attrition, as that of the grasshopper; does the grasshopper's rustic strain lose, on that account, its pleasingly associate character? Does it not, on the contrary, gain another feature of highest interest in connection with the 
Divine mechanism which makes it audible? The same applies to the cheery hum-poetically, the "vocal wings" - of the bee, and to the music of all

"Those fairy-formed and many-coloured things, Who worship [God] with notes more sweet than words."

Because we may happen to have a notion from whence springs the melody of insect choirs, need we the less admire with that master mind-the leading mind for awhile of an cmancipated nation-

"Comme ils gravitent en eadence,

Nouant et dénouant leurs vols harmonicux!

Des Mondes de Platon on eroirait voir la danse, S'accomplissant aux sons des musiques des cicux."*

Science, in removing partially the veil which conceals from us the mechanism of created things, leaves them still invested with every charm thrown around them by the imaginative mind. Nor need the rout of superstition-which is only imagination in a distorted form-loosen one legitimate tie betwixt our visible earth and the unseen worlds of which ours is a type. 'That, truly, is a connection which, by every excitement, save that of terror, it is well to keep up; and for what, but for this end, has imagination been numbered amongst our faculties? Let us, then, cultivate this precious gift, which has the power of investing the meanest objects of sight and hearing with beautiful associations, and not this only, but of 
converting them also into mediums of intercourse with things unseen, existing within and around us. But let our imaginative regions, which in all but material substance may be regions of reality, be never peopled by the dark appalling visions of a distempered fancy. Let us, rather, through the visible millions which fill the earth and sky with insect music, be led to a pleasant but chastening consciousness of the presence of those " millions of spiritual creatures" which

"Walk the earth

Unseen, both when we wake and when we sleep ;"

and whose appointed office, besides that of " singing their Great Creator," may be to fill with harmony the moral clements which make our world of mind.

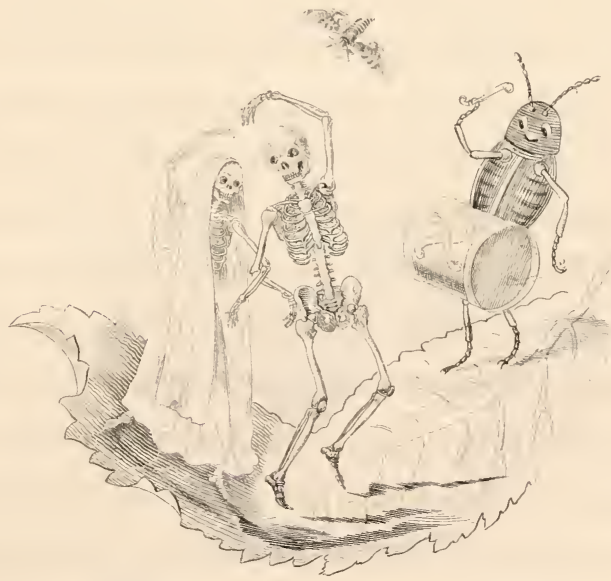

H. bantoms fout if to the Deatly-untely trum 


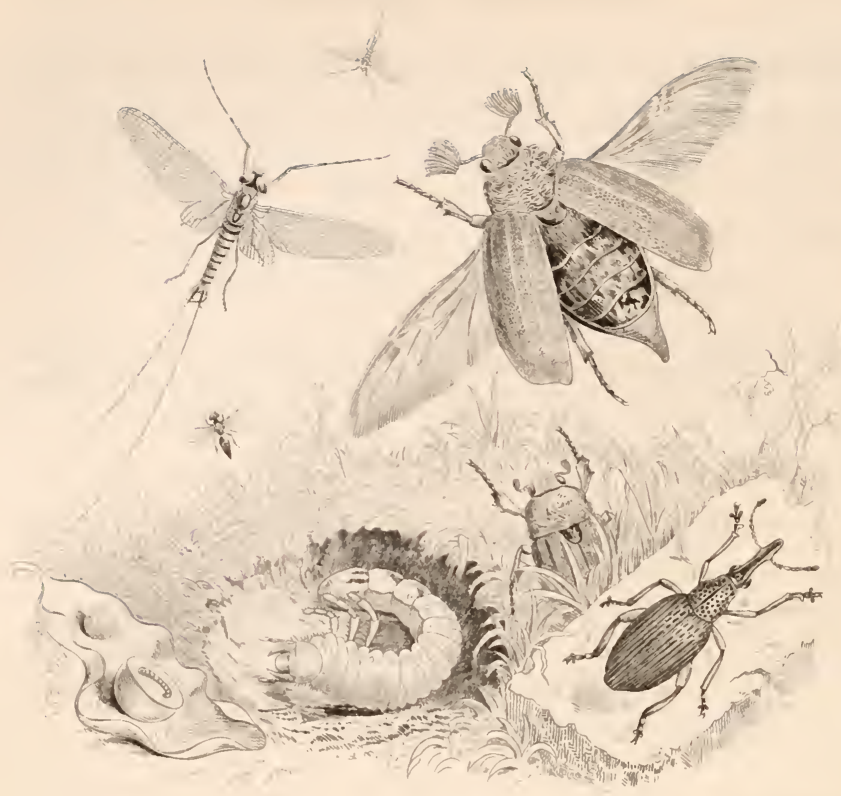

\section{SHORT LIVES AND LONG.}

"Loveliest of lovely things are they

On earth, which soonest pass away."

"Here lies the man-was born, and cried:

Lived sixty years-fell siek, and died !"

Oun chosen emblems of fragility are flowers; and, fixed by the laws of their creation to one spot, where they bud, and bloom, and wither beneath our eye, we have been compelled, almost, to notice their brevity, and are sensible, at times, of the moral odour which exhales from the union of their beauty and fragility. 
In the world of insects, examples of existence, bright and brief and most precarious, are no less common, and in many respects (especially as occurring amongst sensitive beings) infinitely more striking; but, except with those sporters of a day, hence called Ephemera, the frail tenures of insect life seldom serve to remind us of the like nature of our own, and chiefly, perhaps, for the following reason. Many a brilliant flutterer is cut off in the midst of its joyous activity, much more suddenly than the flower over which we have seen it hover, but ere the scattered petals of the one have strewed the surface of the ground, the wings of the other have borne it to die unseen within some hidden covert; or, contributing in death to the support of life, it may have sunk suddenly into the devouring gulf of some insectivorous bird, or carnivorous feeder of its own race.

It is, by the way, a remarkable dispensation of Nature's Author, and one equally beautiful and kind, that while. Death is for ever busy, as elsewhere, in the lower departments of the animal kingdom, so few of the victims they afford him are permitted to offend the eye in any shapes of disgust or danger. To confine this observation merely to insects :-We see the air teeming with gnats; the ground populous with ants and beetles ; the fields, especially towards the end of summer, alive with grasshoppers and Tipulidan flies; the hedges, through the months of June and July, scarcely more abundant in leaves than in the smaller moths, which in daytime make a covert of VOL. III. 
their foliage : and of these countless myriads we are told, truly, that even of those among them permitted to reach their good old age, scarce a single gnat survives a week; not half the beetles, nor any of the Tipulce, nor grasshoppers, a month; while few are the butterflies or moths which orer-live a fortnight. What has become of them? may naturally be queried by those who bestow upon the subject a mere passing thought; and though with those who have learnt something of insect history the marvel is greatly diminished, it still remains matter of some surprise, that of the myriads which dic daily round and about our paths, so few "mortal remains" should meet our eye. Something, in short, of the same sort of mystery is attached to their entire disappearance as that which seems to have been noticed by some of old Fuller's "worthies," with regard to the disappearance of pins, which caused them to admire " that so many millions of these useful and neat little articles made, sold, used, and lost in England, should ranish away invisible ;" to the which remark, our excellent divine, with gravity becoming his profession, and quaintness belonging to his style and character, appends this serious reflection:-that " such persons may rather wonder how so many that wear them, being no more than pins in the hand of their Maker, do decay, die, and slip down in the dust in silence and obscurity."

The duration of insect life varies greatly; but there is one remark respecting it of very general application:-Its last and most perfect stage is usually the most brief, often immensely 
disproportioned to those which have preceded it. To adduce only a few examples.-

The great goat-moth,* while yet a caterpillar, occupies, in solitary darkness, the trunk of willow, oak, or poplar. For three successive summers it is employed in eating into the solid wooden barrier which divides it from the sunny world,for as many winters it sleeps within one of the dark tumnels thus excavated by its powerful jaws; but after this extended period of repletion and repose, it scarcely lives over the same complement of weeks to exercise its broad, dusky pinions in the summer moonlight.

Other moths and butterflies remain various periods, but frequently months, and sometimes years, in their aurelian state of semi-torpor, while few of them are permitted to enjoy their flitting delights for much longer than a fortnight.

The same is exemplified in various beetles. The cockchafer, $\dagger$ as a grub or larva, first opens its eyes on the darkness of a subterranean nest under the surface of a meadow, where, with its numerous brood-brethren, it subsists (often to the farmer's serious injury) upon the roots of grass. Unless unearthed by ploughshare, snout of swine, or bill of bird, the grub of the chafer thus continues for four gloomy years working his covert mischief; but when arrived at the maturity of his beetle form, he only feasts upon foliage, and travels, whir- 
ring, through the air, for eight or nine successive evenings of the month of May.*

We have noticed, already, that the brilliant Ephemera, which, in its winged prime, seldom lives long enough to see both rise and set of sun, has previously existed for two years and upwards as an earth-caverned dweller in some river's bank.

Again,- the little gall-fly, as a grub, occupies, often for six months, its secret chamber in the heart of an oak-apple or other gall, while a few days suffice to terminate its winged activities.*

Similar examples might be multiplied, but the above serve sufficiently to illustrate the position that insect life is usually the most brief in its last and brightest stage, affording, in this respect, a contrast, instead of a symbolic parallel, to the history of a beatified soul.

A few instances do, indeed, occur, of insects being very long-lived after their attainment of a perfect form; but these are, for the most part, to be found, not among the gay and gaudy flutterers of air-not among the livers upon sweets anbrosial quaffed from painted flower-cups, not more fragile than themselves-not among the baskers in the sun, or the sporters on his beams; but rather amongst the dull, lugubrious, sobersuited crawlers which lurk in the dark places of the earth and the dark corners of our habitations.

The churchyard beetle (Blaps mortisaga), at whose very * See Vignette. 
name an involuntary shudder passes over one, has been kept alive, without food, for three years, and may perhaps be a longer liver in its own locality of death.*

An individual spider may often, it is probable, live long enough to lie in murderous wait for flying innocents, even to the fourth and fifth generation. Goldsmith, indeed, mentions one as having lived three years; and though his authority on this, as well as on other matters, especially of natural history, has been often called in question, $\Lambda$ udibert is also stated to have kept another quite as long.

Some of the weevils-a tribe of beetles distinguished by their long beaks, or rostrums-can also boast themselves of a span of life comparatively long. One of these, found upon rotten wood, the substance which it feeds on, we have kept under a glass from June to the April following, when it escaped. This, also, though it has not once grown torpid, may be considered as an insect of gloomy and retired habits, and, like others of its family which live in wood or earth, is of sombre dark-brown hue $; \uparrow$ in this respect, strikingly contrasted with the gayer colouring-usually a vivid green, sometimes reddisplayed by that more cheerful division of the same tribe, which is used to frequent and feed on trees and plants, in open daylight, and which die, probably, with the leaves and stalks whose sap constitutes their wine of life.

It would seem, then, that the highest apparent degrees of

* See Vignette to 'The Scarabrus.'

$\uparrow$ See Vignette. 
vitality, sensitiveness, and enjoyment, are seldom, in insect life, made to consist with long duration. With them, to live long is not always to live much, though we may justly say of them, as of other and higher existences, that to live much is to live long.

The Ephemera, * for instance, in their single day of light and love-as tenants of the air-may be said to live longer than in the darksome years of their immurement within earth and water; while the butterfly, fluttering over the flowers of the grave, may enjoy more of existence in that short half-hour of sport and sunshine, than the churchyard beetle in the whole course of its buried career amongst the relics of mortality.

In this seemingly disproportioned, yet in reality well-balanced allotment of insect life, there exists, as we have noticed, no parallel with the history of the soul, viewed as an immortal principle; but amongst the instances just adduced, as well as a thousand more, there is not wanting a very marked correspondence with the earthly tenures of human cxistence as most usually holden.

Which are the lamps of clay found, commonly, to be the soonest broken, and most early committed to their congenial soil? Common observation answers, Those, certainly, in which a brilliant flame has served to exhaust most speedily the animal oil whereon it fed. George Herbert said of himself, that he had " a wit, like a penknife in too narrow a 
sheath, too sharp for his body ;" and the remark is of general application.

In the case of our old poet and divine, the "sheath," indeed, proved of tougher material than he seemed to anticipate, for long afterwards, writing about spring flowers (those favourite emblems of fragility), he says beautifully and devoutly-

"And now in age I bud again,

After so many deaths I live and write;

I once more smell the dew and rain,

And relish versing. Oh, my only Light!

It cannot be that I am he

On whom thy tempests fell all night.

"These are thy wonders, Lord of love!

To make us see we are but flowers that glide,

Which, when we once can find and prove,

Thou hast a garden for us where to bide."

Opposed to those who, whether their span of life may have been short or protracted, have lived, like the active May-fly, all through their day, there are multitudes over whose remains the epitaph (from Camden) which heads our observations might seem appropriately placed.-

"Here lies the man-was born, and cried,

Lived sixty years-fell sick, and died."

Yet is even this, on our present principle of reckoning, a memorial by far too eulogistic. "Lived sixty years!" Why this crawling creature, who ate and slept away existence, did not live sixty years, nor a sixtieth part of them. Only compare the weary grub.like stage of such a creeping dullard, 
with the winged career of a Chatterton, a Kirke White, a Shelley, a Keats, and other brilliant Ephemerce of a poetic sky, and say-if life be computed by the amount of actual living, by state, which, to mind, often annihilates and stands in the place of time, by spiritual measurement instead of by finger calculation - whether the balance of longevity, in its proper sense, may not incline rather to the span of twenty than of sixty years.

We are all accustomed to talk of variety as though it were a spur to time; yet must we all have noticed that time is seemingly prolonged (especially in retrospect) by the occurrence of incident. The year wherein much has transpired, whether for weal or woe, always seems longer than those wherein nothing has happened to disturb the even tenour of our way; and the less varied be the common character of our paths through life, the more swiftly do we seem to traverse them, even if we complain of dullness by the way. But it is number and variety of ideas and feelings which, yet more than those of incident, serve to make the most of time; consequently, if we desire to live much-in other words, to live long-we should lose no occasions of cultivating growths of thought and interest. Instead of passing in the wearying swiftness of half-conscious apathy through the scenes and by the objects of nature, let us invoke all the exhilarating and life-giving influences which their bountiful Designer intended them to convey. Let us do this always, though we may find it most easy in 
the spring-time of our lives, and of the year,-those especial " times for feeling," when we can say with the poet,

\section{"One moment now may give us more}

Than fifty years of reason;

Our minds will drink at every pore

The spirit of the season."

Many curious experiments have been tried successfully in the prolongation and curtailment of insect life. In some cases, starvation, that agent, usually, of destruction, has been found, by retarding the completion of its accustomed stages, to lengthen the journey of existence to our little fellow-travellers. The larva of an aphidivorous fly, placed by Kirby under a glass, where it was left inadvertently without food, was found alive three months afterwards, living eight times as long as it would have done in the combined periods of its usual uninterrupted stages.

Cold was also an agent employed by the French naturalist Réaumur to retard the emergence of butterflies from their aurelian cases, and thus prolong the duration of their life-if we may apply the term to a state of apparent torpor. The chrysalis of a nettle butterfly, which usually emerges in a fortnight, being placed, with others, in a cellar, remained two months before exclusion.

On the other hand, by the agency of heat, the naturalist -who, through the exercise of this curious power over life and death, would seem, in a measure, to command nature- 
can abbreviate instead of prolonging the term of existence. Enclosing his chrysalides in the interior of a glass egg, Réaumur called in the assistance of a brooding hen to liatch the butterflies he willed into a prematurity of perfect form, some of which appeared, accordingly, in four, instead of fourteen, days. Others, in a similar state, being placed in a hothouse, were forced to expand amidst the snows of January the wings which, in the course of nature, would have fanned the flowers of May; and the life of the perfect insects remaining the same, the sum total of their existence was, of course, proportionably shortened. It is observed by Kirby and Spence, with reference to these experiments, that Paracelsus would, on this discovery, have renewed his seareh after the elixir of immortality; and Réaumur himself appeared to view, as something a little more substantial than mere chimera, its possible application to mankind. He had also found that by varnishing the skins of chrysalides, so as to prevent absorption, the appearance of the winged insect was retarded for two months; whereupon, reasoning by analogy, he supposed that human existence might be lengthened in like manner by the checking of perspiration, suggesting, gravely, that the experiment might be tried on condemned criminals. The encouragement of transpiration, by means of warm clothing or other appliances, he considers, on the contrary, as likely to abbreviate our natural term.

From experimental fact and philosophical deduction, the 
lively French naturalist wanders into imaginative speculation on the probable results of some such life-influencing power in its application to the human race. First, in the case of abbreviation : "A child," he remarks, "would have little reason to complain of a father who might be enabled to force him, in a few weeks, into a maturity of endowment, bodily and mental." He says, "Qui nous ôterait nos premières années, qui les ferait passer en quelques jours, nous ôterait peu. Qu'estce que c'est que de vivre alors?" Who but a Frenchman, one of the French noblesse, too, of the eighteenth century, and (admirer of nature as he was) a member, therefore, of society most artificial, could have put the question? What is it to live in our sweet days of childhood? It is to gather the first and freshest of spring flowers; to sip the sparkling surface of a draught which begins to grow vapid even before half-exhausted. So, at least, would most of us reply, on looking back from an advanced station on the earliest stages of our journey. It is likely, however, that if the infant, the school-boy, and the youth, could each respond to the question, "Qu'est-ce que c'est que de vivre?"- "What is life to you?" the infant would lisp- "It is to be pricked by an unsuspected pin, and slapped by nurse for crying at the smart." The school-boy would tell us- "It is to dream of home an hour too long, and creep down on a January morning an hour too late ;" and the smart lad or forward little miss in teens would reply, "It is to be called a child for ever." These, therefore, 
under the present pressure of their "pinching shoes," would be likely enough, if the scissors of the Parcæ were placed in their own hands, to snip off the first few yards of their respective threads; but they would have reason to repent them sorely of the act; for admit we even that the season of our early spring-time, so bright when looked back upon, is yet so chequered with passing clouds, that its actual amount of sunshine is no greater than in those that follow, what would those others be without it? Where, then, the first recollections of innocence? Where the first lessons of maternal tenderness? and where, in their absence, those gushing life-springs of the soul, so pure and so deep-seated, which, through the crust of maturity, however hardened, do, at times, wcll up within us and prepare our hearts for the reception of dews divine, perhaps more directly shed, but not of origin more holy?

So much for the curtailment, at its commencement, of life's unfolding roll; and the power of its voluntary extension would, we fancy, prove a privilege scarcely more desirable.

To put a case parallel with the artificial lengthening of insect life, we must, of course, suppose the extra period to be passed in a state of torpor. On these terms, the addition even of centuries to our three-score years and ten may appear only a nominal gain, since, as our French naturalist justly observes,- "It is only the conscious train of thought and feeling which constitutes our real existence." To some people, however, he adds, it might appear exceedingly agreeable to 
live, even on the condition of torpid intervals, for ten or twelve ages, having in each a few years of active life.

What changes in the face of nature, art, science, manners, tastes, and fashions would such persons behold; and how, in all these matters, would each succeeding period enlarge upon the tale of wonder told by its predecessor !

Only imagine a courtier, a lord in waiting on King George the Third or his consort Charlotte, awakened from a nap of only fifty years, to fill the like office in the court of our Sovereign Lady. Verily, upon opening his eyes on the strange things around, they would be stretched beyond power of reclosing. Suppose him called on to attend the Queen in one of her frequent "progresses ;" well might such a sleeper awakened rub those distended eyes, and doubt his wakefulness, on beholding his royal mistress step into what appears to his bewildered sight some palace of enchantment, wherein she, and he, her astonished satellite, are forthwith whirled along; by - what? surely, he believes, by some obedient slave, invisible, of lamp or ring; for how can he have dreamt, in his dreamless slumber, of the slave of the kettle-that giant genius, Steam, which had arisen, while he slept, at the bidding of the magician, Science, to make a button, to compound a pill, and to transport a sovereign?

Or suppose an individual of the present day, thrown by mesmeric or ethereal influence into a deep, dead, bonâ fide slumber, for the remaining half of this nineteenth century, who 
shall venture to imagine the astounding marvels on which his eyes would open at the beginning of the twentieth? Marvels, vastly curious and amusing in the speculative distance, but of which the close reality might be attended by various sensations something less agreeable. The old-fashioned courtier would feel awkward enough in the position we have just supposed amongst his modern brethren of the suite; but how infinitely more so one of these latter under circumstances wherein the lapse of another half-century might place him, when called on, perhaps, to attend his sovereign-if sovereigns there be, or if sorereigns then have lords in waiting-in a state balloon!

Still worse might it fare with the present great heads of law, plyysic, and divinity, who, on re-opening their eyes in the year 1900, might each, peradventure, find his "occupation gone"-the lawyer, in the march of Christianity ; the doctor, in the march of mesmerism; the church dignitary, in the march of simple gospel truth.

But disagreeables like these would be but trifles compared with the serious perils to which a life-spinner, such as we have pictured, would be exposed during his state of roluntary torpor. To preserve him from accidents by flood, fire, and steel, he might prepare himself, beforehand, a temporary tomb of refuge, wherein he might depend, possibly, on being well secured. But who could he rely on to revoke his soporific spell at the end of its desired period? Hardly the heirs of his property, or its stewards; or even, if, on composing himself for his pur- 
posed nap of a half-century, this individual had left in wakefulness a disinterested descendant or a fast-enduring friend, that rara aris might either be, in the course of nature, dead, or choosing, like himself, to deviate from her beaten track, have repaired, like a sand-marten or a great goat caterpillar, to his own dormitory, and be, therefore, out of the way when his liberating services were required. On the whole, then, and in sober earnest, we must needs arrive at the conclusion that, with the allotted period of our lives, and their present constitution, as with all other things.under the guidance of Infinite Wisdom, whatever is, is best. Above all, let us remember, that, even as it is, we are permitted, in one important sense, to hold in our hands the extension or curtailment of our allotted span. Within a brief space, we may live much,within a long one, olı! how little!

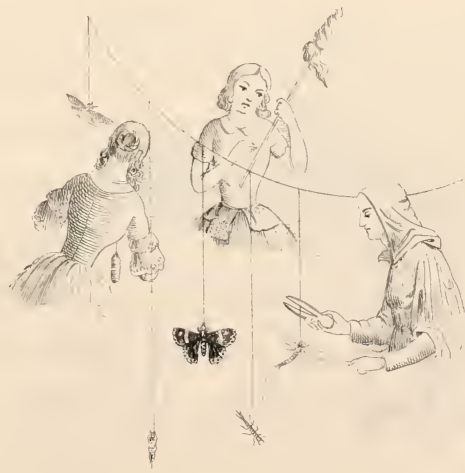



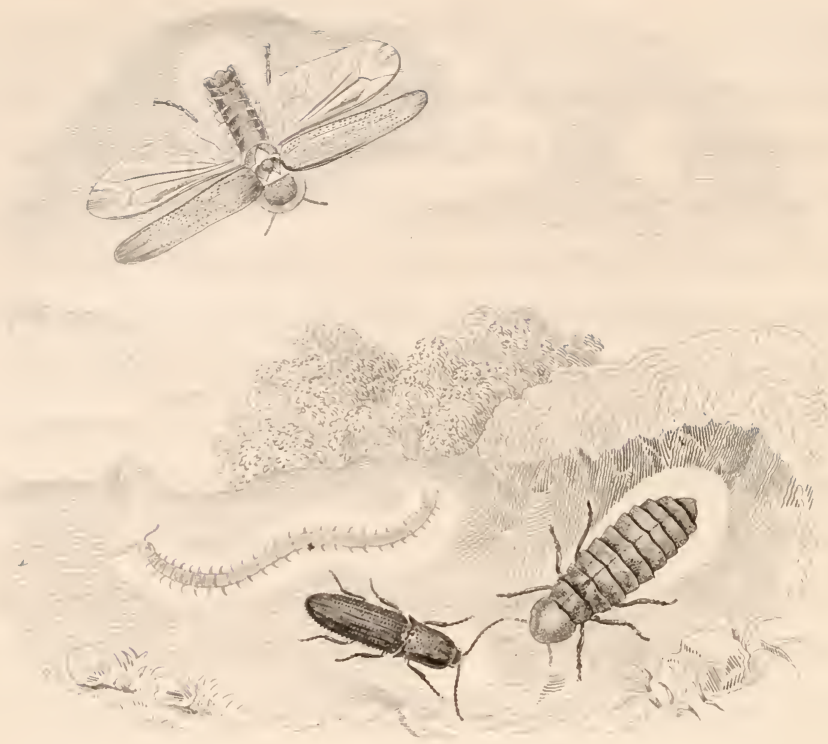

STARS OF THE FARTH.

"Among the crooked lanes, on every hedge,

The glowworm lights her gem, and through the dark

A moving radiance twinkles."

"Voir au ciel briller les étoiles,

Et sous l'herbe les vers luisans."

Besides alnost every other object in the world, its various luminaries, both natural and moral, find their representatives and symbols in the insect creation. The fixed, or as it appears to our childish and, what is nearly the same thing, our unreflective view, the little twinkling star, is emulated by the 
modest radiance of the glowworm; the planetary bodies, for ever wheeling in their orbits, are better represented by the restless fire-fly ; whilst the streaming meteor and blazing comet find their prototypes in the brilliant Fulgora, or Lantern-carriers, as described shooting in eccentric courses across the gloom of tropic skies.

Then, for the luminaries of the world considered morally, we shall be at no loss to find symbolic parallels in the varied qualities, habits, and localities of luminous insects. Our little English glowworm, as she glimmers on her mossy bank, how well, to borrow the words of a late lamented poet, * does she serve to represent those quiet Christian spirits, who

$$
\text { " in humble trust }
$$

Shine meekly 'mid their' native dust, The glowworms of the earth!"

And if, as opposed to these modest "lights," we desire correspondents for the "stars" of the world, we may scarcely find more apt ones than in the great lantern-flies, the radiant uproarious night-singers, the scare-sleeps of Guiana, bearing aloft their fiery flambeaux, like torches of noisy revellers, and grating on the "ear of night" by the harsh music of their loud discordant cymbals.

The attention of philosophers was in very early ages directed to various phenomena resulting from the properties of light, and, amongst others, the remarkable phosphoric appearances

* Wordsworth. 
of certain animal and vegetable bodies. Ancient writers allude in general terms to the existence of luminous insects, of which the species most early known is supposed to be the Linnæan Lampyrides, or flying glowworms, abundant in the south of Europe, as well as in Asia and some parts of Africa. The Greeks included all shining insects under the name Lampyris, and the Latins called them Cicindela, Noctiluca, and Luciola, under which latter designation the flying glowworms are still (as wc have seen) known in Italy.

With the Fulgora, or lantern-flies, the ancients are thought to have had no acquaintance, for, though Asia produces a few species of them, the most remarkable are peculiar to the warmest parts of America. These singular insects are supposed, indeed, to have been quite unknown in Europe till the latter end of the 17th century, when Madame Merian, in her beautifully illustrated work on the Insects of Surinam, and Dr. Grew, published histories and figures of the lantern-carriers, which, by the sceptical of their time, were esteemed fictitious; and strange to say, often as they have been since described, figured, and said to have been seen by travellers, their most remarkable property, that of emitting light, would seem, even now, a matter of doubt, at all events of disputation.

This appears to have arisen from their luminosity having escaped the notice of various recent observers; but as that of the glowworm and the fire-fly is not always visible, this proves 
nothing. Madame Merian is not, it is true, quite so celebrated for the Dutch accuracy of her pen, as for the fidelity displayed, with few exceptions, by her pencil; but one can hardly suppose that that ingenious and indefatigable lady was deceived herself, or meant to deceive her readers, by mere ignes fatui, in the following often-quoted description of her first acquaintance with the light of the Fulgore:-

"Once," says she, "when the Indians brought me a number of these lantern-carriers, I put them in a wooden box without being aware of their shining at night, but being awakened by an unusual noise (probably their singing), and being much frightened, I jumped out of bed, and ordered a light, not knowing whence the sound proceeded. We soon discovered that its origin was in the box, which we opened with some degree of fear, and were still more alarmed, even to letting it fall, when there appeared to issue from it a flame which seemed to receive additional lustre as often as another insect flew out."

Donovan's minute description and figure of the Red-tipped lantern-fly* of Hindostan, would appear to leave even less room for disbelief as to the lumen of this creature's fiery proboscis, a Bardolphian nose giving it a just title to be regarded, amongst insects, as, verily, a true "Knight of the burning lamp." Our author says of a specimen in his own possession, that "its large, dark purple trunk is sprinkled with spots of

* Fulgore pyrorhynchus. Donovan's 'Insects of India.'

VOL. III. 
white phosphorescent powder, and the tip, which is scarlet, and somewhat pellucid, still retains a reddish glow that almost convinces us that the insect, when living, diffused light from both ;"-that is, trunk and its apex. "Supposing (he adds) this conjecture right, the illuminater apex of the trunk would. resemble a globule of fire, and the numerous phosphoric spots on the tube form a train of glittering stars to accompany it." This truly would be an insect comet.

Our present rapid communication with India, and new relations with China, might soon, we should think, afford opportunities for the dispersion of evcry shade of doubt, if any rcmains, concerning the light-giving properties of these Fulgora. Imported from the above countries in the egg, or eren alive, and hatched or kept living by artificial heat, we may yet see with our own stay-at-home eyes, whether these living lanterns carry light; and if so it prove, might we not, curiously, peruse letters from China, by aid of an insect luminary which may have helped once to light a real pagoda,-have perched upon the towers of Pekin, or even have flown "betwixt the wind" and his Celestial Majesty?

Perhaps, also, amongst other benefits derived, from the ends of the world being brought so near together, may result, during the course of this economic and arlaptive age, the employment of the "Fulgora candelaria," even to the saving of our own candle-ends, and the helping to "make both ends meet."

Yet more desirable, and more easy, doubtless, to accomplish, 
than the introduction, "all alive," of the lantern-carriers,* would be that of the beautiful fire-fliest so abundant in the West Indies and South America. Ocular demonstration is not indeed, in their case, wanted for the purpose of throwing light on the matter of their own effulgence, on which not a shadow of obscurity exists; but since not merely to introduce, but also to naturalize them would seem no Utopian project, it were well worth the trial, for the sake of throwing tropic radiance on our native landscapes. These brilliant foreigners being natives also of Canada and the Vaudois, where the winters are so rigorous, there seems the less reason why they should not be acclimated to Britain.

A gentleman $\ddagger$ attempting to introduce them from the Bahamas, kept them on the voyage, from June to September, feeding them on the juice from sugar-canes, which they broke to obtain. The supplying their cages with damp moss, or their daily immersion in cold water, has been recommended for their preservation, by affording a substitute for the moisture of the damp meadows which are their favourite localities.

The great lantern-flies spoken of above, belong to that order of insects termed Hemiptera, being allied, unlike as they may seem, to bugs, boat-flies, and water-scorpions; but the fire-fly of the tropics, our present subject, being of the order Coleopter a, is a beetle. By day, as sombre and dull..looking a little animal as any to be seen; shape, longish; colour,
* Fulgore.
+ Elaterida.
$\ddagger$ Mr. Lees.

L 2 
blackish brown. When at rest, or walking, it is content with the display of only two lights, emitted from a pair of lamps, or yellow tubercles, placed on either side the chest; but when, with wings extended, it shoots across the dusky sky, another luminary, also in the thorax, but seated further back, is rendered visible.

Though we have none of these fire-flies, as yet, in England, we have certain insects of the same family, which in all, save luminosity, greatly resemble them. These are the very common longish brown beetles, known familiarly as "spring and click beetles," also "skip-jacks"-names expressive of their power, when laid upon their backs, of springing or leaping into the air, with a clicking sound.

Our readers, as we hope, all know by this time, that every beetle has been in its time a grub or larva. They have all heard, too, most likely, of that farmer's terror, the destructive wire-norm; but to some, even amongst farmers, it may possibly be a piece of information that this wire-worm is none other than a beetle grub, and the grub, moreover, of such a bectle as the click, or skip-jack, an Elator,* nearly resembling the tropic fire-fly; the grub of the latter loving to feed on the roots of sugar-canes (to which, says Humboldt, it is often very injurious), in lien of the roots of corn and other vegetables, the favourite fare of his British relative.

These foreign lights (though the last, at all events, are no 
ignes fatui) have lured us, already, somewhat wide of our selfappointed track, the haunts, namely, of our native insects ; but before we return to them, we must yet wander for awhile amidst a brilliant galaxy of "winged stars," the Lampyrida, or flying glowworms of the south of Europe.* These are also the Italian Lucciole, of the which, having, en fabuliste, discoursed already, we are the more beholden to give, en naturaliste, some brief account.

Like the tropic fire-flies, these glowworms are beetles, though of a different family, that of the Lampyrida, of which the Lucciola is a very small species, with blackish-brown wingcases; the legs, as well as thorax, of which the shield nearly hides the head, being reddish yellow. The light of these insects, when creeping, or perching upon trees, is described as being hardly perceptible, but becoming brilliant on flight; not constant, but scintillating, as if disclosed on successive expansions of the wings. Appearing with the twilight, their full radiance shines forth in darkness; when some, shooting through the air, make luminous tracks in all directions, while others spangle the shrubs and herbage. $\dagger$

Their appearance and effect in the neighbourhood of Genoa has been thus described by Sir J. E. Smith : -

"On the eve of St. John the Baptist, the great festival of Genoa, the town was brilliantly illuminated, while along the

* Lampyris Italica.

† See 'Naturalist's Library.'

‡ In 'Sketch of a Tour on the Continent,' quoted in 'Nat. Lib.' 
purple coast to the west, the last rays of the setting sun still trembled on the hills, and the moon arose in the east. To these three contrasted lights was added the singular effect of innumerable flying glowworms darting their momentary splendour through all the streets, gardens, and rooms. We used frequently to catch these little insects, and entangle them in the ladies' hair and hend.dresses, a decoration which the women of some countries adopt for themselves."

By the same writer is mentioned the superstitions of some Moorish ladies (prisoners of the Genoese), who on a sultry summer's evening shut their windows against these luminous visitants, under the idea that they were the souls of departed relatives. A similar notion is said to prevail amongst the Italian peasantry concerning the Lucciola, and is entertained by the ignorant of other countries with respect to luminous insects of their own.

Some of these glowworms of southern Europe* - called flying, because the beetles of both sexes, contrary to those of England, sport wings-have been seen, it is said, in Hertfordshire; and there is little doubt but what these, at all events, might be introduced and established in our southern counties.

Now we are at home again! From the swamps of Guiana and the jungles of India; from the savannahs and plantations of the West Indies; from the olive-groves and vineyards of southern Europe, with their noisy lantern-bearers - their * See 'Le Lucciole. 
effulgent tire-flies-their sparkling lucciole-we are returned to the quiet over-arching lanes of our own England, and the quiet radiance of our English glowworm ; and, after all we have been saying about the importation of foreign stars, perhaps we should be very sorry to see the eclipse of our native gem.

As well, perhaps, might we desire to behold the modest maids and wives of England (of whom glowworms are the slining symbols) eclipsed in their quiet homes by the brilliant charmers of east, and west, and south, dazzling and restless as the luminous flutterers of their respective climes. Each, doubtless, are best in their own accordant places.

Our English glowworm* (as we presume most people are aware) is the wingless female of a winged beetle, which also carries a light, though one of much inferior lustre. $\dagger$ As surrounded by hedge-row flowers (symbols of home attractions), she shines from her mossy bed, supposed to guide the eye while awaiting the appearance of her active mate, truly the glowworm is a perfect image of loving maiden or anxious wife, who, at a cottage in the very lane close by, has placed a candle in the casement, or heaped wood upon the hearth, by way, at once, of pole-star and of welcome, to her hastening swain or loitering husband. Pity that an idea so pretty should have come, in these unpoetic days, to be looked on as a mere growth of fancy, nipped, though not uprooted, by the

* Lampyris noctiluca. See Vignette.

$\uparrow$ A solitary glowworm, resembling the English but much larger and more brilliant, was seen by Bishop Heber in Ceylon. He makes no meution of lantern-flies. 
tonch of cold Inquiry. But so it is; and from the-winged lover being provided with a lantern of his own (albeit, a dark one), as well as from other facts, not more conclusive, it has been doubted whether, after all, the torches of Cupid and of Hymen have been the true illuminators of the glowworm's lamp. Cui bono, then, the lady's taper? To answer this inquiry Conjecture has been clever, but, as usual, often at variance with herself.

While it is supposed by some, that the light of the wingless beetle is bestowed for her protection, to scare away her hungry foes, the nightingale and other birds of night; it is opined by others, that the insect's gift of brilliancy (like many of the like sort bestowed upon mankind) is the very mean of her destruction, the very lure and light by which her biped foes are assisted to discover and devour her.

Some people, again, have suggested that, whatsoever else its purpose, the glowworm's luminary may be employed as a lamp for her own supper-table, after laving previously lent its aid in the finding of her evening meal. It has been observed, indeed, that, for the serving of both such uses, her light would have seemed placed more conveniently at head than tail; but its diffusion, we should think, is amply wide enough to render this objection of little import.

The Lampyrida, even of our northern climate, have southern predilections, being never seen in the north of Scotland, and most universally abounding in the southern English countics. 
To most of the dwellers in these her favourite resorts, the person of our insect lamp-bearer, so conspicuously displayed in her own light, must have been, we should suppose, familiar (as with ourselves) from the summer nights of childhood,from that night, in particular, never to be forgot, which first brought one of these shining mysteries within the compass of our fingers and a box. While of other little creepers we yet scarce knew the difference betwixt head and tail, the figure of our first captive glowworm, as seen at night, and examined next morning, almost before daylight served, was stamped upon our memory; and, had we never seen another since, we should not forget her tiny head and, as we called them, horns, mocking our curious eye, as she just put forth and then withdrew them under the shielding back-plate which covered the fore part of her body; that slate-coloured, oblong, flat, wingless body, all divided into rings, and bearing at its nether extremity the lamp,-by night a lustrous emerald, by day a dull pale spot,-composed, as we have learnt now, of the sulphur-coloured substance which supplies its light.*

Of this article, by the way, though it costs her nothing, the glowworm, it would seem, is somewhat economic; Gilbert White, at least, confirmatory of Will Shakspeare, having thought that she always puts out her light at the decent hour of eleven or twelve, or begins then, according to the poet and the poetic idea, to "pale her ineffectual fire." 
Now for a word or two,-borrowed, of course, from the scientific page, but considerably at variance,-respecting the supposed nature and quality of this and other insect fires. One experimentalist,* having found that the glowworm's light is neither diminished by immersion in water, nor increased by application of heat,- - that it is not capable of ignition by the flame of a candle, nor possessed of any sensible heat when separate from the bearer's body, denies in this luminous matter the existence of any ordinary composition of phosphorus; suggesting, howerer, that the above facts are favourable to the supposition of light being a quality of matter, rather than a substance.

Another examiner, $\dagger$ on the contrary, seems to have ascertained that the glowworm's light-diffusing substance is chiefly albumen, combined with a portion of phosphorus; and as phosphorus can only become luminous by contact with oxygen (supposing it uncombined with a fatty matter or albumen), he considers this requisite supplied by means of the male insect's respiration, which is strongest during flight; while, in the female, which flies not at all, the greater quantity of albuminous substance contained in her thick body more than compensates for the lesser respiratory action.

Enough, at all events, has been ascertained about the illuminating matter of the glowworm's lamp to prove it perfectly

* Mr. Macartney, quoted by Kirby and Spence.

† Mr. Macaire, quoted in 'Naturalist's Library.' 
incapable of setting light to any tapers, save those of fairy manufacture. Who could quarrel with that pretty conceit of our immortal Bard, which converts "the glowworm's fiery eyes" into lucifers, for the use of Titania's household? Yet, in our character of entomologist, we may, perhaps, be permitted to observe, that Shakespeare has here taken more of poet's license than he is wont to do in his allusions to natural objects, which are in general so infinitely more correct than those of his modern brethren of the lyre. It is admissible enough to term "fiery" what looks luminous, but it is a long stretch, truly, even to the length of the creature's antipodes, to endow it with "fiery eyes," in lieu of a fiery-seeming tail. Though the eyes of most night-prowlers are luminous, those of the female glowworm are not, we believe, at all so, any more than those of her flying mate ;* but the latter are prodigiously large, so large as to constitute the largest portion of his head. The purpose of these disproportioned organs cannot, perhaps, be positively told; but, according to the old theory of the "light of love," we should suppose that if the lady glowworm (an insect Hero) were, on first acquaintance, to exclaim to her Leander, "Oh, my dear! what great eyes you have!" he would reply, like the wolfish granddam, though in quite another spirit, " $\mathrm{Ah}$, love! they are all the better to see you with!”

Before having quite done with "fiery eyes," we may notice 
that if the "Swan of Avon" had applied this epithet to the moth instead of glowworm, his fancy would have better corresponded with fact; for a fact it is, though probably quite unknown in the days of Shakspeare, that many species of night-flying moths are endowed with luminosity in the organs of sight, the light being most visible while the insect is in motion.

"Pour l'amour de ses beaux yeux," we may perhaps, therefore, include the moth among luminous insects; but there is another, a native of England, perhaps as common as the glowworm, which, although from its habits comparatively little noticed, shares her luminous endowments to a very considerable extent. This is the electric centipede,* a black, many-legged crawler, which almost everybody must have seen and shrunk from, as it has crossed their path in the daytime. As this creature (which has been likened to a miniature model of a serpent's skeleton) mores, serpent-like, forward or backward, he leaves behind him, or before him, a tangible track of the phosphoric light, which, in darkness, strongly illuminates his unsightly form; but, as if conscious of his loathly aspect, it is mostly in daylight, when it is least conspicuous, that he issues from his lair, some abode of darkness, either in the earth, or beneath a stone.

The Mole Cricket is another insect which has been supposed to emit light; to have been, indeed, in some cases, the

* Scolopendra electrica. Sce Vignettc. 
veritable Jack o' Lantern-the ignis fatuus of the benighted traveller. But of this curious insect we have already narrated facts and told a tale.

The harmless quality of all these insect lights is a kind provision of nature, no less adapted than a variety of others to attract our admiring notice.

Truly, it is a thing wonderful and beautiful, to find in animated forms a substance so nearly resembling that formidable element, fire ; one possessed of its power to diffuse light, yet wholly destitute of its dangerous properties. Had it been otherwise, only imagine the direful results. Earth would have been the scene of perpetual conflagrations, and its inhabitants for ever on the watch to extinguish or guard against the mischief of living sparks. A few tribes of fiery insects would have sufficed to change the entire face of nature and the superstructures of man.

Where, in America, would have been the forests? Consumed, perhaps, before worthy of the name, or cleared by the fire-fly, before the settler's axe. And where the settler himself, with his log-habitation?

In Asia, wooden temples and pagodas might not have been; or scarce one would have escaped destruction, lit up almost as often by the lantern-fly without, as by the paper lanterns within; while in Europe, even in our native isle, barns would have blazed, and corn and hay-stacks have been nightly fired, and the lurking incendiaries, which no police could have 
detected, no jury have tried, no judge have sentenced, would have been glowworms in the grass, or centipedes in the earth, laying (Fawkes-like) their trains of combustion underground!

But have luminous insects the positive quality of use, as well as the negative attribute of being harmless? In common with all created things undoubtedly they have, and to themselves their luminaries serve clearly some important purpose, however we may yet be in the dark as to their exact mode of appliance. Nor, as regards mankind, are these "diamonds of the night" altogether without their value, having, as such, been made in several countries subservient both to ornament and use.

While our native glowworms have begemmed no other beauty but that of the sleeping wild-flowers, the tropic fireflies have sparkled in dark tresses, and been rivalled by flashing eyes,-have been employed by the gay in the decoration of festive garments, and by the grave in the conning of small print. The Père du Tertre, in his history of the Antilles, speaks of reading his Breviary by the light of one of these living lamps. The natives of St. Domingo, and other islands, are also said to have used them literally as " a light to their feet and a lantern to their paths," by attaching one to each foot when travelling by night, employing them also in the lighting of their habitations. Fire-flies serve, besides, the important purpose of destroying mosquitos, which are their favourite prey. 
But the glimmer of our English glowworm?-that surely can serve no other uses save its own? She would be a dull diamond in the maiden's tresses - a dim light to read by-a sorry lantern on a murky night. True; but for all that, she shines not for herself alone: for us, also, her light is not without its uses. What these are, we may best answer when returning from our summer's evening walk, as the glowworms and the stars are coming out together; for then our minds must be more creeping than the wingless light-bearers themselves, if they rise not from them to the glorious orbs they humbly imitate, and thence to the Great Source and Centre of Life and Light, from whom alike emanate the "stars of the earth" and the suns of the universe.

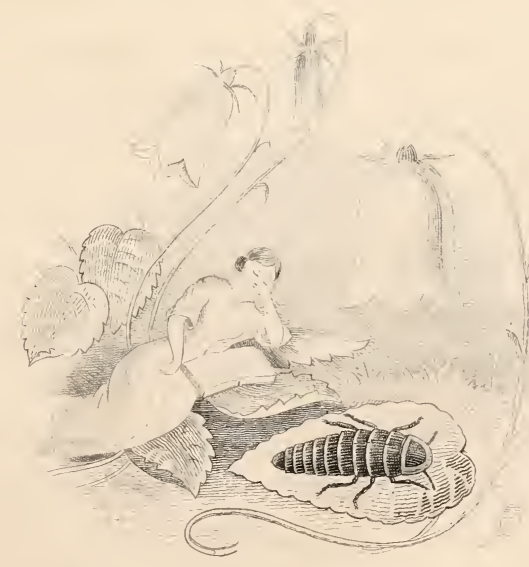




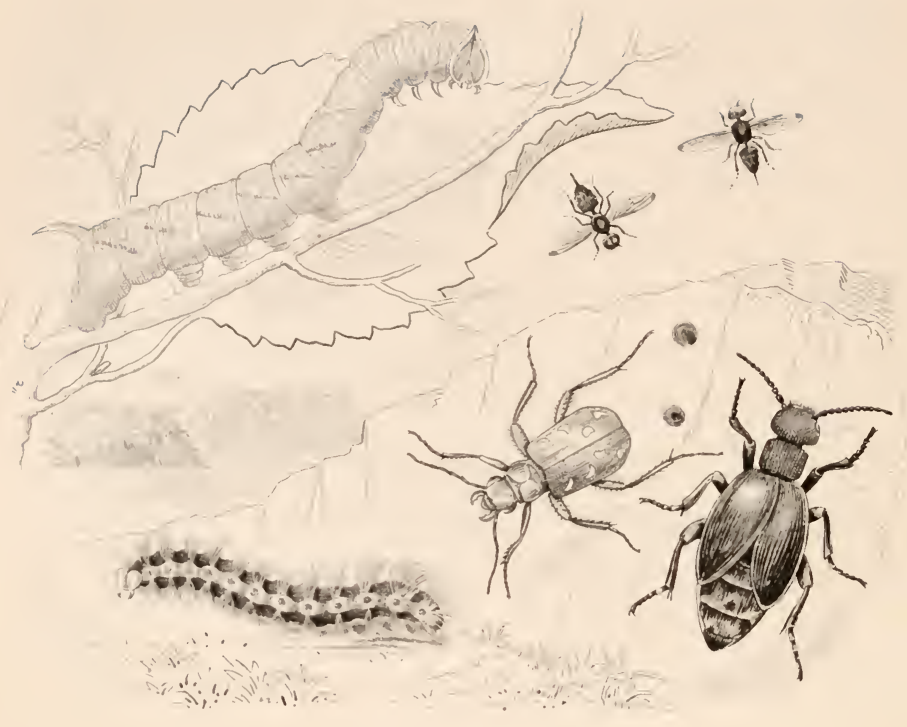

INSECT MOYLMENTS.

"A thousand ways,

L pward and downward, thwarting and convolved, The quivering nations sport."

Ir their endless variety of movement, the Insect races resemble, equal, and in many cases surpass, nearly every other :mimated tribe of earth, air, and water. They walk, with the quadruped; fly, with the bird; crawl, with the reptile; swim, with the fish; do all, in short, but march erect, like the man and the monkey; while many of them are endowed with motive 
powers of a kind possessed by no other living creatures with which we are acquainted.

But the best way, perhaps, to obtain a tolerable notion of the extent and perfection of insect activities, will be to divide them into two classes, the one consisting of movements common to other animals, the other of those nearly or quite peculiar to themselves.

First, for that most ordinary mode of progression, walking. This, among insects, (most of which are possessed, in their perfect state, of six legs) varies in rate or pace from the slowest creep to the swiftest run. The Coleoptera, or Bectletribe, alone furnish instances of each degree of progression exemplified in its extremes by the laborious creep of the oilbeetle,* overwhelmed, seemingly, by oozing fatness, and the light, rapid, agile course of the predatory Carabus, ${ }^{*}$ or that of the rapacious Cicindela, resembling

"The forest's leaping panther,

Fierce, beautiful, and fleet."

Some butterflies-amongst others, the little "Tortoise-shell" -may be designated insect quadrupeds, inasmuch as of their six legs the two foremost being very short and imperfect, four only serve the purpose of walking; an accomplishment, by the way, in which butterflies in general, like the ladies of England, do not particularly excel. If rapidity of pace depended on the number of instruments employed in walking, both butterfly 
and moth, in their estate of caterpillar, would always outstrip, as pedestrians, their own winged maturity, sixteen, instead of six or four, being the number of legs with which caterpillars are usually provided. This, however, is only the case in certain instances, for hardly do beetles exhibit greater variety in their rates of movement than the larvæ of Lepidoptera. We speak, indeed, of all caterpillars as "crawlers;" but while some "drag their slow length along," tardy as the tortoise, or that

"Enfant de la terre errant sur le gazon,

Privé d'os et de sang, et portant sa maison,"

others run with the rapidity of "the Hare," an appellative really bestowed for its swiftness, on a foreign species. There are not wanting English runuers of the same description. We may notice, amongst them, as a very common specimen, a caterpillar (that, we believe, of the large Ermine Moth) with a skin blackish or greenish, striated in its length by a broad white line on either side, and thickly covered by a coat of long brown fur, made up of tufts proceeding from studs or tubercles.* This, one of the pillagers of promiscuous cates of an herbaceous description, may frequently be seen by roadside or in garden, and usually in company of several messmates, employing his jaws with prodigious celerity on the leaves of dock, plantain, dandelion, marigold, or violet. If we rudely interrupt him in his harmless feasting, he rolls up instanter, and falls from his station-a defensive feint of death or inactivity, 
from which, presently, he betakes himself to flight, and runs, or more properly glides, away with a degree of celerity which leaves no doubt of the excellent use he can make, on occasion, of his eight pair of heels.

The "Tiger," elsewhere spoken of, which, in clothing and feeding and rolling, greatly resembles the above, is, like him, swift of foot, even when attained to the weighty bulk of his mature growth.

As one of the foremost-hindmost, rather-of the creeping caterpillars, has been noticed that of the Hawk-moth Filipendula; and the majority of its Sphinx-like brethren* are slow footed as well as averse to movement.

Caterpillars have other uses for their legs besides that of locomotion, and every one of them is furnished with two sets of feet differently constructed, and adapted to different purposes. Of these, the six foremost are clawed, and are therefore handily convenient for holding and managing the leaves used for food or habitation, or the threads employed in weaving and suspension. The ten hinder, called prolegs, consist of round fleshy protuberances, fringed with minute hooks, which render them most excellent holdfasts against the shocks of wind and weather by which, but for such grappling instruments, our "spinning worms" would be continually exposed to sudden dislodgment from their high "green workshops."

Flies, wasps, and ichneumons, may be all considered run* See Vignette. 
ners; but, in accordance with that system of compensation so generally carried out amongst created things, it is chiefly amongst insects that are destitute of wings (those comprised in the Linnæan order Aptera) that we meet with such as are most agile and dexterous in the use of their legs, which vary in number from eight to above a hundred.

These creatures with many feet,-including spiders, mites, and scorpions, with eight; wood-lice, with fourteen; centipedes and millipedes, with a hundred and above,-can, most of them, move backwards and forwards, sideways, and in every dircetion, with the most marvellous adroitness and rapidity, though it sometimes better suits the purpose of the wily spider to make his subtle advances almost imperceptibly. There is a little mite, of a pale red with a black dot on the back, a frequenter of strawberry-beds, which has been described as " rather gliding" or flying than using its leg's," its minuteness, as observed by Rennie, adding to the surprise produced by its morements, "for it is little larger than a grain of sand; and though the clods of garden-mould are mountains in comparison to its size, it gallops over them at a thousand times greater proportionate speed than the swiftest race-horse."*

Until able to jump three times as high as St. Paul's, or to vault a quarter of a mile, man must yield the palm of leaping to the flea, the locust, and frog-hopper, which, relatively to their size, have been calculated to do the like, and before 
whose saltatory feats those of man, monkey, hunting-steed, squirrel, and frog itself, sink, therefore, into very tame performances.

As climbers, a variety of insects rival the squirrel; while as burrowers, several, but especially the mole-cricket, emulate the mole.

But if insects, their size considered, outstrip the speed of all other animals in traversing the ground, and their agility in bounding from off its surface, much more do they, as fliers, exceed in proportionate swiftness and power the larger winged tribes which travel through the air.

Birds have, indeed, been said to surpass all other creatures in rapidity of motion, as well as in the faculty of its continuance without interruption. The swallow is calculated to fly, at its usual rate, a mile in a minute, yet has even the swallow been beaten in chase of a dragon-fly, which, when pursued in a menagerie a hundred feet long, is recorded by Lewenhoek to have baffled and kept in advance of the bird. Nor is it in speed only that the flight of the dragon-fly resembles that of the swallow. The swallow sweeps over the meadows on a summer's evening in lightning-like zigzags, and the dragon-fly is endowed with the power of cleaving the air in all directions —right and left, forwards and backwards-without turning. The swallow is said to keep up its race-horse speed for ten hours on a stretch ; and most species of the dragon-fly can, in like manner, remain on wing for hours when hawking about, 
like the swallow, in pursuit of insect prey. This untiring power of flight is attributable, in the insect, to the numerous nervures by which the four large wings of the Neuroptera are so beautifully reticulated.

The skylark, in its morning ascension to "Heaven's gate," is followed in flight, if not in harmony, by that regal butterfly the "Purple Emperor," which, from his lofty throne upon the oak, can mount with the ascending sun to a height invisible, thence descending with the glorious orb of day.

In the power of stationary suspension, or hovering in the air, the hawk-tribe has also its insect representative in that of the Sphinxes or Hawk-moths, which are accustomed, as elscwhere noticed, to hang suspended on quivering wing, whilc, with their long tongues unfolded, they rifle, like the hummingbird, the sweets of their favourite flowers.

Besides the above, which are seldom abroad except at evening or at early morn, there are to be seen throughout the summer and the livelong summer's day, hovering over flower-borders or flowery liedges, a scattered company of twowinged flies which, as somewhat resembling, may be taken on a cursory view for four-winged bees. These are the Syrphii, whose prowess, while in their grub estate, as clearers of aphis-covered leaves-those especially of the rose-treewe have celebrated in another place.* Contributing thus, through the carnivorous appetite of their growing youth, to

\footnotetext{
* See article on Aphides, and Vignette.
} 
the health and preservation of the plant, these aphidivorous flies, in their active and elegant maturity, heighten the beauty of the flower by adding to the number of its prettiest frequenters, as they now hover over the enamelled beds in suspension, seeming motionless, but maintained, in reality, by fast vibration of their pinions-then dart with rapidity to some other wing-poised station.

Few, perhaps, to look at the great burly body of a humble bee when he is "tippling freely in a flower," would suspect him of out-cutting, when on wing, all the other ligh-fliers, and swift-fliers, and far-fliers of his order (Hymenoptera), including, as it does, all other bees, wasps, ichneumons, and saw-flies. Yet such is his reputation in the field (of air), or in the sporting calendar of the naturalist; and while it outstrips its kind, the humble-bee (by no means humble in this particular) far exceeds, says Kirby, in proportion to its size, the flight of any bird.

It is said by a German naturalist,* in speaking of the emigrations of the feathered race, that birds require a wind which blows against them, such a contrary current helping to raise, and assist their flight. We are not aware, indeed, of any insect known to require this seemingly hindering help; but, however little one might think it, the comparatively fragile wings even of insects are often arrayed in battle against an opposing current. 
Not only can bees and some beetles pursue their flight in the wind's eye, but even butterflies have been seen, with their "sail-broad vans," making way against it. In power, swiftness, and grace of motion "the painted populace" present, in different fanilies, something of the variety which adorns their pinions; but when we look at these summer vagrants, idly flitting

"From bed to bed, from one to t'other border,"

we should hardly expect them ever to exemplify permanence as well as power of flight. We hear, however, not only of migrating birds, but also of migrating butterflies, of which some, not satisfied

"The woods, the rivers, and the meadows green,

With their aire-eutting wings to measure wide,"

attempt, occasionally, to " measure ocean." For this purpose they sometimes assemble in gaily-bannered companies, and, in a straightforward continued course, press seaward and orer sea, only, probably, to add in most cases to the number of those fair and fragile things which, strewed upon its surface, are for ever serving to augment the perishable "treasures of the deep."

But we need not follow insects over ocean, or cren stir from off our chair, to see the surpassing power of their organs of flight; or, if we do not now see, we may remember, that the fly, now crawling so feebly up our window, was able, in the sunny heyday of her vigour, to sport above our heads at the rate of abore thirty feet in a second, or more than the third of 
a mile in a minute-the third of the distance which a racehorse can achieve in the same period.

When, from the air, we glance downwards to the waters, we find the finny tribes in like manner equalled and, size considered, exceeded in their motive powers by a variety of insect swimmers. Those which, in their perfect state, are wont to inhabit or frequently resort to ponds and ditches-such, for instance, as aquatic beetles-are usually provided with a pair of hinder legs, long, strong, rather flattened, and densely fringed with hair, assisted by which they cut the fluid element in all directions, darting about, rising to the surface, or diving to the bottom with the utmost rapidity.

The above are among the principal of those insect movements which resemble the common motions, on land, in air, and in water, of other animals ; but the latter exhibit some of a more peculiar character, wherewith insects also are endowed, besides others which would seem common to no other creatures but themselves.

The serpent, deriving a false consequence from its very sentence of degradation, is said to have partly owed its deification to the power, once looked on as miraculous, of crawling without legs. This attribute of once mysterious motion is shared by many insects, which in their state of larva are legless, but can glide onwards, and sometimes with rapidity, not pushed along like the serpent by the points of its ribs, but by alternate contraction and extension of the rings of the body. 
The wonderful leaps of the salmon up cataracts (which these alone enable it to ascend), if, as has been stated, performed with tail in mouth, are imitated in manner as well as magnitude by an insect leaper, of which, as of the salmon, it may be descriptively affirmed that it is "at once both bow and arrow." This little animal, which is the legless larva of a tuinute and pretty fly, and not, as is popularly supposed, a mere offspring of decay, is none other than the cheese-hopper, a very curious and admirably-constructed creature, though to none, save to entomologists and certain epicures, an object of admiration. Swammerdam saw one of these legless leapers spring out of a box six inches deep, or twenty-four times the length of its own body. To compass leaps like this and others more stupendous, the saltatory performer erects itself on its tail, which is furnished with two projections that enable it to maintain its balance. It then bends itself into a circle, catches a part near the tail with its looked jaws, and, after strongly contracting itself from a circle into an oval, throws itself with a jerk into a straight line; an action which effects the leap.

There is a certain fish,* which, when tired of swimming in its native element, is said to take the air by ascending trees. This climbing fish must be looked on, we should think, as a very odd fish among his finny fellows, on account of the strangeness of such proceeding, but the oddest part of it, to us, must appear, while unexplained, the power of the legless

* Perca scandens. - Note in Sharon Turner's 'Sacred History of the World.' 
swimmer to accomplish his restless or ambitious purpose. This is effected, it would seem, by help of his spiny fins and gillcovers.

Now a climbing chrysalis, as all must be ready to admit who know a chrysalis by sight, is a thing of scarcely less wondrous seeming than a climbing fish; and we find, in some instances, that the apparatus by which a chrysalis is assisted to climb, or raise itself upwards towards the surface, or from out the ground or other imbedding substance, is of a somewhat similar description to the spines of the above-mentioned tenant of the waters. To give an instance.-

The Goat-moth, whose works, as a carpenter caterpillar, in heart of oak or willow we have elsewhere noticed, has a chrysalis which, as well as some others, is furnished with a row of spiny serratures, extending nearly round each ring of its body. The use of these appendages becomes sufficiently apparent when opportunity offers (as it has done with ourselves) of watching the emergement of this case-bound creature from out the strong cell of cemented woody particles in which it is usually enclosed. A hard head, armed with points, having first enabled it to open, as with a battering-ram, a breach in the wooden walls of its prison, the swathed moth is then assisted by the purchase of its spiny case to draw itself more than half-way through the opening, wherein it remains tightly wedged, while the aurelian skin, bursting at the shoulders, gives egress to the winged form. 
The chewing of the cud by the cow, and the washing of her face by the cat, are motions to which others employed at certain times by certain insects have been compared. One can hardly, indeed, take notice of a fly in her frequent occupation, that of stroking over her head and eyes with her fore feet as she basks in a sunny window, without being reminded of Puss washing over her ears as she blinks at the fire; and it would seem that the quadruped and the hexapod perform these similar actions for a similar purpose, with a view, namely, to personal propreté, a virtue wherein insects particularly excel. Again, there is a certain movement exhibited by the grasshopper and his kind-a continual champing of the jaws when there is nothing edible between them,-which a common, at least a cursory observer, is not very likely to discern; but if he did, it is not improbable that he might be led thereby, as was once a celebrated naturalist,* to assign to the grasshopper a place among the ruminating animals; whereas this mumbling of the leaping, long-eared grazer, the stroking of the domestic fly, and other somewhat similar performances in other insects, have been attributed, on seemingly better grounds, to the same originating cause-the desire, namely, on the part of the performer to rid its feet, or flexible antennæ, of every particle of dust or other defilement.

While speaking of insect movements which have their seeming parallels among the larger animals, we may notice the 
proceeding (to us a strange one) of three several caterpillars of the "Lime Hawk,"* which we had in feeding last summer. Just before these entered for transformation their provided bed of earth, and after their hue of brilliant green had faded to a sickly brown, they commenced, to all appearance, licking their bodies all over from neck to tail, reminding one of a dog or cat when similarly employed. This operation could hardly have been for the mere cleaning of a skin so speedily to be cast off. Could it have been intended to render it more pliant and easy to detach?

We once supposed that amphibious reptiles were the only creatures sharing with aquatic insects the power of walking under the element they frequent; but are informed by Rennie, $\uparrow$ that in such performance they are matched by the water ousel, which he has "seen repeatedly walk deliberately under water (in pursuit of insects and small fry of fish), and continue its pace for many yards, as if on land." This, an unusual, if not a singular practice amongst aquatic birds, is a very common one amongst insects of the same description, such as water-beetles, water-scorpions, and water-mites. The latter are pretty little animals, of which some that are scarletcoated cut almost as showy a figure at the bottom of shallow pools and ditches as a larger species, of the like brilliant exterior, one of the heralds of summer, when seen marching upon land.

* See Vignette.

† In 'Insect Trausformations.' 
Many other instances might be cited, both of common and of remarkable movements, wherein insects do the like, while they often do more than other animals. The above, however, show sufficiently that the mechanisms of motion assigned to some of the smallest of living forms are by no means inferior to those bestorred on the largest, while we see in their mutual resemblance an impress stamped on both, of their being the work of one creative hand and mind.

Having then observed, in these similitudes between what we consider among the highest, and what we are apt to look on as among the lowest of the animated races, a very striking exhibition of that unity of design apparent throughout the works of nature, let us notice now a few of those peculiarities (in respect of motion) which belong, or are supposed to belong, to insects only, and admire in these the variety, the exhaustless resources of contrivance and adaptation, which mark the infinitude of the One Creator.

First, as walkers, there are some insects which deviate remarkably from other creatures. The retrograde movements of most animals are of an artificial character, and seem more or less uncasily performed; whereas, in insects of nearly every description, those especially which are wingless, to move in all directions would seem as easy as to progress in one. Those pretty little active flies, with two fringed and sometimes spotted wings, best known as Midges,* such common fre- 
quenters of our windows in early spring, and again towards autumn, usually move in an oblique direction; and in the celebrated grub of the ant-lion we are furnished with an instance of a tardy mover with whom to walk backwards is the only mode of travelling.

Who would expect to find anywhere, save in the thinlypeopled world of monsters, a creature with legs upon its back? Yet have two such been discovered in the world of insects : one, the bat-louse, ${ }^{*}$ which is described as being able to transport itself with marvellous celerity from one end to the other of the furry forest wherein it dwells; the other, the grub of a little gall-fly, $\dagger$ which inhabits one of the berry-shaped galls common upon oak-leaves. The latter can have, of course, but little room for exercise; but Réaumur, its discoverer, can hardly be mistaken in supposing that the singular position of its legs, in the centre of the back, is that of all others best adapted to its hollow sphere of action.

Some insects, again, are not only remarkable for the number of their legs, but also for the remarkable way in which they use them.

"When centipedes walk backwards, they only use their four hind legs, and these, when they walk in the usual way, are not employed, but dragged after them, like the locked wheel of a coach in driving down a hill. It was first observed, we believe, by Kirby, that a millipede, common under stones, the 
bark of trees, and the hollow stems of decaying plants, and provincially termed 'Maggy Manyfeet,' performs its serpentlike motion by extending alternate portions of its numerous legs beyond the line of the body, while those in the intervals preserve a vertical direction."*

The walking of those ten-footed caterpillars called 'Loopers,' or 'Geometers,' is another peculiar mode of progression, $\dagger$ wherein the steps consist, as is imported by their name, of a series of loopings, at each of which, head and tail meeting, the body is arched into the form of a Greek $\Omega$.

The fly's walk against gravity, that phenomenon by common observers so little noted, by careful ones so contradictorily explained, and imitated only by some others of the insect race, is sufficient of itself to confer upon that race a remarkable superiority over all others as walking animals.

Where, above all, shall we find walkers upon water? Nowhere, save in the ponds and pools and ditches and rivulets, whereon, almost daily from spring to autumn, we may see gnats and Tipulce lightly skimming, water-bugs gliding with or against the current, whirlwigs describing circles, and all performing their varied evolutions upon liquid plains with far more ease and dexterity than the most accomplished skater, when those plains are rendered solid.

In air, as well as on land and water, various insects exhibit

* 'Insect Transformations.'

$\dagger$ Not entirely confined to insects, as the little fresh-water hydra (a simple polype) mores in a similar manner. 
peculiar movements, as well as those shared with other winged creatures. The sportive dancing of gnats and Tipulidan flies, the sailing of winged ants, the beautiful undulating suspension of the graceful Ephemerce, would appear to have no exact correspondence amongst feathered fliers; while of a character no less sui generis are various wing exercises of a non-progressive character performed by insects only. Of this latter description is the flirting by the butterfly of her painted fans, the fanning of bees, and the quivering of his little transparent, black-tipped pinions by the "vibrating fly,"* a tiny, scarletheaded, black-bodied lover of the sunshine and of flowers.

The purposes of the above and resembling actions may still, perhaps, admit of doubt, inasmuch as they have been assigned by careful and intelligent observers to different exciting motives. By some, the butterfly has been supposed to flirt her wings simply with the same cooling intent as that wherewith a lady flirts her fan, while another considers that the "Vanessa," when she fans the air with her pinions, is inviting its entrance into their tubes and nervures, as a preparative for flight; and while, by one, the quiverings of the vibrating fly are supposed to assist its respiration, another, from having noticed these same vibrations to be performed only in the sunshine, regards them as expressions merely of delight.

How can we so often permit our minds to stagnate for want of exercise, when even in an insect movement, and the springs

* Scioptera vibrans, Kirby. See Vignette. 
which direct it, there is matter for thought, and doubt, and discovery!

Another peculiarity distinguishes the movements of some insects from those of nearly all other animals save man. This is their power, in some instances, of constructing and availing themselves of what may be called artificial helps. Such are the aerial bridges of silken thread, and the balloons of flake, by which aeronautic spiders cross a void or ascend to the clouds. Such the silken ropes, descending or mounting by whose aid a variety of caterpillars, especially the Loopers, are enabled to break their falls from, or resume their positions upon, elevated stations; and also of this description are the rope-ladders, spun of the same material and employed by the devouring crawler of the cabbage to scale a garden wall, or, if we please to test her ingenuity at efforts for escape, the smooth perpendicular of an imprisoning glass.

The above, and all other insect movements, are, of course, to be observed at various times and seasons; but the subject of animal motion harmonizes not amiss with this present month of November, as well as with the two which have gone before it, for to all three appertain strong and strongly-working features of external movement preceding and preparatory to the external fixedness of winter.

In September, the winds, usually hushed in August, uplift their uproarious voices in the equinoctial gales. The birds, lately so mute, resume their music to lament the departure, as, 
in spring, they had hailed, with joyous carols, the approach of summer.

With October the stir and bustle increases. Summer birds depart, winter ones arrive, and, as leaves fall faster and faster, numberless insects, deprived of their fugacious protection, hasten to betake themselves to more abiding shelter. The beetle-tribe especially are busy in search of such convenicnt retreats as stones, or holes in walls, or crevices in bark afford them, while flies and a few winter-during butterflies resort to close quarters in the ivy.

Throughout October, the face of nature is ustally sumny and joyous, as well as active; yet is there a something in all its stir and bustle like the busy preparations of dear friends about to leave us on a long absence; and as now, in November, these autumnal activities are drawing to a close, the dull sense of parting presses on our spirits with the falling year.

Thus, at least, it sometimes should and must be, where the heart is open to the impressions and the ear awake to the voices of the seasons, which are all of them appointed preachers -Autumn the most emphatic of the four. But what the efficacy of their moral missions, if in arousing thought they arouse not to action also?

Hardly, indeed, can one take note of the preparatory movements of so many divinely-guided creatures in their pursuit, now, of asylums for the coming winter, without being led to ask ourselves, if we, the children of reason, are as wise in our 
generation as these, the children of instinct, and whether it be not time with each of us to begin our preparations for that winter which, on earth, is followed by no spring.

And from our late cursory review of insect movements there also suggests itself, without straining at a moral, a something of individual application in the inquiry as to which among them may represent most aptly our mode of progress or position.

Are we like the giddy whirlwig, idly gyrating in the sun of pleasure? or, as quaintly expressed by a courtly moralist,* sick, at least for a season, of courtly vanitics, are we "daily following of vain pursuits, and so, lyke to a mill-horse treddinge alwaies in the same steppes, ever as far from a worthy and wise man as the circle from the centre?"

Or, as opposed to the worldly giddy, are we of the worldly cunning, ever on the watch, like the wily ant-lion, to arrest for our own benefit the progress of others, while we ourselves unconsciously walk backwards? If we are pursuing a straightforward path, is it, with the "arrowy flight" of the bee, a course of industry and imnocence, or, with the headlong march or flight of the locust, one of reckless mischief?

" Straight forward goes

The lightning's path; and straight the fearful course

Of cannon-ball. Dircet it flies and rapid,

Shattering that it may reach, and shattering

What it rcaches." 
Is such course ours? or is it that gently winding path which follows the curve of moral beauty? Do we remember that

"The road the human being travels,

That on which blessing comes and goes, doth follow

The river's course, the valley's playful windings,

Curves round the cornfields and the hill of vines,

Honouring the holy bounds of property ?"*

If such our course, and every step be taken in confident but humble reliance on Him who directs alike the movements of myriads of insects and myriads of worlds, and guides (though with no such absolute rule) the movements of mind, we may stumble, but we shall not fall.

Should it even appear that, sharing, in a moral sense, the legendary doom of a certain family of Tracies, $\uparrow$ we have always to encounter the wind in our faces, He who has endowed the frail wing of the butterfly with power to support her against a current of air, and the slender limbs of the diminutive Telia with power to glide against a current of water, will not aflord less help to us in battling the adverse elements of life.

He who has given to the fly the adınirable gift of walking against gravity has provided us with fitting aids for the ascension of steeps and acclivities so slippery and perpendicular as

* Coleridge.

$\dagger$ Deseendants of one of the knights who killed Thomas à Becket, upon whom, for the crime of their ancestor, this miraculous penance was said to have been imposed, whether going by land or water.-Fuller. 
to offer, seemingly, no footing for our steps. $\Lambda$ nd, however lowly our position, however often we may have struggled vainly to get onwards, and have sickened with hopelessness at want of means, let us look at the upward movements of the legless, wingless chrysalis, and find therein a symbol of encouragement. Or let us contrast the wondrous leaps of an insect grub, destitute, to all appearance, of every requisite for active motion, with the dormant inactivity of certain butterflies and moths, which, possessing ample wings, never use, seem scarcely conscious of possessing them, and we shall herein read, in emblematic language, that it is not to external appliances, but to inward energy, power, and will (used always with reference to their Almighty Giver), that we ore most chiefly our progress and our place.

We often see such obvious marks of Divine guidance in the movements of animals, that there are times (times of trial, and doubt, and despondency) when one could almost envy the lowest among them for their entire and necessary dependence on their Fatherly Creator. Passing after a tempestuous night through an avenue of lofty elms, we may notice on their rugged trunks a multitude of caterpillars* progressing slowly upwards, in order to regain the leafy pastures from which the wind has shaken them. What, when thrown upon the ground, free, seemingly, to wander in any direction, has thus impelled them to converge, with one accord, towards their native tree, and

\footnotetext{
* Those of the Elm Saw-fly are often thus seen.
} 
remount its toilsome perpendicular? What but the unerring instinct which points out to them the only path towards recovery of their green elysium?

We, perhaps, have been hurled from some elevation as proud, and plentiful, and happy. A way may exist of regaining our lost position, a way there certainly is for the attainment of one far more exalted. But what shall lead us up the difficult ascent? Seems not the worm to possess a better guide than we? It would, assuredly, if it were not our privilege to invoke the aid of Reason's Source and Instinct's Giver, who will lead us surely, not perhaps to the recovery of our transitory Eden, but to the peaceful paradise where storms never rise, where movements never clash, and where every step is a step of progression without hindrance and without end.

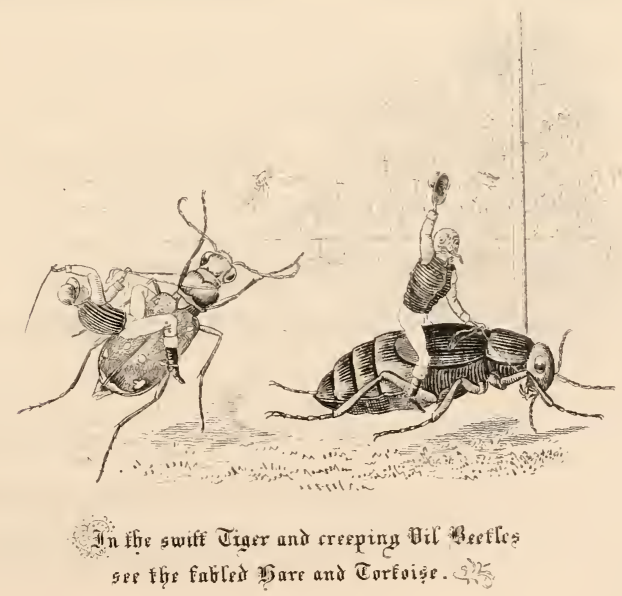




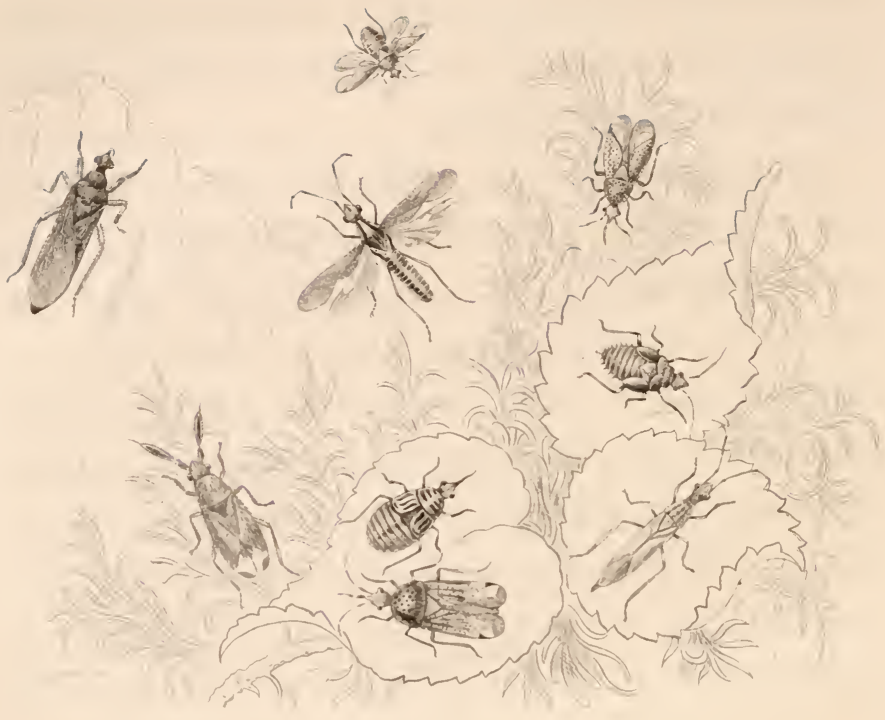

FOR THOSE WHO ARE NOT OVER-NICE.

"With ho! such bugs and goblins in my life."

Now that insects abroad are become comparatively few, it may be as well to notice several of the race which are much too intimately connected with home to be entirely overlookel, though not certainly the most pleasing objects of contemplation.

We shall try, however, in the treatment of our uninviting subject, to handle it as lightly and as slightly as we can, and reverse in our treatment of it the practice of Flemish painters 
and modellers in wax, when depicting the horrors of a martyrdom, or moulding the yet more repulsive tokens of corruption.

A certain sort of martyrdom and things not very remote from corruption are, indeed, involved in our present topic, which we shall proceed, therefore, to treat, as we have said, in a manner as anti-Dutch as consists with accuracy; employing, to throw over its most ugly features, a softening veil of badinage.

What's coming now? queries a timid or fastidious reader, alarmed at our chapter-head, or preface. Why, only something-certain somethings resembling or allied to certain other somethings of the same description, recorded to have

\section{"Once on a royal plate dropped down."}

Now your inquiry is answered, if you have ever read the courtly epic of our courtly Pindar.

To begin with the beginning - the origin of insect vermin. There is given by a certain traveller * the following curious tradition, as preserved amongst a sect of Kurds who dwelt at the foot of Mount Sindshar.-

"When Noalı's ark sprang a leak by striking against a rock in the vicinity of Mount Sindshar, and Noah despaired altogether of safety, the serpent promised to help him out of his mishap, if he would engage to feed him upon human flesh after the Deluge had subsided. Noah pledged himself to do so ; and the serpent, coiling himself up, drove his body into

* Eulia, quoted in the 'Mirror.' 
the fracture and stopped the leak. When the pluvious element was appeased, and all were making their way out of the ark, the serpent insisted upon the fulfilment of the pledge he had received; but Noah, by Gabriel's advice, committed the serpent to the flames, and, scattering its ashes in the air, there arose out of them flies, fleas, lice, bugs, and all such sorts of vermin as prey upon human blood; and in this manner was Noal's pledge redeemed." **

If this legendary tale were "gospel," what a debt of gratitude, for nothing short of the boon of existence, should we, though for ever paying, still owe, to the serpent progenitor of our insect annoyers! and to these, the offspring of his ashes, well might we spare, without a murmur, the Shylockian tribute exacted for the service of their parent. Then might we read, no longer with contempt and wonder, how that, anong other singular objects of charity in the Banyan hospital of Surat, those rightful claimants, the blood-suckers of mankind, have a ward appropriated for their reception. Then, indeed, admiring the grateful principle of that castern foundation for defrauded and persecuted insect creditors, we should only say of its supporters, What pity that so refincd a sense of justice, such a precious quintessence of charity as theirs, should yet lack one thing-should be adulterated by the payment of their vermin pensioners entirely through other and meaner sources than

* There is also a Ifindu tradition, in which the serpent, instead of saviny, is represented as trying to wreck the Ark. 
their own circulating fluid! The directors of this hospital are said to contract with beggars to supply the objects of their bounty; and herein is the something wanting, whether the establishment be founded on an extreme of humanity or an extreme of justice. Rich votaries of Bramah! to make your charity complete, you should assuage the cravings of your pensioners from the current of your own overflowing veins, and not from the poor exhausted reservoirs of the meagre starveling. Alas! for human nature! So in thy every virtue, carried to a height extreme, may we detect a flaw, even as in the over-stretched mantle of Brahmin charity!

According to the above tradition, human flesh alone would have been heir to the debt for which, in his dire extremity, the venerable Noah was induced to give a bond; but as all beasts, birds, and creeping things, were sharers in the preservation wrought by the cumning stopper of their leaky vessel, it is but fair that they also should pay a part of the tribute prospectively exacted. At all events, we find that throughout each order of animated being, from man down to the meanest insect, there is scarcely one exempt from some tormenting infestor which lives upon its vital juices. Scarce anybody who has ever noticed at all either a common black beetle or a humble-bee, can have failed to observe the shining mail of the one and the downy doublet of the other covered with a living load of small white or brownish insects, from whose attacks they are sometimes brought to a deplorable condition. These 
are mites, or Acari, attached especially to bees and bectles; but butterflies, crickets, ants, and even the formidable dragonfly, are all subject to the attacks of allied species, independent of other life-consuming enemies.

Those little maudites lêtes, termed, facetiously, by a popular author, "game from the capital pastures," find a favourite cuver and preserve amongst the feathers of the bird creation, which, in its numerous varieties, is a prey to insect infestors of this description almost as varied.

'The peacock, strutting in lis grorgeous panoply of plumes, liks, in common with others who are fretting daily under "splendid misery," a "thorn in the flesh," such as the most of his admirers little reck of, in the shape of a tormentor peculiar to himself (the peacock louse*), peculiar also for its own very remarkable exterior.

Poll Parrot or Mistress Cockatoo, when bending her head to invite our caressing fingers, las, ten to one, a less refined motive in the act than a mere love of notice. Even our little pet canary cannot always boast exemption from the "rufllers" of his race. He is sometimes seen to pluck and plume inordinately, without the usual incentive of a cliange of feathers. Now we must not attribute this to mere vanity, nor suppose that he is only smoothing his yellow satin doublet for some imaginary "at home," since it is quite as probable that certain mwelcome visitors, in the form of little red mites, are making 
themselves "at home" in reality under the unwilling shelter of his wing. This, however, with a real pet bird-one, that is to say, kept with cleanliness-is a rare if not unknown occurrence, for the above tormentor of imprisoned warblers is chiefly found in dirty or neglected cages. On this account it needs especial care never to introduce a feathered favourite into an abode which has been pre-occupied, without subjecting it, first, to proper ablution and fumigation.

Ascending to quadrupeds, it is needless to whisper in ears polite the name of that exciting cause, or causes, under which our "Marlboroughs" are apt to forget their high breeding, and our " King Charles's" to encroach on their parlour prerogatives.

Grimalkin, with her own nine lives, has been said by Linnæus to possess a happy immunity from the burthen of carrying other lives about her; but we are more inclined to believe, with less distinguished naturalists, that while Puss is imbibing the yet warm juices of a mouse, a hungry flea may be similarly employed in sucking up her own.

We come now to the insect preyers on lordly man, of whom the lordliest, the kings and potentates of earth, have furnished some striking and most horrible examples of how the meanest and most despicable of earth's denizens have been employed by the Almighty Hand to lower the pride and reprove the cruelty of tyrants and oppressors.

Antiochus Epiphanes, Sylla, the two Hcrods, and the second 
Philip of Spain, the great persecutor of the Protestants, are all recorded to have been frightfully distinguished in their deaths, as in their lives, by falling victims to the pedicular disease. The worm of corruption anticipated in her labours, these livers in luxurious palaces were doomed to bear, hidden beneath their royal purple, devouring myriads of that revolting tribe of insects, whose usual localities and accompaniments are hovels, rags, and wretchedness. Rarely as it may seem to harmonize with the grand scheme of providential dispensation to visit temporal crimes by temporal punishments (except, indeed, by those with which they are almost inseparably linked), one can hardly in the above cases help leaning to the popular belief, that the blood-guiltiness of these royal monsters was in an especial manner visited upon them for warning, if not for retribution.

Various instances are related of another disease, somewhat resembling, though not similar, in which mites, or Acari, lodge beneath the skin. One of these we shall briefly repeat, though often quoted, from Mouffet's 'Theatre of Insects,' because a natural cause is assigned for the infestation there described, such as would scem wanting in the cases of those tormentors tormented, on whom the finger of God was supposed to have been supernaturally laid.

Of " the Lady Penruddocke" our narrator tells us, that Acari, or mites, swarmed in evcry part of her body, head, eyes, nose, lips, gums, and soles of her feet, tormenting her day and 
night, till, in spite of every remedy, all the flesh of her body was consumed, and death relieved lier.

Mouffet supposes that the insects were generated by drinking too copiously of goat's milk; a cause seemingly not improbable, from a species of this insect* being sometimes found in milk.

As connected with kings and rulers, we must advert to the tributary lice of the ancient kings of Mexico and incas of Peru, of whom it has been related, that they found no other means of ridding their subjects of these infestors, save by the animal imposition of a tribute to consist of a certain quantum of the living "specie." Bags full of them were found by Cortez in the palace of Montezuma and in the magazines of King Axajacatil.

Torquemada and other historians assign, however, to this strange poll-tax a motive very different to the above. It was imposed, say they, only on beggars, because Montezuma, who could not suffer idleness in any of his subjects, was determined that even those wretched people who would not labour should be thus employed.

Reader,-have thy midnight slumbers ever been disturbed by ghost or goblin? Unless thou art of the few whose "visionary eyes" have been opened, thou wilt most likely respond in the negative; and yet thou must have been favoured almost above the common lot, if a "fearful shape," whose 
name bears the same alarming import, has never " in dead of night" stalked up and down thy curtains, and with intent far more bloody than ever midnight spectre was known or supposed to entertain. Let us change the question: Have you ever been alarmed, or worse, by that familiar of London, Paris, Madrid, or Lisbon, yclept, in English parlance, a bug? If so, you lave been visited by goblin,-for ghost or goblin does bug, in Celtic, signify. Nor, till in times comparatively recent, has that six-legged "terror," which creepeth by night, been thus appellated.

Of the common root of bug and lugbear a curious proof is noticed in the 'Insect Miscellanies,' namely, that in Matthew's Bible, the fifth verse of the 91st Psalm is rendered"Thou shalt not nede be afraide of any bugs by night;" and in this same sense the word must have been put by Shakespeare into the mouth of the Prince of Denmark:

"With ho! such bugs and goblins in my life."

Chinche, or wall-louse, was the name under which bugs mere known before the time of Ray. But what's in a name? Roses, we know, by any other "would smell as sweet," and, reversing the objects and their quality, let's wash our hands of them. But stop! Before we leave their favourite locality, the bed of down which they convert into a bed of nettles, let's sce what is this moving object* on the floor, by the bedside. 
'Tis nothing but a bit of rubbish, a token of the housemaid's negligence, a mingled piece conglomerate of flue, and dust, and feathers, set in motion by the draught from underneath the door. Yet, no; never did wind create such careful motion;-and see! There is a leg-a living leg-and now another, protruded from the cloak of shreds and patches. Never did lame beggar hitch in his gait more piteously. Perhaps 'tis a great wounded spider caught in the remnants of his own snare. But whatever be the cripple, let's uncloak him.

$\mathrm{Ob}$, the rogue!-impostor!-hypocrite! No sooner is he stripped of his disguise of dirt, than he takes to his heels as if the devil was behind him; but he shall not escape us; and now that he is fairly caught, let us carry him before the light for examination. And, truly, a more ill-looking miscreant, and ferocious withal, was never "pulled up" at Bow Street; his eye, especially, has murder in it, and murder, doubtless, was his design. What other could he have when lurking in disguise, like a cowardly assassin, beside a bed? He is selfcondemned, let not the monster live. Yet the monster is but an insect after all; as such, shall we not spare him as beneath our anger?

"No! for on such a dangerous plea,

Immunity we give each flea."

True; but ill-favoured as he is, our prisoner, in relation to ourselves, is innocent; nay, he is more,-he is, to us, a friend and benefactor in disguise; while of our enemy, the bug, 
although of the same kindred, he is also, in disguise, the deadly foe, destroyer, and devourer. It was in cunning pursuit of this, his darling prey, that we found him, under cover of his rubbish canopy, cautiously advancing, that he might spring, unheeded, on his victim; and for this reason, Reduvius personatus, thou masked bug-catcher, we release, and bid thee go and prosper. It is in its first form of larta, that this wily Reduvius, or bug-catching bug, may occasionally be observed engaged as above described in its useful avocation. "The fierce look of this creature is then rendered," says Kirby, "more hateful by its ocelli, or simple eyes, having a pale iris round a dark pupil." Our figure* is that of the perfect insect, which is often to be found on palings in the month of May.

Before we take our leave of the extensive and ill-famed family of bug, we are bound to rescue it from that common species of injustice to which we owe the proverb of "Give a dog an ill name and hang him." For this purpose, leaving the pent-up precincts of the city for sweet fields and flowergardens, we must introduce thee, Reader, to a numerous tribe, which, though bearing the odium of the same ugly patronymic, are by no means ugly creatures. On the contrary, and as if they borrowed variety and elegance of form, as well as brilliancy of colour, from the plants and blossoms they frequent, these plant-bugs are amongst the rery prettiest of our English 
insects. In place of the loathsome wingless platitude of our domestic town torments, their " country cousins" are adorned, for the most part, with exquisitely delicate and iridescent wings, protected, when at rest, by membranous cases, which in various species present almost every variety of gay, as well as sober colouring. In short, with some general features of resemblance, these respective denizens of light and darkness are as much contrasted with each other, as are the darkness and the light themselves.

Throughout the summer plant-bugs abound; certain kinds of them usually frequenting certain plants. Several of similar form, but varied in colour, red, black, green, are almost always to be found upon the southern-wood.* They are common also, the green especially, on umbelliferous flowers; and there is a pretty brown species peculiar to the thistle, with four delicately mottled membranous wings. The form of these little animals varies sometimes from the usual ovate to the linear, and the legs of many are long, as well as slender. These, as well as the antennæ, are mostly ringed at the joints with a darker or lighter colour, and the shape of the latter organs is in some instances very singular, as well as elegant.* Though always vegetable frequenters, these insects are not, at least, always vegetable feeders; their sharp beak-like suckers (something resembling those of aphides) being sometimes employed upon aphides themselves.

* See Vignette. 
In magnitude, as well as brilliancy of colour, the tropic bugs, as well as tropic butterflies, confessedly excel our own; but for the blue bug of China we have one scarcely less beantiful, the blue bug of England,* which flies in the July sunshine, or is found resting upon heath or trees. $\dagger$

There is one distinctive trait of the Bug-family which prevails, we believe, almost as universally amongst its out-door members as in its domestic branch. However the former may appear to the eye as if invested with a portion of the grace and beauty of the plants on which we find them, there is another organ of perception to which it may possibly become evident that they have not, with its elegance, borrowed also the blossom's sweetness. If their frequently sculptured wing-cases were inscribed, like those of some other insects, with legible characters, "Noli me tangere" is the warning motto they should bear.

Now, for a word or two about that sanguinary little monster, the Flea, which, like other sanguinary monsters of a larger growth, has been, perhaps, of all insects the most distinguished.

Stands it not recorded in listory how that an individual flea was once honoured by a cannon-shot from a female royal hand, that of the celebrated Queen Christina? and is not the brass piece of Lilliputian ordnance used on that

* Pentatoma carulea.

+ The flying bugs of Hindostan, resembling our own domestic species in shape, size, and scent, are deseribed by Bishop Heber as coming out in nightly swarms from every bush, eutering the windows and crowding round the candles. 
memorable occasion exhibited in proof thereof, perhaps, to this very day, in the capital of Sweden?

Has not "a company" of fleas, for many years, attracted, by its unrivalled performances, the curious sight-seers of London? Have they not there beheld a flea quadrille danced to the fiddles of a flea orchestra? Have they not laughed at two pulician combatants, sword in hand, adjusting a point of honour? and (oh! the burlesque on human greatness!) have they not there seen a Napoleon mounted on a flea charger?

It would have been much more fitting had the fallen conqueror himself been personated by a flea, fettered in his ambitious leaps, and displayed, a prisoner, for the world to take amusement in his despairing struggles. It appears, indeed, that the flea quite as ill brooks captivity as did the imperial prisoner of St. Helena; for the Italian, Bertolotti, who was the jailor and exhibitor of the London company, records in a 'Memoir' how that they will sometimes obstinately refuse to move in chains, contracting their legs and antennæ in the most impertinent manner possible till their manacles are removed.

The flea, as compared with the generality of insects, is a long-liver, for the Italian above quoted speaks of having kept one for twenty-three months, when it died apparently of age, having grown gradually darker till it became nearly black. In the days of its prime, its herculean task was to track a man of war; as its strength deelined, its task-master lightened 
that stupendous load to ten links of gold chain, and on growing yet weaker, the venerable prisoner was released even from this splendid misery; but then, alas! its leaps, from two humdred times the length of its own body, could not clear an inch, and at last it could scarcely crawl across its prison.

We all owe our consequence to some sort of power; and to the power of its muscles is the flea indebted for the best part of its celebrity. The extraordinary amount of muscular force, as displayed in its stupendous leaps, attracted very early the curious and observant; and Socrates measuring the leap of a flea, figures in the 'Clouds' of the satirical Aristophanes. And, in sooth, our agile little vaulter can take a leap worth measuring, for in reaching to the distance of two hundred times its own length, it is, in proportion to its size, as if a man should leap from three to four hundred yards.

This marvellous power must have first put it into the head of some ingenious person to display both his own mechanic skill and the flea's strength, by turning the latter into a little draught animal, in which capacity it has been proved capable of drawing three hundred and sixty times its own weight. Mouffet, writing in the reign of Elizabeth, mentions an English mechanic named Mark, who constructed a chain of gold as long as his finger, which with lock and key were dragged along by a single flea ; and by a similar piece of vulcanic workmanship did another acquire proverbial repute as 
"The little smith of Nottingham,

Who doth the work that no man can."

In Bingley's 'Animal Biography' are related other the like instances of human ingenuity and insect prowess; and Latreille celebrates the strength and courage of another Samsonian flea, which drew a silver mounted cannon, and stood fire, unmoved, when the piece of loaded artillery was let off.

These and all other such recorded feats have ceased to be marvels to the patrons of those "industrious fleas" who still, we believe, continue to ply their daily labours in Regent Street or the Strand; but they serve to show, that amongst the grand discoveries and inventions of this our 19th century, the art of breaking in fleas to harness is not one. Bertolotti asserts that the saddles, \&c., on his flea company were really fastened by girths, not by gum, as the incredulous have thought, the corslets of the pygmy wearers being too highly polished for anything to stick upon them.

Of fleas there are reckoned at least a dozen species, though some, perhaps, distinguishable only to the eye of an entomologist. Those which infest birds and beasts, and those which honour us with their peculiar preference, are each distinct kinds, and are probably therefore endowed with tastes too discriminating to abide long in, even if they emigrate to, foreign quarters. Comfort herein for the delicately apprehensive, who, having no dogs of their own, are apt to feel fidgety 
and irritable in company of those which belong to their neighbours.

We have spoken at a former page of Hindoo infirmaries for the lower animals, and may notice here that, singular as these establishments may be in their design, they would seem exceedingly like in their aluses to other charitable institutions. In what soil do not tares spring up among the wheat? if even the term "wheat" can be applied with any fitness to the distorted growrths of Brahminical humanity. Of its chaffy quality we may form a tolerable estimate from the following relation of Bishop Heber:- " $\Lambda$ t Broach * is a hospital for sick and infirm beasts, birds, and insects. It is a dirty and neglected place, which, though it has considerable endowments in land, only serves to enrich the Brahmins who manage it. They have not only those animals which the Hindoos account sacred, as monkeys, peacocks, \&c., but horses, dogs, and cats ; they have also, in boxes, an assortment of lice and fleas. It is not true, howerer, that they feed these on the flesh of beggars hired for the purpose. The Brahmins say that insects as well as the other inmates of their infirmary are fed with vegetables only, such as rice, sc. How the insects thrive I did not hear; but the old horses and dogs, nay, the peacocks and apes, are allowed to starve, and the only creatures said to be in any tolerable plight are some milch-cows, which may be kept from other motives than charity." $\dagger$

* A town two or three days' journey from Surat.

† Heber's 'Narrative of a Journey through the Upper Provinces of India.' 
We have thus endeavoured briefly to biographize that redoubtable trio of blood-suckers, louse, bug, and flea,-those insect Eumenides which scourge both prince and peasant. Does either prince or peasant ask, complainingly, Wherefore am I subject to such vile tormentors? To the prince we would reply, When your highness finds a flea upon your purple, it comes to remind you that you are of ordinary flesh and blood, that you are nothing better than a man. To the peasant we would answer, When your lowness finds a flea, or something worse, upon your tatters, it comes to teach you that flesh and blood want soap and water, without which you will soon be nothing better than a brute!

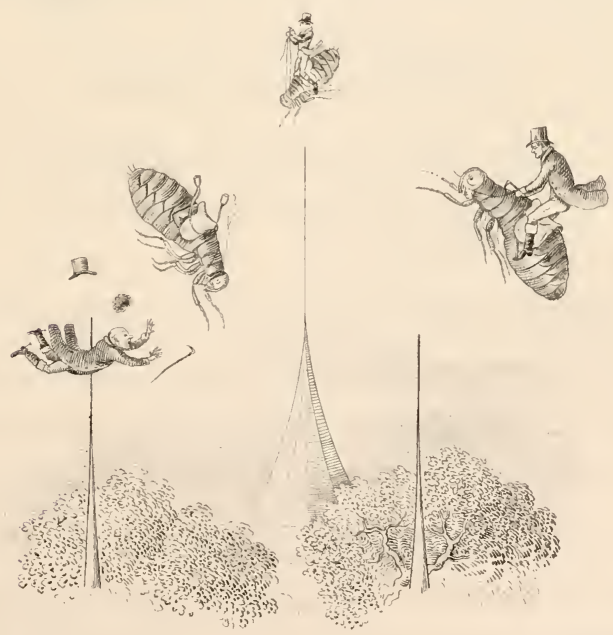

Sffeds of metal ant muscle for a sferple-tiasc in carwest 


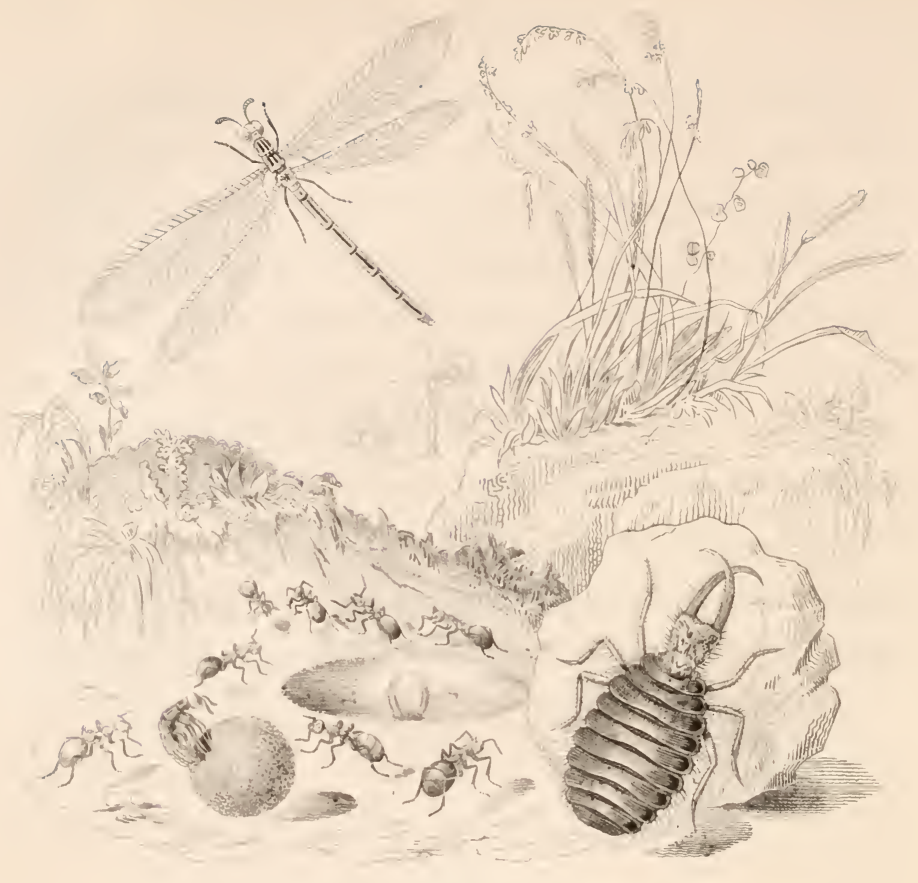

\section{STORY OF AN OGRE.}

"This is as strange a thing as e'er I looked on!"

"He is as disproportioned in his manuers

As in his shape."

Over a certain republic in the south of Europe there reigned, once upon a time, as cruel a tyrant as ever filled an absolute throne, or was ever hurled by his subjects from one of those cumbrous seats of a fashion now in course of explosion.

This tyrant was that shadowy potentate called Fear; and inasmuch as the people over whom he had usurped dominion were located in the midst of various gigantic enemies, and 
were exposed at all times to many overwhelming dangers, it might have been thought, though quite erroneously, that they could hardly ever be exempt from the same uneasy rule.

Daily and hourly were their lives in jeopardy from the jaws of reptiles and the beaks of carnivorous birds, large enough to swallow them by dozens at a meal. They were for ever liable to be exterminated by the tread of feet so gigantic, as to put in peril not only their persons, but their habitations. Fragments of rock often crushed them in their fall, and they were frequently borne away and drowned in rapids and cataracts produced by heavy rains.

It was not, however, the fear of these, or of numerous other common dangers, which ever discouraged the labours, or broke the rest, or restrained the enjoyments of our busy republicans, who, with energies usually in full play, built and plannedloved and warred-gathered and feasted; and, in pursuance of all these varied objects, were accustomed to traverse their wide and open territory with feelings of security, just as comfortable as those, we may suppose, indulged in by certain insect hermits, sleek, white, and luxurious, who pass their lazy lives for days and months successive,

\section{"Shut}

Within the walled circumference of a nut."

It was not, we repeat it, the fear of Death always at hand, under any one of his familiar shapes, that ever caused a moment's reflection, much less uneasiness, to a people so entirely vccu. 
pied, as was that we are speaking of, in the business of life; but at the particular period of our relation, Danger, and Death behind him, began suddenly to trip up their heels in a manner so new and so mysterious, as to make the most heedless look very seriously about them, and hence only arose the panic Terror, which came for awhile to lord it over them.

The capital of their republic, which was built upon Italian soil, we shall call Monticello; and it was upon one of the principal thoroughfares communicating with this city, that the common enemy first began that unusual and ill-mannered mode of attack to which we have alluded. 'This highway had been traversed by many successive generations, to whom nothing had thereon befallen, excepting accidents of usual occurrence; but one day, as a party of some eight or ten individuals were quietly pursuing their way along what they supposed to be, as heretofore, a solid causeway, they came suddenly upon the edge of a deep and wide abyss.

Thus taken by surprise, two or three lost their footing, and rolled at once down the shelving side of this strange pitfall. The others might perhaps have maintained their equilibrium, but, blinded and overtlurown by a shower of sand, rising from the hollow before them, as if from the crater of a volcano, they also, with exception of one who returned to tell the tale, were precipitated down the fatal descent.

The road whereon this alarming occurrence took place was speedily abandoned,-it was made, in fact, impassable; but in 
whatever direction the stream of life was turned, there, with magic rapidity and in a mode quite inexplicable, yawning gulfs of a similar description were opened for its interruption.

As these mysterious pitfalls became more numerous, the number of those which fell into them was not augmented certainly to quite a proportionate degree. This was only on account of the greater care taken, in general, to escape them; but under these precautions, and the fear which suggested them, the citizens of Monticello became quite an altered people, their activities being well-nigh paralyzed by substantial hindrances and vague apprehensions. Whenever, according to daily usage and necessity, parties proceeded from the capital to bring in from the surrounding country both materials for building and supplies of provision, they were generally obliged to take such circuitous and untrodden routes, that they were half dead when they returned, from fatigue as well as fear-fear not only of the traps, which were discernible, but of the trap-makers, who had been as yet invisible. None of these, at least, had ever been seen at their mining operations, though some declared they had beheld what they believed to be the agents of all the mischief, in certain strange and hideous shapes met lurking under shade of evening, or of the green coverts adjacent to the city.

It was customary, in the republican nation of which Monticello was the metropolis, to conficle the care of all the infant population to public nurses, who were usually the best nurses 
in the world; but under the alarming visitation of which we are telling, even the care of these faithful guardians began to relax with their courage, and they would sometimes allow their charges as well as themselves to die nearly of starvation, for fuar lest, in collecting food, they might become food in their own persons for the gaping pitfalls or their mysterious fabricators.

It was usual also in fine weather to carry the nurselings, for air and sunshine, beyond the city walls; but since the reign of the panic, they had been nearly all, as in time of siege, immured within their close apartments. But it had never so fared with the infant charges under the keeping of one youthful nurse, who, rather than they should lack any. thing, had continued to encounter all extraordinary as well as ordinary dangers, and that, hitherto, with the most perfect impunity. 'This kind and brave-hearted creature we shall call Piccoletta, because she was but a very little personage, and because, as before noticed, she and her compatriots were of Italian birth.

Well, this Piccoletta, who, according to her deserts, was a general favourite in the city, left it as usual one fine morning, in order to seek provision in the adjacent country; but night came and passed, and so did also the next day, without her re-appearance, and then everybody thought she must have fallen a victim to their newly besetting enemies; but on the second night, the sentinels on guard perceived in the moonlight a limping object approach the city, which, though mag- 
nified at first, by their ruling fear, into one of the dreaded trap-makers, they soon joyfully recognized as the missing Piccoletta. Nothing could exceed the delight of her neighbours at seeing her again, except, perhaps, their desire to know what had befallen her; and when a little recovered from fatigue, and the injuries she had received in her expedition, she gratified their curiosity by the following relation :-

"You may remember, my dear friends," said she, "how I got up by sunrise the day before yesterday, and went out by myself into the country. You know, too, that I never, on my own account, had any more fears about those terrible pitfalls, than if such things were still, as they used to be, quite unknown; but, somehow, on that morning, as soon as I got beyond the shadow of our city walls, my heart seemed to sink within me, and I should have returned directly, only was ashamed. Instead, however, of going on steadily as usual, I every now and then climbed to the top of some rock or eminence, to obtain an extensive view, and wherever I saw before me a dark roundish shadow, there I fancied a pitfall opened, and took a round-about way to avoid it. This tired me not a little, but I was determined to proceed as far as I had intended; that was, to the clump of elder-trees where some of our black cattle have been lately at pasture, and from whence I have often brought fresh supplies of honied milk.

"Judge, however, of my disappointment, when, after so much toil to reach them, I found the elders all cut down (by the 
hands, doubtless, of those two-legged giants who do more mischief in our beautiful world than all other creatures put together), and nothing left of those useful animals I had come to seek, except a few trampled remains which it made my heart ache to look upon. It was too late to go further, but not bearing to return as I went, I resolved to take quite a new beat home, in hopes either of meeting with another herd of our milch-kine, or of finding some of that sweet regetable food which serves us at once for milk and bread. I was intent, cyes and mind, on this search, and had forgot nearly all about the pitfalls, when, all on a sudden, I found myself in the midst of the most delicious perfume-not of flowers only, but of the very thing I was seeking-and saw, to my delight, that $I$ was coming to a large oak-tree covered at the top with a woodbino in full blossom. I knew by the mingled scent that the leaves, both of tree and creeper, must be covered with that precious manna which kind Providence rains for our support. It is true I had a long way to climb before I could reach one of the laden branches, but reach them, thought I, I will, if that Providence do but aid my efforts. I was just about to ascend when I heard a tremendous knocking over head, and on looking up perceived, on the trunk of the oak, an enormous Pecchio, one of those red-headed, winged dragons which, as you know, are amongst our most cruel enemies; but at that moment, would you believe it? I felt no more afraid of him than if he had been a mouse, and only wished myself as 
big as he that I might be able to carry home a greater load of manna. I waited, however, till the creature had flown away, and then began to ascend the tree, taking a winding course to make the ascent more easy, and resting often enough, I can tell you, before I could reach the first leafy cluster of oak and woodbine intermixed. Then I had a delicious rest, and a delicious meal indeed, after which, I took care to load myself with as much as I could possibly carry of the abundant store around me.

"I meant to descend as soon as I had done so, but, what with walking and climbing, I was too weary to move, and, after such a plentiful meal, began to feel drowsy. The heat of the day and the warm scent of the manna and flowers made me grow more and more heavy, till at last I fell fast asleep.

“ How long my nap lasted I cannot tell, but I was first aroused by the sensation of falling, and then entirely awoke in terrible earnest, by coming in violent contact with a something so hard that I seemed almost knocked to atoms. As soon as I recovered a little from this tremendous shock, I looked about me, and where do you think I found myself but in one of those frightful pitfalls I had been, on setting out, so careful to avoid? I knew it by the sloping circular walls of sand which shut out from my view every other object, and discovered myself to be lodged upon the side of this frightful descent, my fall having been arrested by a projecting stone.

"On what was below me I dared not for some time to cast 
an eye; but when I did,-oh! I thought I should have died with terror!-for what should I see at the bottom of the pit but a hideous Ogre, with a pair of horrible pointed tusks, longer than his own head or any of our bodies, and all besmeared with the blood of some unhappy creature like ourselves, which he seemed at that moment drinking in, just as our cattle draw in the sap of the elder and other trees. 1 was much too frightened, at that time, to think how I had fallen, after all my caution, into the monster's den, but suppose, now, that I had failed to perceive it from its being under the oak-tree on the side opposite to where I had ascended, and that in creeping round the trunk I had got directly over the pitfall, though the foliage concealed it from my view.

"The Ogre was a long time occupied with his sickening repast, but at length he let fall the body on which he had been engaged, and rolled his great cyes all round the cavern. He was coming, I thought, to drag me down, but I suppose I escaped his notice, for he returned again to his last victim, as I at first imagined, to devour it, but instead of that he only tossed it several times over, and at last, by a tremendous jerk, threw it out of his den. Then he lay down, and pushing and shoving his great body into the decp soft sand at bottom of the pit, buried himself entirely all but his horrible tusks, which remained sticking up above the surface. For a long while I watched in breathless terror for his next proceeding, but, as he continued quite motionless, I flattered myself that 
this was his way of going to sleep; and now or never, thought I, I must make a trial to escape. I examined the bank above my head, and seeing on its smooth surface a piece of projecting stone, fixed, apparently, like that which was supporting me, I set foot on the steep ascent with a view to grasp it, but on my first step a mass of dislodged sand fell rolling downwards. How I shuddered lest the Ogre should be roused! and so, in truth, he was-that is, if he had ever been asleepfor instantly rising to meet the stream of sand descending came a volley of the same, thrown up, seemingly, by the tossing of the monster's broad flat head, as he still kept wallowing in his soft bed at bottom of the den. I was almost blinded, and thrown nearly off my station, but I contrived to keep it, and in a short time all was again clear and quiet, and nothing but those terrible tusks above the sand showed sign of a living thing in the cavern, except my poor trembling little self.

"If the Ogre's sleep was real, perhaps he had resumed it; but whether or no, I dared not again to set foot on the loose surface of my prison-wall, but kept crouching on my ledge of stone, till I grew as cold as it, and wished myself as senseless, that I might not hear, as every moment I expected, another stir below me, and feel myself being pelted down into the monster's clutches. But hours, seeming weeks, went on, and the Ogre remained still as death, till, as I supposed by the increased obscurity of the cavern, the sun had set. Then, suddenly, it grew darker still; I heard a distant roll of 
thunder, and there fell into the pitfall some great drops of rain. The monster at the bottom began to stir. Ah! thought I, it's all over with me now! and the dust which I felt again in motion assured me that my fate was at hand. I had scarcely power left to cling to my last holdfast, but cling I did, and presently became aware, from a terrific roaring of the branches of the oak above, that it was now a violent gust of wind, and not the movements of the Ogre, which disturbed the sand and was whirling it in eddies round the pit.

"Then came a tremendous erash, and my sole support shook under me. 'Now,' groaned I, 'I am lost indeed!' but in that moment I was saved. Something fallen from above had nearly shut out all remaining daylight from the mouth of the pitfall, which it lay across, and nearly covered. Here and there, however, I could catch a glimpse of light, and, when my terror was a little abated, discovered with infinite joy that the top of my hideous trap was nearly covered by a bough torn by the storm from the oak above. Grasping with eagerness this unlooked-for help, I speedily abandoned my dangerous station, and a moment afterwards heard the stone which had supported me rolling to the bottom of the pit.

"Hope renewed my strength, and by turns elimbing and traversing the branches of my saving arm of oak, I soon found myself again on solid ground, and, with the utmost speed I could put forth, made my way homewards across the sandy plain around the pitfall, which the rain accompanying 
the storm had rendered, fortunately, less toilsome than usual to travel over. Once I looked behind me, and saw the Ogre risen from his disturbed lair, and, perhaps, attempting to overtake me; but there was a good distance between us, and if there had been none, I think I should soon have beat him upon level ground, for he was moving slowly, after a most awkward fashion, and, as far as I could discern in the twilight, seemed to be walking backwards. My dear friends," concluded Piccoletta, "you know the rest"-and thus ended the story of her escape.

The veil of mystery was now drawn in part from before the dreaded pitfalls; but the death which lurked within them was not considered, by most of the listeners to Piccoletta's tale, as a whit the less formidable in the palpable shape it had now assumed. One old sage among them seemed, however, of a different opinion.

"Are we," said this individual, "the brave and wise citizens of Monticello? Are we among the number of those noted republicans whose labours, policy, and military prowess have been lauded for ages even by the most vain and arrogant of all the giant tribes amongst whom we dwell? And shall we, in shameful terror, continue to tremble before one, or perhaps a dozen, cowardly cruel monsters, whose strength lies only in their artifice? for do they not show plainly that they fear to meet us, by lurking for ever under cover of their traps? My counsel is, that a strong party should leave the city, and, 
closely encircling the first pitfall to be found, compel the wily occupant either to stay within and starve, or come out and fall an easy prey to our united force."

This spirited advice was generally applauded, but several weeks were allowed to pass before it was acted on, the citizens of Monticello only strengthening their fortifications, and continuing to keep as much as possible behind them. Of the foragers compelled to go abroad, some, meanwhile, furnished new victims to the still dreaded enemy, till at last, increased scarcity and other evils, the result of measures entirely defensive, seconded so powerfully the advice of the old counsellor, that it was carried into practice. $\Lambda$ numerous party was asscmbled for the first expedition against the Ogres, and, by her own particular desire, Piccoletta went with it.

Under her guidance, the troop marched first towards the pitfall whence she had escaped, not with any view of attacking the Ogre who had occupied, but who they belicred to have been dislodged from it by the storm, but for the purpose of strengthening their bodies, if not their hearts, hy a plentiful meal off the manna, or sweet bread, of the oak from which their little pioncer had fallen.

Having accomplished, without interruption, this desirable preliminary, they had not proceeded much farther before they came upon another excavation of which the ugly character, could they have doubted it, was pretty clearly evidenced by the appearance, near upon its verge, of several dead bodies, 
the cast-out remains of their fellow-citizens. Here they came to a halt, and formed a circle as close and as deep as their numbers would permit, around the mouth of the pitfall, which had been constructed, as usual, in a sandy soil. Thus they remained, still as mice; and quiet as a mouse, too, remained the cat-like Ogre (if Ogre was there) at the bottom of his cavern, which, from the prudent distance of their position, his besiegers were unable to discern. Hour after hour passed, till from very inaction the courage of the surrounding party, which had arrived in tolerable spirits, began to flag. Declining daylight did not augment their valour; and, as surrounding objects grew indistinct, the passing of a moth or bat-even the rustle of a leaf-sent a tremor through the fearful circle. It would have been broken, likely enough, by desertion, under cover of darkness, but for dread of other pitfalls, or their makers, stalking about under the same nocturnal cloak. The night, however, ended without one alarm, except from phantom fears. Piccoletta was the first who suggested that, perhaps, after all, they were only surrounding an empty trap; and was the first also, when morning came, to creep softly and lightly towards its circumference, to ascertain how this might be. She seemed right in her conjecture-no ogre was to be scen at bottom of the pit; but, where the monster usually made his lair, she perceived, as she thought, a round object, like a ball of sand. She beckoned to one of her companions, who, moved by her example and encouraged by her looks, advanced, 
though with no great alacrity, to her side, and both then gazed intently down the steep declivity. One of the two failed not, we may be sure, to look narrowly for the formidable tusks, which, as she had learnt by experience, were sometimes the only tokens of their wily possessor's presence; but not a thing was visible, save the ball-like object before noticed.

Piccoletta was curious as well as courageous. She proposed to her comrade that, by the assistance of each other, they should descend to the bottom of the pitfall; and when the latter (as was not very surprising) looked somewhat shy of the attempt, our little heroine, half-stepping, half-sliding down the descent, effected her bold purpose by herself. Bold as she was, she nevertheless shook, for a minute, from top to toe, when she found herself standing alone in the very print-mark left by the monstrous body of the late tenant of the den.

But cause for alarm scemed none, as she evidently had the pitfall entirely to herself, with nothing whatever near her except what looked below, as it had appeared from above, a great ball of sand-great, in comparison with Piccoletta, or with any of her companions, but very small, as compared with a creature like the Ogre. On the matter of her re-ascent, Piccoletta felt no concern, being assured that it would prove the easiest operation in the world, when performed free of the monster's presence and his arresting volleys.

She began, therefore, with great composure, to examine the 
brown ball which had raised her curiosity, and, on feeling its surface, discovered, to her surprise, that, instead of being hard, it was soft and yielding to the touch. Meanwhile, the people above grew curious on their parts to see what was going on within the pitfall, and some of them, spite of their fears, drew closer to its edge, from which a few fragments, detached by their weight, fell crumbling downwards. Piccoletta looked up with a smile, partly of encouragement to her companions, partly, perhaps, of self-complacency at her own superior courage. At that moment, she heard a slight noise beside her. Turning round, she beheld the ball in heaving motion, and, presently, through a rent in its circumference, appeareda living head. It was not the head of the Ogre; but to Piccoletta, in her terror, it looked something like it, and she thought even that she saw the points of the horrible tusks she had once seen so hideously employed. Then all her courage deserted her, and she fell senseless to the ground.

The lookers-on above shrank backwards in dismay ; and, as if they had beheld the Ogre himself striding up the sides of his den, broke up their circle-liuddled together in confusionand rapidly retreated.

Presently, however, as if ashamed of their cowardice, they stood still, and again turned their faces towards the quarter of apprehended danger. Not a thing was visible on the smooth sandy plain around the mouth of the pitfall; nor, for awhile, above it; but then, rising suddenly from the centre of the 
hollow, a winged form shot upwards, like a sky-rocket. It approached, glittering in the morning sun, then hovered high above the wondering and admiring crowd. "A genius! a genius!" they exclaimed; "a good genius, who has killed the Ogre, and saved us from destruction !"

Even as they spoke, the brilliant apparition descended slowly from its aerian height, and, on four resplendent wings of immense expansion, again hung suspended now close above their heads. But not long did it thus hover-its brooding was as that of a kite orer a flock of dores,-and presently, kite-like, it seized its victim, lifting it from amidst the deluded multitude by help of sharp talons and a pair of crooked tusks, terrible as those of the dreaded Ogre.

Their former fears swallowed up by this new alarm, the discomfited force of Monticello hastened in confusion towards their eity; but, before they reached it, one more of their number was carried off by the same winged assailant, or another resembling it, and rising, in like manner, from another of the ogre pitfalls.

What had become, meanwhile, of Piccoletta? This was an inquiry which, after they were safe within the walls of their capital, suggested itself for the first time to those who had left her in the lurch. When, however, they had time to think of it, they felt shame enough, as they well might, at their base desertion, to control even their new fears of their new enemy, in defiance of whom a small party speedily re- 
traced their steps, and reached, without interruption, the pitfall round which they had been stationed. But there was no Piccoletta to be found, and not a thing was visible at bottom of the excavation; not even the wonderful ball, from whose heaving throes and living outbirth they lad recoiled in terror, before the ascent of the winged form, which, instead of a good, they now looked on, and with pretty sufficient reason, as an evil genius. An hour or two's fruitless search ended in the persuasion that Piccoletta was lost for ever; and, sorrowful for the loss of their little townsfellow, and crest-fallen at the cowardice to which, perhaps, it was owing, the party turned again towards home.

The summer sun had now attained its height, and the baffled Monticellians were toiling onwards under its scorching beams, their dread of pitfalls, ogres, and genii, all nearly overpowered by vexation and fatigue, when suddenly their path was overshadowed; a flapping of heavy wings was heard above their heads, and at the same moment there fell amongst them a-something-from the stroke of which several individuals fell prostrate. The others hastily recoiled; and in the space thus cleared, there appeared in the now sunny road (for the shade had passed away with the onward flight of the object which had caused it) the miraculous ball which they had seen last within the pitfall. It exhibited, as then, a rent in the side, and was now, moreover, somewhat crushed and battered.

So fearfully connected was that ball of wonder with the 
den of the Ogre, and with the apparition of the cruel winged genius, that not one of the gazers dared approach, much less touch it; and, on beholding it again in motion, all drew back, as before, in consternation.

A voice was heard,-it proceeded from the interior of the ball,-and, strangely as it sounded, there was something in its tone familiar to those who heard it. Could it be the voice of her they had been seeking? It was none other; and alarm was all forgotten in joyful surprise when, peeping through the rent in the misshapen sphere, they saw the little head of Piccoletta. Without waiting to inquire how she had got into that world of wonder, or how she had fallen in, with it, amongst lier friends, some of the latter lifted her, ball and all, upon their shoulders, and carried her, rejoicingly, to the city.

When Piccoletta had stepped from out her strange conveyance, numbers of the curious, and now fearless spectators, crowded round to look into its interior; but the first that put in her head (for the most inquisitive on this occasion was said to have been a female) started backwards with a loud scream. "The Ogre! the Ogre!" resounded, and was echoed from mouth to mouth.

What next was to issue from this globe of enchantment? No monster, - not a thing appeared. Indeed, though the ball might have held half-a-dozen Piccolettas, it seemed not near large enough to contain an ogre; and, a little re-assured by this conviction, several other pryers resumed its examination. 
But these also drew back in terrible alarm, when, grinning at them from within the cavity, they perceived the terrible tusks of the Ogre's very self. With desperate resolution, or in desperate fear, they took, however, a second look; when, lo! they perceived, to their infinite relief, that they were only confronted by the monster's eyeless skull; all that was left, except a few other detached fragments, of one, at least, of their redoubted enemies.

The little Piccoletta was as surprised as anybody, on sight of the ugly remains which had been her fellow-travellers through the air. The history of her second escape was soon told. When she awoke from her sleep of terror, on the bed of sand in the pitfall where her friends had left her with so little ceremony, she looked first at the ball, whose issuing tenant had so sorely frightened her; but, through the yawning rent in its side, saw, or thought she saw, that it was now empty. Then she looked at the sandy walls, which rose sloping round her, and, seeing all clear, lost no time in beginning to scale them. This, though a very laborious, she found (as she had expected) no impracticable task, and had half achieved it, when she heard in a tree at hand, the well-known knocking of the great Pecchio.* This time, from her precarious position, it made her heart sink, and, what was worse, caused her foot to slip, so that she fell rolling with a stream of sand to the bottom of the pit. The Pecchio heard and saw her, and, 
darting from his station on the trunk of an elm, lighted on the edge of the cavity, derouring her with his great eyes, and ready to swallow her down his great throat. There was only one place of refuge open for the trembling Piccoletta, and that was the ball beside her, into which, in her desperate strait, she was right glad to creep. But the Pecchio was not to be so easily baulked of his coveted morsel. He dipped his enormous red head into the pitfall, seized with his long bony proboscis both the ball and its shaking occupant, rose with them into air, and dropped them, by good luck for Piccoletta, in the midst of her acquaintance.

This was an explanation, simple enough, of Piccoletta's entrance into, and her exit from, the wonderful ball; but its chief mysteries were still unravelled. Who could tell what that ball had to do with the Ogre and his pitfall?-how it first came there?-how a winged shape, with pinions of expansion many times wider than itself, could lave issued, apparently, from the globe? and how the Ogre's remains were found in its interior?

Who could explain any of these enigmas?

Not, certainly, the citizens of Monticello, to whom all these things were as the work of a magician.

For awhile, after the occurrences we have related, no new ogre-pits or ogres were seen, but the people continued to be frequently carried off by the winged genii which had arisen from out the excarations. 
Under these repeated visitations, they consulted with the old sage who had been the first to counsel active operations against their new enemy. "What now," said they, " are the best measures to be adopted for our safety?"

"Ah, my children!" said he; "safety there is now none. Remember the time you wasted in panic fear and indecision, before you attempted to attack these monsters in their pitfalls, or meet them upon level ground. The ogres and our winged destroyers are the same evil genii under different forms. The first were shapes of immaturity : their bodies were unwieldy, their movements slow and awkward; with the cunning of age, they had the weakness of infancy, and by dint of activity and courage you might have overcome them. But now, you have allowed them to reach their matured and powerful forms, also to multiply their race, which has become too numerous for entire extirpation, and which, in one shape or another, will continue to assail you. My best and only advice, now, is to resume your usual activities; hold your new enemies, as well as those which have always beset you, in prudent, but not in paralyzing dread; attack them when you can, before they have acquired wings to soar beyond your reach; and do this, looking always for help to that benevolent Power who is the only Good Genius of our diminutive race, as well as of the gigantic nations amongst whom we dwell." 
A pantomime, with its machinery exposed, would be a sorry spectacle, stripped at once of its amusing and surprising character; but there are certain pantomimic incidents, of which the theatre is the insect world, and in which the part of harlequin is played by Nature, that cannot be thus marred, for the more they are elucidated the more do they raise our admiration, with always room left (be they explained never so wisely) for curiosity and wonder. Of this description are the marvels which compose the history of the "Formica Leo," "Ant Lion," or Ogre of Ants, on which our "Tale of an Ogre" has its foundation, and to which we must now turn for explanation and completion of what, in that, was left imperfect and obscure.

Under their prominent characteristics, as a trio eminently " Fair and Fierce," we have said something in another place of the "Dragon," the "Scorpion," and the "Lace-wing" flies; and to these we might have added a fourth, in the allied tribe of Ant Lions, which, "fierce," more cunning, and, finally, as "fair" as they, belong also to the same order of Neuroptera. The Ant Lion is not indeed a frequenter, now-a-days, of Britain; not exactly, therefore, a subject for our exhibition; but it has a place in British catalogues, and having, as it would thence appear, been found once, it may still have lurking-places in our island. This conjecture is considered the more probable from its being a native of central France and Switzerland as well as more southern 
Europe. At all events, it is sufficiently rare in this country to constitute a "Lion" indeed among English insects, and, as such, better worth the seeking. The wily and cruel grub of the ant-lion* (the Ogre of the pitfall) is a grey-coloured ring-bodied insect, in form not very dissimilar to a woodlouse, only much larger, and with six, instead of many legs; but its most conspicuous distinction consists in a pair of tremendous jaws, each pointed and curved like a sickle, and forming together a forceps-like weapon, wherewith, being tubular, it can at once seize, pierce, and suck the blood, or, more properly, the acid juice of the ants it preys on. The snare or pitfall of the ant-lion consists of a funnel-shaped excavation, scooped out of sand, in size varied, but most often of about three inches diameter by two deep.* In the bottom of this den the cunning creature awaits its prey; and, not content with the screen afforded by its encircling walls of sand, is accustomed to conceal its whole body within a deep bed of the same material, leaving only its formidable jaws above the surface. When an unfortunate ant happens, by treading too near this terrible trap, to dislodge from its edge a few particles of sand, these in rolling to the bottom apprise the lurker of its victim's proximity. Then, forthwith, more active measures are adopted to ensure the latter's downfall, its concealed enemy beginning to toss up by repeated jerkings of its head successive showers of sand, whereby the busy little traveller is sure, almost, to be 
precipitated into the pit and jaws of its wily destroyer. When its juices are all extracted, the carcase of the victimized insect is thrown out of the murderer's den.

Great ingenuity, industry, and perseverance are exemplified by the ant-lion in construction of his curious pitfall, a work which, as performed either at large or in boxes of sand, several continental naturalists have observed and described. We learn, in detail, from their pages, how that, having chosen (when at liberty for choice) a proper soil-light and sandythe grub marks out a circle for the mouth of its funnel pit; how it then proceeds, having placed itself within this circle, to scoop out the intended hollow, an operation which it effects by jerking out with its broad flat head repeated loads of sand shovelled previously thereon by one leg, that always nearest to the centre of the circle. This, having once described, walking and working backwards, it turns round, and gives relief to the working limb by bringing that opposite into action, thus proceeding till the excavation is complete. Before, however, this desired end is obtained, the patience and perseverance of the trap-maker are often severely taxed in the removal of stones, which, after all the fine sand is got rid of, often remain to impair the uniformity and use of its sliding pitfall. In this task, like Sysiphus, he is often baffled, but he generally accomplishes it at last by balancing the stones one at a time upon his back, and then bearing them backwards up the loose sandy acclivity of his snare. 
Enough of the ant-lion grub, as the pattern in its operations of our ogre's method of attack; but to unravel the mystery of the ogre's magic ball, and of the winged "genius" thence proceeding, we must glance at the Formica Leo in its transformations.

A popular writer thus describes them:- "When the antlion grub is about to change into a pupa, it constructs a cocoon of sand, which it lines with a beautiful tapestry of silk, the whole being less than half an inch in diameter; the pupa itself, when rolled up, filling only a space of about half this dimension.* When it has remained in the cocoon about three weeks, it breaks through the envelope and emerges to the outside-making use of its mandibles to gnaw the cocoon. It then only requires to expand its wings and body to complete its transformation. But this is the process most calculated to excite our admiration; for, though it is not, on its emergence, more than half an inch in length, it almost instantaneously stretches out to an inch and a quarter, while its wings, which did not exceed the sixth of an inch, acquire an immediate expansion of nearly three inches."*

This wondrous process of expansion is exemplified scarcely less remarkably in our lace-wing fly. The construction of pitfall traps, and the pelting of victims into them, is an artifice not entirely confined to the grub of the ant-lion, that of a fly* being said, among others, to adopt them. The practice 
of lying in wait for prey with head alone visible, is a stratagem employed also by the grub of the tiger-beetle, which for beauty, ficrceness, and rapidity of motion stands at the head of our native Coleoptera. The larva of this insect tiger, which is no less voracious than the perfect beetle, is a soft, white, roundbodied animal with six feet, two horn-like tubereles on the back, a head shielded by a circular scaly plate, and armed with a pair of formidable jaws.

The lair of this unsightly, devouring, and cumning monster, when on the look-out for living booty, is a cylindrical loole of its own excavation, wherein, supported perpendicularly by the dorsal appendages above mentioned, it rests hidden all but the mailed head, which nearly fills up the mouth of its hole, and with its jaws expanded on the stretch for prey. If an unwary insect happens to approach, fortl darts the lurker, and suddenly seizing, retreats with its victim, which it drags downwards to devour.

When arrived at maturity, the tiger-beetle exhibits a form as singularly beautiful as in the stage of larva it was singularly ugly, but no less strikingly adapted than the latter to the predacious activity, which, in contrast to the predacious strategy of its early life, is henceforward to distinguish it. Long agile limbs, projecting eyes, and toothed jaws, alike bespeak and fit it for a creature of rapine, and for pursuit of prey in open sandy places; while resembling its mammalian prototype in 
gracefulness of exterior as well as thirst of blood, it displays a richness and variety of colour boasted by few among its beetle brethren of our northern clime. The least uncommon of our seven or eight species is the Cicindela campestris, * seen not unfrequently from March to October, on heaths and sunny banks. It is of a brilliant green, with usually five spots of yellowish-white on each elytron; the legs and breast of rubyred, which mingles also with the general hue.

In the mature perfection of their rapacious strength and destructive organs as animals of force, both the ant-lion and the tiger-beetle cease to be animals of artifice. Devices and the art of devising are only useful to the weak, the slow, the awkward, or the immature. On these, therefore, do we find them almost invariably bestowed. Such the kind compensation of " even-handed Nature!"

* See Vignette to "Insect Morements."

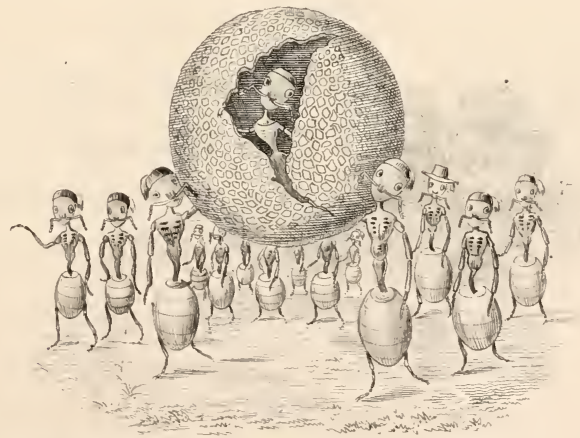

(i) fobe and all then lift ber on their stoulders 


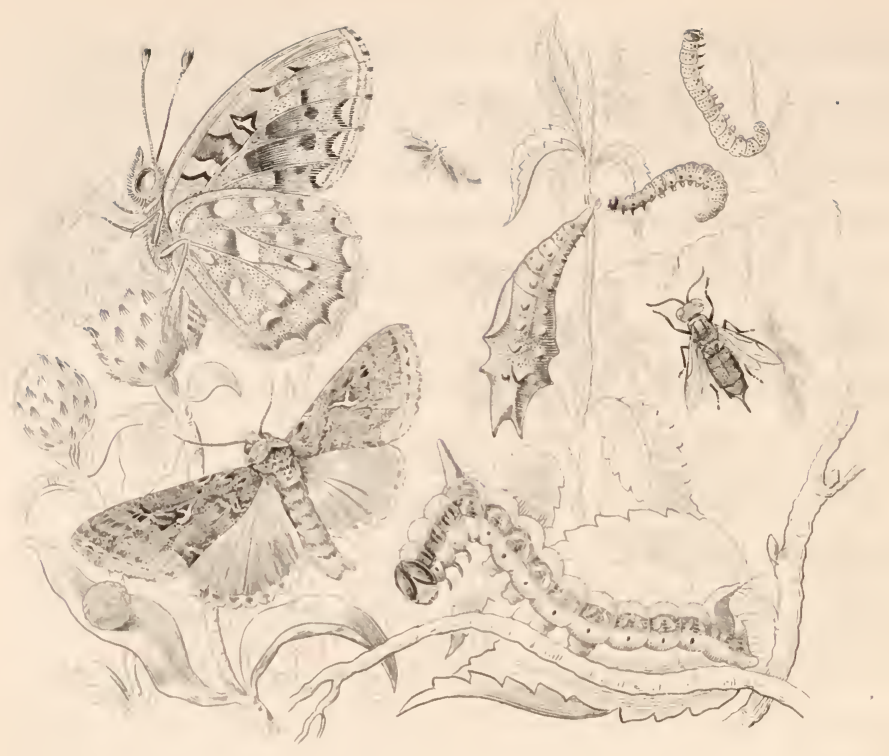

PAINTING, CARTING, ANT GILDING.

" Mark

How Nature paints her colours."

T'He Temple of Nature is no plain puritanic place of worship. It is rather the model of a gorgeous cathedral, and, like a sacred edifice of the latter description, it stands distinguished not alone by features of solemn grandeur-the "long-drawn aisle" whose arches and pillars are the growth of ages, the azure "vault" whose lamps are suns and worlds-but no less by a profusion of adornment worthy of the mighty fabric.

Flowing draperies of foliage, hung on high as curtains or as 
banners-floors tessellated with flowery mosaic, or bespread with verdant velvet-massive pillars and slender shafts marbled with painted lichen and entwined by graceful creepersall these combine, while they immeasurably eclipse the beauty, to attest the origin of Gothic art.

As with this glorious fane, so it is with the worshippers of every degree which are found assembled beneath its aerial canopy. Beauty and variety are the prevailing characteristics of living things; and if in dignity and grace of form man and a few of the larger animals must be confessed pre-eminent, we find in diversity of shape and brilliancy of colouring a striking augmentation as we descend, relatively to size, in the scale of created beings.

Amongst those gifts of creation not essential to existence, but bounteously bestowed to enhance its enjoyment, are those gratifications of the eye for which it is indebted to the colouring properties of light. But for these, what a sombre world should we live in !

"If," says Dr. Brewster, "the objects of the material world had been illuminated with white light, all the particles of which possessed the same degree of refrangibility, and were equally acted upon by the bodies on which they fall, all nature would have shown with a leaden hue, and all the combinations of all external objects, and all the features of the human countenance, would have exhibited no other variety than that which they would possess in a pencil sketch or China-ink drawing; but He who has exhibited such matchless skill in the organization 
of material bodies, and such exquisite taste in the forms upon which they are modelled, has superadded that ethereal beauty which enhances their more permanent qualities, and presents them to us in the ever-varying colours of the spectrum."

Is this a boon to be slighted, or regarded only by the eye as a source of mere sensual, mere involuntary pleasure, when nothing, perhaps, more than colour, sprung of "the Light, creation's mind," is adapted and intended to address itself to the mind of man? To raise our thoughts to their ethereal origin would seem, indeed, a peculiar attribute, not only of those vivid liues

"That live among the clouds, and flush the air, Lingering and deepening at the hour of dews,"

but of those also which invest the living objects of creation. Though falling short usually of this their highest purpose, the more showy of Nature's paintings are wont commonly to exercise, to a certain extent, a striking influence and attraction; and in proportion to the richness, brilliancy, and contrast of their colours are natural objects valued and admired by the many by whom elegance of form and curiosity of structure are almost wholly overlooked. The leopard, the zebra, the peacock, the gold and silver fish, the butterfly, the tulip, all owe their estimation to their colouring; it would seem, in short, a natural, and therefore not an erring taste, to admire what is gaudy; and we doubt whether the natives of the Celestial Empire, who copy in their gay attire the celestial hues of their 
glorious birds and flowers, and yet more brilliant insects, do not thercin display (in common with children and uneducated people) a more accurate perception of the beautiful than that exhibited by people of greater cultivation and artificial refinement.

Those who consider themselves of this select number are accustomed, at all events, to circumscribe taste, as regards colouring, within much stricter limits than those imposed on her by her true model and mistress, Dame Nature.

For certain of our commixtures, such as blue or brown and orange, black and scarlet, black and yellow, Nature, it is true, has afforded us many patterns (in flowers and wings of butterflies); but just as often, and as if to show that she can do all things well, she brings together opposing colours which, though in our hands considered to fall out most abominably, are made under ker authority perfectly to agree.

Blue and green, red and yellow, neither quarrel with each other nor are quarrelled with in a hyacinth, a tulip, a parrot's or an insect's wing, objects to which they never give an air of tawdriness, all such being entirely removed by their exquisite finish and comparatively small size; the apportionment of ornament in an inverse ratio to bulk being, as before noticed, a general rule in the decorative department of nature. How greatly with respect to colouring, as well as elegance of fabric, is the clothing of the larger animals surpassed by that of the feathered creation! This, with a few exceptions, is 
cclipsed in brilliancy by the changing and metallic hues exhibited on the scaly sides of numcrous inhabitants of the deep. These again are equalled, if not outvied, by many of the serpent race; and perhaps the most richly painted of them all would show, but for their superior size, with diminished lustre beside some of the miniature and begemmed encasements of insect life.

Of these cncasements the first are, usually, egg-shells, for which reason we shall make them our first objects of examination. This also is the season when a variety of these tiny caskets, each preserving its jewel life from the inclemencies of winter, are exposed to view on trunks of trees, branches, and leafless stalks, while the prying eye may detect others more cumningly deposited within crevices of wood or bark. Our unaided eye-sight, although it may discover, serves not, of course, to appreciate or even to discern the beauty of these minute eggs which, as well as sceds, their vegetable correspondencies, are excellently adapted to microscopic observation. Through this we shall speedily discover that even the first envelope of insect sensitivity is elegantly ormamented, presenting infinite variety of pattern and of colour. As respects the latter, the eggs of moths and butterflies alone furnish specimens of pink, purple, yellow, grey, green, brown, red and yellow, green and white, $\mathbb{S}_{\mathrm{c} .}$; but it is less with reference to their painting than their carving, that these and others are especially to be noted. In form they are cylindric, flat, prismatic, angular, square, boat-shaped, flask-shaped, anything, perhaps, but exactly egg- 
shaped, after the unvarying type laid down by Mother Partlet, -a diversity always, no doubt, assignable to some kind of adaptation to the exceedingly varied forms of insect life.

There is a curious resemblance both in shape and workings betwixt certain insect eggs and the pretty crustaceous shells called Echina.* Those of the Angleshades moth and of the red underwing have been adduced as instances. That of the meadow brown butterfly is crowned at the upper end with sculptured work in the form of tiles or slates, as if to defend it from injury; while others, as those of the brimstone moth, are covered with a sort of network of six-sided meshes. $\dagger$ The yellow eggs of the large garden white butterfly, found in patches on the leaves of the cabbage, are ribbed and flaskshaped, while those of the lacquey moth, noticed long ago as encircling, bracelet-like, the branches of the hawthorn, are of a singular key-stone shape, adapted to their dove-tailed conjunction. The above slight description of a few only amidst their numerous varieties, may prove sufficiently that insect eggs, in their diversified shapings, mouldings, and markings, are objects not unworthy to compose a microscopic cabinet, for which purpose they should be deprived by heat of their vital principle. And now, while uncloaking winter helps to betray their places of deposit, be they never so cunningly selected, is the time, forthwith, to set about collecting them.

Viewed with reference to their quick formation, minute

* See Vignette.

† 'Insect Trausformations.' 
size, comparatively simple form, and temporary purpose, insect egg-shells, though they cannot be called an inferior, may certainly be looked on as a minor or a mere preparatory production of that beautiful department of animated nature to which they belong. The have seen, nevertheless, how that these are made subjects of ormament, either express or subservient to adaptive design; and it strikes us as curious that sculpture, the species of decoration so commonly bestowed on these coverings of life, should occur but rarely on the living forms which issue from them, till we come to those members of the insect race of all the most perfect, permanent, and elaborately finished-the insects, namely, which compose the Coleopterous order. Here, on the wing-cases of various beetles, on their enamelled and metallic plating, we find again the delicate workmanship which resembles that of the chisel and the graver, and even discern, repeated in numerous instances, the ribbings indented or cmbossed, the raised dottings or the punctures which serve to render an insect egg-shell so elegant a microscopic object.

A familiar example of this sculptured ornament is furnished in the ribbings on the wing-cases and punctures on the thorax of the common dor or clock-beetle, also in various Carali.* The elytra of some of the larger brown weevils, besides being ribbed, are roughened by raised dots; and in the brassy green wing-cases of some of the Donacia, a beautiful tribe of beetles

* Especially in the Carabus clathratus, the wing-cases (elytra) of which exhibit each three embossed lines and three rows of excavations. 
not uncommon upon water-plants, the surface, besides being punctured, is covered with an exquisite species of fretwork which heightens their metallic brilliancy. Even those of the Coleoptera which appear to the unaided eye smooth and glossy, such as the stag-beetle, the ladybird, and some of the burnished Chrysomelicla, or "Apples of gold," exhibit beneath the magnifier minute punctures; and as these punctures, when perforated through the substance of the wing-case, serve, it is supposed, for admission of air to the breathing-tubes beneath, we may perhaps conclude them therefore to be never wholly absent.

Sculptured ornament is a decoration less frequent on insects of other orders, but where present, it would seem, bestowed usually as a touch of finish on those most distinguished by exceeding beauty. That glowing gem of British Hymenoptera, the golden wasp, or ruby-tailed fly,* is thickly beset, body and thorax, with excavated dots; so also, as seen when magnified, some of the exquisitely beautiful parasitic gall-flies; and a sprinkle of these same dottings often completes the elegant parure of those variously formed and manycoloured insects, the Pentatomida, or plant-bugs.

When from insect sculpture we turn to insect painting, we find ourselves in a perfect embarras de richesses, and are fairly puzzled how, fairly, to select for special notice, amongst the miniature chefs d'cuvres of every summer exhibition. 
Shall we begin with the beautiful and glorious mosaics of the butterfly and moth, or with the brilliant and more permanent enamel of the beetle?

With neither; but leaving these most highly-finished and elaborate productions, partially described already under other heads, for only a few additional notices under this, we will first invite attention to a few of what we may call, if the liberty be permitted, the more washy or watery-coloured of Nature's insect paintings, - such of them as resemble most those of the floral kingdom, and are in some instances almost as fugacious, depending like them on the vitality of the bodies they adorn,-paintings, these, the least adapted for cabinet collection, and on this account calling for the more attention to seize, in their brief duration, the hues which belong usually to a short term of existence, and fade with extinguished life. Of this description is the colouring of caterpillars and of spiders, and, to a certain degree, that of dragon-flies and grasshoppers. Amongst the most beautifully painted of the caterpillar race are those from which spring the elegant and distinguished tribe of Hawk-moths, known also as Sphinxes, from the form and attitudes, elsewhere described, of these their no less distinguished larve. None, perhaps, among them are more tastefully decorated than that of the "privet,"** with his doublet of the most brilliant apple-green laced by oblique stripes of white and purple, further adorned along the sides by orange-

* Sphinx Ligustri. See Vignette to "A Midsumuce Day's Drcam." 
circled spiracles or breathing-holes, and finished at the nether extremity by a black and yellow horn.

Little inferior as respects colour is the garb of the Privet's cousin of the lime-tree.* His surtout also is of green, subdued towards the sides, but on the back so vivid as to dim by comparison the brightness of the newest leaves which open round him. His pervading hue is usually variegated on each side by seven oblique stripes of yellowish-white and crimson; his small mitre-shaped head is edged with white, and his six claws are tinged, like the tips of Aurora's finger's, with rosy red. His horn, or tail, is bright blue, and the whole surface of his body is dotted with regular rows of small tubercles, giving to the skin the appearance of shagreen. A granulated skin of this description is a common characteristic of hawk-moth caterpillars, though not confined entirely to their tribe.

Have we, or have we not, described already that harlequin for variety of hues, and Grimaldi for grotesqueness, the caterpillar of the puss-moth?

Whether or no, we suppose we must give place here to a copy, perhaps the liundredth, of an old original portrait of this insect oddity drawn by the pen of Isaac Walton :- " His lips and mouth," says the angler, "are somewhat yellow, his eyes black as jet, his forehead purple, his feet and hinder parts green, his tail two-forked and black, the whole body stained with a kind of red spots which run along the neck and * Snerinthus Tilice. See Viguette to "Insect Movements." 
shoulder-blade, not unlike the form of St. Andrew's cross or the letter $\mathrm{X}$, and a white line drawn down his back to his tail ; - all which add much beauty to his whole body." We must notice by the way, that what in the above are designated "eyes black as jet," are only cye-like spots on the fore part of the broad, fleshy shoulders, which, when "puss" is sitting" up, according to frequent custom, à la Splininx, surround and overlap his head in fashion of a cowl. But it is the pencil, not the pen, which must give our readers the best notion of this (describe it as we may) still nondescript animal. We refer them, therefore, to his picture,* which will bring them, we think, readily acquainted with the original, when, perhaps in next July, they may happen to encounter him perched, not always loftily, on branch of poplar or of willow. The caterpillar "pusses" in existence then will be offspring of parent moths (as yet chrysalides), and slumbering till May in woodbuilt cells within their native trees. On these we have touched already, as subjects of "Life in Death."

We have sometimes found in September, upon elın and lime trees, also on the pear, a caterpillar, of what moth we know not, remarkable for a high protuberance towards the head, resembling an upright horn, with another like a tail towards the hinder extremity. Gayest of the gay is its parure, in a combination of yellow, scarlet, black, and white, and brown (the very colours of the goldfinch), and these so ar* See Vignette to "A Midsummer Day's Drean." 
ranged in stripes and figures, as to form a pattern than which a lady might purchase at a Berlin warehouse one less rich and elegant.*

More common specimens of showy caterpillars are the growth of every garden. Most common of all, the speckled feeders on the cabbage, the striped "lacqueys," and the black and yellow spotted "magpies," which commit their leaf lar. cenies on the gooseberry and currant. Apropos of spotted caterpillars and gooseberry and currant bushes, we may notice that, frequently besetting the latter, and reducing their leaves to perfect skeletons, are certain other black-spotted varlets, which we mention here for the sake of noticing that their spots, or dots, which are very shining, are raised above the surface of their greenish-yellow skins, forming thus another sort of shagreen to that which clothes some of the Sphinxes. This ornamented apparel they are accustomed, on their last moult, to exchange for a plain one, "as people," says Réaumur, "when they advance in years, become usually more simple in their dress than when they were young." Query, Did the old ladies of the days of Réaumur display better taste than they usually do at present? The above-named caterpillars (called pseudo or false ones) are distinguished from the true by having sixteen prolegs, as well as six claws, and become in due season not moths but saw-flies.*

We have room for little more about the colouring of cater- 
pillars, and if we had, repeated descriptions would only serve to weary more than to inform. The eye at a glance takes in, in these matters, more knowledge than a page of descriptive matter can be made to convey. Suflice it that almost every caterpillar is rendered, by colour only, an object pleasing, or, to some people, endurable to look on; and in truth these creeping things would be but loathly ones if stripped of their investiture of light. In proof, we have only to dislodge from their dark retreats some of the whitish wood-borers of the same tribe, and, however little fastidious, we shall confess their unsightliness by an involuntary gesture of aversion. There is little correspondence in colour observable betwixt caterpillars and the same insects in their moth or butterfly maturity, the magpie or currant moth* forming one of the few exeeptions to this general rule.

In many cases, also, the most sober-suited moths, as the brown "Lacquey" and the tabby "Puss," spring from the gayest caterpillars. The Sphinxes and the "Emperor" are, however, handsome moths come of handsome larvæ.

There are few specimens of the flower-like or water-colour painting, if we may so call it, which we are now reviewing, that display more vivid tints, or more elegantly-pencilled patterns, than are sometimes to be found on the bodies of spiders, such of them as are frequenters of the garden and the field. The ungraceful forms of those among the same tribe 
which are accustomed to abide in dark places are clothed in skins of corresponding dulness; but those which live and lurk amongst leaves and flowers seem to have stolen of their lively colours. Green, green and white, red and yellow, red and white, or varied browns, in regular and tasteful markings, adorn most commonly a variety of these spinners in the sunshine or the leafy shade; and when, as with our prying propensities is not uncommon, we intrude on the domestic privacy of one of those broidered Arachnes keeping watch within a a rolled or folded leaf over her treasured eggs, wrapped in a silken ball of white or blue or yellow, we have before us, in our opinion (spider, and spider's nest and nursery though they be), an assemblage of very pleasing objects, pretty in their colouring, and in something more.*

Amongst the less gay, but not least remarkably-painted of this wily race, we cannot overpass that notable hunter, striped (in black and white) like a zebra, and leaping like a tiger, which is sure in the early sunshine of the year to be seen basking upon walls and window-ledges, ready to pounce upon the first unlucky fly tempted to the same spot by the same enlivening and unwonted warmth. $\dagger$ As one of the harbingers of summer, we always look a welcome on this saltatory lover of the sun, or perhaps only of the prey the sun procures him; and, for the same reason, we first espy with equal gladness his 
lighly distinguished or distinguishable little cousin, the scarlet Satin Mite,* whose showy doublet loses nothing by contrast with the ground he traverses.

On the order Neuroptera, including dragon, scorpion, and lacewing flies (that trio of the "Fair and Fierce" already noticed) the pencil of nature has laid some of her most brilliant colours, wanting only breadth to attract more general attention. The linear trunks of dragon-flies are variegated according to their species with yellow, blue, green, and red, each accompanied more or less with black, and exhibit in the peculiar clearness and sharpness of their mode of inlay the appearance more of mosaic than of surface painting. With these, to preserve for the cabinet the hues of life the collector finds it requisite to stuff them,-in other words, to remove the contents of the body, supplying the vacuum with cotton steeped in spirits. By a process something similar, even the more fugacious colours of spiders may be in some degree preserved.

The colours of the Orthoptera, such as grasshoppers, locusts, and crickets, are somewhat more enduring, as infused into harder substances than those last mentioned, though even these, in their greens especially, are considerably given to change. Those accustomed only to the simple liveries of our native Gryllida and Locustida might little expect to behold in foreigners of the same order specimens of splendid painting,

* Trombidium holosericum. 
such as might make the butterfly veil her richest pinions. Many of these insects display on their broad wings or tegmina a variety of colours, translucent and assuming the most brilliant hues when they pass before the light. One of them, the Gryllus morbillosus, a native of China, ${ }^{*}$ is a glorious creature for combination of colours. The tegmina, or wing-covers, are purple and yellow; the wings, glowing crimson spotted with black; the body is ringed by zones of black and yellow; the legs scarlet; head and thorax coral-red.

Speaking in another place of that ill-savoured, but not always ill-favoured family, which bears the name of Bug, we had occasion to remark, that such of its members as are frequenters of the field and garden, and followers of the sun, are arrayed usually in colours of corresponding liveliness : witness the elegant Pentatomida, not more varied in form than in markings and in hues, of which their prevailing ones are black and red, buff, bright green, and variegated brown. We have also amongst our native insects a bug of brilliant blue ; $\dagger$ and the same colour, with other vivid tints, their lustre heightened sometimes by metallic gloss, is displayed frequently on their bug congeners in those foreign climates where on insects, birds, and flowers the gifts of colour are richer and more profusely lavished than beneath our tempered sunbeams. $\ddagger$

\footnotetext{
* Figured and described by Donovan in 'Insects of India and China.'

† Pentatoma carulea.

$\$$ For figures of these, and various splendid and curious insects of the orders
} 
But it is not, as we have all along declared, either our province or our purpose, or desire, to wander far, even de. scriptively, from home; and it is time now to end our brief and most imperfect notices of insect painting, chiefly of the British school, by a word or two on the most admired and most permanent of all Nature's performances in this depart. ment of her grand atelier-the colouring, namely, of butterflies and beetles. But of this, in truth, especially as concerns butterflies and moths, we have little left to say. For the few individual descriptions we have found space to aflord them we must refer our readers to preceding pages and pictures; and as a general observation on their mode of decoration, we have noticed, we believe, that the painting on the wings of Lepidoplera is executed in mosaic, the scales or plumelets of which it is composed being laid upon, or, more properly, inserted through, minute holes in the transparent membrane of the pinion. No niggard of her colours, Nature on these overspreads both sides of her delicate canvas. Some, indeed, among our butterflies are able to display on the reverse of their glorious pinions, as they "ope and close them," a greater show of pattern than that which adorns their upper surface. Of this description are the standards of the "Red Admiral,"* for in these we hardly can decide which are the most "ad-

ILemiptera and Orthoptera, see the works of Stoll, 'Représeutations eolorées des Punaises des quatre parties du Monde,' 1788; also 'Des Cigales, Spectres,' Se.

* Tanessa Atalanta; also "Admirable." 
mirable," the rich and glowing masses of the upper, or the varied and elegant shadings and pencillings of the lower side: the same may be observed of the robes of the "Painted Lady"* and their linings. In many also of our genus Polyommatus, the cerulean blue opened in expansion towards the sky it emulates is hardly more beantiful than that warmer grey beset with mimic eyes, seeming when the wing is erected to look on the lowlier things of earth. Oh! those blue butterflies! in their ethereal beauty, of all their lovely tribe most lovely, from the gorgeous "Nenelaus," spreading his magnificent robes of azure in the blaze of tropic sun, even to our little "Bedford Blue," $†$ smallest of blues, smallest of butterflies, which spreads no less proudly its little inch of pinion in our cloudy clime.

"It is impossible," says Donovan, in speaking of the former (the Menelaus $\ddagger$ ) "to find in any part of the animal creation colours more beautiful or changeable,-pale blue the primary colour, but new tints meet the eye in every direction, varying from a silvery green to the deepest purple, and the whole surface glittering with the resplendence of highly-polished metal."

In sooth thou art a "glorious minion," thou blue-satined sultan or sultana of the East! but we can match against thee the changing splendour, deeper if not so sparkling, of the Purple Emperor of our British woods of oak.

* Cynthia Cardui. See Vignette.

+ Papilio, or Morpho Menelaus.
† Polyommatus Alsus.

§ Called also "Le Satiné bleu." 
Here with the bright investitures of these "children of the sun," have we not reached the climax, the ne plus ultra of beauty and perfection in insect painting? Can decoration any further go?

Not probably in aught that addresses itself merely to the eye; but in the qualities of permanence, indestructibility, and a greater prevalence of metallic lustre, even as a fine enamel is superior to any other painting, so is the colouring of the moth or butterfly, arrayed in plumelets, surpassed by that of

\section{"The beetle, panoplied in gems and gold."}

As well might we attempt to imitate on paper the hues of sapphire, emerald, and ruby, as to convey by painting or description any adequate idea of those exotic jewels of the order Coleoptera, which seem to bear upon their backs the produce of the mine. This is alike beyond our province as our power; but there are enough at home of gem-like beetles to tax our talents at description, to show their poor sufficiency, and to illustrate forcibly the undoubted fact, that "none can paint like Nature."

We have not, it is true, that Esterhazy of his tribe, the Curculio regalis,* with his coat of brilliant scales, likened to " an illumination of all gems." Let him and his diamonded compeers $\dagger$ adorn with their living lustre the mimosas of Brazil; we have at home our pretty little weevils of many colours

* A single specimen of this beetle fetched at Paris $£ 23$.

$\dagger$ Diamond-beetles. 
(which are the nearest allies to the Curculio in form and in habits) peopling abundantly our wayside plants and our shrubs; and there is one among them, in particular, of bluish green, with gold reflexes, ${ }^{*}$ which wants nothing but size to enable it to rival the most richly-bedizened of its foreign relatives. Red, black, purple, and variegated browns, are colours also distributed amongst this beetle-family, of which all the members are feeders on vegetable diet-living plants or decayed woods or seeds ; those which frequent the former being usually arrayed more gaily than such as subsist upon the latter. Curculionida, or Weevils, are of casy recognition by one strongly-marked family feature-a proboscis, snout, or rostrum of exceeding length, enlarged usually at the tip. The shape of their bodies is an oblong square.

There is a brilliant beetle of quite another form and family, the Buprestis vittata (Bande dorée), with whose gold-striped wing-cases the natives of India are said to decorate their dresses and embroider their slippers. Buprestides we have, though none so splendid; but we are not without our Chrysomelida, $\dagger$ or 'Golden Apples' (the name describes their hemispheric contour) which adorn in their natural places the plants and flowers they frequent, and no less, in artificial posi. tions, the cabinet of the collector.

We can exhibit also our gold green chafer (Cetonia aurata), our "Love among the Roses," and, of colour no less brilliant, 
in form more elegant, our "Insect Tiger," "fierce, beautiful, and fleet," the Cicindela campestris, with his emerald wing-cases inlaid with ivory, and ruby-coloured breast and legs, coursing in hot and sandy districts after insect prey. Nor amongst our numerous Carabi, a predatory tribe of usually much more sombre hue, are there wanting some distinguished individuals worthy to compete with the Cicindela, or with the most admired exotics of the beetle race.*

But we must have done with enamelled and metallic painting, or where shall we find space to notice, finally, another species of decoration, which confers on certain among insect forms an apparent relation yet closer with the mineral kingdom,-that semblance, we mean, of gilding, which they not unfrequently exhibit in common only, we believe, with some of the most highly decorated of fishes $\dagger$ and of serpents? $\ddagger$ But it may not be amiss here to unite our two divisions of painting and gilding by Kirby's general view of insect decoration, referring, as it does, to both. In this he tells us, that "Nature, in some, imitates marble; to other's, gives robes of network. Some she blazons with heraldic insignia, giving them to bear, in ficlds sable, azure, vert, gules, argent, and or, fesses, bars, bends, crosses, crescents, stars, and even animals. $\S$ On others

* Especially Carabus nitens.

$\dagger$ As the Gold and Silver, the John-Dorey, the Gilthead, the Schomber auratus, \&e.

$\ddagger$ As the Coluber Atratulla, resplendent in scales of burnished gold, \&e.

$\S$ Ptinus imperialis. 
she inscribes mathematical figures* - points, lines, angles, triangles; on others, again, hieroglyphic symbols and characters of language; $\dagger$ and, what is more extraordinary still, registers on others dates in the Christian era." $\ddagger$

Lastly, now, for insect gilding, or what bears the name, as exactly resembling in effect that process of adornment. From its appearance most frequently on the enclosing cases of butterflies when in their pupa forms, these have obtained, with the pupæ of moths also, the name of Chrysalides and Aureliæ, though many of the former and all the latter are destitute of this decoration. For the most part, indeed, (though the rule is not without very pretty exceptions, $\S$ ) the pupæ of moths being hidden from view, also from the light, enclosed in cocoons, or buried under earth or within trunks of trees, are of various browns, or of a dirty white. The angular and exposed chrysalides of butterflies are, on the contrary, generally gaily coloured. That of the common "Cabbage," something resembling its caterpillar, is greenish-yellow, spotted with black; some are red and black, others green. As if, while even in their darkest state of imprisonment and inactivity, these lovers of sunshine required the light as a very essential to their being, they hang suspended within its influence, and

* Acrocinus longimanus.

$\dagger$ Plusia gamma $(\gamma)$.

¥Argynnis Aglaia, Lathonia, \&c., on the under side of the wings near the margin.

$\S$ In Catocala Sponsa the chrysalis is lilac; in C. Poeta, blue; in Abraxas grossulariata, black and yellow. That of a pretty orange and brown moth, which, as a green looping caterpillar, feeds upon the rose, is of a bright green. 
seem often to reflect its rays upon their surfaces in streaks of burnished gold. These gilded effects are easily to be observed in August among the chrysalides of the small tortoiseshell butterfly (Tanessa Urtica), which, having by that time, as caterpillars, gorged their fill of nettles, are often to be found suspended, head downwards, on the stalks they have stripped, or on some convenient wall or pale adjacent.* Of these, some are much more gorgeously arrayed than others. The aurelia of the "Painted Lady" $\dagger$ is another which well deserves its name for the gold-like streaks and speckles which variegate its clouded surface. That of the Large Tortoiseshell, or Elm, which we have found sometimes suspended to a stalk of grass, has a coat of buff bedecked with silver.

This natural gilding is by no means confined to chrysalides. The $r$ moth $\ddagger$ displays its character in gold or silver on the upper surface of each primary wing ; * another, the " Burnished Brass,"§ owes its name to two resplendent bands which resemble that metal or yellow gold, crossing its anterior pinions; while a tribe of our native butterflies, named Fritillaries, \| not uncommon in grassy meadows, have the under side of their wings adorned with silvery spots and streaks.

But of all the Lepidoptera, none, perhaps, are so richly emblazoned, in proportion to their size, as the minute moths 1 which come of leaf-mining caterpillars, these having been said

* See Vignette.

+ Cynthia Cardui.

$\S$ Plusia chrysites.

॥ Genus Argynnis and Melitaa.

†lusia gamma.

I Of the genus Ecophora. 
most justly to vie with the diamond-beetle and the hummingbird in the rich metallic colours which bespangle their wings. We thought, indeed, till recently, that these " tiny miracles of nature" were without a match for splendour in their kind; but in July 1947 we lighted on a family of little motlss (large, though, as compared with leaf-miners) more profusely laden still with the seeming precious metal. We were prying, according to our wont, into one of our mines of insect treasure-the bark, namely, of a birch-tree, ${ }^{*}$-when we perceived on its silvery surface what seemed a little patch of veritable gold : and, in truth, a splash fresh from the crucible of the richest and the reddest could not have surpassed in hue the wings of the little moth which, till more closely scrutinized, wore its resemblance. Of these, the upper ones were almost wholly covered by burnished gilding, but slightly variegated with opake white and fringed with gold. The insect being at rest, the superior pinions were alone visible, overlapping the inferior ones of dark silken grey. Having first secured, in a convenient pill-box, this gilded fairy, we sought where we had found her, in hopes of falling in with one or more of her bedizened fellows. Not a bit of it; but, on curiously pulling off a fragment of the birchen bark, partially detached by time or weather, we discovered, imbedded in its inner face, some dozen of small white cocoons-a few emptied of their recent occupants, of which the remainder were yet to come forth. 
Was it possible that our beautiful goldwing had issued from one of these silken receptacles? She certainly had, as to our infinite satisfaction was fully proved by the emergence, in a few days, of a brilliant bevy of the like lovely and splendicl little creatures.* Their name we cannot tell, though it may be known probably to wiser entomologists.

Let us examine now a little closer into the real quality of these insect enrichments, which come certainly under the range of that comprehensive proverb, " $\Lambda 1$ is not gold that glitters." The appearance in question is produced, says Réaumur, by a transparent brown varnish laid over a white substance, as in the process of gilding leather by tinfoil covered with yellow varnish, the spots of silver being simulated by the same substance covered with a skin more colourless. The silvery and golden gloss in scales of fish are accounted for in the same manner. The white liquor under them was called " essence d'orient" by the artificial pearl-makers of the days of the above-named naturalist, and they were accustomed to employ it in their manufacture. Why not, says Réaumur, employ in gilding the same matter instead of silver? Lister contrived to imitate the gilding of chrysalides by putting a small piece of black gall in a strong decoction of nettles. This produced a skin, which, when left on the cup or paper, will, he says, "exquisitely gild it." $†$

Alchemists, mistaking these gold and silver semblances for * Sce Vignette. † Ray's Letters. 
what they seem, founded on them an argument in support of their visionary art; but, gilded gewgaws as in this respect science proves them, let us submit them to the moral crucible, and see if we cannot extract from them a something better than ashes, or even grains of gold. We have noticed already that in the addition of colour to the gift of light-consequently in all the paintings and gildings, carvings also, of natural objectsthere are to be acknowledged so many calls upon our gratitude to the Giver of all the gratuitous pleasures thence derived. In the fulness of their gracious purpose, they are not alone recreations to the eye, but illuminated missals to the mind. In taking a review of these natural decorations, we seem also to discern in them at once a pattern and an apology for our natural love of ornament. This, when restrained within due limits, is not, as we take it, so much a weakness as a gracefulness of our nature. All devices of ornament are so many embodiments of taste; and the more these are sought for, the more does the mind of the million require refinement for their production, and acquire a greater measure of it by producing. Our schools of design, what are they but branch establishments from the grand academy of nature, whence come all their models?

The cunning artificers amongst God's peculiar people, the "wise-hearted" in whom "the Spirit of God" had put it "to devise curious works in gold and in silver," were expressly directed to draw their patterns from the natural, in particular 
the vegretable world. There were fruits, the almond and pomegranate, with flowers too numerous for specific mention, assigned as forms for imitation in the moulding of sacred utensils and decoration of garments designed for use and ornament within the holy precincts of the Tabernacle. Through subsequent times have the same all-perfect types continued to be repeated in materials and for purposes of every degree, from plate on the altar to delf on the deal table, from priestly and royal vestments to prints of cheapest fabric; and still are they suggestive, as they over will be, of norel adaptations, exhaustless as the magazine of material furnished by created things for the use, mental and manual, of creative art.

We camnot, therefore, look on it as one of the worst signs of the times that decoration in dress, in furniture, in books, in all things, is now, perhaps, more than ever, made an object. On book-covers, especially, those chrysalidan cases of our winged thoughts, is there not a peculiar fitness in the gilding? In the gay decoration, too, of the works of Nature we may find not only gratification for the eye, but lessons for the heart. In the bestowal of the most superb adornments, and that in richest proportion, on the smallest, and what we are used to consider the meanest, of animated creatures, do we not receive at once a lesson of humility and of confidence?-of humility, seeing that, with the mines of Golconda at our disposal, we could not surpass in splendour the clothing of a Buprestis or a diamond-beetle; of confidence, in the care of Him who clothes 
the insect yet more richly than the lily. But, above all, let us notice that in the forms of nature, whether of flower or of insect, those are always the most beantifully coloured whose wearers are most exposed to the light and joy most to sport in sunshine; and let us read herein that all the moral beauties we would seek, all the celestial hues which should give tone and colour to our varying thoughts, must have their source in Him of whom the sun natural is but an emanation and a type-in that glorious Sun of the world spiritual, from which if we turn away, our soul's best emblem is the darkling, sickly plant, colourless for want of light, or the earth-buried grub, livid and loathsome from absence of its rays.

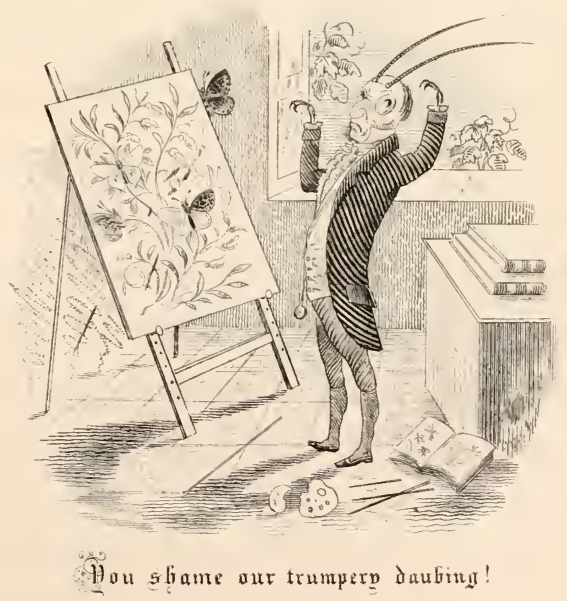




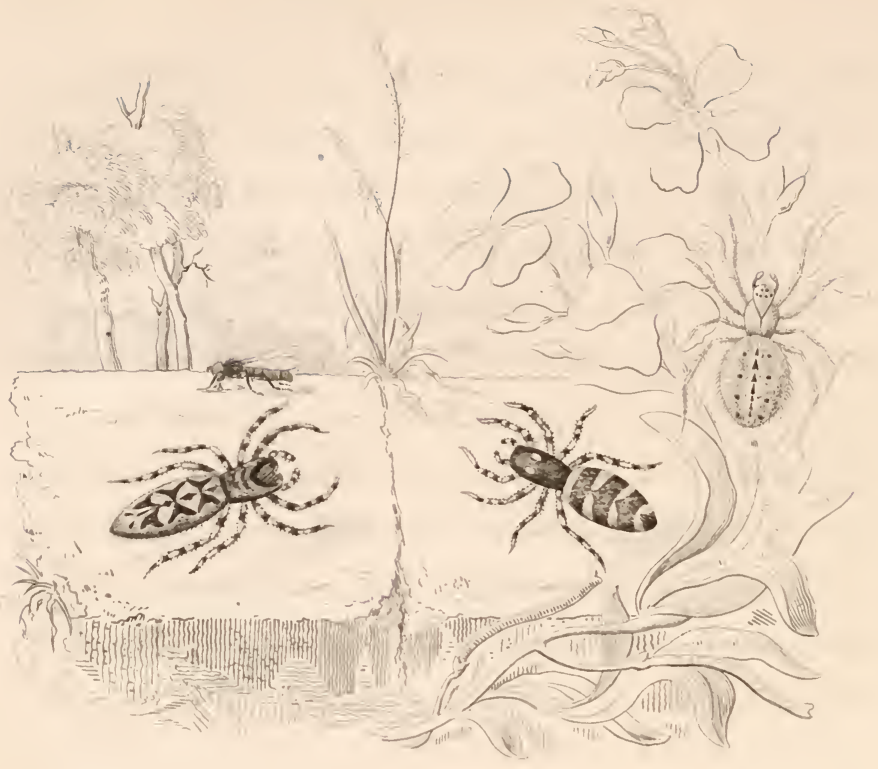

\section{SPIDERS IN THEIR ANALOGIES WITH OTHER ORDERS OF CREITION.}

"Gloomily retired, The villain spider lives, cuuning and ficre, Mixture abhorred! Amid a mangled heap Of eareases in eager watch he sits, O'erlooking all his waring snares around."

Wr have had occasion to notice already a variety of correspondencies obserrable between insects and the higher, or larger, order's of animated creation. In the gentle, as well as predacious tribes, this resemblance is traceable; but with reference especially to habits of destructireness, the Spider alone, in its 
different species, affords the most striking parallel and prototype of all destructive beings, from man himself (we might even say, from the infernal spirit) through the descending grades of quadruped, bird, reptile, animal flower, even to the vegetable of fly-catching construction. Of our moral (or $\mathrm{im}$ moral) selves, in our most ugly features, we have plenty of portraitures clothed in fur, feathers, scales, which to $u s$, through Father Adam, owe all their reflected deformity. In our fierceness, treachery, cunning, in every bad propensity, except two of the worst-avarice and pride-which would seem exclusively human and demoniac, we see ourselves tolerably repeated in the wolf, the tiger, the fox, the bird of rapine, the crocodile, the serpent, the shark, and other creatures instinctively evil, towards which we feel, instinctively, dislike and dread,-partly, perhaps, because they are images so faithfully forbidding of our worst selves. But where the creatures so universally unpopular as those of the genus Aranea? and none, certainly, afford such curiously exact copies of the genus Homo in its characteristics of repulsion, not merely (as represented by other animals) in evil dispositions, but in the particular modes of their exhibition. Who labour assiduously, industriously, ingeniously, for destruction of their prey, but men and spiders? What animals can construct nets and snares for entrapment of their victims? Only (with one or two insect exceptions) weaving spiders, and human fishers and fowlers. Hidden from view behind the gauzy screen afforded by her horizontal net, how 
does the domestic spinner sit grimly on her cunning watch for the least vibration in her lines, those single threads so artfully extended above the main web for a triple purpose-to arrest the flight of her victims, by its tremblings to announce their capture, and as a cable bridge to enable her to reach and seize her prey. "In this corner," says an old quaint translator of Pliny, the Roman naturalist, "with what subtiltie doth she retire, making semblance as though she meant nothing less than she doth, and as if she went about some other business."** With the human lurker for blood, "in secret places doth she thus murder the innocent, catching the poor" (flies, chiefly the starveling and the weak), "when she draweth them into her net."

Besides thus with crafty wiliness seeming to plan and certainly compassing the destruction of others, the spider, by apparent stratagem, often assumes the appearance of death as a means for the preservation of her own life. Who has not often noticed how that, on alarm or pressing emergency, she will sometimes, instead of taking at once to her hairy shanks, only fold them up under her, and, dropping from her station, remain without motion, even (according to experimental naturalists) to the piercing and tearing asunder of her soft bloated body? Herein the spider, in outward act, offers a parallel to the man who throws himself flat upon the ground and holds his breath, to defraud the appetite for living flesh of Master

* IIolland's 'Plinie.' 
Bruin or King Lion; while in her apparent indifference to torturing tests of vitality she enacts a part as closely resembling those of the martyr and the American Indian.

This latter characteristic of seeming insensibility, which is exhibited in an equal degree, under the same circumstances, by the pertinacious Death-watch,* is one (in an insect) of a very curious description. In what can it have its source? Not certainly in anything of resemblance to that iron will, whether strengthened by devotion or pride, which has imparted of its own firmness to nerves and muscles under the scalping-knife or at the stake. One can hardly, indeed, suppose this inflexible resistance of pain to be, in the insect, a quality of mind (animal mind) at all, but would suppose it rather to be a deadening of the senses at the torpedo touch of alarm, a corporeal cloak of actual insensibility kindly wrapped by Nature around a creature armed with no weapons of defence. Thus regarded, the death-like seeming of the spider is an involuntary affection, not a feint; her quietude under mangling and maiming, an indifference, not assumed, but real. But even on a supposition like this, her practices in the above, as in other particulars, are more closely representative of those of the human than of any other animal.

Again, it has been said and sung, that even the wild beasts spare their kind, the destroyer Man alone turning " his fierce pursuit on man." This is not true, the assertion bcing con- 
tradicted by several carnivorous creatures, both of land and water; but the spider follows pre-eminently in the path of the principal and earliest fratricide, by the habit of killing, and, in cannibal-fashion, devouring its comrades, even of the same family. Réaumur attempted to establish a factory of the large garden spiders, for the sake of their strong and beautiful silk; but the factious weavers orerturned his "projet" by turning their fangs upon each other. If it were an agreeable object of discovery, we might seek and find yet a few more corresponding points of character betwixt ourselves and the "villain spider ;" and what is singular, such resembling features are the most apparent in those species of the race which are greatest frequenters of the human habitation and its neighbourhood,-in those which

"Spread their nets, whether they be

In poet's tower, cellar, barn, or tree."

and which, comprising the spimners of house and garden, are of a class called Sedentaries, in distinction to the "Tagrants" and "Hunters," which, using no net, either lie in ambuscade, or roam about, seeking what they may derour.

Now, as the "Sedentaries" are best representatives of preying men, so these latter, the "Vagrants" and the "Hunters," are the nearer prototypes of preying beasts. And first, the "Vagrants," cunning also in their cruelty, bear, perhaps, greatest resemblance to the feline races, springing, like the tiger from his lair, upon their unsuspecting prey. Of these, 
one ${ }^{*}$ forms or finds its ambush in a rolled-up leaf; another $\dagger$ lurks behind a stone or the gaping bark of an old tree; a third $\ddagger$ (as a tiger in his jungle) sits embowered in the thick panicle of a reed ; while a fourth, ensconced, as at bottom of a pit, in the calyx of a dead flower, sits prepared to pounce upon the first unwary fly happening to visit it in search of honey. Besides these, the sweet white blossoms of the hawthorn, and the blossoms white (not sweet) of many umbelliferous plants, conceal, squatted within their corollas, and therefrom hardly distinguishable, a host of white assassins lying in wait to select their victims from amongst the many-coloured resorters to their dangerous neighbourhood.

If the more wary roamers of the forest and the desert have thus their insect images amongst spider "Vagrants," the more daring have resemblances as apt in the bolder "Hunters," such as spring openly on their prey, and, after destroying, carry it for devourment to their dens. On a flowering shrub sits an enormous hairy-leg of this description, on the look-out, we may be sure, for game:-perhaps a swollen blue-bottle, a fat drone bee, or an overgrown crane-fly? No; he aims, or we may almost say he flies, at a higher quarry - at a living prey, lustrous as a gem, swift as the lightning; as it darts from flower to flower, too rapid on the wing for human sight to follow, yet not so rapid as to elude the eight-eyed vision of the monster which has marked it for destruction-not so rapid as

* Clubiona holosericum.

$\dagger$ C. atrox.

$\$$ Aranea arundinacea. 
to outstrip his eight-legged spring, or to escape the eight terrible claws which will soon engrasp the feathered honeysipper, and bear it from its sunny joys to be devoured in a den of darkness.

The "Hunter" here is the gigantic "Bird Spider"* of South America ; its prey, which it equals in dimensions, one of the glittering, quick-winged humming-birds which often, it is said, fall victims to this insect enemy, for bulk and fierceness the lion of its tribe.

Compared with the above, our little native tiger of the same race $\dagger$ may seem a tame and insignificant destroyer ; but not so, we warrant, to its insect prey. This is of that pretty, common species, banded like the zebra, with stripes of black and white. Everybody must have seen them upon sumy walls, and window-seats, and palings (their scorching deserts) from spring to autumn, though not many, perhaps, have derived as much "divertissement" as the "Sylvan' Evelyn from observation of the cunning dexterity with which they watch, then leap upon their prey; when he noticed of these, or of some allied venatores, how that one of them, if it " happened not to be within a competent leap, would move so softly as the very shadow of the gnomon seemed not to be more imperceptible, unless the fly moved, and then would the spider move also in the same proportion, keeping that just time with her motion, as if the same soul had animated both those little 
bodies."* . These "Hunters," at least some of them, though they do not weave snares, can weave nests, usually a close tissue, within crannies and crevices, their common lurking-places.

The Wolf Spider $\dagger$ is another of the "Hunters," which, seizing its prey openly, bears it to its den, a cavity beneath a stone. This carnivorous prowler, which is of a dark greenishgrey, haunts the borders of ponds and streams, and, as well as diving under, can walk on the surface of, the water; and another $\ddagger$ can perform the same feat, either to escape enemies or to pursue game, the various winged insects which skim the face of the same liquid mirror.

The power of fasting for long intervals between their sanguinary repasts, is another characteristic held by many of the larger predatory animals in common with the spider. One of the latter, kept by Vaillant for ten months under a sealed glass, was found reduced only in size, and not, seemingly, in health or activity.

Descending from carnivorous quadrupeds to birds of rapine, we find the latter no less than the former represented, analogously, in their habits of destruction by the spider race in general; while in one singular tribe, the "Gossamers"-popularly termed "Fliers"-the wingless insect approaches yet nearer to the bird in its power of cleaving the upper air, and that, as it would seem, not wafted on their floating lines or webs merely at pleasure of capricious winds, but (being better

\footnotetext{
* Evelyn's Travels in Italy.
}

+ Iycosa saccata. + L. piratica. 
ballooners than ourselves) with a power of directing their own course through the atmospheric ocean. That the object of their aerial flight is also, in part, hawk-like, for the pursuit and capture of living prey, would seem probable from the fact, that within the tangle of descended fragments of flake or gossamer are generally found imprisoned a variety of small winged insects, the remnants, perhaps, of the aeronaut's superabundant meal.

Of these "Gossamers" it has been observed that, "as not only birds, but some squirrels and fish can fly, so there is a species of spider which has the power of floating or moving in air : but creation is full of analogies, pointing to one general Originator, and linking all sentient things into one great family of related fellow-creatures."**

To the devouring and amphibious reptile and the rapacious fish, the spider race no less offers its analogies in economy and disposition. Breathing by means of gills, they are able to dive, and walk under water, sometimes hunting on shore and plunging with their prey to the bottom. In the Diving Spider, $\dagger$ from whose singular habitudes we have spun elsewhere an imaginary tissue, $\ddagger$ this faculty of respiration is further aided by that of carrying down a supply of atmospheric air to her subaqueous habitation: in what manner, has been also described;

* Sharon Turner's 'Sacred History of the World.'

+ Argyroneta aquatica.

+ See "Fresh-Water Syren;" also "A New Gallery of Practical Science." 
and it is only for the sake of pointing to her analogy with other aquatic preyers that we have again mentioned here this very curious inhabitant of our streams and ditches, who may be said, nearly in the words of Darwin, to

"Bathe unwet her oily form, and dwell

Beneath the surface of the dimpling well."

Another rapport between the reptile and the spider is to be found in the venomous properties which, in some species, belong to each. To say nothing of the far-famed Tarantula (founder of the Tarentella), we read of the poisonous spider of Elba, with its mortal bite; and of another pouncing with deadly fangs upon the heads of sportsmen in the cork-forests of Morocco. The bite of our domestic spinner would seem a reality to flies alone, and its venom to exist only in the imagination of spider-haters; yet would the bodies even of these seem to enclose something less harmless than liquid silk, if we may give credence to that tale for the cruel related by Amoureux. It tells of a woman who, on subjecting the spiders in her cellar to the martyrdom of burning, received, as they quivered and burst in the candle, a poisonous ejection, which, entering her eyes and lips, so frightfully inflamed and swelled them as to jeopardize the life which, for her barbarity, she almost deserved to forfeit.

Lastly, the analogy between the fly-catching spider and the fly-catching vegetable is by no means so remote as may appear. It is an opinion generally received, that the latter, such as the 
catch-fly, the Venus's fly-trap, and the pitcher-plant, appropriate to their own nourishment, if not the very juices of the insects they entrap, the air at least evolved from them in the process of putrefaction; and, this admitted, the imprisoning vegetable and the imprisoning animal, the one subsisting wholly, the other partially on the juices of their victims, must be allowed to be tolcrable representatives of each other.

But we have dwelt, perhaps, over long on those exceedingly ugly features of resemblance by which the spider is marked out so clearly as a member of that cunning, ferocious, flesheating family of which we constitute the head. Let us turn now to the brighter side of the Aranea portraiture,-for a brighter side belongs to it. Against spider vices we have, as against human, a set-off of virtues; or, to speak less as of a moral agent, against instincts of abhorrent, we have some of pleasing, character. Foremost among them stands maternal tenderness, or its very image, shown in the devoted care evinced by weaving mothers of the "treasure" they "tie up" so carefully "in silken bags;" and not alone do they care for it while thus enveloped in the shape of little senseless eggs, but when from each egg has issued forth a little sentient spimner. But having already allotted to their careful guardian her deserved place amongst maternal insect worthies, we shall here only notice further, that even by this single point of tenderness in her ferocious whole, she is only linked the closer 
with the predatory race notable, like herself, for love of offspring. Herein the "wolf spider" does but image and emulate the wolf.

Perseverance is another admirable trait for which the spider is eminently conspicuous. No one can deny it;-no one who has ever watched a garden spider in the construction or the reparation of her geometric web, who has noticed her doubling and redoubling the lines by which her fabric is to hang suspended, testing repeatedly their power of support by suspension from them of her own weight as she drops herself, now here, now there, from different portions of the thread. See her in construction of her woven wheel, measuring carefully by her provided ruler-ome of her own legs-each spoke or radius, and each circular mesh which interlaces them; and behold, finally, after all is completed, so neat, and trim, and regular, how that when her cords are sundered by the struggles of some powerful captive-may be, by a Samson bluebottle-she will set to work again so cleverly, so patiently, to repair her broken snare. No; not one of us who have seen her so employed can deny to the spider, apart from her entrapping object, the meed of our admiration and our praise; the latter only a balance awarded in very fairness against the obloquy, unjust, extravagant, which has been heaped upon her by ungrateful man, in return for all her fly-catching services in his behalf. Amongst her revilers is La Fontaine, who, in one of his worst fables, "La Goutte et l'Araignée," 
represents hell as their common producer, thus addressing the insect and the personified disease :-

"Nes filles, leur dit-il, vous pouvez vous vanter,

D'être pour l'humaine lignée

Fgalement à redouter."

Matthiolus, giving another fable as matter of fact, declares that every oak-gall contains either a fly, a spider, or a worm, adding thereto the notable prediction that while the first and third foretell war and famine, the second, namely the spider, comes a harbinger of no less dread calamity in the shape of pestilence. Such cobweb rubbish has been long since swept away by science. As Minerva's needle was fabled once to have subdued "Arachne's rival spirit," so the same implement may be said now to have subdued the spirits of evil clothed by Superstition in $\Lambda$ rachne's form. Herein we should perhaps though make exception of the spirit of the haughty cardinal,* whispered to haunt still, at Hampton Court, the scenes of his inflated pride and forced humility, in the shape of the swollen spiders which are seen at times to issue from behind the arras of those ancient walls.

In the death of the darker superstitions which used once to attach to spiders, the remnant of one more cheerful still survives in the name of the "money-spinner," and the toleration, even complacency, wherewith, in comparison with the rest of her sisterhood, this little visitant is still regarded; and truly 
this shadow of a fancy would be worth the keeping if people would but invest it with the substantiality of a moral such as the "worthy" Fuller thus sets forth.—" When a spider," says he, "is found upon our clothes, we use to say 'some money is coming towards us.' The moral is this. Such who imitate the industrie of that contemptible creature, 'which taketh hold with her hands, and is in king's palaces,' may, by God's blessing, weave themselves into wealth and procure a plentiful estate." No bad lesson, this, for the gossipping gadabouts of the divine's own day, whom he elsewhere appropriately censures as "weavers of streete thread," nor certes less required by their descendants, of our own, the flimsy filandières of gossip-yarn-the spinners of webs of scandal, such as entangle and torture, and have often brought death to the reputation of the heedless innocent.

But while the idle out of mischief may take a lesson of reproof, the wavering or the idle, out of faint-heartedness, may derive one of encouragement from the perseverance of the "money-spinning" family. We have all read how that the royal hero Bruce, when fleeing before his foes a hunted wanderer, took, as an omen and an oracle, the labours of a spider, making his own decision for a last and final venture dependent, with the fate of Scotland, on the success or failure of its seventh effort for attachment of its line. How often has what is called our destiny, be we as individuals great or humble, seemed suspended on a thread as slender, a thread 
we are too apt to look on as a Parce's line, the work of, and liable to be cut in two by, a capricious power out of and independent of ourselves. Let us not be thought for a moment to underrate the power for good of a guiding and overruling Providence; but with humble dependence upon Him for every final issue, let us incline rather to consider this so-named thread of destiny as in most cases, like the spider's, proceeding from ourselves. In the weakness and confusion of our warped judgments and erring wills, it may seem to us a single line, whereas it consists in fact of the double and divergent threads of right and wrong; and according as we discern and lay hold upon the one or the other, will be our real success or failure in the events of life, whose great wind-up is not the business of mortality.

But not only have hope and courage been infused into the heart through the instrumentality of an insect weaver, but when no human shape of charity could approach to cheer it, the desolation of a solitary prison has more than once found assuagement in the welcome companionship even of a spider. Who has not read of M. Pelisson, the hapless inmate of the Bastille, who, taming his little comrade, taught it to come for food at the sound of his flute; and of that other Frenchman, Quatre Mère Disjonval, who, during an imprisonment in which spiders were his sole companions, beguiled the weary hours by watching their movements and proceedings as connected with atmospheric changes, - the observations thus made forming 
materials for a work published in 1797, on Arachnology, or the art of interpreting weather from the webs and motions of the spider race; while in times more recent, " una bella ragna," on his dungeon wall, became the pet of Silvio Pellico. The above and like instances are worth considering. If we wonder how the web of a spider can hang secure, supporting its own weight and that of its occupant on a single line, with no other point of attachment but the bare surface of a wall, must we not infinitely more admire how the heart of man can cling for support to objects most trifling, uncongenial, and repulsive? So let us not deem anything in creation without its moral as well as natural use, seeing that even a spider's thread (to speak figuratively) has been strengthened into a tough cable, helping to preserve from utter shipwreck the mind of a poor prisoner when tossing on that sapping ocean of solitude, which has engulfed some in inanition or in madness.

To return to the virtues of Arachne, we shall close our list of her recommendable qualities by that of cleanliness, wherein she rivals even her direst enemy of the broom, even the worthiest descendant of such assiduous maidens as were wont, in the days of Faëry, to receive ever and anon a silver recompense in the shape of "a sixpence in their shoe." As such a maiden, with her carpet and her curtains, for ever sweeping and shaking, and thereto adding the personal propriety of never failing to "clean herself" when her work is over, so does the domestic spinner with her web, shaking it and 
dusting it, then smoothing down her person, and combing her hairy legs, till no unseemly particle is left to disfigure her attire or abode. In 'Insect Architecture' is given an amusing description of the laborious industry of a spider passenger on board a steamer, in clearing her geometric web of flakes of soot adhering to it from the smoke of the engine, and rendering it unfit for use. Whenerer practicable, she stripped from her lines each sooty particle, and when clogged past clearance, detached, bundled them up, threw them away, and supplied their place by new-spun threads.

'T'o suppose for a moment that a creature so watchful, so ingenious, so acccurate, so tidy, as the one we have been considering, should be blind, seems one of the most curious of speculative notions, yet has it really been conjectured that the web-making artificers of the spider race perform all their operations of surpassing micety, through the nicety, as surpassing, of their touch and hearing. Those who have thus imagined spiders to be destitute of sight, would seem to have so conjectured contrary to the evidence of their own; sceing, as is plainly to be seen, that a number of sparkling gem-like points, if not eyes, exactly resembling in appearance the ocelli of other insects, stud the head or fore part of our spinning Arachnes. These are most often eight, sometimes six in number, varied in colour from black to the clear transparent hue of a sapphire, and are placed in different situations admirably adapted to the habits of each tribe. This provision of Nature 
is remarkably exemplified in those curious, well-known spiders with short roundish bodies elevated on stilt-like legs, which are seen to people in abundance every field of stubble, and are thence called Harvest-men.* These, having no eyes in front, have their one pair on the back, inserted vertically in the sides of an elevated horn or tubercle, so as to afford the animal, in its lowly position on the ground, the benefit of an extended range of vision.

In addition to perseverance and neatness, the spider numbers, as we have seen, amongst her more pleasing attributes a large amount of ingenuity; but we do not enlarge here either on its mode of exercise or the works of constructive skill by which it is exemplified, these having formed subjects more or less direct of former essays. We have done our best to rescue the hairy-legged spimner from unmerited dislike, but withal we leave her, we dare say, much as we found her,-a very unpopular, ugly little animal. Even with reference to externals, it is certain, however, that she is looked on often with an eye of prejudice. As for our domestic Arachne, she, poor creature, as if conscious of her own unsightliness, lurks in shadowy corners, and hides her grim features behind her woven veil. She is certainly not prepossessing; but wherefore, with her, condemn as ugly her out-door cousins, which, warmed by the sunshine into beauty, at least of colour, display a gaiety of hue and variety of markings, such as make up in a measure 
for ungraceful form? There is a beautiful out-door species (white, with zigzag stripes of crimson) which affords, with its nest, an object among the most curious and pleasing of those produced by insect appropriation of leaves. The collection of such foliaceous specimens affords of itself a pleasant pursuit in country rambles. In such pursuit we have often, in July and August, lighted on a leaf (usually of bramble or nettle) with the tip and sides so turned over from the outer surface as to form a perfect triangle, the edges being joined, and all interstices filled up by white silk, which also lines this ingeniouslywrought purse. The purse it is wherein lies hidden the treasured eggr of a maternal spider, and enclosed within is also to be found the spider's self. A brooding bird will desert her disturbed nest, but it is not so with this watching spider. When her fabric is shaken, and even rent partially asunder, she yet keeps guard within, and still maintains it when captured with her nursery, in order to test the duration of her patient care. That has always held out longer than our resolution to detain her, for day after day, even to a week's end, have we found this spider sit, foodless, by her charge, her ferocity abandoned, her industry suspended, her sagacity all directed, not to destroy, only to preserve; for these triangular leaf-nests never seem employed as snares, and never have we detected the purity of their interiors defiled by restiges of slaughter. This pretty insect in her gentle employ, is undoubtedly a pretty object; but well-favoured or ill-favoured, 
bent on ill or employed on good, it is all the same, she is one of the race of spiders, and there is no bespeaking favour for them,-they are still artful, cruel creatures, even, as we began by observing, most close and unpleasing resemblances of our worst selves. So we must go on hating spiders to the end, not to the end of time, but only to the beginning of that happy period when man shall cease to ensnare and prey on man, and to feast off lamb and mutton; and when, grown gentle with all others of regenerate creation, the spider herself, wo longer the ferocious huntress or the sly filandière,

"Prétendant enlacer tout insect volant,"

shall become again the harmless tapissière she was supposed formerly (doubtless, when she lived in Eden) to have been.

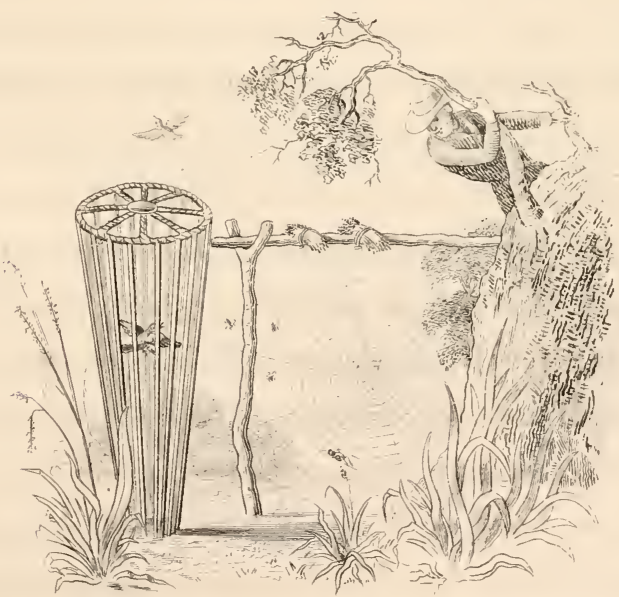

"Snare settun anturafs. mea mol spisters 

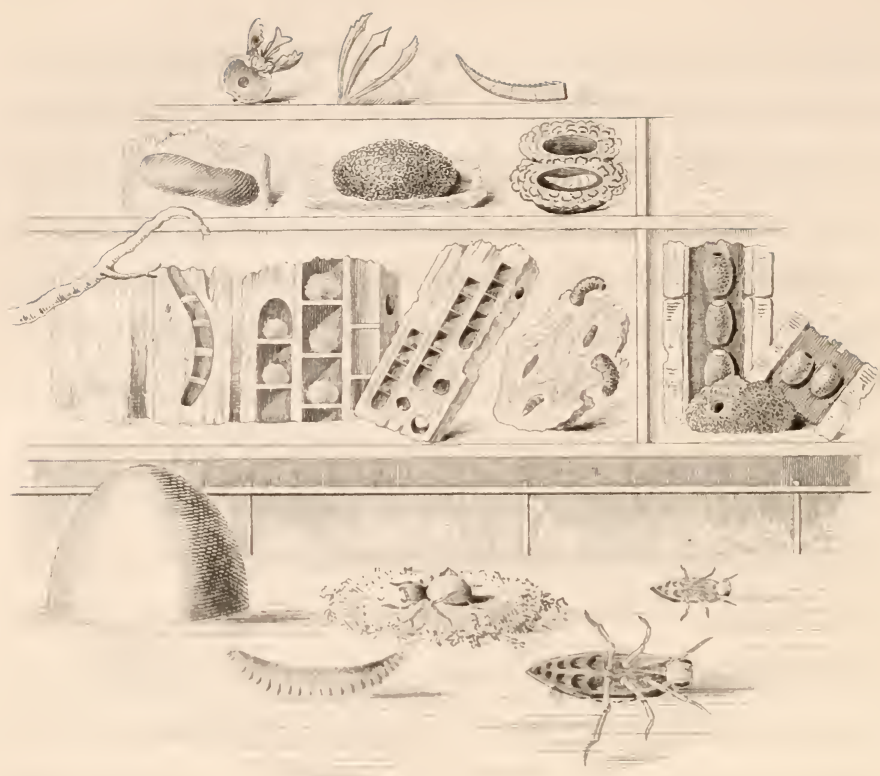

\section{A NEW GALLERY OF PRACTICAL SCIENCE.}

"Is there not art through all the works of Nature?"

Ladies and Gentlemen of a mechanic turn, we can introduce you to a new theatre of exhibition, where ingenious mechanisms, arts, and manufactures are in daily operation. There, without payment of a shilling, you may look upon divingbells and balloons-see bodies propelled through water by the strokes of an internal piston-examine the models of a lifeboat and a raft-observe the effect of cleverly-constructed buoys-behold in practice, or in their finished productions, 
the crafts of masonry, carpentry, spinning, weaving, and papermaking - see the operations of and the implements for boring and tunnelling, the exercises of rowing and diving, with various other clever and curious performances, of which the Polytechnic can do no more, and in many instances does less, than display the parallels. Should you even be of the number who frequent the above-named gallery for its music rather than its mechanisms, for its pictures rather than its philosophy, our theatre lacks not something to suit your humour. We are not without our stringed instruments and our drums, and pictures we can show you of which the vivid colours and the graceful forms come out as if by magic, slowly, and to all seeming, self-arranging, like the tints and outlines of each new landscape in a series of dissolving views. Should you even be of those who delight more in the freaks of nature than in the experiments of art, should you despise the diving-bell and patronize the dwarf, we can treat you with specimens of the singular and grotesque; and as for marvels of minuteness, the ring you may have seen glitter on the finger of General Tom Thumb would serve, if laid upon a table, as a capacious walled arena for the performances of pygmies to whom we could introduce you-minims among mites-not men.

Anon for our exhibition, over which we shall be proud to conduct you; but before we proceed to notice in particular a few of its manifold objects, we shall take leave to detain you, playing, if you will, the part of lecturer, by a few words of 
general reference to the subject of natural mechanism, as affording, or being adapted to afford, copies for the mechanism of art. It has been observed* of plants, that " in the course of ages in which they have been before the sight and attention of mankind, they must have frequently led them to a perception of organizing skill, and of the effect of such combined mechanism, and to many mechanical imitations of it. Every plant is a machine, and may have suggested ideas of construction and arrangement and serviceable mechanisms by which society has been often benefited and adorned."

'This to a certain degree must be admitted; but perhaps the suggestive influence of the regetable world has been much less exercised through its interior mechanisms of organization than through its external forms of beauty. Of the powerful effect of these latter on all objects of decorative art none can doubt; nor are examples wanting, from the Corinthian capital - supposed copy of acanthus foliage embracing a basket-and the Gothic arch and column, obvious imitations of the trunk: and interlacing boughs of the lofty avenue, down to the classic vase, cup, urn, and lamp, moulded, probably, in ancient as in modern times, from patterns set by Nature in flower, fruit, leaf, and capsule; to which may be added an infinite variety of elegant design in fabrics, furniture, and attire, sprung from minds which would never have conceived them but for notions of grace and beauty imbibed, unconsciously, from the contem- 
plation of natural objects. Learnt thus instinctively, through the medium of the senses rather than the intellect, the decorative are often seen to precede the mechanic arts;-witness the elaborate and often graceful carvings which have been found to ornament the rude utensils of the savage. But the mechanisms of the plant, which are many, and the mechanisms of the animal, which are more, require other eyes and other powers than those of the uncultivated mind to observe, much more to convert them to instructive uses. That with the progress of civilization such uses should not have been derived from them to a greater extent is not so easy to account for, and "surprising," we must confess it, "that an animal body (or a vegetable) should have been so seldom taken as a model; extraordinary, that in the history of inventions the telescope and microscope should be modern, when the eye, concave and transparent, might have given rise to imitation as soon as man had learn to give shape to natural and artificial glass." The mechanism of an eye has, however, suggested some valuable inprovements in achromatic glasses, while the structure of an ear has afforded hints for the perfectioning of some instruments of sound. Yet are we still (as Mr. Remnie remarks*) " behind in our arts and sciences, because we have not always been observers. If we had watched the operations of insects and the structure of animals in general with more care, we might have been far advanced in the knowledge of many arts which are yet in their 
infancy, for Nature has given us abundance of patterns." In the obscurity usually involving original inventions (not, perhaps, after all, inventively original), it is difficult to tell how far some of the above patterns, as of common exhibition in certain conspicuous labours of beast and bird, may have contributed to the end of teaching man; but if beavers felled timber, built cabin villages, and laid dams across water, without having contributed, suggestively, towards the like operations among the human tribes surrounding them-if the first mudhut would have been raised as early if the swallow had never been instructed to build her nest of tempered clay, we may engage, with yet more certainty, that the first builder of cemented stone walls never took a lesson from the "mason wasp" or the "mason caterpillar," although (using, in lieu of mortar, the one a natural gluten, the other meshes of silk) they build their walls, and have ever built them, of detached blocks, exactly as we have learnt, somehow, to make our own. So, in other instances, a raft was doubtless man's first contrivance, or more probably his need suggested an expedient for traversing the water; and he by whom the experiment was tried had no knowledge, it is almost certain, that a squirrel and a spider had crossed each its river or its ocean by help of a similar aid.

The use of that most simple yet most powerful of instruments, the wedge, could have been suggested by an operation commonly performed by every species of bee; yet he who first 
hit upon this wonder-working implement would have no doubt laughed incredulously on being told that he was using the same sort of agency to rend, perhaps an oak, as that employed by a bee beside him to effect its entrance or egress through the closed door of a blossom of toad-flax or snapdragon. The insect, in accomplishment of this purpose, rests on the lower lip of the flower, insinuates its tongue between the upper lip and the valve, and then thrusting in its head, acts with it as a wedge to force the shut edges asunder.* It is, perhaps, not surprising that insects, by reason of their littleness, should have failed, as well as more bulky though less clever adepts in art instinctive, to serve as our instructors; yet had only their operations been carefully noticed, or could they, in early ages, have been so observed, hints must have been thence derived such as could scarcely have failed to antedate not only some of the boasted discoveries of modern science, but also those leading arts of building, navigation, and clothing, which the polished nations of the world have been so long in acquiring, and the rude ones have scarcely yet learnt. But if insect operatives and operations have, till of late, been overlooked, it is even less to be wondered at that insect mechanisms, or the instruments with which they operate, should, to us, have proved useless as patterns, seeing that these could not, in most cases, have been even perceived without the aid, on our part, of instruments of observation- 
the magnifying lenses, which have now opened to view, as a part of insect organism, a set of admirably adapted working tools, such as might well have offered models for the furnishing of our own workshops, had not these been provided previously with corresponding and, in some instances, curiously similar implements. Sars, files, augers, forceps, lancets, tweezers, with a variety of other tools, were in possession of insect artisans, while a fish-tooth, or a piece of sharpened stone or wood, were the best implements which uncivilized man knew how to manufacture; nor hardly could he have taken hints from Nature in the absence of those developed faculties requisite for the observation and understanding of Nature's models.

It would seem on the whole, then, that man, as a mechanic, has not yet profited greatly by the pattern mechanisms of animal bodies, or the pattern operations of instinet-taught artificers,_a remark that applies generally, but more especially, on account of their minuteness, to the tools and works of insects. Since these have not hitherto been suggestively instructive, nor were, apparently, intended to instruct uncultivated man, however capable in themselves of such a purpose, were all the perfect means and appliances for constructive labour bestowed so richly on the insect race intended solely for the use and benefit of their tiny possessors? Have they not any reference whatever to ourselves, the head intelligences of creation, with eyes now opened, at least in part, to the admirable 
mechanic powers put into the hands, more properly the bodies, of our little fellow-labourers who cannot make instruments for themselves? We think they have ; for the Giver of all good never, perhaps, bestows a gift for the peculiar use of some, which he bestows not also for the general benefit of all his creatures. Now, then, that these insect mechanisms have been, many of them, brought by the microscope within examination, they may, even as models, afford hints for improvement of some of our present tools or construction of new ones; but even supposing them, as patterns, entirely useless, there is in the gifts and works of the lower animals, of insects in parti. cular, a moral voice awakening both our humility and our pride.

Must not our conceit be lowered on finding that numerous of our instruments, only now perfected,-of our works, only now performed after ages of bungling attempt and failure, have been, since the world began, the former possessed, the latter effected, by diminutive creatures holding one of the most despised places in the scale of creation; while even of the boasted discoveries of science not a few have been anticipated in the laws which regulate the movements and mechanisms of the same insect bodies? From the above facts spring, on the other hand, reflections no less calculated to make us proud, rationally proud, of our pains-acquired implements and comparatively slow performances. If we consider the admirable operations and curious structures of the insect race, as conducted and constructed under the most instinctive 
guidance, in other words, in peculiar accordance with Divine tuition; if we see in their perfect tools and unerring mechanisms so many palpable tokens of the Divine "contriving mind," then are all our involuntary imitations of these implements and works so many unconscious copies from Divine models, and, as such, so many corroborative tokens of our proudest distinction, that of having been formed, mentally, after the Divine image.

Now, ladies and gentlemen, our preparatory lecture ended, it is time to point out to you, as we promised, a few of the most striking objects in our exhibition-the miniature gallery of practieal science with whose programme we commenced.

Following an arrangement something similar to that adopted at the "Polytechnic," let us begin by a survey of what we shall denominate our hall. Around it flows an artificial canal, on the surface of which, stationary or in movement, we see a variety of what look, at a little distance, like diminutive model boats. Here are some of them propelled seemingly by oarsself-moving oars-for no rowers are discernible. Each craft, through some internal mechanism, is self-acting, is its own rower; it is, in fact, as we perceive on closer scrutiny, a living thing, one of the things which, under another aspect, that of murderous pirates, we have elsewhere glanced at.* These living boats, of which the like may be seen gliding in summer on the surface of every pond, are, in short, none other than 
boat-flies; and most appropriately are they thus named. See, as they strike out regularly with their oar-shaped feet, how they cut through the liquid element with their keel-like backs, their flat stomachs raised uppermost to form a deck, their broad, beaked heads the prow, their pointed extremities the stern.*

One of these we may lift from the water and examine more at leisure another time; but now, let them "row on," while we admire another less animated, but on that account not less perfect model of a boat-a life-boat-as it rests stationary near the edge of our canal. How exactly does this object correspond with the description given of it by a noted observer! How closely does it resemble "a London wherry, sharp and high, as sailors say, fore and aft, convex below, concave above, and always floating on its keel." But is it really thus buoyant? Let us test it. See, now, as we pour water from a height above it, how it refuses to sink, and as it bravely floats shows not a drop of water in the hollow of its deck.

But of what is this tiny boat composed? and who the builder? In lieu of horizontal planks, its sides, as we lift it from the water, show an array of pyramidal bodies, small end uppermost and compacted close together. Of these bodies let us detach one from the mass, and see whether it will sink or swim. It sinks. So it was only by their adherence and their conjunct form that the whole were supported in the water lighter than themselves. But this fragment of our boat, 
what is it? It is an egg-an insect egg-laid by a mother gnat, instructed by Nature to commit those eggs to water, and, for their preservation on its surface, to build out of them a raft, or life-boat, such as we have now before us.*

Not far from this we perceive another buoyant object, which, on looking closely, has somewhat the appearance of a minute fish suspended head downwards in the water. A fish it is not, but a gnat larva, which has lately issued from the egg-built wherry, of which its deserted egg-shell still forms a component part. By what means, what apparatus, is the little swimmer thus supported? Our pocket magnifier may perhaps disclose the mystery. All! here we have it! He has no life-preserver round his body, but from the last ring of it branches off at an angle a short pipe or tube, through which the diver takes in a supply of air. Nor this alone, for being terminated by a sort of fumnel composed of oily hairs which repel water, this same tube serves the purpose of a buoy, which, assisted by another of like construction at the end of the tail, suspends the swimmer in the water. To descend, lie has only to fold up the hairs of this funnel buoy, retaining at their ends a globule of air, and to re-open them when the fancy takes him to mount again to the water's surface.*

Let us next turn to that curious piece of floating machinery which is now approaching us. But we see, our friends, you look incredulous. "Machinery !" you exclaim, "why we see 
nothing but a little ugly monster with a great head and staring eyes, a reptile-shaped body, six hairy legs, and a sort of triple pointed tail."** True, but let us watch its progress through the water, with which, as we shall find presently, those six legs have infinitely less concern than the tail, that triple, or, more correctly, quintuple pointed tail of which you spoke. Now this anal apparatus forms, in fact, the mouth of an internal pump or pistorn, made instrumental to the motion of the body which contains it. See how these little fragments of paper which we throw into the water are alternately drawn towards and repelled from the instrument in question; and drawn in, in like manner, is a portion of the water, which, regularly imbibed and rejected by the insect's pump, forms a jet which propels the creature through resistance of the mass of fluid in its rear.

To show more clearly the working of this curious engine, suppose, in accordance with a plan suggested by Mr. Rennie, that we let down carefully, by a glass tube, over the mouth of the pump-in other words, over the insect's tail-a coloured solution. Ah! we can see clearly, now, how he ejects it in a stream which marks for several inches his wake upon the water. Here then we have that pattern for the propulsion of a vessel of which Paley thus speaks when writing, in 1802, of discoveries or projects in imitation of Nature.

"Some years ago," he says, "a plan was suggested of producing propulsion by reaction, this way. A stream of water

* See Vignette to "A Summer Day's Dream." 
was to be shot out of the stern of a boat, the impulse of which stream upon the water in the river was to push the boat forward. It is also the principle by which sky-rockets ascend. Now, if naturalists are to be believed, this is exactly the device which Nature has made use of for the motion of some species of aquatic insects."

The living body, the action of whose motive apparatus we are now observing, is the larva of a dragon-fly, and its curious pump performs for its possessor two other important services besides that of propulsion; - the one is to furnish it with a supply of air, the other to bring within its grasp, by means of the reverberatory current, a number of the lesser water-insects which coustitute its prey.

Time will only serve now for notice of one more object in this, the aquatic division of our exhibition, but that is an object worthy, like the diving-bell of the "Polytechnic," its artificial prototype, of particular attention. Yes, amongst these miniature models is one, as we shall show you, of a divingbell; though you will hear no tinkling notice of its working and descent, inasmuch as it is usually stationary, or only moveable at pleasure of its diving occupant, of whose intentions it would be a difficult matter to give notice.

Well, here, beside the edge of our canal, moored to an aquatic plant by some silken cables, we perceive, submerged all but the top, a bell or dome not very dissimilar in size and shape to the half of a pigeon's egg. Like that, and like a 
diving-bell, it is open at bottom; but this is an assertion which, perhaps, ladies and gentlemen, requires proof.

To give you on this point entire satisfaction, we will raise from the water and reverse our diver's habitation, even at the risk of disturbing its occupant, who has been also, we must tell you, its ingenious constructor. There,-the bell is uplifted, and we see him sitting within it, head downwardsa somewhat strange position; - but it seems we have fairly routed him. He falls! - falls, though, upon eight legs, and makes off at full speer, no matter whither. Our business now is with his vacated abode, - a dome woven, as we now see, of close-spun silk,-open, as we said, at bottom, impervious at top, with no orifice for entrance of water or of air.* Unprovided with a pipe or other visible contrivance for conveyance of the latter, how, we may inquire, did our submerged diver manage to respire under water? Why, in truth, he is somewhat of an amphibious animal, but he nevertheless finds it convenient to take down with him from upper air a supply of the vital element, which he not unfrequently returns to fetch. Is it by means of an air-pump that he collects his supply? Not exactly; but by help of a curious inhaling or imbibing instrument carried at the tail, and called a spinneret, because it serves also the purpose of spinning-helping him to spin his bell-like and aquatic habitation. And now we may tell you, if you have not already discovered it from our glimpse, on dis- 
lodgment, of his retreating form, that our diver is a spider, -the diving water-spider* - a species of whose habitation and habits you may possibly remember some other particulars as recorded in a certain Episode yelept "the Fresh-water Syren," an imaginary personage sprung from this aquatic Arachne of our streams and ditehes, where, shining in its native simplicity, her silver diving-bell is often to be seen.

But we must leave, for the present, these aquatic mechanisms, though as yet but half examined, that we may bestow a little of our notice upon a fer other assembled specimens, first, of the work-animalship, next of the admirably adapted lools enuployed by insect artificers in their exercise of several crafts wherein they have set us, for ages immemorial, a variety of uncopied patterns. Of their masonry, carpentry, spiming, weaving, and paper-making, we can show you here some primitive specimens cither completed or in progress. Let us attend first to the arehitectural operations of these masonic builders, not working in concert, but each employed on a separate structure. The may mention, by the way, as a fact not bespoken very clearly by their apparel, that each of our ouvriers (more properly ouvières) is of the feminine gender. Here is one of them, a sharp, waspish little animal, busied up, to her eyes and ears in our own material for building, bricka single brick-one being big enough to serve her turn. Chipping away her hardest with a trenchant tool, combining 
the uses of a sharp double pickaxe and a pair of forceps, she is employed, seemingly, in the work of excavation. To do her justice, we cannot but admit that she never leaves off

"To play, or to idle, or chat."

Yet for all her assiduity her progress is but slow, for as, piece by piece, each about the size of a mustard-seed, she scoops into her hard material, she carries off each particle to some distance from the scene of operation.

Her patience does not seem to tire, but ours in truth does, or would, if we watched her to the termination of her task, at the end, perhaps, of some days hence. We must leave her, therefore, to complete it, and that with the less regret because we happen to have learnt from other more inclefatigable observers that, her excavation finished, she will proceed to plaster it with a coating of clay, and then close up its entrance with a layer, twice the thickness, of the same material.

We may take a look now at the more rapid proceedings of another independent labourer, also a female, and in appearance and attire not unlike the last. Like her, she also is an excavator, but she is something more,-more of an erector. She is employed (her tools nearly similar) not upon a brick, but upon a block of hard sandstone, which she however moistens, as she works, with a convenient salivary fluid. Each few grains of sand that she thus detaches we see her kneading into a little pellet, and with the like moulded masses (her unbaked bricks) she has built already a circular wall or rampart round the 
edge of her excavation. Thus proceeding, as her pit deepens ler tower rises, and will rise still, to the height, perhaps, of two or three inches. We may find fault, perhaps, with the masonry of her walls; they are by no means perpendicular,like, rather, to those of the leaning tower of Pisa ;* nor are they certainly very solid or compact, looking somewhat, with their open interstices, as if riddled by fairy shot; but our little architect knows well what she is about, she intends her erection to serve only as a temporary tower of protection while at work, and its separate pellets (her pile of bricks ready to her hand) will soon be wanted, and soon taken down to line, to wall up as it were, the sandy sides of her excavated cell.

In the two architectural processes we have just been watching, we have seen the several operations of excavation, plastering, and the raising of walls by the piling on each other of separate artificial masses, wanting but size to constitute them bricks or blocks. Ask you now the purpose of these arts in their miniature exercise, and the name of their tiny exercisers? The latter, whom perhaps from their exterior you may have known already, are wasps, not vulgar and social, but solitary in their labours, "mason" wasps, $†$ mother wasps, and they are scooping their caves, and raising their towers, with no selfish, no ambitious, no mercenary aim, but under the nobler, tenderer impetus of maternal love, and to provide secure asylums for their nurseling young.

* See Vignette.

$\dagger$ Odynerus. 
Contiguous to the above we see some completed specimens of masonry of a somewhat different construction, the work of another yet allied class of builders. Here is a dome-shaped tenement, composed apparently of mud or clay, and looking at a distance not unlike a roundish mass of the former thrown by accident against a roadside wall. Such a site it did indeed once occupy, before removed to this our gallery of exhibition; but only let us examine, and we shall see that instead of a chance-thrown lump it is a pains-reared erection. Its walls are in reality of mud or clay, kneaded into pellets, which being, while moist, laid one upon another, adhere closely and without interstices. A round, open orifice constitutes the entrance to this solid building.* It is too small for discernment through it of any interior arrangement, but that in the specimen before us we can lay open by temporary removal of the exterior claybuilt dome. Within it we now discover two separate cells or chambers "of the form and size of a lady's thimble, finely polished, and of the colour of plaster of Paris." This material is not clay, but apparently the mortar of the wall on which, as we have said, the whole structure was originally placed. The cells, with their outwork of concealment, were once the nurseries of young bees of a solitary species, $\dagger$ and their mother, one of the "masons" of her tribe, was the clever architect and patient builder of the entire edifice.

Here are several other not very dissimilar structures, trans- 
ported carefully, together with their foundations, from the sites, usually brick walls, which they originally occupied. Their variations are in the general form and position of their outworks and cells, ${ }^{*}$ and the materials of their composition, which consist, in different specimens, of clay with particles of stone, mortar, sand, and earth, but all quarried grain by grain, agglutinized in masses or pellets, and compacted whilst moist and adherent. They are cach the work of artificers of the same craft, "mason bees," who, for a similar maternal purpose, have laboured, solitary, but, doubtless,

\section{"Hcart-soothed and busy as a wren, \\ Who in some sceret nook \\ Constructs her sight-eluding den, \\ Beside the running brook."}

Next, in the compass of a flower-pot, we see an edifice, earth-built, but as widely differing from those last under notice in form and structure as its ingenious architects, which are not single but very numerous, differ in shape and size from the mason wasps and bees at whose works we have been looking.

We were presented in the latter with strong walls built of cemented masses; in the one before us we see not only walls but arches of considerable height, of which the excellence and wonder consist chiefly of their being raised of particles of earth, piled up and supporting one another, without the help of any adhesive substance. The building before us is, indeed, 
supported partially by the stems of a plant, which also occupies the flower-pot; but the little masons by whom it was erected possess intuitively the dexterous art of joining grains of dry sand, so as to support one another- " on some similar principle," supposes a nice observer, " to that of the arch."

Beneath the arches thus wondrously erected are chambers, upper and chief ones, lower and ground ones, all, or most of them, appropriated as nurseries, for the eggs, cocoons, and pupæ of-what insects we need hardly tell you, since the active artificers are now many of them to be seen. Any one can tell them to be ants; but all may not know them, by their tiny dark brown bodies, to be "turf-ants,* one of the commonest species of the masons, and so called from their practice of building usually round a tuft of grass, for the sake of the support afforded by its stems to their earthen walls.

Various other structures, something of this description, are here collected;--some under glass-frames, through which we can discern the little labourers at work upon the earthy, clayey, or sandy materials with which they are supplied. We have not time now to watch their proceedings, and can only observe further of their edifices, that some of them are much more complicated, intricate, and complete than that of our turfite in the flower-pot. Presenting usually the outward form of a simple mound or hillock, they, in some instances, $\dagger$ contain within " thick earthen walls, well-marked stories, passages, and large 
chambers, with vaulted ceilings, resting upon a solic base," while, in others, the work of one of the cleverest and eke the smallest of the mason tribes,* our admiration is excited by "storied buildings, with partitions but half a line in thickness, the substance of which they are composed being so finely ground that the inner walls present one smooth unbroken surface. The arched ceilings which cover the most spacious apartments are, in these marvellous interiors, supported either by little columns, slender walls, or by regular buttresses."

From the observations of Huber, who thus describes them, it would appear that these accomplished builders, being provided with no other cement, are indebted to the rains and dews of heaven for sufficient moisture to ensure the coherence of their building particles; and they owe to the rain a further obligation for consolidating, when finished, their delicate walls, which one might suppose, ignorantly, that a summer shower, with its "Niagaras aux fourmis," would be much more likely to wash down and annihilate.

We can devote now but little more attention to insect masonry, or to the specimens of that art here assembled; but in addition to solitary wasps, and solitary bees, and social ants, which exercise their skill in this rocation, there are other labourers in the same, whose works we must not wholly overlook, though they are more simple, and performed under a more selfish impetus, - for the purpose, namely, of self-preserva- 
tion during their own trying time of change and state of torpor, instead of, as with the mother bee and maternal-feeling ant, having for their end the protection of their helpless young.

Here, then, is a mason caterpillar,* no "lean," but truly a very fat, full-grown artificer, recently dislodged from underground, together with his newly-made and hardly finished habitation. The latter is of oval shape, very rough without, very smooth within, and tapestried with silk. This we can discern through a broken aperture at one end of the cocoon, and through the same opening we can also see its occupant employed even now in reparation of his damaged wall-a wall it may properly be called - a wall of earthly particles, held together, not by cement, but by silken threads; for the builder before us unites the art of weaving to that of masonry. A supply of earth has been placed within his reach, and, taking grain after grain in his forceps jaws, he fits them into the breach of his cell, securing each with silk spun as required, the coarser particles being selected for the outer, the finer for the inmer side of his wall. He has nearly closed the aperture; but what means he now by cessation of his grain-laying to collect and carry in a portion of his provided material? This he has accomplished; and now he proceeds to weave over the small opening yet to close a thick silken net-work, into the meshes of which he keeps thrusting from within grains of the earth, which he had, evidently for this purpose, taken in, and, as he * Of the Water-Betony Moth: Cucullia Scrophularia. 
thus thickens his bit of new wall, we gradually lose sight, behind it, both of the builder and his operations; but we can guess at their conclusion, for, having thus made whole again, externally, his damaged domicile, there is little doubt but that he completes it within by restoration also of its soft and silken tapestry.

But, in truth, we must have done with masons, be they wasps, bees, ants, or caterpillars, or we shall have to overpass entirely that department of our gallery allotted to the labours, and exhibiting the works, of those amongst the same insects which are used to exercise the craft of carpentry. Various of them are here employed as in their native workshops, furnished "with all appliances and means" for their ingenious operations; but the progress of these we have not time to follow, so must be content, for the present, with inspection of some articles or architectures, the produce of their tools-more properly their tool-that compound chisel, plane, and forceps, all (as in the masons) united in the jars or teeth of our carpenter artisans. As with the masons, also, all these carpenter's amongst wasps, bees, and ants are females; all work under the prompting of maternal love, or an affection of resembling kind; their buildings are all nests; their chambers nurseries for the protection of, and furnished usually with supplies for, their respective young.

Not as one of the most perfect, but as one of the simplest of these collected specimens, let us look, first, at this nest of a 
carpenter wasp.* It consists merely of a tunnel or gallery, excavated perpendicularly in a piece of wood, softened somewhat by decay and divided into separate chambers (two of them) by partitions, formed of the saw-dust or grains of wood produced in excavation. One of these nurseries has an occupant (once a living one), a young wasp in its grubhood, enclosed in a cocoon of its own spinning, and surrounded by remains of flies and caterpillars, its maternally-provided store.

In this nursery of a solitary bee, we are presented with an example of more finished carpentry and more laborious construction. It is wrought in a material like the last,-in a piece of wood, namely, somewhat softened by decay, part, probably, of a post or pale. The tunnel, which is more square than round, is smooth within, chiselled as if by the tool of a veritable carpenter, and divided into as many as six separate cells or compartments, of which the partitions are no thicker than a card, and formed, not of sawdust (that having been carefully removed), but of kneaded clay, fetched as laboriously by the little builder, who herein shows herself an adept in masonry as well as in her own peculiar art. Within these cells, or some of them, is a portion of pollen, that more inmocent or innocently-gathered food, with which the bee-mother supplies her brood, in lieu of the living larder provided by the maternal wasp.†

We are handling now what may be looked on as a perfect * Of the genus Eumenes. $\uparrow$ See Vignette. 
chef a' auvre in inseet joinery. It is the nest of a third apian carpenter, called, from the beantiful colour of her wings, the violet bee.* She is not, indeed, a recognized native of our own island ; but we can, nevertheless, in this her workmanship, admire and do justice to her constructive skill.

The matcrial, wood, as in the former specimens, is, in this, perforated by several tumnels cut for about an inch obliquely, then in a perpendicular direction. Wach of these tumnels is about a foot deep by half an inch wide, and divided in its length into separate cells about an inch in depth.† We may remember that, in the structure last examined, the work of one of our British carpenters, the perforation was divided in like manner by thin partitions of clay, whereas, in the specimen before us, the material of these divisions is sawdust, or the little chippings produced in excaration, which, instead of removing, our artificer took especial care to collect in a heap beside her nest. Her mode of proceeding las been thus described. Her tumnel finished, "she deposits at its bottom a single egg, and over it fills a space with pollen of flowers made into a paste with honey. She then covers this over with a ceiling of cemented sawdust, which also serves for the floor of the next chamber above it. This plate exhibits concentric rings, resembling somewhat the annual circles in the cross section of a tree, being worked by the patient artificer (and here her skill in joinery), bit by bit, from the circumference to the centre, all so united by the 
glue with which she is provided as to possess, when finished, the solidity of a single piece. Thus proceeding, she completes her ten or dozen cells, closing her main entrance by a barrier of the like material; and then, leaving the rest to Nature, that parent careful as herself, the process of development proceeds, and larva, pupa, and perfect bee make their appearance, each in due course, within their prepared nurseries. The lowest of these apartments, having liad laid within it the first egg, is the first, of course, to have a living tenant. How, when arrived at maturity before his junior and superincumbent brothers, is this winged apian to issue forth? He possesses in his jaws the trenchant tool, an heir-loom in his family; but air and use are requisite to give it edge and hardness : it will cut through his sawdust floor, but not through surrounding wood. But see within the latter, at the bottom of the cells, "a lateral opening," bored with prospective foresight by the parent "carpenter" to meet this very exigency.

Who has not heard or read of the rock-hewn temples of the East? of the far-famed cave of Elephanta,-that masterpiece of excavated architecture,-with its pillars and pilasters, its statues, its relievos of gigantic bulk, cut, all, out of the living stone (when, who knows?) by that dwarf in comparison of these his works, that ephemera in comparison with their duration, Man? But there are insects of another sort who have been working in ages as remote, and who work still, at excavated structures which, as measured with their own 
statures, are more gigantic by a thonsandfold than the sculptured Elephanta or the erected Edfou. Tiny architects are these, to whom bees and wasps are veritable giants; and yet their excavated dwellings, chiselled not indeed in stone, but wood,- - not in the heart of rocks, but in the heart of oaks,will occupy sometimes the whole interior of a massive tree. These also are "carpenters" - carpenter ants, their craft headed by the jetty emmet.* Their entire structures are, of course, too bulky for transportation to this our musenm gallery; but here, in some several fragments, we may look upon their "walls, their galleries separated by partitions with oval apertures or door-ways, their pillars, arches, columns, and arcades;" all wrought with wondrons lightness and delicacy, and all dyed of a dark, bordering on a blackish hue, how produced would seem uncertain, but peculiar to the excavations of these jet-black labourers-not the only ones which cut their sculptured cities in the trunks of trees.

But these " carpenters" must no longer detain us, or we shall want time to bestow a glance, even, upon their brother " Weavers." Upon the process of their manufacture we hardly ean, though many are here assembled and busy at their work. We may look, however, at a few collected specimens of their clerer spinning, as exhibited in a varicty of cocoons, from the looms chiefly of "Moths as Operatives" in their caterpillar estate. But before we examine the fabrics they have 
made, let us learn a little of the apparatus wherewith they make them. We can none of us have watched a silk-worm, or other caterpillar, at its work, without perceiving that its instrument of operation is seated very near its mouth, which may often, indeed, have been mistaken for it. The line, however, issues, as wire from a wire-drawer, from a distinct tube, or, more properly, two tubes united into one just before their termination, and proceeding from a pair of bags-bags of liquid silk-long and convoluted, placed on either side the caterpillar, each narrowing as they meet, and finally uniting in the before-mentioned instrument, termed the "spinneret." We may look now at what the weaver, by its aid, is enabled to produce, and admire in this collection of cocoons the infinite variety of their several textures, all adjusted accurately, in solidity or lightness, to the requirements, as modified by season, duration, and locality, of the chrysalides they are destined to enclose.

Here we have them from a veil of delicate net-work to a covering thick and warm as cloth.

Some (as those of the silk-worm) are of pure silk, mingled in others, in various proportions, with baser materials, such as hairs from the weaver's own body, particles of wood, bark, or earth; while a few are distinguished by partaking largely of animal secretions, widely different from silk, such as (in the lacquey) a powder resembling brimstone, and (in the oak-egger) a calcareous substance not dissimilar to the crust 
of an egg. 'This cocoon of the Hawthom Saw-fly, * exposed with its occupant all through the winter upon leafless hedges, is composed of a material tough as leather, but much harder (also an animal secretion). Here is an empty one with a curious lid set open as for the exit of the perfect fly, which, furnished with an adapted tool for the cutting of this singular trap-door, never fails in its circular excision to leace entire just such a portion as serves for an attachment and a hinge.

In our survey here of the mechanisms and the manufactures of insect weavers, we can hardly ovcrlook entirely the instrument by whose mechanic aid the hairy-legged Araches of house and garden ply their art of ensnarement. Their lines, though as fine, are (as their purposes require) infinitely stronger than those of a caterpillar; - and why? but because instead of being, as in the latter, composed of two, each single thread is made of united thousands of (to the eye) invisible and almost inconceivable fineness.

This compound thread requires for its production a compound instrument; thus the spinneret of the spider is much less simple than that of the caterpillar. We might suppose it by careful scrutiny of the unaided eye to consist of five several tubes, of which the prominent ends or orifices appear arranged in star-like form, surrounded by a circle. But only let us look at the same object as displayed here by a powerful mi- 
croscope, and we discern clearly that each of these spinnerets are studded by bristle-like points, called "spinnerules," to the number of about a thousand, from every one of which proceed, in spinning, as many threads, making in all five times that number, all united into one single line at a short distance from the spinnerets. The reservoirs of these spider weavers for their liquid silk consist of four principal and many minute vessels thence proceeding.

With a look at one other fabric, we must take leave for the present of insect manufactures.

This greyish-white substance is paper,-a paper strong, smooth, and durable, such as, if in sheets of size sufficient, we might even now be writing on. It is composed of vegetable fibres, reduced to a pulp, united by size or glue, and spread out into thin leaf. It is wrought by an artificer, who adopts a process precisely similar to that employed by those among us of the same occupation, only with more invariable success and skill.

What may be the name of this clever paper-maker? This specimen of work nearly discloses it. It is an aggregated collection of hexagonal cells, in all but material resembling a honeycomb; and a comb it is, a portion of one taken from the nest of a common wasp. $\mathrm{He}^{*}$ who first found out, after twenty years of vain experiment, that paper, and nothing else, is the substance of which such structures are composed, describes, on 
observation, the progress of its composition. He saw on his window-frame a large wasp-a mother wasp of the social or common species - an individual such as is often to be seen, in spring especially, on posts and rails and palings, busily employed, as his was, in gnawing into the wood. He saw her detach a bundle of fibres, not to swallow but to collect into a mass with her feet, and then, having caught her, he found these fibres to be thin as a hair and about the tenth of an inch long, not yet either moistened with gluten or rolled into a ball. 'These, as he discovered, were subsequent operations; and when assiduously performed, the accomplished paper-maker had only to spread out her sheets and employ them for their designed purposes, the lining of her nest and the construction of her cells.

But this, our insect paper-maker, with all her skill, is beaten hollow in her craft by a foreign artizan, a wasp of Cayenne, who makes a water-proof tree-suspended nest of card or pasteboard, "so smooth, so strong, so uniform in its texture, and so white, that the most skilful manufacturer might be proud of the work." Here-a gem of our collection-is one of these superlative specimens of papeterie, the last we can now examine of insect manufacture.

Ladies and Gentlemen,-The bell rings to announce the exhibition of objects in our powerful microscope. Those selected for to-day's observation are the tools made use of in production (with many more) of the structures and fabrics we 
have just been viewing, together with insect weapons of attack and self-defence. Wonderful alike for its simplicity and the manifold uses which it is made to serve, here is the double pickaxe, each blade toothed on the inner edge, acting thus all the better as a fast-holding pair of forceps, as well as a cutting chisel. This, the compound tool, only slightly varied with different possessors, is the only tool of the "wasp mason, carpenter, and paper-maker." A pair of wasp mandibles or jaws constitutes the instrument now before us. * A hard horny substance is the material of which this and nearly all insect tools are constructed.

A saw is the implement which next presents itself,- - a tool much resembling, only more complicated than that of our own carpenters: we may call it rather a pair of saws, or a compound saw, when in use working simultaneously at one cut. The instruments are so exceeding fine and delicate as to need support, and we see accordingly that their backs are set within a groove. The teeth, instead of being simple, are denticulated with others cut more finely, which confers on this tool the additional properties of a rasp or file.*

What are its uses and by whom employed? Its purpose is to cut grooves in the branches of trees and shrubs for reception and protection of insect eggs; and the insect by whom the grooves are cut is a maternal saw-fly - a very common four-winged fly, usually black and yellow or brown, of which 
all the species, which are many, are, in their first stage as caterpillars, distinguished from those of butterflies and moths by their many feet-from sixteen to twenty-eight. By these supported, they hang usually on the leaf which they are consuming, with the hinder part of their bodies rolled up in a spiral coil. The gooseberry, the currant, the rose, the willow, the turnip, and the wheat-plant, are foremost among the victims of their extensive depredations.

Here is another tool of surpassing nicety, lodged in a closelyfitting sheath, from which, on slight pressure, it is seen protruding. It is large enough for partial examination even by the naked eye, and, when thus viewed, appears a spike of equal thickness, except at the point, where it is broader and angular, and on both sides indented with teeth. Now let us behold it in the microscope. The teeth, strong and sharp, are, we can see now, about twelve in number on either side, and diminish in size as they approach the point. But what else reveals our magnifier? Why, it shows that the instrument which appeared simple to our naked sight is made up in reality of three distinct pieces (separable in their length), the two outer ones armed, as before described, with teeth, and called* "files," the central one pointed like a lancet, and not denticulate. The side pieces can be moved backwards and forwards, while the middle one remains stationary. $\dagger$

This curious implement, of which it has been said justly

* By Réaumur.

$\uparrow$ See Vignette. 
that " no human workman could construct one so small, fine, exquisitely polished, and fitting so exactly," is a tool used for a purpose something similar to the last, that, namely, of cutting grooves of a particular description in woody branches for reception of insect eggs. The carpenter, or carpentress, which owns it, is the female Tree-hopper, or Cicada, who thus cuts the branches, while her mate "bursts the very shrubs" by his shrilly music. Our "cuckoo-spit" is an allied insect; but in England has been found as yet only one Cicada,* which resembles that possessed of this admirable tool. In the large dead specimens, now easily procurable from China, its examination is not difficult.

Our next more simple instrument is an awl, or piercer, which issues from a sheath, in form of a curved needle. It is the piercing ovipositor-the wonder-working wand of a fairy Gall-fly,-and, though a great deal longer than the insect's body, is, by a mechanical contrivance, nicely adapted to it. Its base near the tail, it follows the bend of the back, "makes a turn at the breast, and then, following the curve of the belly, appears again near where it originates."

We have here another borer, or brad-awl, defended by a sheath, which opens lengthwise, like a pair of compasses. 'The awl itself is single, nearly three inches long, and terminates, not in a simple, but a serrated point. This is the instrument of that large common ichneumon, $\dagger$ which, for deposit of her

* C. Anglica, found by Mr. Dale, afterwards by Curtis, in the New Forest.

† Timpla manifestator. 
eggs, pierces through the clay defences of a "mason" wasp's nest. Those of other species are long or short, strong or weak, in accordance with the substances they are meant to penetrate.

In the above objects we have examined a few only of the tools possessed by insects; and a few of their weapons will follow in our magnifying show.

Here, as seen in the microscope, is a small needle,-a needle of human manufacture. Its point appears " above a quarter of an inch in breadth, not round nor flat, but irregular and unequal; and the surface, so smooth and bright to the naked eye, seems full of ruggedness, holes, and scratches, like that of a rough iron bar."**

Beside this clumsy piece of workmanship is now introduced another, by an infinitely more skilful hand, which exhibits " a polish most amazingly beautiful, without the least flaw, blemish, or inequality, and ending in a point too fine to be visible." $\dagger$ This we might suppose to be our insect weapon-a natural as contrasted with an artificial needle; but no such thing; it is not the weapon, only the weapon's sheath. This opens longitudinally; and now we discover what it enclosed, viz., two darts, distinctly separate even to the base. We ean see further, that these darts are each of them armed with ten saw-like teeth, such as occasion the instrument, sheath and all, to remain frequently within the substance wherein it may be plunged. In truth, this is a formidable-looking tool of tor-

* Hooke's 'Micrographia.'

† Hooke, 
ment; but poisonal so comes in aid of its lacerating power,liquid poison, contained in an attached bag, from which, on pressure by a mechanical contrivance, it is ejected into the wound at the moment of its infliction. This deadly weapon is a bee's sting.

We are shown next the blood-drawing stiletto of a gnat. We inspect it with an unaided eye. It seems to us a needle, solid, pointed, fine as a hair. We see it in the microscope, and in lieu of a simple needle, we behold a compound of several pieces, some of which are barbed. These are the piercers, while the sheath which encloses them is the sucker, which completes the apparatus.*

But enough of these wounding weapons; - and, hark! the orchestra is beginning. We hear a mingled strain of sounds harmonious proceeding from stringed instruments and drums; insect instruments of mechanism no less curious and complete than those we have been lately inspecting. We cannot now look into their structure, but while our ears are being regaled by their music, not all of harmonious character, but replete with pleasant associations, we must employ our eyes on the concluding exhibition of this our gallery. All is ready; not exactly for " dissolving views," but for emerging pictures.

Now, ladies and gentlemen, we are seated. The canvas, a

* See, for a more detailed description of most of the above-mentioned objects, the works of Réaumur, Swammerdam, Burmeister, and the volumes of 'Insect Architecture' and 'Miscellanies.' 
piece of small dimensions, hangs before us. "What! (do you exclaim) what is there to see in that? a dirt-coloured, patternless fragment of damp-looking rag, or paper-or what we know not-full of folds and creases!" Have patience, friends, for a few minutes only, and that patience will be recompensed. Now, sec there! The canras, as if by magic, grows larger by at least five times, as if stretched upon a framework ; its folds and creases gradually disappear; upon its surface, hitherto a clouded dirty white, appears the dawning of varied hucs and forms. Patches become visible of dingy red, and white, and blue, and brown, and black, and buff, mingled confusedly as on a much-used painter's palette; but see now, with each moment, how these masses gather clearness. Spots, plain and eye-like, bars, rich shadings, and pencilled tracery, come forward and arrange themselves in regular form and order; each colour assumes fresh brilliancy; and here and there a glancing of metallic lustre adds a finish to the whole. One picture is complete! But what do we see now? The beautiful tableau on which we have been looking would seem after all to have been but the reverse of a yet richer painting-the reverse, more properly, of one leaf, as of a double screen. Now it is unfolded, and we have before us, not one, but a pair of resembling pictures, wherein masses of glowing scarlet and purest white, the two prevailing colours, are contrasted brilliantly by a ground intensely black, as of blackest velvet, bestrewn partially with particles as of glittering gold-dust. 
Our tableau-truly a tableau vivant-is that presented by the wings of a butterfly-those of the "Admirable" (Atalanta), as they grow in size and put on their colours before the eve fortunate enough to see the process of their first expansion.

A dozen more such tableaux successively present themselves, each, like the last, emerging, and displaying endless variations in design, in touch, in style, in colouring. Some are light and airy as a day of spring; some, gay as summer; some, rich and glowing as the autumn landscape; some, grave and sombre as the wintry forest, but, like that, presenting graceful forms and delicate tracery, brown and branching.

Now, with the orchestra's concluding strain, the last picture has emerged, a curtain drops, and the gallery is about to close.

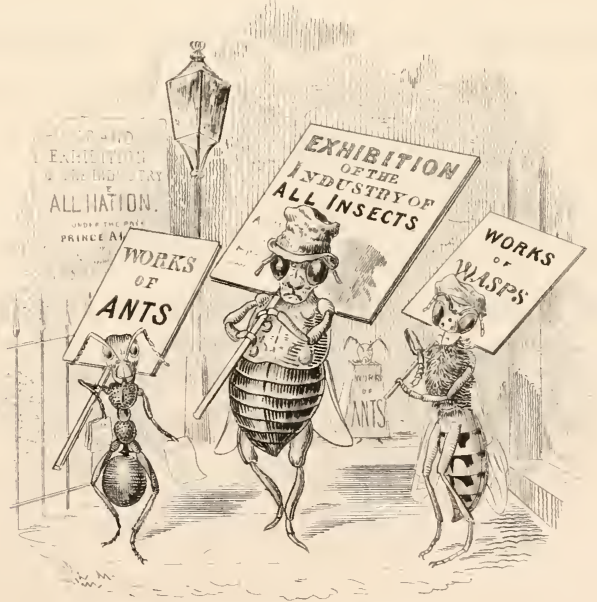

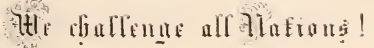




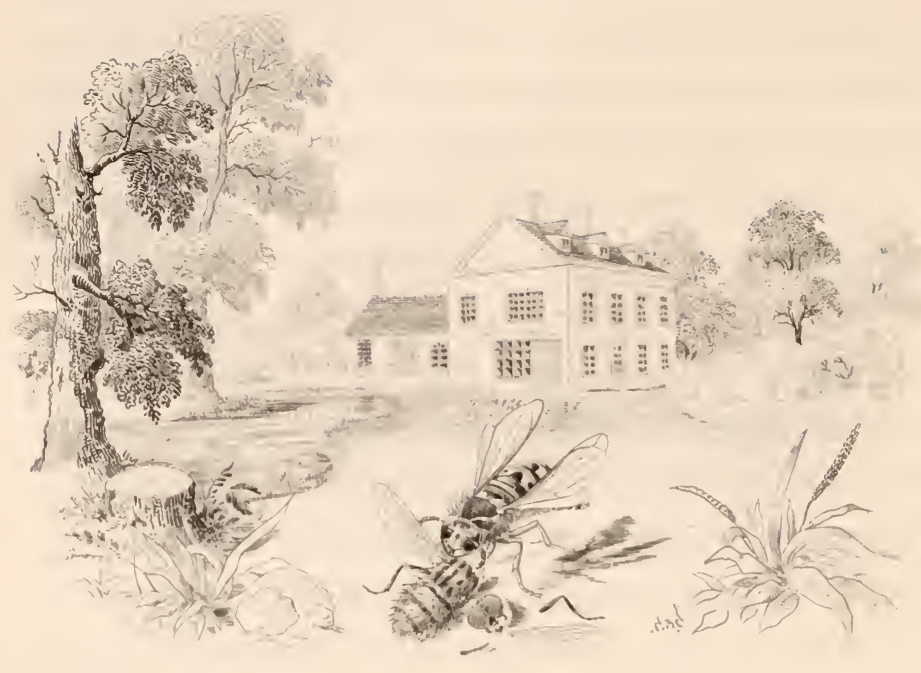

TITO THINGS OF DIFFICLLT DEFINITION.

"Reason serves when pressed,

But honest Instinct comes a volunteer."

Nature is now daily locking up from observation, although in no spirit of a miser, more and more of her vegetable treasure, and therewith has hidden from our view nearly all of those insect myriads which filled the summer air. This dearth comparatively of outward objects of interest inclines, or in a measure drives, us to seek for others of a kind. not palpable to sight; and as the decline of life, with the failure of its active energies, affords greater leisure, and should excite increased desire to 
look within ourselves, so the decline of the year gives time, and naturally leads us to inquire into the nature of those inward springs by which are set in motion all the outward activities which have formed, hitherto, the chief objects of our notice.

By the animating principle of the insect world, we do not, of course, mean that of mere vitality, common alike to animal and plant, but that endowment of perceptive and apparently judging mind which directs the former in its various operations.-Instinct shall we call it? Reason? or a combination of both? This is a question which, according to the observation of a distinguished naturalist, can never be resolved with absolute certainty, except by the person who should be permitted to reside some time within the head of an animal, without assuming its identity; or hardly even by a person so situated, seeing how imperfectly we can define, and discriminate between, our own varied or compound springs of action.

That those of all animals, insects included, are compound also, made up of instinctive together with other principles, is a notion to which, however, we must incline, in common with many observers of better judgment than our own. Others,* indeed, to whom we must certainly concede the same superiority, assign to animals instinct only, making of them mere machines, mere instruments adapted to the performance of a certain number of actions, just as a barrel-organ is constructed to play a certain number of tunes; - - a theory, this, hardly con- 
sistent with the new and clever expedients to which insects and other animal agents so frequently resort, under unusual circumstances, which their ordinary modes of proceeding are not calculated to meet. No one, on the other hand, ever, we suppose, attempted to assert that the animal mind is one of pure rationality. Assuming, then, that it is composed of instinct and of a something else, which, if it be not REAsox, is very difficult to distinguish from it, let us look, first, a little closer into the nature of the instinctive principle itself; make then a brief selection from such common habitudes among insects as would seem most clearly of instinctive character ; and point out, lastly, certain other of their casual performances such as would seem prompted by reason, or its semblance, when "pressed" by circumstance.

Perhaps the best definition of insect and other animal instincts is that given by Kirby, who considers them as "unknown faculties, implanted in their constitution by their Creator, by which, independent of instruction, observation, or experience, and without a knowledge of the end in view, they are impelled to the performance of certain actions tending to the well-being of the individual and preservation of the species."

Such certainly would instinct seem to be; but of how it thus impels, of the mode in which it works, though a great deal has been conjectured, little enough is known. Some have resolved this directing power into mere sensitivity, or an impulse to do certain things for the sensual pleasure they afford. It 
has been said, nearly to the same effect, that Instinct works by the love of self-an axiom of which, however, the hen gives a strange illustration when (as has been known) she sits herself into an atrophy over her eggs, or when she points out, and leaves for her brood, the grain which appetite bids her swallow. Scarcely even can the garden white butterfly be supposed to gratify her senses when she forsakes the sweets of the flower-border to deposit her eggs upon a cabbage. And if these, with a hundred other acts of instinctive performance, can hardly be assignable to mere corporeal pleasure, still less, happily, is there ground for adopting the most absurd and most abhorrent theory of Mylius, who would make sensation, not pleasurable but painful, the mainspring of all instinctive actions, who would persuade us that the weaving caterpillar exudes and twists her silk cocoon, not in a fit of industry, but in " a fit of the colic."

Instinct is supposed by Addison to be an immediate and constant impulse of the Deity, but the mistakes into which it sometimes falls have been urged against the correctness of such a notion. Err, however, as it occasionally does, this guiding power is usually so regular in its operations, and would seem, moreover, to exercise such strict control, that did we allow to animals no other mental principle, we should be forced to consider them, with Descartes and others, as machines and nothing more. That they all deserve to be regarded in a higher light, there are certain of their actions which go VOL. III. 
far to prove; but for the present setting these aside, let us review briefly a few of the workings, in the insect world, of that mysterious faculty we have been considering, that mental mechanism of wondrous adaptation of which the springs would seem hidden from all save their Great Artificer, or, possibly, some inquiring spirits permitted to see further than ourselves into the secrets of creation.

Through Tustinct, that endowment which is usually as perfect in the insect's creeping infancy as in its soaring adolescence, all caterpillars are directed to find, or more properly to appropriate, the food instinctirely provided by the mother's instinct, while some, even before that provision is attacked or cared for, are bidden by the same imperative power to shape and clothe themselves with garments made generally out of the same material as that to be employed for food. Of this we have seen examples in the clothes-moth in its state of infancy, with others of the same tribe ('Tineida) which make to themselves cases, or moveable tents (whence they are called tentmakers), out of leaves, bark, and other substances.

The weaving, most ingeniously, of variously-formed cocoons, more or less solid, according usually to the period of their occupation,-the suspending themselves no less cleverly, and in places of security, for the process of transformation, are performances no less admirable of the caterpillar crew; and the instinct which directed them, dormant for awhile, witl other faculties, in the chrysalis, wakes again in the winged insect. 
Thereby directed, the moth or butterfly, perhaps guided also by her taste and smell, repairs directly to the flowers whereon she loves most to take her pleasure; and then, in opposition to those very senses, proceeds, at Instinct's bidding, to the flowerless shrub or vegetable, for deposit of her eggs on the leaves best suited to support her unthought-of progeny.

With bees, ants, and other social insects, Instinct would not appear, as with the Lepidoptera, to spring from the egg in full maturity, not at least with the active and varied powers afterwards acquired. In bee grubhood, also in that of wasps and ants, the instincts of imbibing nourishment and of spinning their cocoons would seem the only ones in activity, the place of all others being supplied by that watchful assiduity, also instinctive, with which the labourers of the hive or ant-hill tend upon the young of their communities. But no sooner does the bee attain to maturity, than Instinct in full development, like the form over which it is to bear rule, impels the wings, untried, to carry their possessor by the shortest cut to the flowery fields of her earliest labour; then reconducts her to her straw-built home as unerringly as though she, the tyro gatherer, were the most veteran collector of the hive. With this, the bee's first expedition, memory can have nought to do ; if it had, the feat in question could no longer be attributable to instinct-instinct, it would seem, of a peculiar character; a wondrous tact, an occult faculty or sense, of which we, as not possessing, can form no conception. By animals 
of almost every other kind it is exhibited on occasion. It reconducts the salmon, after a long sea-voyage, to the spot where it has once spawned; it guides the returning flight of the carrier-pigeon and the bird of passage; and that this pilot sense is the gift also of various quadrupeds, is attested sufficiently by facts, of which almost every individual could vouch for one, relative to some canine or feline favourite.

But returning to bees, it is to instinct in its operative form that these winged artificers are indebted for the plan of their "waxen palaces" and hexagonal apartments, which for adaptation, for saving at once of material and of space, could not be improved on by mathematic calculation. The grand proportion, in short, of all labours and proceedings in the insect world, would scem clearly referable to Instinct, a lamp of Divine light which, shining with peculiar lustre in this department of the animal kingdom, decreases, though still powerful, amongst birds and quadrupeds, and dwindles in man, in him, as observed by Colcridge, growing proportionately " dimmer, as his reason shines more bright."

But does reason shine alone for man of all the inhabitants of earth? Men there are, not perhaps of those who best cultivate this most improveable possession, who would yet for themselves and kind claim its exclusive monopoly. Such as these must grudge of course to the gigantic elephant even the half justice commonly awarded him in the epithet of "halfreasoning" animal; and looking on him merely as an enormous 
clock, of which the clumsy machinery is worked alone by instinct, what other can they do than regard as a tiny watch that insect miracle yclept an ant? None acquainted at all with the chronicles of elephantine performance, can be at a loss for facts, not isolated, entirely at rariance with the idea of making of the elephant a mere monster machine; and as for the ant, the following relation,* with a thousand more, would read strangely of a mechanic agent:-

"I saw an ant pulling with his mouth a piece of wood. The rest were busy in their own way; but wheu he came to an ascent, and the load became too much for him, three others came immediately behind, pushed it up to level ground, and then left him. The end he pulled was the smallest, and, as he drew it between two things, it stuck there. After several fruitless efforts, he went behind, pulled it back, and turned it round."

Proceedings such as these accord certainly much more closely with the opinion of the enlightened and pious Sharon Turner (by whom the fact is quoted), that "the actions and habits of the insect world display the sane kiud of animal mind [allowed by the same writer to be judging mind] and feeling which birds and quadrupeds exhibit. If there be a difference, it is not to the disadvantage of insects, for ants, bees, and wasps, and especially the smallest of these, ants, do things, and exercise sensibilities, and combine for purposes, and

* From the 'Imperial Magazine.' 
achieve ends, that bring thein nearer to mankind than any other class of animated nature." $\dagger$

We insect men may not relish, perhaps, or care to observe, this approximation towards ourselves, of men-like insects. We would rather, perhaps, make the most of the inferential argument, that because insects proper have avowedly a very large share of instinct, they have therefore no reason at all. We might as well infer of ourselves, contrary to facts, that because we may have a large share of reason we are utterly devoid of instinct.

But apart from all jealous or all careless want of notice of insect ways, and our imperfect appreciation, consequently, of their mental cndowments, our means of judging them are, in truth, but slight and superficial. From their minute size, their brevity of existence, and many of their habits, the members of the insect world are precluded from anything like that reciprocal intercourse with man, which, in the case of the larger animals, tends to throw so much light upon their natures, and to develope their qualities of intellect and affection. What has been said of these lattert may therefore be urged with double force in regard to insects. - "It ought always to be remembered that brutes have more reason than they can show, from their want of words, from our inattention, and from our ignorance of the import of those symbols which they use in giving intimations to one another and to us."

* 'Sacred History of the World,' vol. iii.

† By Dr. Hartley. 
Who of us shall say, darkling as we are, that because the lamp of instinct is, for all their common wants and purposes, the guiding light of insects, that they are not permitted to possess in reserve, and to employ in special exigencies, some assisting tapers kindled at that more exalted luminary, Reason? That thus it is, the observations of those who know most of their economy go far to prove; - -so far, that if we deny to them a certain measure of rational judgment, we must do the same to every visible denizen of earth which wears not the human form. Some insect actions, it is true, which would seem on consideration referable solely to instinct, so very much resemble such as are prompted among ourselves, by reason acting on experience, that were not, with the insect agent, that experience known to be wanting, we should conclude that from reason they must emanate.

Of this description is a practice common amongst some of the solitary wasps, which are accustomed to provision their tunnelled nests with a supply of living caterpillars as food for their young. If these caterpillars were stung to death before deposit, they would soon be in no state of proper preservation for their destined consumers, and if consigned unlurt to the sepulchral larder, they would disturb the quiet, perhaps destroy the existence, of its infant inmates. To meet these contingencies, what does the maternal purveyor but inflict on her soft-bodied victims not a mortal, but a disabling wound, which keeps them in their coil, each waiting passively its turn to be despatched. 
This proceeding of Mother Wasp reminds us of the trick of Maître Hibou, in La Fontaine's Fable of 'Les Souris et le Chat-huant,' which, according to an appended note, is no fablc at all, only a fabulized fact.* The story, familiar probably to many of our readers, runs briefly thus:- "An owl had made his palace in the hollow of an old fir-tree. The tree was felled, and in its cavity what should be discovered but a brood of mice as fat as butter, but without a single foot left amongst them? The bird of wisdom had discovered, it would seem, that little quadrupeds could manage to give the slip occasionally to winged bipeds, and had therefore employed his beak to annihilate the trotters of the furry brond. With a foresight reaching further still, eveu to the length of what we exclusively call human, he had there fattened them on pilfered grain, to keep them in good condition for consumption at leisure and at pleasure. Hereon exclaims our poet, as well he may, admitting his fable to be fable but in name :-

\section{"Puis, qu'un Cartésien s'obstine}

A traiter ce hibou de montre et de machine!

Quelle lui pouvoit donner

Le conseil de tronquer un peuple mis en mue?

Si ce n'est pas là raisonner

La raison m'est chose inconnue."

It is not so much to draw a parallel as to point out a difference between the owl, as mutilator of his mice, and the wasp,

* "Ceei n'est point une fable; et la chose, quoique merveilleuse et presque inerọable, est véritablement arrivée."-Author's note. 
as disabler of her caterpillars, that we have quoted the above relation, assuming it, as affirmed, to be plus vrai que vraisemblable. The owl's measure of precaution was one which owls do not usually adopt, and if, as this would imply, resorted to on experience, it proved him most undoubtedly a reasoning owl. The wasp, in a proceeding somewhat similar, only does that which all wasps of the same species have done before and will do after her, and that on the very first occasion which calls for their maternal care in the furnishing of their nursery larders. In this, therefore, we can only look upon her as a wasp instinct-guided.

The practice of ants to rear aphides for the future consumption of the sweets they furnish, bears equally the character of instinctive prescience.

Other operations in the insect world which can scarcely be referred to the promptings of reason, are yet made greatly to resemble those of reasoning agents, by their occasional deviation from the usual track or mode of performance. This has been instanced in the blow-fly, when, through instinct, guided, misled rather, by her sense of smell, she commits her eggs to the inhospitable keeping of fetid stapelias, or of paper containing meat.

Instinct can also on occasion vary as well as err ; often displaying, among insects, its capability of accommodating itself, like reason, to circumstances. This is continually exemplified in the case of caterpillars, which, when confined to a box, will 
employ bits of paper and other chance materials in lieu of the grains of wood or earth with which nature is accustomed to supply them. Another instinctive operation varied to meet exigence is instanced by Réaumur, in the proceedings of a little elm tent-maker, whose tent or case of leaf-skin having been cut open at the side, was sewn up by its little occupant, instead of being supplied by a new one, as unvarying instinct would have prompted.

Endowed with instincts so subtle, fine, and pliant, what need, it may be asked, have insects to possess even a modicum of reason? That the gift is not useless or superfluous if given them, is to this sufficient answer, and that it is, would appear no unfounded supposition, judging from a variety of acts betokening an intelligence which, if not Reason's very self, bears its very image.

We have giren, elsewhere,* Dr. Darwin's often-quoted anecdote of the wasp and the dead fly, whose wings, when found on trial to be obstructive of its convenient transport, the wasp alighted to cut off. Kirby remarks on this relation, "Could any process of ratiocination be more perfect? Instinct might have taught it" (as we believe it usually does) "to cut off all the wings of all flies previously to flying; but here it attempted to fly with the wings on, and was impeded by a certain cause, discovered what that cause was, and alighted to remove it." Did not the discovery of this cause imply also 
memory, and a gain of knowledge from experience, by which alone the wasp could have been taught, or reminded, that the wings of the fly were the impediments to his flight-have given him at least reason to suspect it from the greater facility with which he had transported bodies that were wingless?

A trick, asserted by Huber to be on occasion resorted to by humble-bees for the purpose of extracting honey from flowers that are deeply tubular, has been adduced as another striking instance of the capability of insects to profit by experience. These humming honey-suckers usually extract the nectar from the natural opening at top of the bean and other tubular flowers; but when by the breadth of their shoulders forbidden entrance into this narrow passage, they drill a hole with their proboscis through the calyx right into the tube, and in this manner tap their luscious wine, while the less bulky Bacchanals of the same species quaff it in the ordinary way. It is inferred from this proceeding that the larger bees, having found on trial that they could not reach the nectar from the top, have recourse to a more ingenious method of getting to the bottom of the reservoir.

On the whole, it would appear that the intellectual light with which insects are endowed - be it instinct solely, or instinct aided by reason-exactly resembles in kind, while in many of its exhibitions it more than equals in degree, that bestowed on other animals, however we may incline, naturally, to assign immeasurable superiority to the intelligence softened 
by affection towards ourselves, which beams in the eye of a favorite dog, or speaks in the recognizing chirp of our petted bird.

Speaking of affections leads us to inquire about those of insects;-for affections they would seem most clearly to evince in their social relations and intercourse with one another.

Contrary to the axiom that "instinct works by the love of self," nothing can seem in the insect, as well as in the feathered fowl, to work more unselfishly than the instincts or affections of maternity. The earwig, as we have seen, imitates the brooding hen. The spicler will sacrifice her life to save her eggs from destruction. The solitary bee or wasp, after preparing her nest with infinite labour, collects for the provision of her offspring a supply of animal food unpalatable to herself. While anongst the insects termed social, such as common wasps, honey-bees, and ants, the same maternal principle, implanted not (with all) in the producing but in the working mothers, incites to efforts yet more surprising, of toil, of watchfulness, of self-sacrifice.

Nor is the love of offspring, or that resembling affection implanted in the general nurses of the hive or formicary, the ouly attachment of which insects seem susceptible. If all about them be instinctive we must allow them to have instinctive friendships, fellowships,-fellowships at least for mutual advantage and assistance,-fellowships such as are, of all others, most similar to those wrought and cemented under the guid- 
ance of reason. For the cultivation of such intercuurse there exists scarce a doubt, of their being provided with means of communicating their wants and wishes-a sort of dumb language (dumb, at Ieast, to our perception) of which their antennæe are supposed to be the principal organs.

It is not ours to boast ourselves of any talismanic gift, enabling us to " understand the steven" of parleying insects, as the Lady Canacé of birds, through the fabled virtue of her faëry ring; but we never watch the busy workers of the anthill, coming and going, stopping as they encounter, and laying their heads together, without being pretty certain that they are saying to each other a something quite as full, perhaps, of informing or of friendly significance as the "Fine day," or the "How do you do?" which forms the usual salutation of meeting mell.

We may often, too, perceive an ardent little labourer of the same race toiling at a burden-may be, a great dead bluebottle-may be, a fragment of wood five times bigger than herself. After repeated efforts, she finds her strength unequal to remove it, and then bethinks herself (for think she must) that two or three united forces, and several pairs of forceps, are better than one, and, acting on the thought, we see her approach another, or perhaps a. group of her comrades, conduct them to the spot where she left her load, and succeed by their assistance in its transport.

Similar instances of mutual assistance-occasionally, not uni- 
formly, required and rendered-are well authenticated, of the pellet-rolling and burying beetles.

On the borders of a path or roadway leading through Highgate wood towards Hornsey, are scattered several of the conical cities of the red or wood ants. These, in their comings and goings, are accustomed continually to cross the thoroughfare, whereon as continually many among them fall victims to the feet of the passers-by. The intelligence of the survivors extends not certainly to the length of making them take warning by the fate of their comrades; yet do they seem to observe and sympathize therein. We have repeatedly noticed them stopping, first one, then another, on discovering of a dead mutilated body, till a group of scveral is collected round it. Sometimes, after an apparent consultation, the individuals separate, leaving the remains where found; at others, singly or together they attempt and accomplish their removal.

We are assured by Huber, of the same extraordinary creatures, that they have shown indubitable signs of mutual re. cognition, greeting each other according to their peculiar fashion, after a separation of four montlss, a portion of their little lives equivalent at least to twenty years out of our threescore and ten. To believe this, is at once to allow them a proportionate share of combined affection and memory.*

That with relation to each other, the instincts or the affec-

* See, for an instance of evident communication between insects, "A Love among the Roses," vol. ii. 
tions of insects are not, then, as has been imagined, wholly selfish,-that, however circumscribed their sphere, they yet move in a circle beyond the central point of sensual gratification or self-preservation, is scarcely, we think, a matter to be doubted; but how far the mental principles of these little creatures, like those of the larger animals, can communicate with, or may in any degree be susceptible of, influences from the " master mind" of man, is a question which most people would deride rather than attempt to answer or consider.

And yet, perhaps its absurdity may only lie on the surface. Let us only interpret literally the scriptural assertion, that " every kind of beasts, and of birds, and of serpents, and of things in the sea is tamed and hath been tamed of mankind,"** and we shall have no reason to think but that insects, endowed as we have seen with an intelligence exactly resembling that of other animals, should be (as far as regards their mental constitution) equally susceptible of our influence.

This may only have failed to be apparent from their minute size, which not only causes us to look so contemptuously down on them, but which, from the seemingly confined sphere of their senses' exercise, seems to prevent them from looking up to us-objects, in our comparative bulk, raised apparently quite beyond their perception and cognizance ; while the usually brief space of their allotted existence opposes another obstacle to anything resembling what we may call our educational influence.

$$
\text { * Epist. of St. James, ch. iii. v. } 7 .
$$


Admitting, therefore, that insect intelligence and affections may, from the above causes, be totally incapable of the least cultivation or development through agency of man, this is no proof of their inferiority to those of other animals. Instances, however, are not wanting of insects which, in spite of the above hindrances, have shown tokens of something bordering on domestication.

From the story of M. Pelisson's spider, which always descended for the meal wherewith he was accustomed to provide it, on hearing the sound of his flute, we may not infer, perhaps, that spiders in general are gifted (as would appear with the seal) with a soul for music. That particular spider, as well as his race, had probably only a taste for flies; but from the fact related, the inference is plainly deducible, that they are capable of receiving through their senses other impressions than those absolutely conducive to their support, and that they have in their minds a power of connection such as mere instinctive impulse neither requires nor exhibits.

Supposing the insect, in common with all other animal minds, to possess this extent of capability, we shall not laugh at Réaumur's expression of "the tamed moth," which sipped syrup off his finger, or doubt the relation of an English naturalist, who tells us of the humming-bird hawks, which, when on wing at their flowery repast, flew away frightened by his presence, till, tamed by custom, they learned to continue unalarmed the discussion of their delicate banquet. 
In speaking of animal natures in connection with our own, we cannot forbear extract of a few remarks bearing on the subject, by an American writer who has broached some new and intelligent ideas on the development of mind.

He considers (this, however, but in common with other thinkers) that " the character of all the lower orders of creation has suffered a change in consequence of that in the condition of man, the extent of which cannot be measured."

Relative to poetry, as the language of things, not words, he observes:-

"Everything which surrounds us is full of the utterance of one word completcly expressive of its nature. This word is its name, for God even now (could we but see it) is creating all things, and giving a name to every work of his love, in its perfect adaptation to that for which it is designed. But man has abused his power, and has become insensible to the real character of the brute creation, still more so to that of inanimate nature, because, in his selfishness, he is disposed to reduce them to slavery.

"We find the animal world either in a state of savage wildness or enslaved submission. It is possible, that as the character of man is changed they may attain a midway condition removed from both. As the mind of man acknowledges its dependence on the Divine Mind, brutes may add to their instinct submission to human reason, preserving an unbroken chain from our Father in heaven to the most inanimate parts 
of creation. * * * Everything will seem to be conscious of its use, and every man will become conscious of the use of everything."

This consciousness on the part of animals the writer supposes to be more than instinctive; but howerer we opine their instinct to be leavened now and likely to be further mixed with reason or some resembling ingredient, we can never imagine them to possess now, or be likely to acquire, one grain of such selfconsciousness as is indicated by the power of self-contemplation. This gift of capability to look inwards on ourselves, and, in so doing, of looking towards the Great Centre and Source of life and mind within us-this, with all the high improvabilities and moral responsibilities it involves, is what we must consider as the most palpable as well as the proudest of all distinctions between ourselves and the lower orders of creation. Far be it from us, then, to entertain or to propound the startling supposition that animals (however improvable or improved their natures) are likely ever to become moral agents.

We dare, nevertheless, to confess our leaning to, more properly our holding with, the opinion of a few (men intelligent and good), that it is not with the frames that enclose themwhether of elephant or emmet-that animal intelligence and affection are destined to perish. For the thousands of creatures, with natures formed for enjoyment, yet existing here only to groan under the cruel tyranny of man, we must and do contemplate a freer and happier state. 
And surely the idea is harmless, even if erroneous. Surely it is no profane infringement-as some, we believe, have viewed it -on our own blessed and brighter inheritance of immortality. Did our prospects of that rest alone on reasonings drawn from nature, we should be almost forced, as it seems to us, to admit our humble fellow-beings and fellow-sufferers to a share of our anticipated future.

But it is more in our province to illustrate than to argue. Let us show, in conclusion, how two poetic minds-Christian men of different countries and differing creeds-have thought and written on this our reconciling speculation. A canine favourite is the object whereon is made to hang with both poets their sentiment and belief; but allowing continued existence to the dog, we must not deny it (admitting the resemblance of their forms of mind) to the ant or to the bee. Thus, our Southey, on the death in old age, by drowning, of a faithful friend and companion of his youth :-

"But fare thee well! mine is no narrow creed, And He who gave thee being did not frame The mystery of life to be the sport Of merciless man! There is another world For all that live and move-a better one! Where the proud bipeds, who would fain confine Infinite Goodness to the little bounds Of their own charity, may envy thee."*

And thus, in substance, though in words which do but sorry justice to the beautiful lines of the original "Episode," does 
no meaner man than $\Lambda$ phonse de Lamartine address his real or imaginary favourite :-

"My dog! the difference between thee and me

Knows only our Creator;-only He

Can number the degrees in being's scale

Between thy instinetire lamp, ne'er known to fail,

And that less stearly light of brighter ray,

The soul which animates thy master's clay ;

And He alone cau tell by what fond tie,

My look thy life-my death, thy sign to dic.

Howe'er this be, the human heart bercaved,

In thy affection owns a boon received,

Nor e'er, fond creature, prostrate on the ground,

Could my foot spum thee or my accents wonnd!

No, never, never, my poor humble friend,

Conld I by act or word thy love offend !

Too mueh in thee I reverence that Power

Which formed us both for our appointed hour;

That hand which links, by a fraternal tie,

The meanest of IIs creatures with the high.

Oh, my poor Fido! when thy speaking face,

Upturned to mine, of words supplies the place;

When, sentry by my bed, the slightest moan

That breaks my troubled sleep disturbs thy own;

When noting in my heavy eye the care

That clouds my brow, thou scek'st its meaning there,

And then, as if to chase that care away,

My pendent hand dost gently guaw in play;

When, as in some clear mirror, I descry

My joys and griefs reflected in thine eyc,-

When tokens such as these thy reason speak

(Reason, which with thy love compared, is weak),

I cannot, will not, deem thee a deceiving

Illusive mockery of human feeling,-

A body organized, by fond caress

Warmed into seeming tenderness, -

A mere automaton, on which our love

Plays, as on puppets, when their wires we move. 
No! when that feeling quits thy glazing eye,

'Twill live in some blest world beyond the sky.

$\begin{array}{llll}* & * & * & * \\ * & * & * & * \\ * & * & * & *\end{array}$

No, God will never quench his spark divine,

Whether within some glorious orb it shine,

Or lighten up the spaniel's tender gaze,

Who leads his poor blind master through the maze

Of this dark world; and when that task is o'er,

Sleeps on his humble grave, to wake no more." *

* 'Jocelyn,' Episode par A. de Lamartine, tome ii. p. 155.

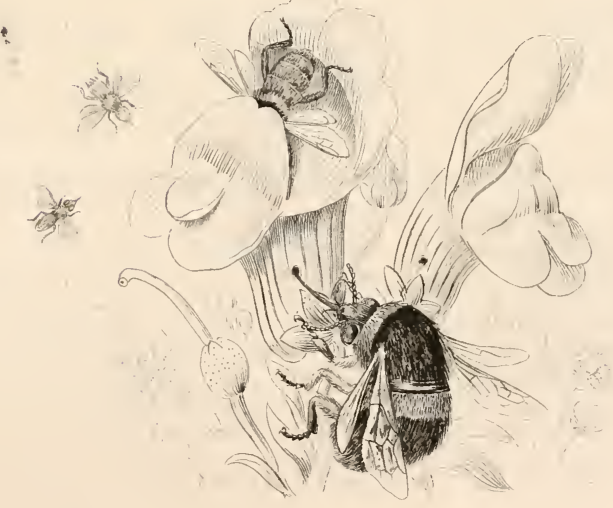

Hlore wang fhan one of geffing to flo botfou af a secref . 


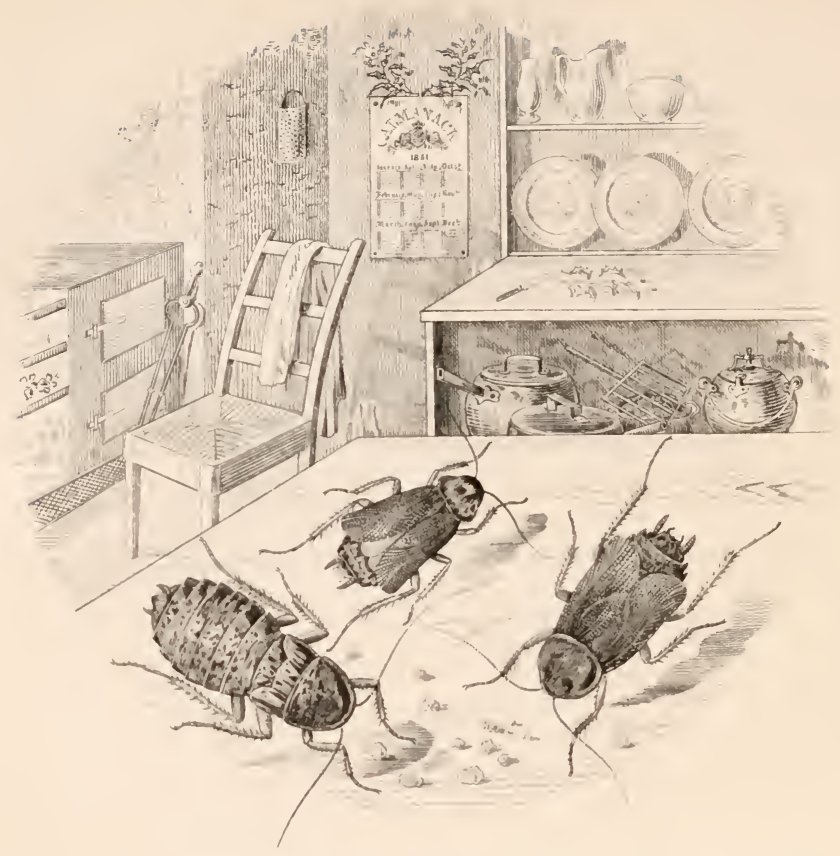

THE SPIRITS OF HEARTH AND HOME.-

\section{CHRISTMAS STORY.}

"Another year has nearly told its tale."-Мoxtgomery.

Oun circular path has brought us nearly to our place of starting. Another round of wonders is about to follow, in all the worlds of nature, upon that which has well-nigh run its course. A year ago (it seems but a day!) we were seeking a subject for an opening, and now we have to choose one for a concluding, essay. We look into our appropriated field, and, although for above the fiftieth time, can discern therein 
tracks by us untrodden, numerous objects still undescribed; but now, dear friends and companions of our sunny rambles and our fire-side musings, now that the time draws near for us to part, our heart opens towards you more personally, more tenderly, more confidingly, and, instead of seeking for a novel theme in some insect object or insect habitude not yet portrayed, we feel a yearning to end as we began, with our emblematic personality, the individual Acheta domestica, even with a concluding episode drawn from the annals of our childhood, a quiet chrysalidan period, yet active in development of all that constitutes our winged imago, our present self. Memory! painter of the past! let us invoke thee! Ah! but thou art too busy: we want but a single subject, and now, with a few touches of thy magic pencil, thou hast brought before us pictures enough of persons and of scenes to furnish an entire gallery,-pictures self-arranged, of which the clearest and the warmest-tinted are those most distant.

First, there is a landscape, half rural, half marine, of a village near the Kentish coast,-an old-fashioned quiet little village, with its heavy-headed chimneys appearing here and there amidst embowering elm-trees; more distant, the square spireless tower of the ancient church; and behind all, caught at intervals, the line of ocean, defined and dark, or mingled almost with the blue horizon.

Towards the centre of this wood-cradled nest, as a parent bird amidst her surrounding brood, and bearing towards the encir- 
cling group of cottages about the sane relative proportion, as well as something of the same relationship, there stands, in the foreground of our picture, an old quaint-looking residence, itself a cottage, but distinguished from the lesser and lowlier of the assemblage by its magnitude, its flight of steps ascending from the pathway to the garden gate, its surrounding shrubbery and tlanking fir-trees, its trellised porch and arched doorway, its casemented bay-windows, and its clustered chimneys, from whence (our landscape is a winter one) the smoke is ascending through the frosty air in sturdy upright columms, that tell, indisputably, of comfort and of cookery within. Three other pictures (family and domestic portraits) we nust take llown, next, from our memory-furnished gallery. All are of dwellers in the cottage just described, the principal residence, and eke the vicarage, of the village of $\mathrm{H}-$.

First, we have its reverend master, of build substantial and air unpretending as his abode, of middle age, middle stature, and mediocre features, a man altogether made up of middlings, except that he seems invested with a portion more than middling of indolent good liumour. Most easy vicar! dearly did we love thee; but only in proportion to thy claims upon our young affections. Thou wert our kind uncle, and, much more, scarcely less a father unto us thim to thine own only little laughter Lucy; and thou wert, moreover, our tutor, our earlicst instructor in much of raried knowledge,-truly more varied than profound. Thyself an entomologist (albeit of no 
zealous stamp) 'twas thou first set us on our hobby, and for' this alone we should revere and love thy memory.

Two humbler personages hang, in their portraitures, beside our uncle,-humble, yet withal of vast importance in his household, which, for several years, had been without a mistress.

One is the widower's housekeeper, the nurse of his little Lucy, and once his own, old Dolly-Dolly Dove-than whom no feathered parent of the dove-cot ever spread a wing more tenderly over her cherished nestlings. Her hair, white nearly as her full-bordered, high-crowned cap, and set in a few flat curls upon her smooth round forehead, tells something of her age; yet of winter, excepting in this single snowy vestige, few are the tokens that she bears about her, either in her plump, full figure, or in her ruddy, fair-skinned, blue-eyed, small-featured face, glowing in the light of warm kind-heartedness, as a flat Flemish landscape in the sunset of a summer's eve.

The other portrait, a striking pendant to the last in the way of contrast, as a shrunken pea-pod to a round ripe apple, as a blasted pine-tree to a "hospitable oak," as a dry walkingbranch caterpillar to a fat-bodied downy moth, is that which preresents the figure of Dolly's fellow-servant, our uncle's butler, valet, amanuensis, and librarian, eke our writingmaster (Lucy's and mine), the angular, bony, spindle-shanked, high-shouldered, hard-featured, hard-minded, if not exactly hard-hearted, Caleb Caligraph, who could never from his cradle lave looked young, and could never to his grave have appeared 
absolutely old. That straight rigid back has not bent beneath the weight of years-that wiry inky hair shows no besprinkling of grey-that lengthy visage, complexioned always like the sear and yellow leaf, exhibits only in its reddened purplish tip, a frosty touch of winter ; and as for wintry furrows, though the graver of time has here, doubtless, deepened them, they must all, Caleb, even in thy youth, have been traced visibly, just as in pencil the lines and letters thou wert accustomed to mark out for the guidance of us, thy pupils in the caligraphic art.

Now, last of our pictures, comes an interior, a scene by firelight within the cottage parsonage depicted in our first. Here is the large low kitchen, opening out of the large low hall, with its oaken rafters apt for the double duty of supporting superincumbent chambers and dependent hams; its dresser of like solidity, only of more fair complexion, and displaying on its shelves a bright array of blue-edged platters and polished pewters, both shining in cold disdainful rivalry against the ruddy coppers underneath; the whole illuminated by the glare of a Vesuvian mountain of wood-crowned coal, glowing at bottom, blazing at top, crackling and spluttering, rejoicing, as it would seem, within its ample range, that its culinary labours, for the day, are ended.

On a large deal table before the fire, a match with the dresser in whiteness and solidity, is placed a tea-board with all appurtenances for tea, and for a tea-drinking of no common 
kitchen order, to judge by the appearance of a silver creampot, a bason of white sugar, and a large plum-cake in all the integrity of its rotund form.

Our interior is not entirely a picture of still life. Seated, one on a low stool, the other on a wooden chair beside the fire, are two children-a little white-frocked girl of perhaps nine or ten, fair, and looking fragile as a flower, and a boy some three years older, and by his garb seeming, like herself, a visitor only to the kitchen. The girl is as at ChristmasChristmas fifty years ago-appeared our little cousin Lucy; the boy is none other than ourself, when not the cricket, brown and desiccate, but the verdant grasshopper (emblem of youth and happiness) was our most befitting representative.

It the period when the above scenes and persons were invested with reality and life, the 23rd of December used to be a red-letter day in our then short calendar. It was that on which our uncle was accustomed to entertain a party of old college friends; and we and our cousin, our company superfluous in the parlour, were permitted to bestow it in the kitchen, there to take tea with Dolly Dove and Caleb. The former, indeed, as became her station in the minister's family, was possessor of a peculiar nest, well lined and comfortable, known as the housekeeper's room-in part, also, Lucy's nursery - with its lofty linen-press and deep-shelved closets, into whose sweet profundities we had often, with the flies, contrived to penetrate; but on the anniversary in question, the suborli. 
nates of the establishment, stable-boy, house- and cook-maid, were accustomed, in the evening, to have a holiday with village friends, under which circumstances Mistress Dove and Master Caleb preferred the entertainment of us their guests in the kitchen.

In the kitchen, then, behold us, by firelight,-Lucy and I, and a large white cat. My uncle's dimner had been some time over; he and his two or three college chums were deep in old port and youthful reminiscences. Dolly, having first crowned the fire with an extra log, and set the tea-table, was upstairs, preparing herself to do its honours, while Caleb, who had something to do with everything, had gone out to see that the visitors' horses were properly supped up; and so it was, that I and my little cousin and the large white cat were left with none other visible company.

It was a tempestuous winter's evening :- the sleety rain came every now and then pattering against the casement, and falling in hissing drops upon the thirsty flames; and when the showers remitted of their battering violence, we only heard more plainly the howl of the east wind in the tops of the old fir-trees round the house, and the ereaking of a rusty weathercock on an adjacent dove-cot, with the sharp gallop of a hurried horse upon the hard high road, followed by the angry bark of our house-dog Keeper; but of all these varied sounds, nearest and most distinct, and diverting speedily our attention from them all, was the chirp of a cricket from between the bricks of the 
glowing hearth. This cricket was no new acquaintance. He was, as it seemed, the sole survivor or the only lingerer of a once numerous colony, which used to locate in the kitclien fire-place, under Mrs. Dove's especial patronage; or, to speak more correctly,--more in accordance, certainly, with Dolly's feelings, - we should have said rather that she and the domestic labours she performed or superintended had flourished under theirs. The chirpers she had always held in superstitious love and veneration. They were her household gods, her Lares and Penates, the conservators, in her simple estimation, of the fortunes of her master's house. In these it is certain there had been yet no perceptible decay, as one by one the crickets had dropped off or departed. Yet Dolly, wondering wherefore, would sometimes sigh, and even fearfully, to think that their merry chorus had dwindled to a solo ; but the single musician was all the more noted and welcomed, while his voice seemed to have gained in volume and in cheery import.

It was now, as we have said, uplifted shrilly, overpowering, to our attentive ears, the mingled storm-sounds of that winter's evening, as we sat, Lucy and I, with our eyes bent upon the entrance of his retreat, to catch, if we might, a glimpse of his long waving horns or of his shining corslet reddened in the blaze. "I think I should like," said Lucy, musingly, " to be a cricket;" and she placed, as she spoke, in mine her little soft hand, which, in spite of the glorious fire, felt, as it mostly did, very cold. "I think I should like, like him, to 
sit all day by the fire, with nothing to do but sing, and never have to go to school."

"You!-you, Lucy!-wish to be a cricket ?" answered I. "You, who love so dearly the fields and the flowers, and the sunshine, and the bright sky, and the beautiful butterflies; you wanting to be shut up the live-long day-suminer, perhaps, as well as winter-with nothing to look at but the red fire, the black chimney, the kettle, and the saucepan; with no sweet song of birds or hum of bees to listen to, only the wind in the chimney, or the clatter of tongs and poker, or the tic-tack of the jack!" "Poor thing! I never thought of summer," exclained Lucy, her envy converted all at once into compassion; "poor cricket! how I pity you !"

"Nay, now, Lucy," returned I, assuming, as I often did with my little cousin, the air of an instructor,- " nay, Lucy, you need not pity him, for, like all the creatures of the good God, he is very happy in his way. He at this moment says or sings so; only listen to his chirping-no, his speaking solng :-

Say not the ericket's life is dull!

My life-of endless changes full.

Dry wood erackling, green wood hissing;

Rampant flames that scold while kissing.

Bubbling saucepan, singing kettle,

Cheery ring of clashing metal ;-

Sounds noteless in dull ears like thine,

Make music, music sweet in mine.

Say not the cricket's life is dull!

My life-of endless changes full. 
In sights to charm my fire-proof eve

What creature half so rich as I?

Spiral tongues of rainbow hue, Flames of yellow, red, and blue, Now dancing in fantastic haze, Now rising mingled in a blaze; Blocks of burning wood or coal, To common sight a formless whole, To mine a fairy region bring,

A world of which myself am king;-

Of hill, and dale, and rock, and wood, With fiery river, lake, and flood.

Say not the cricket's life is dull! My life-of endless changes full.

Another world is no less mine, The sun-lit world thou callest thine;

For when Summer's at his full, When fields are bright and fires are dull,

Then I spread my ample wings,

And blithe as e'er a bird that sings,

Swift and musical as he,

Perch upon a sunny tree,

Or within some southern wall

Find or make my summer hall.

Say not, then, my life is dull,

The cricket's life, of changes full;

To which, with all, the gift of Heaven,

Its own appropriate joys are given."

While I thus, in sing-song, described the pleasures allotted to our fireside friend, he all the while chirping his loudest in second to my almost whispered words, I seemed almost, to myself, to be only playing the part of a running interpreter to his uttered speech; and as for Lucy, to judge by the attentive wondering expression of her thoughtful countenance, as she 
sat with lips apart, her large dark-blue deep-fringed eyes fixed intently on the songster or the songster's hole, she appeared to believe, thoroughly, that the cricket, and nobody else, was the teller of his omn story. This was hardly ended, when there came a sound of foot-scraping at the kitchen back door, which presently opened and gave entrance to a gust of east wind, and to the person (not uncongenial with it) of Caleb Caligraph, returned from seeing that the visitor's horses had been, like their masters, hospitably entertained.

Having rid himself of hat, great-coat, and lantern, Caleb joined our company by deposit of his stiff, ungainly figure in his own arm-chair, in which, by the way, he never seemed to take his ease; not, howerer, till he had duly recognized our presence by two separate inclinations of his queer, incompleteshaped head, inclinations of twofold character,-lialf, bows of respect to his master's daughter and master's nephew, half, nods of patronage to the children he had known from infancy, to whom he had imparted, or was imparting, of the art and mystery of penmanship and figures, and to whom, above all, he had given presents, - the annual present, that is, at Cliristmas, on the exact amniversary we commemorate, of a king and queen of gilt gingerbread. Well did we know that the royal pair were even now reposing in the waistcoat-pocket of the giver, whose always important air, more important than usual, gave undoubted assurance of the fact. But not for this did Lucy accept with alacrity of the awkward invitation which Caleb 
presently gave her, (a practice as invariable on that particular evening as his annual gift,) to sit upon his knee, there to undergo the ceremony of its presentation. In fact, poor Lucy could not bear old Caligraph; - - there was not a child that could. Whether it were from his ugly ink-blot eyes, his liny parchment face, his monotonous creaking voice, his sharp, angular figure, clothed always in a sort of half dominie, half clerical livery, grey and black, large-buttoned, and of a fit as tight as his knobby joints permitted; whether it were from any or from all of these uninviting external attributes, or because Caleb tried to teach her figures, the only thing she could never learn, and never, like Dolly, told her a fairy tale or sang her a song or hymn; but so it was, that in proportion as the little girl loved her kind nurse, she hated,-no, no, she could hate nothing,--but she shrank from her nurse's old fellowservant, though, to do him justice, he meant, in his way, to be kind too.

Happy, therefore, was Lucy when the sound of my uncle's bell summoned Caleb, in his capacity of butler, to the parlour; and happier was she still, as she slid from the uneasy pinnacle of the old man's knee to run into the soft yielding arms of Dolly Dove, who at that moment re-entered from her toilette in all her Christmas glory. Poor, faithful, kindhearted soul! never again didst thou appear as on that night to do us honour; thy round, plump person, rustling, as was its annual wont, in a silken gown of ancient fabric and as 
ancient make, once the property of my uncle's mother; thy round ruddy face throwing out, like the fire, an extra glow congenial with the season-thy small blue eyes an extra glisten - thy flat white curls an extra polish; and all set off by thy best lace-bordered cap-the cap of caps-with crown like a pyramid of snow new fallen, bound by a broad red ribbon, and faced by a gigantic bow-thy fat throat encircled by a band of black velvet, thy ample waist by the string of thy best worked apron. Ah, Dolly Dove! thou wert then at thy culninating point of honest happiness and pride! Never again did we thus behold thee, and for that reason have we now retraced thy portrait as imaged in daguerreotype by the morning sumshine of our youth and the setting beams of thy (till then) most cheerful age.

When our party of four was finally arranged,-Mr. Caleb in his arm-chair on one side the fire, Mrs. Dore presiding over her tea-board opposite, we, their guests, in intermediate places by the table,--my little cousin began to relate how that we had scen the cricket, and to repeat, with a little of my prompting, a few couplets of his speaking song. Dolly listened with grave attention, and when the rhymes were ended,-- "I can't say," said she, "that I ever heard a cricket sing as plain as that; but there's no knowing, they're such wonderful creturs in their doings, lapping the milk as nateral as old Tom there, and eating bread and butter as hearty as a Christian. Then to see how they run amongst the red-hot ashes with 
never a foot burnt or a whisker singed, just like, if I may say so, the three holy children in the book of Dan'el ; and what's most unaccountable of all, and what makes me think above all that they must be of the natur of sperits or fairies, they comes and goes all of a sudden, nobody can tell when or how." "Why, Dolly," said I, "they can burrow, you know, and creep through crannies; besides, they have large wings to carry them wherever they please." "Well, dear, if they have, they're not like a rale insect's, a fly's or a bee's, standing out plain and straight to be seen by everybody; besides, I've never seen one a-flying of the hundreds as used to come to this fire-place. But let 'em come and go however they may, one thing is cer. tain, good luck comes with 'em, and, whenever they go, turns tail at the same time. Crickets is certainly wonderful creturs, -if not sperits, more like 'em than anythink else that comes about us." "You forget, Dolly," said I, "your favourite black beadles." “No, dear," returned our Dove, "I don't forget 'em,-never have, never shall, since I lived in my first place, where I was like to die, up at London, at Master Mortiplume's, the undertaker's. To see how they swarmed in the kitchen after dark, like his own people at a grand funeral ; but, thank goodness, there's nothink like 'em here, them beadles as they call 'em: but its my belief they're somethink worse than they seems, as the crickets is somethink better."

Here Mrs. Dove was interrupted by a short dry cough from Caleb, but it did not silence her, for "Where," she proceeded, 
"where, I should like to know, is all the house fairies gone to, 'cepting into the bodies of they little creturs? and if the crickets is good sperits, what ever is so like the bad uns as they beadles?-they that hates living people and everythink lightsome, taking care, as if they'd a troubled conscience, to keep out of sight of sun and fire, and everythink bright and cheery, coming out from somewheres, all in the dead of night. like ghosts and goblins, only greedier, gnawing and spiling: everythink they lay their ugly claws on; but, thank goodness, as 1 say, I never see one here, not one like them at Mortiplume's, and hope I never shall !"

Lucy looked round fearfully, and got closer to her nurse's elbow, as the latter brought thus to an emplatic termination her monographs on the families Achetide and Blattide. They were followed, also, by another sound, compound groan, cough, and whistle, from the liny lips of Mr. Caligraph, succeeded, this time, by the sententious apothegm- "Superstition is the daughter of Ignorance," uttered with a look of unmistakeable application to Mrs. Dove, who, dove as she was, seemed slightly ruffled. "I know," said she, "though I'm my father's own daughter, that I'm not so wise as some folks, but I think, Mr. Caligrub, you might be a little more perlite, now, at Christmas time, and in the company of little Miss here, and Mastcr." "Why," returned the butler, alias librarian, alias writing-master-" respecting the young lady and young gentleman, I must take leave to observe that 'youth is apt at 
learning,' and that-ahem !- ' to instil false notions is not good.' ' Fairies are fabulous,' and so, in my opinion, are spirits too,-I always set my face against them, always did; and as to crickets and kitchen beetles, those mean hinsects, of, I should say, the genius Hachetidy and Blatty, to talk of their being fairies or spirits, why" -

Here the fire-side chirper, who for the last half-hour had been perfectly mute, burst forth with such shrilly loudness as nearly to overpower the low husky voice of the prosaic setter. down of Dolly's superstitions. Caleb's material and moral machines were neither of them easily worked into accelerated motion, but whether by extermination at once to silence the familiar of our hearth, or by his death to convince Mrs. Dove that he was a cricket and nothing more, he gave a violent kick with his great splay foot against the side of the fire-place, over the very spot whence the insect's voice proceeded. Down fell some flakes of plaster, and away, over the heated hearth, towards its opposite side, scampered the assailed cricket. But his movements were not half fleet enough for the ruthless Caleb, who, deaf to our interceding exclamations, and regardless even of falling embers, seized the hapless runaway by one of his long leaping legs just as he had made good lis retreat into a snug cranny between the bricks.

Thus hard pressed and hard pulled, the cricket abandoned his leg, and leaving it, a trophy, in the hand of his persecutor, disappeared within his hard-won place of refuge. But Caleb's 
dubious victory was not without its price; a red coal fell upon his fingers, and, his immoveable visage drawn for once into a grimace by pain, spite, and disappointment, he threw the dismembered limb into the fire. Lucy burst into tears; I, to see her, doubled my fist, and actually dealt our writing-master a sound blow; and as to Dolly, no words, no pencil can depict the change that came over her. She neither shed a tear nor would she have struck a blow,-hardly felt, perhaps, either sorrow or anger, all else swallowed up in a sudden shuddering presentiment, fearfully anticipative of some coming calamity, connected mysteriously with the violence just done to the cricket, the last cricket of her hearth, the last good genius of our home.

She looked at Caleb, and Caleb's ink-blot eyes were actually downeast at the look. It seemed to prick, for the moment, eren through the hard-sized pasteboard of prosaic rigidityformal self-importance - want of sympathy-want of power to sympathize, which enveloped that shrivelled bit of internal anatomy we must call his heart. He and Dolly had lived together for near upon half a century, and, antipodes as they were, habit had connected them by a sort of at least imaginary axis. They had likewise a central point of attraction (the sun of the system round which they had so long revolved) in their quiet, kind old master, to whom, and to all that belonged to him, they were each, according to their natures, diversely attached;-Dolly warmly, devotedly; Caleb habitually, mechanically. 
Well, Mr. Caligraph was certainly sorry or compunctious for having maimed, perhaps killed, the cricket, and so shared in a measure the discomfiture he had brought upon us all. He gave us no more of his copy-book moralities, and as soon as tea (that tea all ruined by the cold water of the evening's catastrophe) had come to a premature and untimely end, he muttered something about something else he had to see to, and left the kitchen.

We were glad when he was gone; the monster! the ogre! that had killed, if not the cricket fairy, because perhaps it had a charmed life, but certainly all the pleasure of our evening. That was dead past recovery. In vain did our gentle Dove strive bravely to flutter off her burden of forebodement. When she tried to relate to Lucy, for the hundredth time, the story of Little Red Ridinghood, the wolf seemed to her glaring in, with hungry eyes, at her own kitchen casement. When she took out from the drawer of their year's repose her yellow pack of cards, and attempted a game at "beat my neighbour," strange thoughts would come across her mind that we, some day, might be driven "out of doors ;" and even when we all tried against each other to build card-houses, not one would stand a single moment, any more, thought Dolly, than a house of brick or stone when good luck, or the crickets, have been driven from its hearth. Even the supper-cake (for it was not cut at tea) proved a failure, heavy as the evening which saw 'us in bed (Lucy and I) an hour at least before the usual one 
on the same anniversary; and while my little cousin cried herself to sleep, either for the cricket's disaster, or the sight of Dolly's distressful face, which, for all her kindly artifice, she could not veil from the penetrating eye of childhood, I listened long to the moaning of the snow-wind, and dreamt, when I closed my eyes, of Dolly's black 'beadles,' her first master, the London undertaker, and a tolling bell.

After Lucy was in bed, Mrs. Dove redescended to the kitchen, and joined Caleb, to await the return home of the other servants, and the always tardy break-up of my uncle's social sederunt. She, poor soul! had lost her appetite, but she laid on supper for the old man, and even took down his pipe and placed it by his side. Softened, perhaps, for once, by these unmerited attentions, the offending butler, now that we were no longer present to witness his lumiliation, actually made up his mind to express something like contrition for the deed he had committed. After sundry uneasy contortions of limb and feature, the hard lines of his face assumed something of a deprecating turn. He drew his chair towards that of his vis-à-vis, and then, in a voice not unlike the scraze of its legs upon the brick floor, gare utterance, as if with infinite effort, to the undeniable assertion that "Forgiveness is gracious."

Dolly, with a sorrowful but most forgiving smile, shook her head; "Ah, Caleb!" said she, "you were in a pet, and 1 suppose couldn't help it; but sure as we are sitting here, something amiss will come over this old house before another 
Christmas. Well, you may look as if you didn't believe it; but we slall, see."

At the parsonage we were all in our different ways ardicted to entomology; following therein the example of its master. He himself had ever, it is true, displayed more of the butterHy than the bee in his acquisition of knowledge. To one kind never devotedly constant, he had visited a number of the flowers of learning, but it was only for desultory sippings of their sweets, which were seldom, by any transmutive process of his mind, converted, bee-like, into honey for store, or substance of use more permanent; or if anything like honey was ever thence elaborated, it was dropped, more than directly imparted, for the benefit of others who could imbibe it only after the manner of ants when they follow for their sweets the trail of aphides. Something after this fashion we had all, as we have said, including the two chicf domestics, picked up a something about insects, learnt, at all events, to look upon them as things of some importance, with which, moreover, we had each, in our way, some personal concern. My uncle possessed a cabinet of entomological specimens, with a case full of entomological books, finely illustrated,-also, in the season, an insect menagerie, of which the collection and the feeding was chiefly mine. The care of the cabinet and the books, as coming within the province of librarian, fell to the slare of Caleb, who having, in their camphoring and dusting, madc himself acquainted, by halves, with a few scientific mames of 
orders, families, and species, believed himself, from the acquisition of these scanty chips, to have become a deacon in entomologic craft.

To the little Lucy the painting of the science, or the painting of its objects as displayed in the beantiful moths and butterflies and beetles of her father's cabinet, or the splendid plates of his illustrated works, was, of course, its most inviting feature, excepting, perhaps, its poetry, eagerly drunk in by her childish spirit, as it responded in innocent delight to the murmur of insect voices, followed gaily their painted or their iridescent wings from flower to flower, or rose suspended in joyous ecstasy with the May-fly of the morning. Then, as to Dolly Dove, nurse, housekeeper, nay cook besides, as she sometimes was, it was in a modified form of the same spirit, picture-loving and poetic, that she had followed with a flight much bolder than his own, the leading of the family's head in the flowery field of entomology. Scarcely less delightedly than Lucy, had she often admired, through her spectacles, the gems of my uncle's cabinet, or, walking out with us in the pleasant meadows, noticed the winged revellers at their summer sports. But it was chiefly as objects of her simple superstition that certain insects held in the estimation of Dolly an adventitions rank, raised, instead of lowered, since the remote commencement of her service in the minister's family. She was accustomed to regard her master under a twofold aspect of devoted affection and profound respect. As the man whose childhood 
she had helped to rear and tend, she loved him better than anything on earth besides, excepting perhaps his own child Lucy; and as the reverend divine and the scholar-to her, as it seemed, of most stupendous learning-she looked up to him as a being almost of superior order. Things which he thought worthy of so much notice could not be other than important in her sight; and his attention at times to insects-his keeping them alive and dead-his bulky books and fine pictures in which they figured-above all, his sometimes, as Caleb in confidence had told her, writing about them, and sending what he wrote to men, learned like himself, in London, these facts not only magnified in her esteem the most undreaded of the insect crew, but enlarged, in proportion, all the fearful fancies with which, from early days, her imagination, the apt disciple of ignorance, had learnt to invest a certain few amongst its darker members. We have seen, already, the foundation of her special abhorrence of the common cockroach, known better as the black beetle of the kitchen, when, a young girl fresh from the country, she found a living burial in the family of a London undertaker. Who can wonder that they became from that time objects not less redoubted than the death-watch or the ticking spider, and opposed to her favourite crickets as dark malignant goblins to bright fairies or good spirits, as defilers and destroyers of all household amenities to their encouragers and preservers, as forerunners and foretellers of evil, to harbingers and promoters of good? 
On the morrow after the disaster of the cricket, my cousin and I were again the guests of Mrs. Dove, but then in her own, the house-keeper's room, for my uncle spent the day in bed, a custom of no rare occurrence on that which followed his annual academic commemoration. The next morning, however, being that of Christmas-day, we breakfasted, as usual, in the parlour, and received, each of us, a hearty kiss, and a blessing as hearty, appropriate to the season. In the same orerflowing spirit he failed not to garnish both our plates with nicely apportioned slices of the spiced beef which always, at the festive scason, reigued paramount over the ham and tongue of ordinary breakfasts. After having himself done ample justice to the ruddy round, he had just equalized its surface by a last shaving, Lucy, lately promoted to the office of tea-maker, was pouring out his third cup, when Caleb entered, and laid two letter's on the table by his master. The stable-lad had just brought them from the neighbouring fishing-town, whither he and the fat pony were in the habit of repairing thrice a week to fetch prawns and despatehes. Of the two just arrived, one was a Christmas annual from my father, the vicar's brother, a nierchant in London, the other a stiff, business-looking letter with a large seal, which my uncle, after he had read aloud the contents of the first, proceeded to open. Though fifty years have passed since that morning, I seem to have now before me the countenance of its reader under the talismanic change wrought by that piece of paper. He secmed to gulp down a 
rising exclamation, but it was more than he could do to swallow with it the remainder of his breakfast. Presently he put the letter in his pocket, rose, and left the room, bidding Lucy prepare for church, but in a tone as altered as his looks.

We walked with him, as usual, to our place of worship, crossing a field behind the parsonage, which cut off an angle of the road leading seawards and to church. Fresh snow had fallen in the night, and the swept foot-path was bordered by heaped-up ridges; but not as usual did my uncle threaten to roll Lucy in the flaky feather-beds, nor, when we reached the high stile between the field and road, did he, as usual, jump her over it; and even when the few villagers, bound churchwards like ourselves, doffed their hats and dropped their curtseys, they failed to receive, as always, the returning nod or smile, or word of recognition, from their good-humoured, easy pastor.

The effects of the vicar's letter of the morning were no less discernible in his little antique reading-desk of carved oak. To the consternation of Mr. Caligraph, who sat under it, next the clerk, and the sore bewilderment of those of the congregation who possessed prayer-books and could read them, the three psalms appointed for the morning's service were omitted in favour of those for the 23rd of December, the date, probably, of that mischief-working spell. In the pulpit it was still worse. Each accustomed ear pricked up, as usual, for the sermon, and, expectant of a text appropriate to the day of 
solemn jubilee, was startled by the truthful declaration that "Riches certainly make for themselves wings," a proverbial morality introductive, as might have been anticipated, of a lecture on the vanity of earthly possessions, - of a sermon, in short, which the preacher, lost in the absorption of that morning's news, had taken, perhaps inadvertently, perhaps intentionaily, in place of that he had before designed to use. Perhaps, in the continued prepossession of his mind, he was insensible himself to the unseasonableness of his subject, a fact to which the two or three Dires of the parish were especially alive, nor was it even lost entirely on the less sensitive poor, or on two or three strangers from the fishing-town, a nascent bathing-place, adjacent. These latter, however, had come chiefly to take a look at the interior of our village church, which was, in truth, worth looking at, for its remote antiquity, with its low Saxon arches, contrasted by a Gothic few of later erection, and its curious pulpit of carved stone, attached to a side wall of which it seemed a part. Another peculiarity distinguished the sacred seat which my uncle used once a week to occupy. On those occasions he preached literally and immediately from under the ivy, of which a very large branch, having forced itself an entrance through the massive wall of the church, ran along the interior till it reached the pulpit, ligh over which it formed a leafy canopy of deep glittering grecu.* During the service of that Christmas morning (by me

* This is actually the case in the church of Climping, Sussex. 
never to be forgot) there occurred an incident, in itself trifling enough, yet of a kind well adapted to impress itself on the mind of childhood, as well as to divert attention of the congregation in general from the blunders of my poor uncle either in choice or delivery of his discourse. A robin had found its way into the church, and, perched now on one, now on another of the sprigs of holly with which the perss were decorated, lifted, at intervals, his sweet notes above the deep and somewhat monotonous voice, which, except his own, was alone audible.

This was not the first time that Robin, or a fellow in his livery, had excited not alone our notice (Lucy's and mine), but also our pitiful sympathy, to think that he, like Goody TwoShoes, might be shut up in the church, and, less fortunate than that celebrated little bell-ringer, be left to starve, and deposit his remains, by leaves unshrouded, on the cold bare stones. Some such sorrowful apprehension was crossing my own mind, and, I was certain, my little cousin's, when Bob, taking a higher flight, perched upon the ivy which canopied the pulpit. Then, shaken by Robin's wings, startled by his chirp, aroused by the voice of the preacher, or warmed into activity by the ascending breaths of the congregation (a stove in our parish church was a thing unknown), out flew from the evergreen cluster a peacock butterfly, and away, open-mouthed, Robin after it, here and there, backwards and forwards, betwixt the sunny south-eastern window and the dark, narrow, frosted loop-holes opposite; the insect peacock, by alternately raising 
and lowering its flight, contriving always to elude the gaping jaws of its more powerful pursuer. Ah, Robin! thy rapacious pursuit of the imnocent was wofully out of place in that hallowed fane; but where, alas! is the sacred edifice not defiled on each returning sabbath by pursuits more desecrating still, pursuits of careering headstrong will after wealth, and pleasure, and perchance revenge, carried on by some, by many of the lip-serving and worldly worshippers met together in what they denominate their house of prayer? The novel chase (novel, at least, in the scene of its "coming off") lasted longer than the sermon, so that its results we never knew, except that it served, as we have said, to divert the attention of some, perhaps older than ourselves, from the matter and manner of the pastor's unseasonable selection. My poor uncle! on an ordinary day, he too would lave been diverted, perhaps to an indecorous extent, by that bird and insect episode.

It was some time before the nature of that Christmas intelligence by which the vicar was so sensibly affected became apparent. For awhile there was no change within his household, save in his own dull depressed demeanour, with a sharde of sympathetic gloom discernible in the face of Mrs. Dove. Then, as from a tree sliaken by autumn blasts, every redundancy was seen to fall from the comfortable establishment of the parsonage cottage. House- and kitchen-maids, stable-lad, and gardener, were one by one dismissed; the cows were driven to a fair ; the pony became the property of a neighbour 
farmer. The supplies of old pensioners dwindled till they died. The kitchen range became of course proportionately contracted, the jack was rarely heard, and as for the cricket, that was never heard or seen at all-never since that fatal evening; - -he was departed-dead, or, if of mould immortal, mortally offended.

In a language of signs too significant to be mistaken was thus revealed the purport of that chilly greeting which had met my uncle upon Christmas morning; - the announcement, for it was none other, of his banker's total failure, involving the loss of his whole fortune, except the slender income derived from his very small, poor, and lowly-tithed parish. On this he might have lived still in tolerable comfort, but he had always been lavishly generous-lavish also in the gratification of his personal tastes; amongst others, that for costly and expensive books, those especially on the science of his fancy, and herein of his pride. In his shallowed resources he now found himself deep in debt; and through deeps and shallows he knew not how to steer.

Even the cuttings off above described were made with tardy hand, because my poor uncle, in his feebleness of moral purpose, was quite unequal to imitation of the bee or caterpillar, which with instinctive decision are always found to accommodate their operations, forthwith, to straightened circumstances. Every one who has studied bees and reared caterpillars will know we do them only justice. 
It may seem strange, but the boding impression made on Mrs. Dove by the wrong done to the favourite of her hearth did not appear so greatly deepened as might have been expected by the blow fallen already on her master's fortune. She was doubtless perfectly convinced that it had happened in accordance with her prophetic augury; but perhaps she had expected worse, and was relieved, therefore, at supposing the doom accomplished, and that ill luck or the offended cricket had done its worst.

Then there was another cause why Dolly's spirits bore up so bravely. She was more busy than ever. Prodigious were her efforts to supply to her impoverished master the deficiencies which, but for them, he might have felt in his personal comforts. His dinners were dressed with double care-more profusely garnished, more punctually served. Not a stew-pan did she suffer to grow dull in absence of the kitchen-maid, nor a parlour to mourn in dust and cobrebs for the absence of the housemaid. She supplied the place of all; yet every evening would see her in her cap and apron of unsullied whiteness, the same respectable concierge as in better days, ready by her trim exterior and cheerful aspect to baflle the speculations of all curions visitors, whether to kitchen or parlour, who might come to pry into their minister's altered fortunes. Ah Dolly! (Dove of our childhood's hearth and home!) thou wert a domestic biped of a genus now well-nigh extinct-gone out with the dodo;--and with something, therefore, of even a naturalist's 
pride have we dwelt, perhaps too diffusely, on thy rare endowments.

By the time that winter had melted into spring, a change, apparent even to my youthful observation, appeared in the person of my uncle, correspondent with the fallings off in his restricted household - and in habits also he was no less altered. Indolence, like an ichneumon parasite plunging her fatal weapon into her devoted prey, had beset him even in early life :-it had grown on affluence, and its victim was only lulled into almost apathy by that adverse stroke, which might have awakened some men from the destroyer's grasp.

Although an indolent, my uncle had never been an idle man; he was generally busy about something-busy after the fashion of a caterpillar that should employ its whole maturity in spinning nothing but a mass of mingled threads, loose and irregular, intended for the support of a cocoon which, for want strength, it should never finish-perhaps hardly begin. Yes, my uncle used to be always busy-busy in his garden, that dear old-fashioned garden, with its long middle walk, broad and straight, edged with thrift, flanked by flower-borders-such flower-borders!-their delicacy screened from vegetable vulgarities by a fence of espalier fruit-trees, famed for their produce throughout the village. There, attended usually by by me and Lucy, would he consume many a summer hour, admiring or attending on his cherished plants; watching, perhaps, the labours of a carpenter wasp or bec, or the pro- 
ceedings of a colony of ants, anointing, perhaps, the trunks of his trees with insect bird-lime--sweet syrup to attract and entrap unwary moths,_-or in the warm twilights, sitting, net in hand, to arrest them on the wing. Or perhaps he was as busy in the library, now giving us a lesson, Lucy in reading, myself in Greek or Latin, by way of preparing us, the one for a boarding-school, the other for college; -now skimming the surface of a classic tome,-now gliding over the depths of a father of the church, - now turning over with fondness, half of the naturalist, half of the bibliomanist, the finely. illustrated pages of Merian or of Stoll, those of 'Curtis's Entomology' or the 'Flora Londinensis,'-now writing (perhaps by the hand of Mr. Caligraph) sometimes a sermon, sometimes a few desultory observations on a plant or insect, intended for the Linnæan Transactions, wherein, however (for want of completion), they rarely enough obtained a place.

A man thus occupied could hardly be said to have had a hobby, or, if any or many my uncle had, they were all like rocking-horses, just serving to amuse and keep him in motion, not to carry him to any end; but if the pursuit which had most diverted him was entomology, the object in which he had always taken most pride was his library, on the furnishing of which he had expended, as we have noticed, large sums. The library itself was something of a classic place. Like the rest of the parsonage, it was of ancient build, heary-beamed, low, 
and long, had a carved mantel-piece and a window of painted glass,

"All diamonded with panes of quaint device,"

and it was said, moreover, to be haunted, not alone by the Muses, but by the restless spirit of a poet, who, in the days of his premature decline, had sat there, hour after hour, "spinning" from the threads of thought a "cell" or a shroud for enwrapment of his own "decaying form," till Death, in that very chamber, struck and turned that form into a shadow. My uncle, however, was no man of a mind to fear shadows, and he had (to Mrs. Dove's wonderment) been accustomed at all hours to sit there amused by his desultory studies, in a tapestried arm-chair, said to be the very seat the poet died in. After his misfortune he sat there more than ever; -lost himself, and losing time, in apathetic musing. In the gloom that had come over him, even his favourite insects ceased to interest him. He cared not for the chrysalidan treasures which, while winter lasted, I worked indefatigably with my digger to exhume. He looked with equal indifference on the first "twenty-plume" which was seen in February on the window, and the first brimstone butterfly that made its appearance in the garden. In March, when the first hunting spiders were visible on the sunny walls, and the first satin mites showed their scarlet doublets on the ground, they were seen not at all, or with the same regardless eye. And even when. Lucy and I got him out into the woods, and the first orange- 
tip flew across our path, all bordered with violets and woodanemones and blue-bells, and, above all, the little celandine, he noted not even the first adrent of the working bees as they came from their waxen cells to

\section{"Settle on her brilliant features."}

Though my poor uncle's affairs wore an irretrievable aspect, he had been urgently advised to pay a business visit to the metropolis by friends there resident. Amongst them was my father (his younger brother), who had sunk in mercantile adventure a younger brother's fortune, and was now, with the burden of a large motherless family, only toiling to acquire another. To his abode in the City my uncle had for above three months been promising to repair ; but in a procrastinating spirit, halfnervous, half-supine, he had from day to day deferred his journey till the arrival of the second week in May, when he actually made up his mind to leave his home for the first time for many years.

The morning came on which he was to take the coach from the neighbouring post-town. Its distance of three miles was beyond that of his usual walking, and he was glad, therefore, to accept for the occasion a loan of the pony once his own. Caleb was despatched beforehand to bring it back, and carry his master's portmanteau, with a basket of provision for the journey, provided by Mistress Dove. About eight o'clock the traveller himself started. Dolly stood on the steps, looking 
after him with wistful gaze; Lucy and I (for a part of the way) bearing him company,--she seated on the saddle before lim, I walking by the side. The labourers returning from their work to breakfast looked inquisitive as they tonched their hats, wondering at the object of their pastor's early sortie.

Few were the words, but they were very kind, which my uncle said to us, and fond were the looks-fond and very sad -with which he regarded us as we proceeded slowly along the beautiful winding road, which, after passing the church, ran nearly parallel with the coast to the little sea-side town from whence the stage started. Fond, as I have said, more earnestly fond than usual, were all his looks and words; but of all, none were by me so well remembered as his parting injunction"Take care, Frank, of your little cousin." This was given at the foot of a hill between us and the town, up which he had forbidden our ascent, and just as I was helping Lucy from the saddle after he had given her his parting kiss. Then he kissed me too. "God bless you, my boy! God bless you, my dear children!" and the pony, from habit, broke into a canter, and was presently half-way up the hill. We stood in silence, watching his ascent, till, the summit gained, my uncle for a moment reined up, turned round, waved his hand, and disappeared behind the eminence.

I felt at that moment an unaccountable chill strike to my young heart; but I was to "take care of my little cousin ;" and, seeing the tears streaming down her cheeks, I began the 
fulfilment of my charge, by trying to play the man, and do my best to console and to divert her. $\mathrm{Ah}$ ! it is easy in the days of youth and childhood to impart as well as to receive of comfort; and, on the occasion I recall, many were my surrounding helps from hour and day and season for the consolation of my weeping companion. It was one of those May mornings, bright and blessed, when

"Everything doth pleasure find In all that comforts all their kind;"

when the early carol of the lark came mingled with a thousand matin lays as lovely, if more lowly; when the wings of the ephemeræ, then with their summer day of life before them, were glittering in the morning beam; when the dewdrops shed for the sun's departure were drying up before his kisses on return; so the tears of Lucy soon dried up too, and she could take delight as usual in the sight of her dear blue butterflies-the "azure blues"-contrasted here and there by the broader pinions of a "clouded yellow ;" and at last she could even join me in the chase of a "Glanville fritillary," a glorious insect, rare even on the Kentish coast, and of which I therefore attempted the capture as a prize for my uncle's cabinet. Not, however, with my usual ardour could I follow the pursuit-that had received a damper which not all the influences of the morning could entirely dispel; and then, on such a morning as it was, to deprive a single thing of liberty 
or life-that I felt, if I did not exactly think it, to be a deed unmeet, unsuited. So we soon gave up the "fritillary," leaving him to go where fancy or his silver-spotted wings might bear him, and sitting down upon a bank, all blue and red with speedwell and herb-Robert, we watched with pleasure more unalloyed and quiet the movements of a humming-bird hawk-admiring how, in his morning flight, he kept darting from flower to flower, or hung suspended upon quivering wing as he pilfered his breakfast from their nectared stores.

Numerous besides these was the insect company which enlivened that morning walk; but of only one among them did we make a captive, and that was a cricket-a house-cricketone, withal, deficient of a leaping leg-perhaps the peculiar chirper, the familiar spirit, of Dolly's hearth, which we found basking on a sunny pale. When my little cousin proposed first to take it home, "Lucy," said I, "remember this is summer, and in summer-time the cricket, like ourselves, loves the sunshine better than a kitchen fire."

"Yes, but then Dolly would so like to have him—and yet, poor thing!"-Lucy was, in short, divided betwixt her love for one and her love for all God's creatures; but the former conquered, and the cricket, whether our old acquaintance or a new, became our involuntary companion. Mrs. Dove did not refuse reception to the wanderer or the stranger; but as she rose from stooping to place it in the snug little cranny once occupied by himself or fellow, she shook her head. 
"Ah!" she said, "it's none, I doubt, of ours; or if it is, he's been affronted, and will never stay!"

That evening, Lucy (an unusual thing for her) complained of being tired. I was to "take care of my little cousin," on which account, perhaps, I noticed more than usual both her words and looks; and then, for the first time, perceived in her face an appearance which, young and thoughtless as I was, I did not like. Her cheek looked pale and wax-like, and a bluish circle surrounded her large soft eyes. By the next morning, however, her colour had returned, her step was light as ever, and my alarm, evanescent as the warning tokens which had called it forth, vanished with them. They only, however, slumbered, to be henceforth from time to time re-awakened, in form vague indeed and shadowy, but darkly prognostic of some impending harm beyond my power to avert from the dear little cousin I had been told to take care of.

Week after week passed over, and brought from my uncle only an occasional short letter, of which those received latterly made no mention of return. Neantime, the purse which he had consigned to Dolly on departure waxed low and lower, while, in like proportion, the face of the faithful sterrardess grew more and more anxious, till she was an entirely altered person, in all but devoted affection, testified, if possible, more than ever towards us, her children.

As for Caleb Caligraph, he plied his daily avocations, now more manifold than ever, with his usual clock-like precision, 
even his jaws, to the evident discomfiture of poor Mrs. Dove, abating nothing of their usual mechanic labour on the reduced material supplied by her impoverished larder. Yet something of a change (the result indirect of that in his master's fortune) had been wrought even on the unimpressible temperament of the caligraphic butler. My uncle's Sunday duty was performed in his absence by a divine of a stamp altogether different to himself; - a loud, alarming thunderer-one who shook the dust from the old moth-eaten pulpit-cushion, and from the ivy which hung over it-a rough tool with a double edge of zeal and sincerity, and powerful to cut into the heart through hard horny rinds of ignorance and apathy. Even Caleb, the dull, prosaic, matter-of-fact, circumscribed old Caleb, with whom, in its strictest sense, to see, and nothing else, was to believe, had had, through the instrumentality of this new teacher, the blind eyes of his inner man so far opened as to have caught a glimpse of certain somethings besides formal penmanship, neat beds of onions and carrots, and files of books in goodly array, under his own drill and discipline. For sabbath mornings, fifty times fifty-two, he had sat under his poor master, and repeated with the clerk, and in as loud a key, the creed and the responses, and even in sermon time never closed his great fixed eyes, which seemed like an insect's without eyelids; yet his mind had acquired no more power of grasping aught invisible, of conceiving, however vaguely, of other worlds, of spirits therein, or of spirits that may be "walking the earth 
unseen," than of believing with Dolly that some such existences as the latter were for ever "about us," in the forms of cricket and of cockroach.

Since a few particles of new leaven had been infused (as we have seen) into the old man's never before fermented mind, the automaton, if he could not be said to have acquired as yet the faculty of thinking, would sometimes when his body was at rest have his mind in a sort of bustle, as seeking about for a something it could hardly find. So as the autumn days grew shorter and shorter, and we all four of an evening drew round the kitchen fire, while Dolly was pondering sadly on her master's absence, and about us, and about the cricket, and we (Lucy and I) were thinking, each in our own way, upon the very same subjects, Caleb would, in the blinking fire-light, and in the darkness visible of his barely loop-holed mind, be groping for, and catching hold occasionally of one of the salient points in the new preacher's wonder-working discourses, the battering-rams which had forced an entrance through his mental walls.

One night, late in September, when we were thus assembled -Lucy on a low stool, one hand on Dolly's knee, the other on the head of the large white cat-her eyes, as those of us all, bent upon the fire, she suddenly whispered, "Look there! there's the cricket!" and she pointed as she spoke towards the hole into which our old favourite had run for refuge on being routed by Caleb from his original retreat. "Look there!" 
she repeated; "I see his horns"-and sure enough, by the flicker of the dull fire-light there appeared protruding from the cranny a long pair of waving antennæ. Dolly, eager to be assured that it was the cricket's self, caught a candle from the mantel-shelf, lighted, and held it under the grate opposite the cavity. Its occupant was not dislodged, because probably it was afraid to advance, and had no retreating passage in its rear ; so motionless it sat, staring at the light or its examiner, who screamed with at least equal terror on discovery of what it was. It was no cricket after all, but a dark brother of the same order-one of those broad, flat-bodied, night-loving, alldevouring, all-polluting, ill-scented creatures, the objects, as we have seen, of Mrs. Dove's especial hate and horror.

"It's only a cockroach," said I. " Only! dear," returned Dolly. "You may call it a cockroast; but I knows it well; 'tis a black beadle-one of the very same I saw when I was a girl at Mortiplume's, and never since. There they came by hundreds, and that was bad enough; but here, in this poor old house, it has come by one, and that's worse, for it's sure for certain to be the forerunner of a death, here, in the family, or not far off." " Nonsense, Dolly," said I; “ it's not come to foretell death, but to pick up its own living,-the crumbs, perhaps, at our tea-time; for it's as fond, every bit, of bread and butter as your own cricket; but I'll read to you after tea all about it, and show you its picture, or Lucy shall, in one of Uncle's books. I'll go and fetch it before it's quite 
dark." - "Not to the libery ! - not to-night!" cried Dolly; and she grasped me tightly by the arm. I wanted to go, but did not like opposing the good creature, whose fears of the haunted room were then, we knew, in the ascendant.

While I hesitated, who should come to my relief but Caleb, who, bearing, perhaps, in mind his awkward part once in the drama of the cricket, had in this taken hitherto no part at all. "I'll go," said he. "I can inform you, Mrs. Dove, that Master lrancis is perfectly correct; that hanimal is a cockroach-order Coloptery, genius Blatty-I'll get the volume'sceing is believing" "- and he rose to put his purpose in execution. "But won't it do in the morning?" said Dolly. "You'd better take the candle, at any rate."- "Candle!" returned Mr. Caligraph, in his progress towards the door; " moon's up-full this morning-nine o'clock, A. I., twenty minutes-and, supposing it was dark, I can put my hand on e'er a one of the books in the bookcase. I should think soa man in my capacity-Order is admirable."- "Well, if go you will, go jou must; but I wouldn't to-night," repeated Dolly, entreatingly, as Caleb opened the kitchen door, and shut it resolutely behind him.

Perhaps, however, when it was closed, a restraining something, sprung of Dolly's deprecating words or looks, or of his own fireside musings, made Caleb linger on the threshold, for a minute at least elapsed before we heard his creaking step across the hall, up the stairs, and then along the dark narrow 
passage which led into my uncle's study, the door of which we then heard close after him. "He might have left it open, at any rate," said Mrs. Dove, with a look of fluttering wonderment. Then all were silent, and, in momentary expectation of Mr. Caligraph's return, minutes went on till they made up perhaps a quarter of an hour-but no Caleb re-appeared. What on earth could he be about? I would have gone to see, but an imploring look from Dolly kept me back, till, thump! came the sound as of a heavy fall in the direction of the library. We all three started to our feet, and Dolly was the first to reach the kitchen door; there, however, she hung back, and, holding Lucy back by the hand too, followed me, bearing the candle, up the stairs.

The book-room door was shut, and something within obstructed its opening. Open it we however did, wide enough to gain admittance, and then, on the floor behind, found extencled the prostrate length of Caleb. Dolly's fears took at the sight a new turn; she held the candle with a trembling hand over the features of her old fellow-servant, fixed now in even more than usual rigidity; but when by their scrutiny she had ascertained that nothing serious, in the way at least of bodily disorder, had overtaken him, she drew from that travelling dispensary, her ample pocket, some pungent restorer of the wandering senses, and plied it assiduously till Caleb opened his ink-blot eyes, and, with recollection still at fault, recovered slowly sufficient of corporeal energy to rise from his recum- 
bency and totter, supported by the arm of Mrs. Dove, to his dormitory and his bed. There we must leave him, and, taking a few steps backward, relate his experiences of that memorable evening, as in substance or in shadow they were imparted next morning in the weakness of recent terror to the eager but anticipative ear of Mrs. Dove.

He had, as he declared, just entered the library, when the door, as if taken by a draught-though wind there was none-shut to behind him. The moon was shining brightly through the casement opposite, and threw a long black shadow on the floor from the high antique arm-chair - the poct's chair-placed then with its back towards him, and fronting the library table, which stood not far from the cold empty fireplace. Caleb proceeded towards the bookcase, that division of it a little to the right of the chair, and just above it, which he knew so accurately to be the precise place of the desired volume. He stood under it-his arm was raised towards it; but another arm was stretched forth at the same time, and another hand, pale and shadowy, took down the book before he could lay hold of it. The apparition to which that hand belonged must have risen from the great arm-chair, whose back had screened it on his entrance; and before Caleb had time, if he had dared, to look upon its features, was again reseated, back towards him, book open, at an illustrated page, whereon it was pointing with its thin white finger to the figure of a cockroach. The terrified looker-on saw it clearly for a moment, as in its 
natural proportions on the paper ; then, swimming in a haze of misty moonshine, it seemed endowed with life and motionwas magnified-multiplied into a loathsome swarm-a dark, besetting, horrifying legion, which rose, some on wing, some crawling round him-glared at him with their horny eyes from beneath their overlapping corslets, waved their long antennæ, and thrust their spiny arms into his very face. Caleb had seen enough, and attempted, his few teeth chattering, and his knobby knees knocking, to effect his exit from the library; had almost reached the door, when a cold arresting hand seemed laid upon his shoulder, and he fell, as we had found him, prostrate on the floor.

"Master is dead," said Dolly, after hearing the above relation. "Master is dead; I know it ;"-and her superstitious awe giving way presently to heart-breaking sorrow, she burst into an agony of tears. "Why," remonstrated Mr. Caligraph, "I do not say I saw its face-only its back-in the very coat that now hangs empty in the libery; besides, Mrs. Dove, you know, as I have before observed, 'superstition is - the daughter of - "' but here the words died upon his lips; and the mechanic amanuensis grew from that night more thoughtful than before, and never stayed in the book-room, or volunteered to visit it after dark or dusk.

If news of death were really on their road to us, as our Dove was now thoroughly persuaded, they travelled, like a hearse, slowly. Tidings none at all reached us of my uncle; 
but howsoever it might fare with him, his house seemed more than ever stricken with death-like symptoms of decay. Dolly's remaining energies all sank paralyzed under the last anticipative shock. She relaxed now in those labours of love by which, while her master was present, if she could not kcep poverty from his door, she contrived to hide the spectre from his unaccustomed sight. Now, indeed, did she suffer the dust of desertion, real and metaphoric, to fall heavily on our once cheerful and neat abode. She was like a working bee, able to work no longer under bereavement of the hire's head, and our habitation, of which a well-stored hive was once the likeness, resembled now an autumnal wasp's nest doomed to destruction and decay. Windows grew dim; walls wept, for absence of fires or their master; doors creaked; shutters hung loose ; and even the kitchen, with its contracted range, and dulled perters, and corroded coppers, though now the only room of habitation in the house, partook in a measure of the desolation and disorder which had orertaken its fellow apartments of a higher grade. No cricket was ever seen or heard; but the solitary cockroach which had usurped its place was often visible.

In the garden the ordinary touches of autumn were invested, to me, with more gloomy hues than they had ever worn before. Frosts had been sharp and early, and the dahlias, as they hung black and drooping over the middle walk, seemed to mourn for the admiring master who, in his own pride, had so often propped them up in theirs. One of the October objects of 
our interest and amusement had used to be the numerous beetles abroad then in search of their provided winter homes; but their activities now, as they crept rustling amongst the fallen leaves, seemed suggestive only of a heavy presentiment that our asylum would speedily be less secure than theirs.

But amidst these deepening tokens of decay, within doors and without, one was, to me at least, more perceptible, more heart-saddening than them all. Lucy, my little cousin, of whom I was to take care-she, too, in her early spring-time, was overtaken by autumnal blight. The warning tokens which had first attracted my attention on the evening of my uncle's departure, now went, now came-came at last in form not to be mistaken. The cough - the hectic flush-the sparkling eye - the childish beauty, wearing now an almost unearthly bloom, now a faded pallor, which bespoke too plainly its mortal character,-all these told me, though hardly would I believe their tale, that I should not long have my little cousin to take care of.

One cheerless rainy afternoon in November we were all as usual in the kitchen; Dolly seated by the dull fire, darning stockings, and wiping now and then her large round spectacles, which, from the damp atmosphere or some more immediate cause, seemed from time to time to grow dim; Caleb, opposite, reading a religious tract-one of those which the new preacher had distributed; I and Lucy standing by the window watching the heavy rain-drops and the light brown feathery leaves falling in a mingled shower from a deciduous cypress, which stood on 
the grass-plot opposite. It was one of my poor little cousin's most indifferent days ; - she seemed very dull, and I saw, though I would not appear to heed it, that while we were looking at the cypress the tears were quivering on her long eye-lashes. To divert her, I pointed out on the window-pane a pair of those pretty little hardy insects, known as midges, or Psychodce, now traversing the glass in their singular sidling manner, now flitting lightly from diamond to dianond of the leaded casement. In following their movements my cye fell upon another insect object-a herald moth-a herald of winter, which, as it rested on the window-frame, bore something of the appearance of a triangular painted shield. Of such a shicld " the Herald" had often reminded me; but somehow, as I was looking at it then, I thought also of the hatchments suspended in our church. Just as the comparison had struck me, there came a ring at the garden-gatc-a ring low and half-fearful, as if the bell were pulled by a timid or unwilling hand. Keeper barked loudly; but it seemed to me as if there was more of recognition than of anger in his roice. We just saw the top of a hat-a gentleman's hat-above the close high gate. "It's papa!” cried Lucy_ “ it must be papa!” Dolly's stocking fell from her hand; but she sat still-she couldn't, or she didn't dare to move. I said nothing; but my heart beat violently when, after a short parley at the gate, I saw who it was that entered and approached the house. It was my father, and he had come to bring at length news of my uncle-news 
that he was indeed dead. His visit to London had been fruitless, excepting only of harass and fatigue. His banker's failure was complete, and he had been disappointed also of a small living, but of greater value than his own, which had lately fallen vacant, and of which the patron had given him a promise years ago when he did not want it. He was on his way homewards by the coach, when, as he was dismounting at an inn, where the stage stopped, he fell in a fit of apoplexy at the door. He survived only a few speechless hours; but from papers found about him the people of the inn were enabled to write to his brother, who arrived in time to find him just expired. He had left no will-had, indeed, excepting debts, little to bequeatl. His remains were laid within the shadow of his own chureh, beside those of Lucy's mother; after which my father stayed at the parsonage but a few days, employed, as days after death usually are, in the cold curious business of prying into papers and personal effects of the departed, and in forming such new arrangements as death may make requisite for those left behind.

To us, the four so long dependent on my generous easy uncle, the two old servants, Lucy and myself, what a breaking up did his decease involve! Though savings-banks were not then established, Dolly had happily laid by an annual something out of the wages of her half-century's service amounting to enough to keep her from want for the remainder of her days-a remainder which she was to spend in her accustomed 
village, in a humble cottage not far from her accustomed home, of which the clustered chimneys, inclusive of her own, the chimney of the kitchen, would be at least within her daily sight. Caleb also had his hoardings, bigger ones, we suspect, than those of his open-hearted fellow-servant; but he did not seem disposed, like her, to commence housekeeping on his own account. Time was when it would have been no greater miracle for his late master's library chair-the poet's chairto have walked from its place, than for Mr. Caligraph to have expressed a wish to leave the old house or his accustomed haunts and avocations; but both place and occupation were leaving him, and since the evening of the apparition even the house had not seemed the same to Caleb, or he to the house.

One day that my father happened to speak in his hearing of having lost a confidential clerk, the ci-devant writing-master and butler proposed himself to fill the vacancy, an offer which, on account of his long services and strict integrity, was not refused. For myself, all college prospects and collegiate honours melted into air; I could only acquiesce passively in my father's purpose of deroting me to the drudgery of the desk in a friend's counting-house, where he could almost reckon on my elevation to-a high stool. And last, not least, for Lucy. My father proposed (what could he do less?) to make the pemiless orphan child a nember of his family-his large family-which he could even now barely manage to support. The plan was a tempting one to me. We should not then 
have to part. I should see her at least every morning and every evening when I came home from work. But when I thought of a close house in the heart of the City; of no care for her but that of a coarse miserable drudge of all-work; no companionship but that of my noisy neglected little brothers and sisters, I faltered in my wish; and when I looked at her fragile form, grown of late so tall and thin, and at her transparent, flower-like complexion, " $\mathrm{Ah}$, Lucy !" thought I, "should I be indeed thy friend, should I indeed take care of thee, to have thee transported, if $I$ can hinder, from this sweet pure air-these fields, and woods, and flowers, and from the wings of our tender Dove, thy faithful gentle nurse, whose heart too is breaking at the thought?" And when Lucy herself, on my father's asking her if she would go to London and see the carriages and shops, hung down her head in sorrowful silence, the struggling self within me was subdued, and I entreated and obtained consent that she should be kept at least for a year or two in Dolly's care.

My father returned first to business, leaving me and Caleb to follow after the latter had seen to the completion of some arrangements for the sale (for the benefit of his creditors) of my poor uncle's furniture and effects. His cabinet of insects and a few of the least costly of his books on entomology my father, at my request, contrived to save for me.

During the week or two which Lucy and I passed together before the day of parting I noticed few comparatively of her 
threatening symptoms; and she looked all childish bloom as well as beauty on that December morning, when she and Dolly, standing at the door of their new abode, watched through their tears and through the driving snow the departure for London of myself and Caleb. In a few weeks I was broke in thoroughly to the career of monotonous drudgery which a few years since only ended. I brought to my daily tasks, repugnant as they were both to the desultory habits and the country tastes formed in my recent home, the energy of fifteen, quickened by a sense of what I owed to my struggling parent and his needy family; and times there were, when this, the early morning of my day of clerkship, was cheered (spite of other and more dark anticipations) by rays of hopeful sunshine-more properly by a sumny haze, wherein, amidst other objects dimly discernible, the fairy form of my little cousin was always most distinct. I saw her again on the Easter following the December that we parted, my first holiday from business, when my father allowed me to pay a few days' visit to Dolly's cottage.

Did I return with renovated hope or fears confirmed? perhaps with hope, for I applied myself to work more steadily than ever.

On the same anniversary-the cheerful spring-time of the following year-on a Saturday, when the church was openthe church with the ivied pulpit-two persons were seen loitering under it, and looking up at its still green, evergreen canopy. They were an aged woman of comely figure and mild 
though then overclouded aspect, and a youth of about seventeen, and they repaired presently from the aisle to the chancel, where they stood together, hand-in-hand, before a simple tablet let into the wall. The names of three individuals had been graven successively upon the marble,-that of a mother, who had died young - a father (late vicar of the parish) - and a child, their only child Lucy, who had followed them at the age of fourteen.*

The foregoing episode of our early days, fraught with sadness and closed by a record of the tomb, may appear a theme unfitting for this cheerful season; but to ourself there has long been much of peace and even pleasure in its retrospect. It is true, that for many a year after the above occurrences, the chirp of a cricket - the sight of a cockroach-the survey of our cabinet treasures - even the cheery hum and busy flight of insect multitudes, gave us more of pain than pleasure, for all seemed then as the veritable spirits of our childhood's hearth and home, powerful to bring before us memories steeped in sorrow. But now, ye winged remembrancers! ye are welcome all, and chief, Acheta, good genius of our faithful Dolly, in whom, for love of her as well as thee, we have joyed to acknowledge our prototype and symbol. Not for this, though, should we have

* The anthor read, some few years since, in a collection of French talcs, a story, of which he forgets both name and writer, bearing some incidental resemblance with the above relation. 
recalled here the period of our early life, the narrow verdant tract which we have just revisited, but because there, as at its source, arose our life-long love and liking for our favourite and allied pursuits. Like a fertilizing spring now hidden underground, now re-appearing, our then awakened love for things of nature has often since been buried, lost, to all appearance, beneath the earthy weight of worldly care and forced distasteful occupation; but, like the same refreshing stream, it has burst forth again at every interval of freedom, and now broadly irrigates the level, and else perhaps barren plain which borders on "the better country." Looking back, too, not alone on our spring sunshine, but also on the early frosts which appeared unkindly to cut off our promise, we seem to perceive now that we are enjoying autumn fruits which but for those very frosts might never have been formed-sacrificed, perhaps, to leafing more abundant. Or, to illustrate what we mean by a comparison more accordant with our prevailing subject-the butterfly, whose wings on their first expansion have been rudely handled, battered by a hailstorm, or even somewhat stinted by compression of its chrysalidan cover, may show but shabby painting or lack-lustre plumage beside its fellows, may be restricted even to less aspiring flights; but little need it envy its more gay companions, if yet able to flit amongst the lowlier flowers, sip their honey, and enjoy the sunshine and the balmy air, while its sobered colouring serves to protect it from the capturing nets and preying bills 
to which they in their conspicuous clothing are the more exposed. Thus has it been with our maturity. By the clouding of our early prospects our youthful buoyancy was depressed, our youthful brightness shorn of its gayest hues; yet to those influences which appeared so adverse, owed we not escape from many of life's early perils? and now, owe we not the enjoyment of many a calm pleasure, vivified by the very privations which might have seemed to kill them? If none like the Spitalfields weaver knows the delight of insect-collecting, none like the city clerk can tell the delight of insect observation caught by snatches upon summer holidays. Such, for many a year, was ours; and now that our working-day of life is over, right pleasant have we found it to take our evening flight away for ever from its weary scenes, and to indulge without restraint in the manifold pleasures of our loved pursuit. Joyous to the bee and butterfly the exercise of their wings and senses amidst the sweets which fill the atmosphere they always live in; but yet more joyous to our prototype, the Cricket, must be a flight like his, when he exchanges for summer air and sunshine the contracted pleasures of house and hearth; and of this description is our enjoyment now. And then-the correspondent boon - boon above a cricket's need or cricket's ken-our escape also from a moral atmosphere, hot, glaring, and heart-oppressive, sickly with the incense offered to Mammon by his servile worshippers, to an air, not, alas! of heavenly purity, but in which the 
lungs of the spirit may breathe comparatively free. Oh! this is a privilege which calls loudly for our evening hymn of praise, and to bear our part in concert with that graduated band descending from angel even unto insect choirs. And ill should we read that "second Bible," the Book of Nature, with all its actual displays and typical revealments, if we read not this - that He who in every episode of insect life is seen to conduct to good the humbler creatures of His care, cannot by us be doing less, in all the dispensations, be they sorrowful or joyous, which form the episodes of our human and, while here, most insect-like existence.

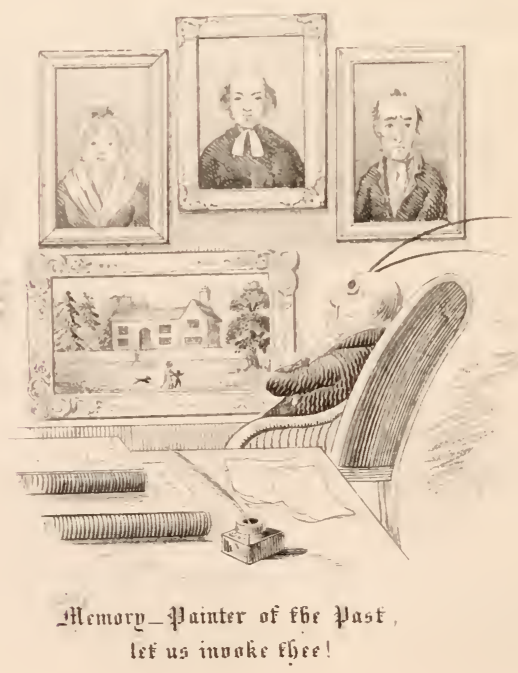




\section{GENERA L I N D EX.}

Page.

Abraxas grossulariata (Magpie Moth), winter caterpillars of . vol. i. 97 Acari, or Mites, parasitic on black beetles and other insects iii. 37,205 parasitic on birds and quadrupeds

iii. 206 parasitic on man

iii. 207

Acherontia Atroyos (Death's-head Moth) . . . . . . ii. 306 Acheta campestris (Field Cricket) . . . . . . . iii. 15 domestica (House Cricket), its characteristics . . . . i. 8 Achetide (Crickets) . . . . . . . . . iii. 15 Acridophagi (Locust-eaters) . . . . . . . . . . i. 159 Acrida viridissima (Large Green Grasshopper) . $\quad$ i. 160, 200 Admiral, the Red, or Alderman Butterfly (Vanessa Atalanta) . . ii. 112 the White, or Camilla Butterfly (Limenitis Camilla) _ . ii. 131 Aeronautic Spiders, their webs, and shooting of their lines . . ii. 127 Ashrea varia (Green Dragon-fly) . . . . . . . ii. 273 Affection in insects and other animals, as apart from instinct . . iii. 90 Affections of insects, maternal and social, and their modes of mutual communication . . . . . . . . . . iii. 348 Agelena labyrinthica (Labyrinthic Spider) . . . . . . i. 133 Aglossa pinguinalis (Tabby Moth) . . . . . . . . i. 278 Agrion, the genus (Dragon-flies) . . . . . . . . . ii. 273 Aids to motion self-wrought by various insects _ . . . . iii. 196 Alderman Butterfly (Vanessa Atalanta) . . . . . . i. 310 caterpillar of . . . . . . . . . . ii. 128 Alucita hexadactyla (Twenty-plume Moth) . . . . . . ii. 320 Anacreon, Ode of, to the Tree-hopper, misnamed Grasshopper . . iii. 2 VOI. III. 
Page.

Ancients, their great observance of Becs

vol. ii. 210

Animals, the lower, probability of their continued existence

iii. 354 opinions of Southey and Lamartine

iii. 355

Anobium, the genus, Wood-boring Beetles

iii. 138 pertinax and A. tessellatum

iii. 138

Antennæ, as organs of hearing

i. 199,213

of the Rose-chafer

ii. 80

of the Stag Beetle

ii. 83

of twilight and nocturnal Moths

ii. 212

Anthrenus, Beetles of the genus, living (as larva) upon desiceated remains

iii. 124

Anthophora retusa (a Mason Bec).

iii. 313

Ant-Lion (Formica Leo), story founded on its habits

iii. 220

description of its grub, or larva, and the pitfall it construets

iii. 2.13

pupa, eocoon, and emergement

iii. 245

Ant, female, her practice of removing her own wings

ii. 189

Ants, adaptation of their varied forms

i. 125

- derotion to their young

i. 124

economy and government of

i. 124

errors coneerning

i. 86

i. 90

habitations of

i. 123

slare-making, their practice of

i. 122

wars of

i. 123

weapons and acid of

i. 87,88

winter habits and eonneetion with aphicles

ii. 80

Apatura, Butterflies of the genus

ii. 129

Iris (Purple Emperor Butterfly)

i. 308 , ii. 112,129

Aphides (Plant-lice)

i. 172

connection with Ants

i. 182

enemies of .

i. 181

generation of

i. 186

- habits of .

i. 185

importanee of

i. 189

Aphis of the Apple (A. lanigera)

i. 183

of the Currant ( $A$. Ribes)

i. 178

of the Elder (A. sambucaria)

i. 183 of the Hop (A. Humuli) 
Page.

Aphis of the Oak (A. Quercus) vol. i. 91

- of the Poplar (Eriosoma Populi) .

i. 183

i. 175

i. 251

Apis mellifica (Honey-bee) .

ii. 113

April Miselia (the Sun-hating Moth)

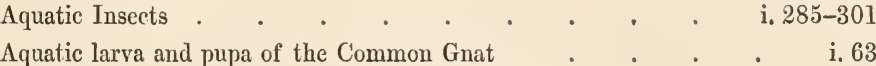

Aranea domestica (House Spider) . . . . . . . . i. 136

Arctia Caja (Great Tiger Moth) . . . . . . . ii.315

- caterpillar of . . . . . . . . . . . . . . i. 99

Argus Butterfly . . . . . . . . . . . i. 310,316

Argus, or Alexis, Blue Butterfly (Polyommatus Alexis) . . . . ii. 135

Argynnis, Butterflies of the genus . . . . . . . . ii. 125

Argynnis Aglaia (Dark Green Fritillary) . . . . ii. 125

— Paphia (Silver-washed Fritillary) . . . . . . ii. 125

Argyroneta aquatica (Diving Water Spider) . . . . i. 137, iii. 308

Atmospheric changes, sensibility of Insects to . . . . . . i. 205

Awl, or Piercer, of female Gall-fly, used in depositing eggs _ iii. 329

Bark-builders, caterpillars of Pyralis Strigulalis _ _ . . . . $\quad$ ii. 99

Banyan Hospital, near Surat, for animals, including insects . iii. 204

— Bishop Heber's account of . . . . . . . . iii. 218

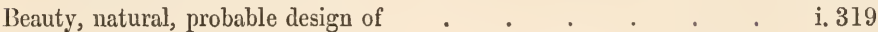

Bedeguar, or Moss-gall of the Rose . . . . . . . ii. 67

Bee Clear-wing Moth (Sesia apiformis) . . . . . ii. 321

Bee Hawk-moth (Sesia fusiformis) . . . . . . . ii. 321

Bee-hives, American . . . . . . . . . ii. 212

— of glass . . . . . . . . . . . . ii. 200

— stores of treasure, natural and moral . . . . . . ii. 194

Bee Tiger: Death's-head Moth, why so ealled . . . . . ii. 307

Bees, boiled, anecdote of . $\quad . \quad$. $\quad . \quad$. . . . ii. 164

- building, mode of . . . . . . . . . . ii. 206

- cleanliness of . . . . . . . . . . ii. 205

- division of labour among . . . . . . . . ii. 207

— drones . . . . . . . . . . i. 254

—_flight, unerring . . . . . . . . . . . ii. 199

- hive, economy of . . . . . . . . i. . . . . . . . . .

- hive, interior of . . . . . . . . . i. 257 
Page.

Bees, nymphs of .

vol. i. 258

- - proceedings of, on returning to hive

ii. 200 queen

i. 252

i. 261

i. 257

i. 194

iii. 85,319

iii. $\delta 8,313$

iii. 88

iii. 80

i. 156

i. 199,205

i. 253

Beetles, aquatic

i. 293,299

_- dung-resorting and carrion-fceding, uses of, as scavengers

iii. 124

ii. 30

- final transformations of

iii. 271

lirds that prey on insects

i. 169

Blight, the white, on apple-trees

i. 183

Blight-insects, and errors conecrning

i. 173

- - origiu and propagation of

i. 173

Blood-worms (larræ of Chironomus plumosus)

i. 71

Blue Butterflics (genus Polyommatus)

ii. 134 , iii. 265

- eaterpillars of

ii. 135

Boat of eggs constructed by the female Gnat . . . . . . . i. 62

Bomby. Mori (Silkworm) . . . . . . . . . i. 162

Book of Nature a book of symbols . . . . . . ii. 292

Book of Nature, how to read it . . . . . . . . i. 22

Books on Entomology

i. $4,15,17,21,22,27$

Borer, or Brad-awl, of the common Ichneumon

iii. 329

Bostrichus typographicus (Printer Beetle)

ii. 163

Bougeaut, Father, speculation on brute existence

i. 291

Bracelet of Eggs

i. 95

Breathing-organs of Insects .

i. 204

Brimstone Butterfy (Gonopterix Rhamni)

i. 107,316 , ii. 119 caterpillar of

ii. 120

- its resemblance to a floral product

ii. 120

Brimstone Moth (Rumia cratagata)

ii. 316 
Brimstone Moth, caterpillar of, "Walking Branch"

Page.

Brown-tail Moth, caterpillar of

vol. ii. 286

Bryant, lines by, on the Mosquito

i. 269

Buff-tip Moth (Pygara Bucephala), caterpillar of .

ii. 103

Bug and Bugbear

iii. 210

Bug-catcher, the Nasked (Reduvius personatus)

iii. 211

Bugs of Field aud Garden, or Plant-bugs (Pentatomida, \&rc.)

iii. 212

- Blue, of China, and of England (Pentatoma carulea)

iii. 214

Buprestidee and Chrysomelidee

Bur-dock, seed-heads of, appropriated by Moth Caterpillars

iii. 267

Burnished-brass Moth .

ii. 238

ii. 316

Burying Beetle (Necrophorus vespillo), description of

iii. 118

_ its practice of interring animal remains .

iii. 118

Butler, author of a 'Book of Bees'

ii. 209,224

Butterflies .

i. 302,320

analogies and relations of, with flowers

i. 306

ii. 130,137

ii. $124,130,133$

— colour in opposite sexes, those differing in

i. 311

- emergement of, from the puparium

ii. 25

- exes of

i. 195

Linnean nomenclature of

i. 317

migrations of

i. 315

wings of

i. 317

winter and early spring

ii. 119 winter survivors among

i. 105

Cabbage Butterfly (Pontia Brassica)

ii. 123

- caterpillar of

i. 272, ii. 123

caterpillar of, a prey to the Ichueumon .

iii. 29

- chrysalis of

ii. 25

Calosoma sycophanta and C.inquisitor

ii. 107

Cantharides (Spanish Flies) .

i. 161

Capabilities of Insects as compared with those of the higher animals .

iii. 352

Carabi (Predatory Beetles)

ii. 106,107

Carabus aterrimus and C. nitens .

ii. 115

Cardinal Beetle (Pyrochroa coccinea)

ii. 86,115

Carottier le grand, caterpillar so called

ii. 122 
Carpenter Ants

Page.

— caterpillars

vol. ii. 105,116

Carpentry of Ants

ii. 313

iii. 322

iii. 319

of the Violet Bee (Xylocopa violacea)

iii. 320

of Solitary Wasps

iii. 318

Carving, or Seulpture, of inseet eggrs, elytra of beetles, \&e.

iii. 252

Case or Caddis 1'lies (Phryganea)

ii. 55

Cassida equestris (Green Tortoise Beetle)

ii. 85

Caterpillars attaeked by Iehueumons .

iii. 29

ii. 34 easting of their skins

ii. 163 frozen

i. 271 , ii. 113

leaf-rolling .

ii. 103

"Loopers"

iii. 181

ii. 103

ii. 110

ii. 108 "Monsters"

ii. 99

oak-bark building and tent-making

iii. 259,324

ii. 88

rearing of .

ii. 138

social

i. 101,265 , ii. 101

"Walking Branehes" .

ii. 104

Cecidomyia (Gall Guat)

ii. 69

Tritici (Wheat-fly), deseription of, and its depredations

iii. 107

Ceramby. moschatus (Musk Beetle)

ii. 81

Cerura vinula (Puss Moth) .

i. 103

Cerculionida (Weevils)

ii. 85

foreign and domestie

iii. 266,267

Cetonia aurata (Rose-ehafer)

ii. 72

Chironomus plumosus (imago of the Blood-worm)

i. 71

Chrysalides

ii. 102

ii. 25

ii. 103

iii. 31

Chrysis ignita (Golden Wasp, or Ruby-tail Fly)

iii. 34

Chrysomelide (Golden Apple Beetles)

ii. 85 
Page.

Chrysopa perla (Lace-wing Fly)

vol. i. 181, ii. 278,282

Churchyard Beetle (Blaps mortisaga), its habits

iii. 120

_ remarkable blackness of

iii. 121

— strange vitality and longevity of

iii. 122

Cicada Anglica .

iii. 329

aurita (Gold-green Cicada of the Oak)

ii. 115

_ spumaria (Cuckoo-spit Frog-hopper)

iii. 10

— the classic, a rare British insect

iii. 10

_ (Tree-hopper), celebrated by the ancients for its music

ii. 215

- instrument of sound in

ii. 219

- ovipositor of female

iii. 328

Click-beetles (Elaterida), of the same family as Fire-flies .

iii. 166

Climbing Fish (Perca scandens) and climbing Chrysalis of Goat Moth

iii. 189

Clisiocampa neustria (Lackey Moth)

i. 95,273

Clothes Moth (Tinea pellionella)

i. 275

- caterpillar of

i. 276

Coccinella (Ladybird)

ii. 1

Coccus of the Hawthorn, her eggs protected by her dead body . o iii. 93 of the Vine, and her cotton-covered eggs

iii. 93

Cochineal Insect (Coccus)

i. 165

Cockroaches (Blattide)

i. 305

Cocoon of caterpillars .

iii. 323 of Emperor Moth

ii. 233

ii. 29 of Great Goat Moth

iii. 324

— of Hawthorn Saw-fly .

i. 103 , ii. 29

_ of Silkworm

ii. 29 of Tiger Moth

i. 100

Collectors of insects, disappointments to, through the agency of parasitic insects .

iii. 32

Colours, opposite, made to harmonize in natural objects

iii. 251

Coming out, or development, of insect forms .

ii. 22

Compound eyes of insects

i. 195

Convolvulus Hawk Moth (Sphinx Convolvuli)

ii. 304,30 ร

Copper Butterflies (genus Lycana)

ii. 133

Copper Butterfly, the common, (Iycana Phleas)

ii. 134

Copris lunaris (Dung Beetle), singular horn of

iii. 122

Cossus ligniperda (Great Goat Moth)

ii. 313 
Page.

Cossus ligniperda, caterpillar of . . . . . . . . vol. ii. 231

Corydon Blue Butterfly (Polyommatus Corydon) . . . . . ii. 135

Cotocala nupta (Red Underwing Moth) . . . . . . . . ii. 316

Crane-fly, common (Tipula oleracea), use and purpose of its long legs iii. 100

- enemies of . . . . . . . . . . . iii. 100

— larvæ of, injurious to grass . . . . . . . iii. 104

- ovipositor and eggs and pupæ of . . . . . . . . iii. 106

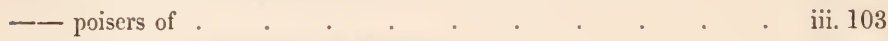

Crepuseular, or Twilight-flying, Moths . . . . . . . ii. 303

Cricket, the Field (Acheta campestris), habits of . . . . iii. 15

- kept in eages . . . . . . . . . ii. 217

- $\ldots$ the House (Acheta domestica), as a symbol . . . . iii. 20

Crickets (Achetide), their instruments of sound . . . . ii. 220

Cruelty, remarks on, as eonnected with collecting insects . . i. 24, ii. 170

Ctenophora ornata (species of Crane-fly) . . . . . . iii. 107

Cuekoo-flies, Iehneumons so called . . . . . . . . . iii. 27

Cuckoo-spit Froghopper (Cicada spumaria) . . . ii. 115, iii. 10

- - transformations of . . . . . . . . iii. 11

Culex pipiens (Common Gnat), transformations of . . . . . i. 62

Cultivation of Bees . . . . . . . . . . i. 212

Cupid and Psyche, fable of, its derivation . . . . . . . . ii. 32

Curtis, his remarks on our imperfect knowledge of Nature's productions i. 170

Cynips (Gall insect) of the Oak (C. quercus), and others . . . . ii. 64-69

Cynthia, the genus . . . . . . . . . . . ii. 128

Cynthia Cardui (Painted Lady Butterfly) . . . . i. 315, ii. 129

Darwin, Dr., his anecdote of a Wasp and dead Fly . . . . ii. 226

- Kirby's inference from above anecdote . . . . . . . $\quad$ iii. 346

—_ Day-flies (Ephemerce) . . . . . . . . ii. 47

Deadness of perception to the beanty and wonder of ereation . . i. 94

Death of Nature, life in the : . . . . . . . . . 93-117

Death, power of resistance to, in insects . . . . . . ii. 161

Death's-head Moth (Acherontia Atropos) . . . . . . ii. 306

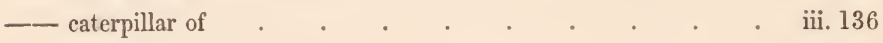

— description of . $\quad . \quad$. $\quad . \quad . \quad . \quad . \quad$ iii. 131

- proboscis and antennæ of . . . . . . . iii. 134

- robber of bee-hives . . . . . . . . . iii. 134

- season of its appearance. . . . . . . . . . . iii. 133 
Death's-head Moth, shroud of

vol. iii. 133

sound of, and organ which produces it

iii. 132

- superstitions terror, an object of

iii. 129,134

Deathwateh Beetles (genus Anobium)

iii. 138

Deathwateh Woodlouse (Termes pulsatoria)

iii. 139

i. 20

De Geer, history of his work .

ii. 115

Dermestes (a beetle of the Oak)

iii. 123

Dermestidae (beetles living on dry bones)

i. 289,301

Destructiveness, mutual, as a law of Creation, thoughts on

ii. 106

Devil's Coach-horses, Rove-beetles (Staphylinida) so ealled

ii. 316

Diving-bell, model of, in the cell of a Water Spider

i. $137,138,139$

Division of labour among Bees

ii. 207

Dock-leaves, larvæ of flies common on

i. 33

ii. 87

Domestication, some inseets eligible for .

iii. 116

Dor, or Cloek-beetle (Geotrupes stercorarius) .

i. 298

Dragon-fly (Eshna varia)

ii. 275

i. 296

Dyes, insects used as

i. 165

Earwig, the female, her practice of sitting on her eggs and brooding

her young . . . . . . . . . . iii. 92

Eggg-bearing Water Scorpion _ . . . . . . . iii. 93

Eggs of Inseets, their beauty of form, colouring, and earving i. 29, iii. 252

— resistance of frost, their capability of . . . . . $\quad$ i. 97

Elater noctilucus (tropic Fire-fly) . . . . . . . iii. 165

Emerald Noth . . . . . . . . . . ii. 316

Emperor Butterfly (Apatura Iris) . . . . . . . ii. 112, 129

Emperor Moth (Saturnia pavonia), and caterpillar of . . . ii. 314 eurious coeoon of . . . . . . . . ii. 233

Entomology, its peculiar merits as a hobby . . . . i. 13, 29, 303

— persecution of the science, and recent progress _ . . . i. 19, 21

— writers on, ancient and modern . . . . i. 4, 15, 17, 21, 27

Epeira diadema (Garden Spider) . . . . . . . . i. 132

Ephemera vulgata (Common May- or Day-fly), deseription of . . ii. 48

— dangers and enemies of, numerous _ . . . . . ii. 49 enjoyments of . . . . . . . . . ii. 51 
Page.

Ephemera vulgata, long-lived aquatic larva, pupa, and imago of vol. i. 12, ii. 51

— fourth development of . . . . . . . . ii. 53

- season, of appearance of various species of . . . . . ii. 55

Ephemere of Nature and of Art contrasted . . . . . . . ii. 46

Eriosoma Populi (Gall-aphis of the Poplar) . . . . . . i. 183

Eristalis tenax (Sewer-fly), Rat-tailed larva of, and its tenacity of life ii. 164

Ermine Moth (Yponomevta padella) . . . . . . i. 270

— caterpillar of . . . . . . . . . . . . 271

Exeavated Habitations of the Jetty Emmet and other Ants . . iii. 322

Experiments of Réaumur and others on the eurtailment of inseet life . iii. 153

Eyes of Insects . . . . . . . . . . . . i. 193

Fable, La Fontaine's, of 'Les Souris et le Chat-huant' . . . iii. 34t

Field-bug, female, practice of conducting her infaut brood . . iii. 93

File and Auger (a compound tool) of the Tree-hopper . . . iii. 328

Fire-flies (Elaterida), description of . . . . . . iii. 165

— their naturalization proposed and possible . . . . iii. 165

Fleas and their performances . . . . . . iii. 214

— various speeies of . . . . . . . . . iii. 217

Flies, House (Musca domestica) . . . . . . . . . . i. 32

— appearance of, on emerging from puparium . . . . . $\quad$ ii. 31

- lines on, by Wordsworth . . . . . . . . . i. 35

— mode of walking, flying, buzzing, feeding . . . . . . i. 37-4l

- strueture, habits, and uses of . . . . . . . . . . i. 36

— poisers, wings, and winglets of . . . . . . . . i. 43

- species of, much resembling the IIouse-fly, common as a larva

on Dock-leares . . . . . . . . . . . . . . . 33

— various species of . . . . . . . . . . . . i. 42

- whenee they come and whither they go . . . . . . i. 33

Flight, against the wind, of Bees, Butterflies, and some Bectles . iii. 186

— rapid, of Dragon-flies . . . . . . . . . . . . iii. 183

— suspensory, of Hawk Moths and Syrphi . . . . . iii. 184

Flowers, their various relations with insects . . . . i. 27, 170, 306

Foreing of insects to maturity . . . . . . . . . i. 308,309

Formic acid . . . . . . . . . i. 123

Formica rufa (Wood Ant) . . . . . . . . i. 87, 90, 122

— rufescens and Formica fusca (Negro Ant) . . . . . i. 122

- flava (Yellow Ant) . . . . . . . . . i. 182

Fritillaries (Butterflies of the genus Argynnis). - . ii. 124, 125, 126 
Fritillaries, Dark-green and Silver-washed (A. Aglaia and A. Paphia) vol. ii. 125 Fulgora (Great Lantern-fly), sound emitted by

Fulgore (Lantern-flies), doubts as to their luminosity

iii. 162

- Donovan's description of those of Hindostan .

iii. 163

their proposed importation from China

iii. 164

Galls, various, and the Insects which produce them .

ii. $60,71,116$

— fanciful speculations about their origin and oceupancy

ii. 62

- their real origin and manner of production

ii. $6+-70$

Gastropacha quercifolia (Oak Lappet Moth) .

ii. 288,318

Geometer Caterpillars of the Magpie Moth

i. 98 of the oak.

ii. 103

ii. 319

Geometrie Spiders and their webs

i. 132

Gerris locustris (a Water-bug)

i. 293

Gilding of Chrysalides and of Moths

iii. 269,270 what produces

iii. 272

Glass Bee hives

ii. 206

Glowworms (Lampyride)

iii. 167

— flying, of Southern Europe (Lucciole)

iii. 167

iii. 170

purpose of the light of, conjeetures about

i. 58

Gnats (Culicidee), aerial danees of .

i. 66

— females, biting

ii. 163

frozen, revival of .

i. 59 males, plumed

i. 72

species of, of origin not aquatic

i. 72

transformations of the common species of

i. 231,313

Goat Moth (Cossus ligniperda) and Carpenter Caterpillars of

i. 267 Gold-tail Moth

i. 265

\section{Gonopterize Rhanen (Rrinstone Butterfy)}

i. 107,316 , ii. 119

Gonopterix Rhamni (Brimstone Butterfly)

i. 126

Gossamer, origin and formation of, and Gossamer Spiders .

i. 274

Grain Moth (Tinea Hordei), and eaterpillar of

ii. 131

Grass and Meadow Butterflies of the genus Hipparchia

iii. 2

Grass- and Tree-hoppers, view of their habits and characteristics

iii. 19

Grasshopper, as a symbol

iii. 15

Carnivorous (Acrida verrucivora).

iii. 13 
Grasshopper, Large Green, its edible quality .

vol. i. 160

Grasshoppers (Gryllide), general habits of

iii. 2

beauty of some exotie species

iii. 15

Gryllida, Locustida, and Achetida, the families, distinctions between

iii. $13,15,17$

Gryllotalpa vulgaris (the Mole Cricket)

iii. $76-79$

Gryllus morbillosus, a Chinese Grasshopper of splendid colour .

iii. 263

Gyrinus natator (Whirlwig Beetle)

i. 196,294

Hairstreak Butterflies (genus Theckla), and Purple Hairstreak (T. quercus) .

ii. 133

onisciform eaterpillar of

ii. 133

Hammocks, woven, or winter nests of the Brown- aud the Gold-tail Moth eaterpillars

ii. 100

Happincss, opposite ideas respecting, among various nations

iii. 1

Harvest Spider (Phalangium)

iii. 293

IIawk Motlss and their Caterpillars

ii. $303-312$

IIearing, sense of, in Insects

i. 199

IIeath and Ringlet Butterflies, of the genus Hipparchia

ii. 132

Ilemerobius (Lace-wing Fly)

ii. 254,278

IIepialus IIumuli (Ghost Moth)

i. 293

Iferbert, George, lines by, on Spring Flowers .

iii. 151

IIespericle (Skipper Butterflics)

ii. 136

Hipparchia, the genus (Meadow Butterflies)

ii. 131

IIipparchia Janira (Meadow Brown Butterfly)

ii. 132

IIisteride, Leaping Beetles, called also Pill and Horse-bean Beetles

iii. 123

IIoney, poisonous

i. 207

Honcycomb, node of its coustruction

ii. 206

Honey-dew, its nature .

i. 179

Horse-bean Beetles (IIisteride)

iii. 123

Huber, Francis, the historian of Bees, sketch of

ii. 195

Huber, the younger, the historian of Ants, observations by

ii. 189

II uman mind, as symbolized by inseet phenomena

ii. 299

IIumble-bees, method of extracting honey from the Bean, Suapdragon, and other tubular flowers

iii. 347

Humming-bird Hawk Moth (Jiacroglossa stellatarum) . . . ii. 305

Hybernation of Insects

i. 22,93

Hydrometa stagnorum (Water Measure:)

i. 293 
- from the eggs of Butterflies and apples of Gall-flies

iii. 36 minute species of 
Page.

Lace-wing Fly, the Green Golden-cyed

vol. ii. 254 aphidivorous larva of

i. 170,181, ii. 281

— pupa, cocoon, and singular eggs of

ii. 280,282

Lackey Moth, curious eggs of

gay caterpillars of .

i. 273

Ladybird (Coccinella) .

ii. $]$

_ feeder on Aphides

i. 170,180

usefulness, transformations, liybernation, and varieties of .

ii. $3-9$

Lady of the Woods, or Orange-tip Butterfly (Pontia Cardamines)

ii. 124

Lamartine, Alphonse de, lines by, on the insect millions and their

music

ii. 226

- on the melody of insect ehoirs

iii. 142

translation of an address by, to his favourite $\log$

iii. 356

Lampyride (Glowworms)

iii. $167-174$

Lampyris Italica, also Lucciola (Flying Glowworm)

iii. 167

- appearance of, and superstitions relating to

iii. 168

noctiluca (Common Glowworm)

iii. 169

Lantern-flies (Fulgore)

iii. 162

Lappet, the Oak, Moth (Gastropacha quercifolia), only " walking leaf"

insect of Britain

ii. 289,318

caterpillar of

ii. 318

Leif-buttons of the Oak

ii. 244

Lcaf-cutter, or Upholsterer Bees, and their ingenious operations

iii. 82

Leaf-cutting Caterpillars

ii. 243

Leaf-hammocks .

ii. 245

Leaf Inscets, or "Walking Leaves" of the tropics

ii. 285

Leaf-mining Caterpillars

ii. 246

exquisite Moths from

ii. 317 , iii. 270

Lcaf-nests of Spiders

i. 137

Leaf-rolling Caterpillars

i. 271,272 , ii. 240

Leaf Tassels

ii. 245

Libellula (Dragon-fly), masked larva of .

i. 296

Lice of Plants, or Aphides

i. $172-189$

Lice, tributary, of Mexico and Peru

iii. 209

Light, colouring properties of, their effect and value

iii. 249

__ emitted by Insects, its supposed nature and properties

iii. 172

Lime Hawk Moth (Sinerinthus Tilia)

ii. 309

Limenitis Camilla (White Admiral Butterfly).

ii. 131 
Page.

Lobster Moth (Stauropus Fagi)

vol. ii. 111

_ singular caterpillar of .

ii. 110

Locusta migratoria (Migratory Locust) .

iii. 17

Locustide (Locusts) native and foreign .

iii. 17,18

Locust, as food . . . . . . . . . . . . . .

— as a symbol . . . . . . . . . . iii. 21-23

Longlegs, Father, the common Tipula, or Crane-fly, and its other

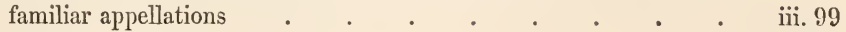

Long livers among perfect insects . . . . . . . . iii. 148

Loopers, caterpillars so called . . . . . . . ii. 103, 319

Lozotania rosana (Leaf-rolling Caterpillar of the Rose) . . i. 271

Lucanus cervus (Stag Beetle) . . . . . . . ii. 83

Lucciole, le (Flying Glowworms of Southern Europe) . . ii. 140-159

Luminous Eyes of various Moths . . . . . . . iii. 174

Luminous Insects . . . . . . . . . . iii. 160

— considered as symbols . . . . . . . . . . iii. 161

- their existence noticed by the ancients . . . . . iii. 161

- their harmlessness and uses . . . . . . iii. 175-177

Luminous or Electric Centipede (Scolopendra electrica) . . . iii. 174

Lycana (the genus), Copper Butterflies . . . . . . ii. 133

— Phleas (Common Copper Butterfly) . . . i. 206, 312, ii. 134

Macroglossa stellatarum (Humming-bird Hawk Moth) . . . ii. 305

Magpie Moth (Abraxas grossulariata), Geometer Caterpillars of . i. 98

- caterpillars and chrysalides of, attacked by Ichneumons . . . iii. 31

Mammestra Brassica (Cabbage Moth) . . . . . i. 272

Man, influence of, on the lower orders of creation . . . . iii. 351-353

Mandibles or jaws of Wasps, uses of, as a compound tool . . . . iii. 327

Mantis, resemblance of, to vegetable substances . . . . . ii. 285

Mask, singular, of the Dragon-fly Larva o . . . . . $\quad$ i. 98

Mason Spider, hinged nest of . . . . . . . . i.137

- Wasp, nest of, invaded by Ichneumons . . . . . . iii. 28

Masonry of Caterpillars . . . . . . . . . iii. 317

—— of solitary Bees and of Ants . . . . . . . iii. 313, 315

— of solitary Wasps . . . . . . . . . . . iii. 311

May-fly (Ephemera) . . . . . . . . . ii. 48

Neadow Brown Butterfly (Hipparchia Janira) . . . . ii. 132

Measurers, caterpillars so called . . . . . . . ii. 103 
Page.

Mechanism of insect sounds .

vol. ii. 219-222

Melitaa, the genus, (Fritillary Butterflies)

i. 318

Meloe Chicorei (a Blister Beetle) .

i. 161

Menagerie, proposed, for insects

i. 26

Merian, Madame, her description of the Lantern-fly of Surinam

iii. 162 her work on the insects of Surinam

i. 98

Migrations of Butterflies

i. 315

"Miracles of Nature," Moths from Leaf-mining Caterpillars

ii. 317

Miracula insectorum of Linnæus

ii. 164

Mite, Scarlet Satin

i. 166

Mole Cricket, habits, nest, and supposed luminosity of

iii. 76

"Monster" Caterpillar of the Oak

ii. 108

Mosquitos, and lines on, by Bryant

Moths, Caterpillars of, as destruetives

i. 67,68

i. $265-278$

ii. 303

ii. 325

__ disappearance, sleep, and mode of fecding of

ii. 312 nocturnal, or night-flying

ii $319-323$

plumed, wingless, and those having luminous eyes

i. 17

Mouffet, a Father of Entomology .

iii. $178-201$

Morenents, different kinds of, among insects .

_ peculiar to insects, progressive and non-progressive

iii. $192-195$

_ in autumn, preparatory for winter

iii. 196

Blusca domestica (House Fly)

i. $32-43$

Muscide, various species of the family .

i. 33,43

Music of Nature and of insect choirs

ii. $215-227$

Musk Bectle (Ceramlyy moschatus), its beauty and fragrance

ii. 81

Aygale cementuria (Mason Spider)

i. 136

Mysteries of Bee Cities

ii. 208

Natural forms and decorations, as suggestive of artificial

iii. 273

Naturalization, proposed, of some exotic insects

ii. 87

Nature, as suggestive to Art .

iii. 298

Negro Ant (Formica fusca) .

i. 123

Nepa cinerea (Water Scorpion)

i. 295

Nervous System of Insects .

ii. 169

Nests of Solitary Wasps, and their mode of feeding their young iii. 89,343

- summer, of caterpillar of the Ermine Moth .

i. 271 winter, of caterpillars of Brown- and Gold-tail Moth 
Notation of Insect Sounds vol. ii. 223

Notonecta glauca (Common Boat-fly) .

Oak, its insect frequenters, a few among ii. 94-117

Oak Lappet Moth (Gastropacha quercifolia) .

- or instruments of sound, in the Cicada, in the Cricket, in the

Grasshopper, in the Gnat, in Bees, in Beetles

ii. $219-223$

Orgyia antiqua (Vapourer Moth), wingless female of

Ovipositor, or Borer, of the Ichneumon-fly, and its mode of employment iii. 27 Ovipositor of the Gall-fly . . . . . . . . ii. 70

Painting of Caterpillars, of Spiders, of Dragon-flies, of Grasshoppers,

and Plant-bugs . . . . . . . . . . iii. 255-263

- mosaic, of Butterflies, and the enamel of Beetles iii. 264-266

Paper-making of Wasps

iii. 325

Papilio, the genus, as now restricted

ii. 120

Papilio Machaon (Swallow.tail Butterfly)

ii. $120,121,122$

Papilio Ulysses, P. Priamus, and P. Menelaus

i. 317

Parasite Ichneumons

Parasites, general liability to, amongst Insects

iii. 36 in Chrysalides .

Pictures, emerging, presented by the gradual coming out of colours in 
Page.

Pill Bectles (Histerida) . . . . . . . . . . vol. iii. 123

Pimpla manifestator (a common species of Ichneumon) . iii. 28, 329

Pismires, or Wood Ants, and their habitations _ . . . . i.90,91

Plants and Insects, their external and other resemblance . . ii. 294-296

— and Insects, their relation of mutual uses _ . . i. 170, 315, ii. 299

Plebeii Urbicoli, Linnean division of Butterflies so ealled _ ii. 137

Plumed Moths: Large White (Pterophoms pentadactylus) and Twenty-

Plnme (Alucita hexadactyla) . . . . . . ii. 319,320

Poisers of the Fly and other Diptera . . . . . . . i.43

Polyommatus (the genus), Blue Butterflies, and eaterpillars of . i. 206, ii. 134

- Argus, (Common Blue Butterfly), and P. Corydon . i. 310,311,316

Polytechnic Institution, insect similitudes of some of the objects there

cxhibited . . . . . . . iii. 297, 301-310

Pontia (the genus), Garden and White Butterflies . . . ii. 122-124

- Brassica (Cabbage Butterfly) . . . . i. 104, 198, 312, ii. 123

— Cardamines (Orange-tip Butterfly) . . . . i.316, ii. 124

Poplar Hawk Moth (Smerinthus Populi) . . . . . ii. 309

Poppy Bee (Osmia Papaveris), her nest and mode of its construction iii, 82, 83

Porthesia auriflua (Brown-tail Moth), caterpillar of . . . ii. 101

Porthesia chrysorrhea (Gold-tail Moth) and eaterpillar of . i. 101, 265-269

Prejudices against Insects . . . . . . . . ii. 90,92

Progression of Legless Larvæ, and leaping of the same . . iii. 187,188

Printer Beetle (Bostrichus typngraphicus), vitality of . . . ii. 163

Privet Hawk Moth (Sphin.x Ligustri), and eaterpillar of . . . ii. 310

Purple Emperor Butterfly (Apatura Iris) • . . . ii. 112, 129

Puss Moth, Cocoon and Chrysalis of . . . . . . . . i. 103

Pygara Bucephala (Buff-tip Moth) . . . . . . . ii. 290

Pyrgus Malve (Grizzled Skipper) . . . . . . . . ii. 138

Pyrochroa coccinea (Cardinal Beetle) . . . . . . . ii. 86

Queen Bee, her maternal characteristics . . . . . . . iii. 96

Rat-tailed Larva and Pupa of Sewrer-fly (Eristalis tenax), their tenacity

of life . . . . . . . . . . . ii. 164

Reasonable aetions of Insects-such as seem directed by reason iii. 341, 346, 347

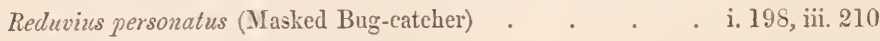

Resemblances between Plants and Inseets . . . . . ii. 294

Rose-chafer (Cetonia aurata), its beauty and pleasing habits . . ii. 73 
Rose-chafer, its transformations . . . . . . . . . vol. ii. 79

"Rose Leaf-cutter" Bee and her nest . . . . . . . iii. 85

Rose Willow, Gall on the Willow so called . . . . . . . . ii. 69

Saw, compound, of the female Saw-fly, and its purpose . . . iii. 327

Saw-flies (Tenthredinide), and pseudo-caterpillars of . . . iii. 327

Saw-fly, the Hawthorn, and curious cocoon of . . . . . . iii. 323

Saturnia pavonia (Emperor Moth) . . . . . . ii. 233

Scarabaus sacer, or Sacred Beetle, and its symbolic attributes iii. 111, 114-116

Scarabaus, or Dung Beetle, its habits symbolic of the sordid . . iii.114

Scorpion-fly (Panorpa communis), its boldness and bcauty . . ii. 277

Sculpture, natural, in Beetles (Histeride), and other insects . iii. 123, 254

in insect eggs . . . . . . . . . . iii. 252

Senses, organs of, in insects . . . . . . . . . . i. 195-209

Sensibility, amount of, in insects . . . . . . . . . . ii. 169

Sholl, John, and his American Bee-hives . . . . . ii. 211

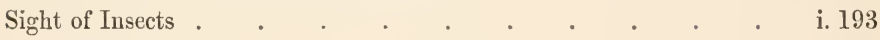

Silk and Silkworms . . . . . . . . . . . 1. 161

Size, augmentation of, sufficient to make insects formidable : imagina-

tive sketch suggested by this idea . . . . . . ii. 252

- wonderful disproportion of, betwixt the Imago of the Lace-wing

Fly and the puparium which encloses it . . . . . ii. 282

Skippers, family of Butterflies (Hesperide) so called _ . . . ii. 136

Smell, sense of, in insects . . . . . . . i. 202, 203, 204

Smerinthus Tilice (Lime Hawk Moth) . . . . . . ii. 308

Souls, transmigration of, Rabbinical notions on . . . . . i. 291

Sounds emitted by iusects, and mechanism of $\quad$. . i. 201, ii. 215, 219

Sphingida, Sphinxes, or Hawk Moths . . . . . ii. 303-312

Spiders, description of species of . $\quad . \quad$. $\quad . \quad$. $\quad$. $\quad$ i. 128-139

- elormous, at Hampton Court . . . . . . . . iii. 288

- maternal affection of . . . . . . . . . . iii. 94, 286

- perseverance, neatness, and ingenuity of . . . . iii. 287, 291, 293

— resemblances of, to destructive animals . . . . . . . iii. 276

- resemblances of, to Men, Beasts of rapine, Birds, Fishes, and

Reptiles . . . . . . . . . iii. 277-286

— sight of . . . . . . . . . . . . . . . . . 292

- superstitious concerning . . . . . . . . . iii. 288

— weather, interpretation of, by their movements . . . . iii. 291 
Page.

Spring, a walk in vol. i. 285

Spring, its banquet to the senses . . . . . . . i. 215

Springs, internal, of insect and other animal activities-their compound nature.

iii. 335

Stag Bectle (Lucanus cervus), description of, and habits . . . . ii. 83

Sting of the Bee, its structure . . . . . . . . iii. 330

- or Piereer, of the Gnat . . . . . . . . . iii. 331

"Stone Masons," Moth caterpillars so called . . . . . ii. 230

Superstition in decline . . . . . . . . . . . iii. 127, 141

- ascendancy of, in the days of Réaumur . . . . . . . . iii. 135

Swallow-tail Butterfly . . . . . . . . . . ii. 120

Swallow-tail Moth (Ourapterix sambucaria), resemblance of its wings

to flower-petals . . . . . . . . . . ii. 288,319

Swammerdam, his apostrophe on the works of God . . . . . i. 18

- his sympathetic description of May-fly miseries . . . ii. 50

Swimming of Aquatic Beetles . . . . . . . . . iii. 187

Symbolic teachings from the Book of Nature . $\quad$. ii. $32,57,229,250,301$

Syrphus grubs, their usefulness in gardens . . . . . i.170, 181

Taste in Insects . . . . . . . . . . . . 206-209

Tegmina, or Wing-cases, of Locustida . . . . . . . . iii. 18

Tell-tales, Gnats so ealled . . . . . . . . . . i. 58

Tenthredinide (Saw-flies), family of . . . . . . . . iii. 328

Tent-makers, moth caterpillars so called, and their structures . . ii. 234

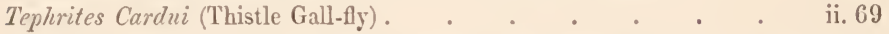

Tettix and Cicada (Greek and Latiu names for the Tree-hopper). ii. 215, iii. 2

Tetragnatha extensa (Long-bodied Spider) . . . . . . i. 132

Thecla (the genus), Hairstreak Butterflies . . . . . ii. 133

Thistle, Insects which frequent . . . . . . i. 315,316

Tiger Bectle (Cicindela) . . . . . . . . . iii. 179, 268

— fieree and singular grub of . . . . . . . . . . . . . . . . 246

Tiger Moth (Arctia Caja), and caterpillar of . . . . . . ii. 315

Tinece, family of moths so ealled . . . . . . i. 274-278

Tinea Hordei (Grain Moth) . . . . . . . . i. 275

- pellionella (Clothes Moth) . . . . . . . . i. 275

Tineide, tent-making and other moth caterpillars of the family ii. 100, 235

Tipule, and long-legged Gnats, various species of . . . . i. 58, iii. 108

Tools of Insects . . . . . . . . . . iii. 302, 327 
Page.

Tortoise Beetle, Green, of the thistle, (Cassida equestris) vol. ii. 85

Tortoiseshell Butterflies, small, of the nettle (Vanessa Urtica), and

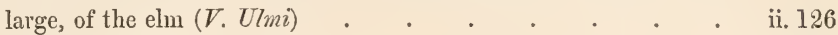

— transformations and emergement of, from their chrysalides . ii. 27

Tortrix viridana (Green Oak Moth) and its leaf-rolling caterpillar ii. 241

Touch, sense of, in Insects . . . . . . . . . i. 205

Transformation, Insect, a series of developments . . . . . i. 93

- incomplete, in the orders Hemiptera, Orthoptera, and others . iii. 12

Tree-hopper, misnamed Grasshopper, of the ancients . . . ii. 215

Tree-hoppers (Cicade), general habits of . . . . . . iii. 2-9

Turner, Sharon, his opinion of the "judging mind" of insects . . iii. 341

— remarks of, on the maternal affection exhibited by insects . . iii. 95

Uses of Insects . . . . . . . . . . . . . 154-171

Tanessa (the genus), Fan-winged Butterflies . . . - ii. 126, 128

- Atalanta (Alderman Butterfly) . . . . . . . i. 310

- Io (Peacock Butterfly) . . . . . . i. 107, ii, 127

— Urtice (Tortoiseshell Butterfly) . . . . . . i. 105, ii. 126

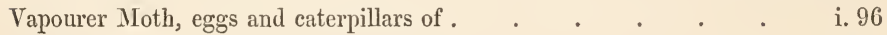

Vegetable parasites attached to insect bodies . . . . . . . iii. 38

Velia rivulorum (a Water Bug) . . . . . . . . i. 293

Vermin, insect, tradition concerning its origin . . . . . iii. 203

Vespa vulgaris (Common Wasp) . . . . . . . . i. 214-231

Vitality among insects, its inequality of duration more apparent than

real . . . . . . . . iii. 150

- obstinate, of insects . . . . . . . ii. 160-168

Wasp, the Golden (Chrysis ignita), parasitic attacks of, on the nests of solitary bees . . . . . . . . . . iii. 34

Wasps $($ Vespide $)$. . . . . . . . . . . i. 216-231

autumnal destruction of . . . . . . . . i. 230

- male and neuter, their characteristics . . . . 1. 222-226

- mode of colonization of . . . . . . . . . . . i. 219

- nests of, their material and structure . . . . . . i. 227

— social, paper-making of . . . . . . . iii. 325

_ solitary, "Masons" among . . . . . . iii. 89, 310-312

— solitary, "Carpenters" among . . . . . . . iij. 89, 318 
Wasps, solitary, practice among, of provisioning their nests

Page.

Walking Leaf and Walking Braneh Insects

vol. iii. 89,343

Walking of Beetles and Butterflies

ii. $284,287,289$ of Caterpillars

iii. 179

iii. 180

— of Iusects (not properly so called) with many legs

iii. 182

- of aquatic inseets under water

iii. 191

Water Beetle (Hydrophilus) . . . . . . . . . . i. 299

Water Boatman . . . . . . . . . . i. 294

Water Bugs and Water Measurer (IHydrometa stagnomum) • . i. 293

Water Insects . . . . . . . . . i. 288-301

Water, purified by insects . . . . . . . . . . . 169

Water Scorpion . . . . . . . . . . . . . . . . . . . . . .

Wax, and its uses . . . . . . . . . . . . i. 167

— its original material and mode of fabrication . . . . ii. 202

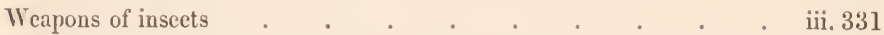

Weaving of Caterpillars, and their apparatus for . . . . iii. 323

— of Spiders, and their apparatus for _. . . . . . iii. 324

Weevils (Curculionide), Wood-feeding, and others . . . . ii. 85, iii. 149

Whirlwig Bectle (Gyrinus natator) . . . . . . . i. 293

— eyes of . . . . . . . . . . . . . 196

Willows, Old, eabinets of treasure to the Entomologist . . i. 102, 286

Wings and Winglets of the Fly . . . . . . . i. 43

Wings of the Butterfly . . . . . . . . i. 318,319

Winter, a walk in . . . . . . . . i. 93-107 Butterflies in . . . . . . . i. . . . . . . . .

Wool of pubescent plants, as employed by Solitary Bees . . . iii. 88

Workers amoug Social Bees and Wasps, affection in, for the young of

their communities . . . . . . . . . iii. 95

Xylocopa violacea (Violet Carpenter Bee) . . . . . iii. 320

Yponomeuta padella (Ernine Moth), nests, caterpillars, and chrysalides of i. 271 







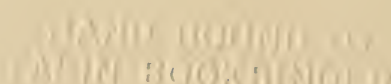



